Universidad Nacional de La Plata

Facultad de Humanidades y Ciencias de la Educación

Secretaría de Posgrado

Doctorado en Filosofía

\title{
Las artimañas de la moda: hacia un análisis del disciplinamiento del vestido
}

Tesis para optar por el grado de Doctor en Filosofía

Doctorando: Camilo Retana (Universidad de Costa Rica)

Directora: Dra. María Luisa Femenías (UNLP-UBA)

Codirectora: Dra. Laura Gioscia (Universidad de la República)

La Plata, 22 de octubre del 2013 


\section{Resumen}

La presente investigación busca problematizar desde un punto de vista filosófico el asunto de la moda. A partir de la premisa de que los fenómenos culturales no son independientes de los saberes y discursos que los recortan y dotan de sentido, el trabajo considera, en primera instancia, la forma en que la moda emerge como problema de estudio. Dado, sin embargo, que los discursos sobre la moda se trenzan de manera densa y compleja con prácticas sociales, la investigación examina en un segundo momento la forma en que unos y otras se articulan y soportan, produciendo complejos dispositivos (o "artimañas") cuyos efectos se caracterizan por domeñar el cuerpo. Desde esa perspectiva, la moda se presenta como un enclave a partir del cual se producen distintas prácticas de poder en torno al cuerpo vestido. Así, las prendas aparecen teorizadas como dispositivos de disciplinamiento corporal, al tiempo que como herramientas de gestión de la vida social. Por último, tomando en cuenta que, como lo indican, entre otros, Michel Foucault y Judith Butler, las normas no alcanzan a conformar de manera acabada a los sujetos y los cuerpos, la tesis discute en un tercer momento las posibilidades del estilo, entendido como forma de desacato crítico de las normas corporales promovidas por la moda. Se trata, en síntesis, de realizar una genealogía de la moda, si por genealogía se entiende, con Foucault, la labor crítica dirigida a mostrar de qué manera las supuestas "verdades" (en este caso las "verdades" del cuerpo) son en realidad el resultado de una serie de dispositivos que se dedican a producirlas.

Palabras clave: cuerpo, moda, disciplinamiento, poder, estilo. 


\section{Índice}

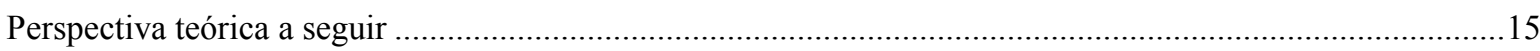

El recorrido del texto

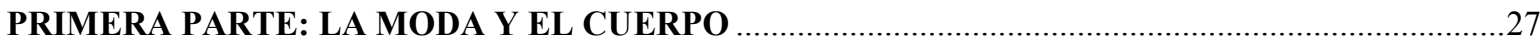

CAPÍTULO 1. La conformación de una episteme: las teorías sobre la moda y la centralidad del asunto de

la difusión

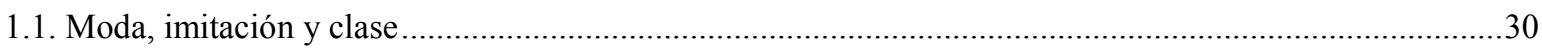

1.2. Detractores y continuadores: los derroteros de la herencia conceptual de Veblen y Simmel .....................34

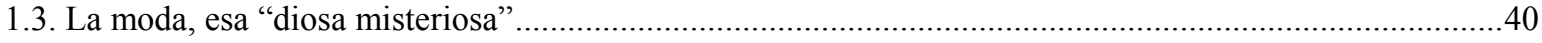

1.4. El estructuralismo y la "máquina de hacer moda" .......................................................................................

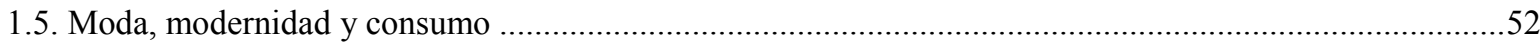

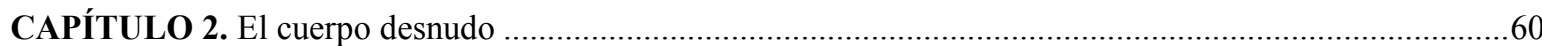

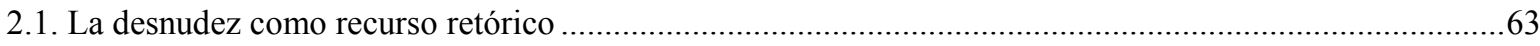

2.2. La extensión cultural de las metáforas biológicas y bélicas ......................................................................65

2.3. Las metáforas biológicas y la moda: especies, luchas y vestidos .............................................................71

2.4. El imposible cuerpo desnudo: las críticas a la visión psicoanalítica y anatomobiológica del cuerpo..........78

2.5. El cuerpo desnudo como consecuencia del cuerpo vestido: hacia un análisis de la moda como

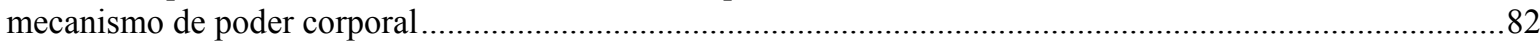

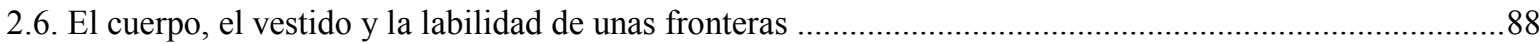

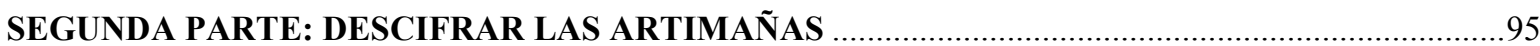

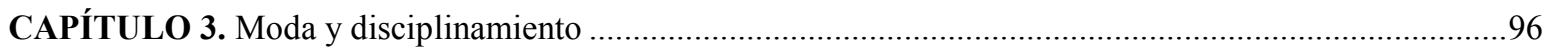

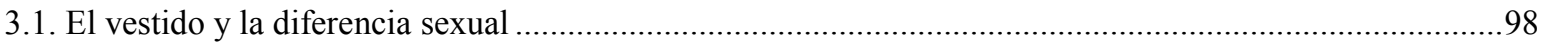


3.2. Las disciplinas allende la cárcel decimonónica: hacia un análisis de la moda como dispositivo disciplinario

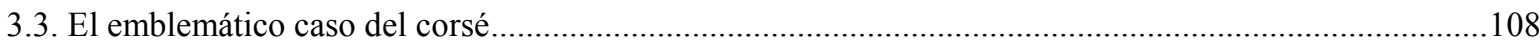

3.4. La estrategia de la visibilización permanente: la crinolina y el control de las interacciones....................111

3.5. La peluca: de la decoración a la inmovilización......................................................................................114

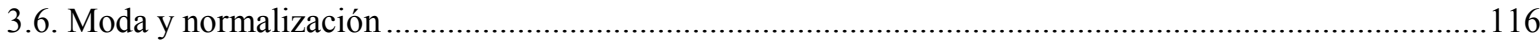

3.7. Vestir y castigar: normalización, belleza y heterosexualidad obligatoria ..............................................120

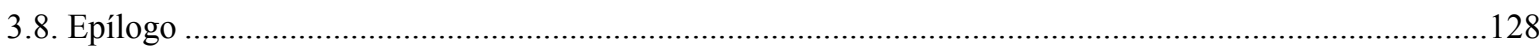

CAPÍTULO 4. De las modas disciplinarias a las biopolíticas vestimentarias................................................129

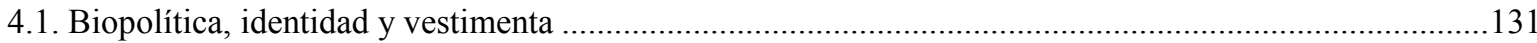

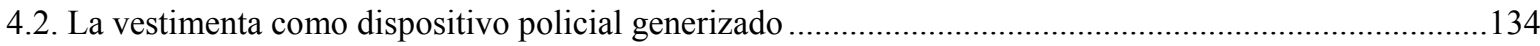

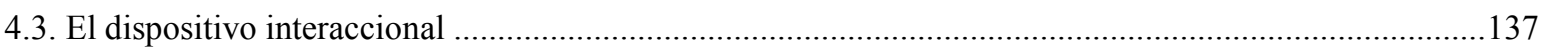

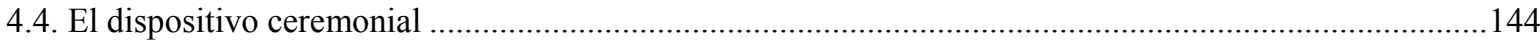

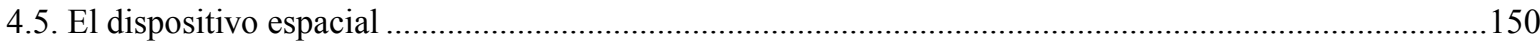

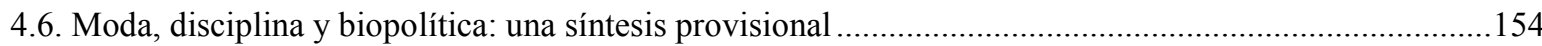

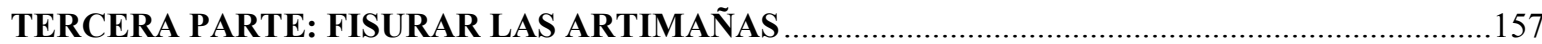

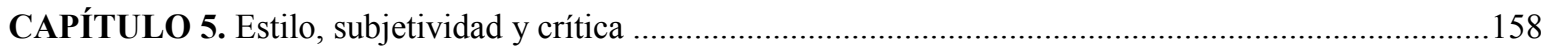

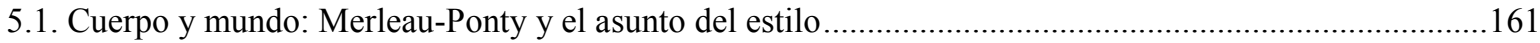

5.2. Los estilos juveniles: la Escuela de Birmingham y la vestimenta .........................................................165

5.3. Subjetividad y crítica: la ética foucaultiana y la estilística de la existencia.............................................171

5.4. La performatividad butleriana y el estilo: sobre la posibilidad de ensanchar los parámetros de

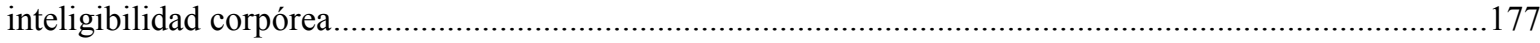

5.5. Cuerpo, vestimenta, performatividad y crítica: hacia una teoría del estilo ..............................................183

5.6. Los estilos de género ……......................................................................................................... 191

CAPítULO 6. Dandismo y feminismo: dos ejercicios críticos de estilo .........................................................196

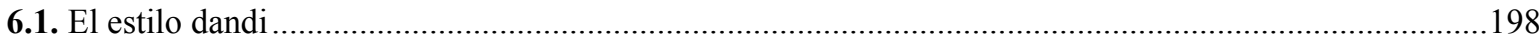

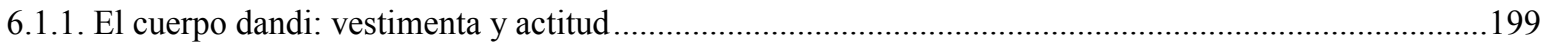

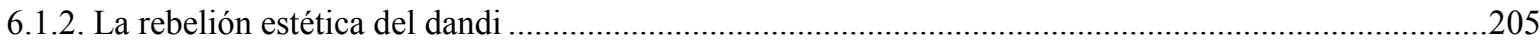

6.1.3. Los dispositivos dandis: las prendas como insumos estilísticos ..........................................................210 
6.2. El estilo feminista

6.2.1. El feminismo en cuanto estilo .223

6.2.2. El cuerpo vestido como herramienta crítica: algunas características del estilo feminista......

6.2.3. De los esfuerzos reformistas a las mujeres deportistas: en busca de un estilo con movimiento

6.2.4. Las luchas feministas por el reconocimiento y el estilo como elemento de protesta: el ejemplo sufragista

6.2.5. El rechazo de las técnicas de embellecimiento como ejercicio de estilo

CAPÍTULO 7. Brotes estilísticos andróginos: a propósito de la posibilidad de un estilo allende el género.

7.1. La androginia mítica

7.2. De la disposición perversa polimórfica a la sustancia viva escindida: los avatares de la androginia platónica en el psicoanálisis freudiano .253

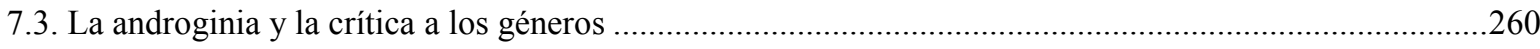

7.4. La dimensión política de la androginia: la ontología andrógina como enclave de la crítica ...................266

7.5. En busca de un linaje: elementos para el rastreo histórico del estilo andrógino ..................................271

7.6. Los distintos estadios de un estilo profano: algunos brotes de estilo andrógino..................................274

7.7. A manera de epílogo: las nuevas posibilidades del estilo andrógino ................................................280 


\section{Agradecimientos}

Escribí esta tesis mientras disfrutaba de una generosa beca otorgada por la Universidad de Costa Rica para tales efectos. Deseo comenzar este trabajo agradeciendo sinceramente a dicha casa de estudios y especialmente a su Escuela de Filosofía el haber hecho posible que un joven docente e investigador de la Universidad como yo pudiese continuar su formación académica fuera del país.

Quisiera agradecer, por otro lado, a la Doctora María Luisa Femenías su labor como directora de esta investigación. La profesora Femenías no solo leyó y corrigió mi trabajo con una profundidad y un rigor al que nunca antes me había visto enfrentado, sino que además fue una persona atenta y solidaria conmigo desde antes de conocerme personalmente cuando le enviara mi proyecto desde Costa Rica. Espero que algo de su erudición y de su calidad académica hayan dejado su impronta en mi investigación. Agradezco a la Dra. Femenías, además, el haberme involucrado en los proyectos de investigación "La filosofía de Judith Butler: una relectura crítica de la constitución del sujeto" -inscrito en calidad de UBACyT en la Universidad de Buenos Aires- y "La constitución del sujeto agente: los aportes de la filosofía de Judith Butler y su influencia actual" - proyecto de investigación radicado en el Centro Interdisciplinario de Investigaciones en Género de la Universidad Nacional de La Plata-, en los cuales pude discutir algunos textos que a la postre resultarían centrales en la confección de este escrito. Deseo extender asimismo un agradecimiento a las compañeras que integraron esos proyectos de investigación por su voluntad de incluirme en las discusiones y por su actitud respetuosa hacia mi trabajo.

Por otra parte, agradezco a la codirectora del presente trabajo, la Dra. Laura Gioscia, quien tuvo igualmente la mejor disposición hacia mi investigación, así como la hospitalidad de recibirme mientras hacía una breve pasantía en Uruguay como parte de mi labor. 
Quiero agradecer muy especialmente a Catalina Cartagena su apoyo durante el tiempo que estuve realizando mis estudios doctorales. Ella no solo ha sido una aguda interlocutora desde la primera hasta la última faceta de mi investigación, sino que también ha sido una fuente constante de aliento y compañía. Creo que este trabajo es en cierto sentido el resultado de un clima afectivo que supimos crear juntos.

Agradezco también a algunos colegas y/o amigos que hicieron que la distancia de mi lugar de origen tomase dimensiones soportables mientras preparaba mi trabajo: Roberto Fragomeno, Manuel Triana, Liceth Alvarado, Abril Retana, Jacqueline García, Martín Legeren, Omar Ameghino, Laura Chinchilla, Emiliano Villalta, Maya San Martín, Alma San Martín, Jenny Melo, Byron Ospina, Juan Carlos Escobar, Jeymer Gamboa, Elena Arguedas y Paulo Calvo. Todos ellos supieron ayudarme a ponderar distancias, ausencias y nostalgias de manera que mi experiencia en Argentina resultara rica y transformadora.

Por último, quiero agradecer a Jorge Jiménez y Alexander Jiménez, al lado de quienes, sin duda, todo esto empezó. 


\section{Introducción}

Tema supuestamente prosaico y ajeno a las sofisticaciones de la filosofía, la moda goza sin embargo de una suerte de omnipresencia cultural. Así al menos lo afirma el filósofo y sociólogo berlinés George Simmel en un importante texto que habrá oportunidad de examinar detalladamente más adelante -me refiero, naturalmente, a su Filosofía de la moda-: "si ir a la moda es imitación de [un] ejemplo, ir deliberadamente 'dèmodè' es imitar lo mismo, pero con signo inverso" (Simmel, [1905] 2008, 83). El certero diagnóstico simmeliano pareciera, por lo demás, seguir actualmente vigente. El historiador y semiólogo español Jorge Lozano, por ejemplo, considera que "no se puede vivir al margen de la moda; las dos conductas extremas, la del fashion victim y la de su simétrico opuesto, el démodé, se encuentran igualmente dentro de su perímetro" (Lozano, 2007, 23). ¿Cómo explicar entonces la apatía de la filosofía hacia una institución que, como la moda, no conoce de indiferencias?

En realidad, sería exagerado aseverar que el asunto de la vestimenta constituye un anatema para la filosofía. Foucault, por ejemplo, ha demostrado que dentro de la problematización antigua de la libertad el vestir constituía un elemento de importancia para los filósofos (Foucault, [1984] 2010b, 1032; volveré in extenso sobre esta postura foucaultiana en el capítulo 5). Rousseau, por su parte, dedica algunas páginas en el Emilio a determinar cuál debería ser la forma adecuada de vestir a los niños -véase, entre varios fragmentos posibles, Rousseau ([1762] 2011, 60-61)-.

Otros filósofos inclusive se ocupan del tema otorgándole una cierta centralidad. Kant, por ejemplo, llega a hacer del vestido y del pudor [sittsamkeit] que este manifiesta el fundamento mismo de la sociabilidad ([1786] 2010, 114-115). Toda vez que en el episodio bíblico Adán y Eva se cubren con la hoja de parra como resultado de su conciencia de encontrarse desnudos, Kant asegura, en su interpretación del Génesis, que la aparición de la indumentaria y la capacidad de sustraer al deseo sexual de su 
inmediatez mediante el cubrimiento del cuerpo, involucra un tránsito "del mero deseo animal al amor y, con éste, del sentimiento de lo meramente agradable al gusto por la belleza" ( [1786] 2010, 114). En esta medida, para el filósofo de Königsber, "la hoja de parra (Génesis, III, 7) fue (...) el producto de una manifestación de la razón” (Kant, [1786] 2010, 114). Kant señala en este mismo sentido que la capacidad técnica de confeccionar e implementar vestidos otorga una especificidad al ser humano en relación con los animales, de los cuales, dicho sea de paso, el ser humano obtiene la materia prima para la confección de sus atavíos:

[...] la primera vez que le dijo a la oveja: la piel que te cubre no te ha sido dada por la Naturaleza para ti, sino para mí, arrebatándosela y revistiéndose con ella (Génesis, V, 21), el hombre [sic] tomó conciencia de un privilegio que concedía a su naturaleza dominio sobre los animales, a los que ya no se consideró como compañeros en la creación, sino como medios e instrumentos para la consecución de sus propósitos arbitrarios (Kant, [1786] 2010, 114).

Hegel, por su parte, denuncia en el segundo volumen de la Estética ([1842] 1983) las inconveniencias de los vestidos de su época en comparación con la vestimenta antigua. En su opinión, "el corte actual de nuestros trajes es inartístico y prosaico frente a la vestidura más ideal de los antiguos" (Hegel, [1842] 1983, 118-119). Así, para el filósofo, los pliegues y el corte en general deberían alentar la libertad de movimiento en lugar de restringirla. La ropa debe adecuarse al cuerpo y no a la inversa: "la estructura de los miembros regula, sin duda, la forma del vestido; pero en esta forma corpórea la vestimenta es, por cierto, solo un mal remedo o una deformación de los miembros humanos, según la moda convencional" ([1842] 1983, 119). En opinión de Hegel, la vestimenta debe, por lo tanto, poseer la suficiente flexibilidad para que el cuerpo encarne lo ideal, en razón de lo cual, una prenda adecuada es aquella que no roba protagonismo a quien la porta. Hegel propugna, así, un

uso de las cosas naturales para una satisfacción puramente teorética. A estos pertenece cada atavío y adorno que el hombre se aplica (...). Mediante [el] ornamento [el ser humano] muestra lo más costoso que ofrece la naturaleza y lo más bello, (...) pero esto, lo más raro y lo más brillante, no es ya de por sí atrayente ni debe valer como lo natural, sino que tiene que mostrarse en él (Hegel, [1842] 1983, 237-238). 
De este breve vistazo se infiere ya algún grado de interés filosófico en el asunto de la indumentaria. La vestimenta pareciera, en efecto, comportar relevancia para el pensamiento o al menos figurar dentro de conjuntos de preocupaciones filosóficas más amplios. Pero pese al interés de los filósofos aludidos por la vestimenta, las tesis anteriormente referidas son a todas luces, si bien no menores, sí al menos observaciones circunstanciales, realizadas en contextos en los que el foco de atención no son los vestidos per se. En una palabra, cuando aparece, la filosofía aborda el tema de la indumentaria sin mayor ánimo de sistematicidad. Kant, por ejemplo, se refiere al texto en el cual realiza sus reflexiones sobre el vestido como "un simple viaje de placer" ([1842] 1983, 110), al tiempo que el resto de pensadores mencionados hacen referencia al tema de la indumentaria de una forma pasajera.

De hecho, no se encuentra ninguna obra canónica en la historia de la filosofía dedicada al tema de la moda, y habrá que aguardar hasta principios del siglo XX, con las teorías del pensador estadounidense Thorstein Veblen y del ya mencionado George Simmel, para encontrar textos filosóficos expresamente dedicados al tópico en cuestión. Se trata, por lo tanto, de una situación paradójica: pese a la omnipresencia de la moda y al hecho señalado por Simmel y Lozano de que no es posible escapar a sus dominios, los filósofos, al menos hasta el siglo XX, apenas y se ocupan de la cuestión y solo de un modo periférico.

En cambio, a lo largo del siglo pasado, en buena medida con los trabajos pioneros de Veblen y Simmel, ese panorama muta. A partir de una serie de estudios que comienzan a abordar desde distintas perspectivas el problema del vestido y de su relación con lo social, la moda se revela, en efecto, como un asunto filosóficamente problemático. Una serie de cuestiones empiezan, en consecuencia, a ser discutidas en torno de la relación entre lo vestimentario y lo cultural. Así, aparecen durante esta época reflexiones sobre el vestido ligadas a cuestiones estéticas (por ejemplo al porqué de la preferencia de unas prendas por sobre otras), éticas (vinculadas a la relación entre las prendas y los comportamientos), políticas (asociadas especialmente a la relación entre el vestido y el 
consumo), epistemológicas (conectadas con la dimensión sígnica del vestido y la elaboración de mensajes a través del diseño de prendas) y metafísicas (v. gr. en lo tocante al ligamen entre la naturaleza del ser humano y al estatuto cultural de los vestidos). A partir de las elaboraciones de Veblen y Simmel, así como de los autores que les siguieron, la moda se instituye, de esa manera, como un campo en sí mismo problemático.

No obstante, pese a lo interesante de estas teorías, el objetivo de la presente investigación no consiste en realizar una sistematización o un resumen de las mismas. De hecho, no pretendo aquí llevar a cabo un compendio de las opiniones de los filósofos respecto del tema de la vestimenta. Si bien en la primera parte de este trabajo me dedicaré a analizar los contenidos de las teorías sobre la moda más citadas y especialmente a poner a sus autores en relación unos con otros así como con un conjunto de conceptos, esta tesis no constituye un trabajo de naturaleza únicamente exegética. Por el contrario, a partir de la premisa de que alrededor de las explicaciones surgidas a lo largo del siglo XX acerca de la moda existen una serie de núcleos teóricos insuficientemente problematizados y susceptibles de una crítica que devele sus mecanismos internos así como sus consecuencias discursivas, uno de mis objetivos en este trabajo es desarrollar una reflexión que se ubique por entre los surcos y los "puntos ciegos" de dichas teorías. En otras palabras, siendo que en el siglo XX se conforma una suerte de canon alrededor del problema de la vestimenta, en un principio ese canon conforma el punto de partida de la presente investigación; pero a partir de la crítica de esa tradición teórica mi objetivo es analizar la moda desde otra perspectiva. Aspiro, pues, antes a pensar en la estela dejada por una tradición que a componer una doxografía de la misma.

Así, partiendo de una lectura problematizadora de los estudios sobre moda inaugurados por Veblen y Simmel, me interesa realizar una interrogación acerca de algunas aristas del problema de la moda hasta cierto punto inadvertidas. Especialmente, mi interés radica en analizar la compleja relación entre la vestimenta y el cuerpo -relación que, no obstante su manifiesta importancia, no ha ocupado el centro de las discusiones más que en algunos tramos de la obra del sociólogo francés Pierre Bourdieu (véase al respecto el apartado 
1.2)-. De hecho, si bien la moda involucra necesariamente los cuerpos, el ligamen entre una y otros pareciera abiertamente soslayado en las teorías mencionadas. O mejor: el cuerpo de los teóricos de la moda pareciera asumir sus caracteres de otros imaginarios y registros, en razón de lo cual su funcionamiento en el marco de las teorías de la moda resulta problemático y políticamente discutible.

Así, me interesan los discursos sobre la moda en la medida en que han contribuido a fijar unos parámetros culturales desde los cuáles se piensa la relación del cuerpo con el vestido. En este sentido, mi postura es que la moda, en tanto fenómeno cultural, no es enteramente discernible de aquello que las teorías dicen sobre ella; interrogar las teorías sobre la moda implica, en este sentido, cuestionar los parámetros desde los cuales comprendemos nuestra relación con los vestidos.

Desde esta perspectiva, quisiera proponer una interpretación de la moda en la que la relación entre el vestido y el cuerpo no aparezca como dada a priori, y en la que esos conceptos, por el contrario, se erijan como núcleos interrogativos. Mi hipótesis de trabajo, por ende, es que en la moda se encuentran en juego una serie de procedimientos de control o artimañas que merecen no solo detectarse en su formulación teórica y descifrarse en su funcionamiento social, sino también develarse en su contingencia. Se trataría, en suma, de construir un marco desde el cual examinar la relación hasta cierto punto obliterada de la moda con los cuerpos, para así detectar, en los dobleces de diversos discursos y prácticas, el modo en que la vestimenta consolida, instituye, refuerza y legitima -o en su defecto cuestiona, critica y discute- la administración de los mismos.

\section{Perspectiva teórica a seguir}

En términos generales el objetivo central de esta investigación es, según se desprende de lo anterior, llevar a cabo una genealogía de la moda. Por genealogía entiendo, partiendo de la interpretación foucaultiana de Nietzsche (Foucault, [1971] 1992), el procedimiento

crítico que muestra el carácter histórica y ontológicamente contingente de una práctica de 
poder determinada. En el caso de la moda, un análisis genealógico tendría que discutir los fundamentos teóricos e históricos con base en los cuales se naturalizan ciertas prácticas de poder ejercidas sobre el cuerpo a través de la vestimenta. En otras palabras, realizar una genealogía de la moda involucra indagar el modo en que a partir de la implementación social de políticas sobre el aspecto y el vestido se controlan, moldean y producen subjetividades. Desde esta perspectiva, la moda no constituiría un fenómeno relacionado únicamente con el modo en que se ven los cuerpos, sino que también involucraría procedimientos de atavío mediante los cuales se contribuye a producir esos mismos cuerpos (véase al respecto la segunda parte del presente trabajo).

La moda, en tanto problema, remite así en un contexto genealógico de un modo general al ámbito del vestido y no al campo del consumo. El vestido, por ende, no designa aquí de forma restrictiva aquello que cubre el cuerpo a la manera de una cosa enteramente separada y distinta del mismo (profundizaré este argumento en el capítulo 2). Por el contrario, como lo señalan las teóricas de la moda estadounidenses Johnson, Hegland y Schofield,

[...] el vestido de un individuo consiste en todas las modificaciones hechas al cuerpo humano y/o a los suplementos del cuerpo. A partir de esta definición, el vestido incluye una larga lista de modificaciones hechas al cuerpo tales como la perforación de las orejas y los tatuajes, así como suplementos para el cuerpo tales como la ropa y la joyería $(1999,11$; traducción propia).

La moda, en este sentido, se relaciona desde mi punto de vista con conjuntos de transformaciones corporales y con los discursos que los dotan de sentido. Asimismo, la moda involucra procedimientos mediante los cuales se implementan unas prácticas vestimentarias que privilegian unos ciertos ideales corporales por sobre otros. En suma: la moda remite en el contexto de esta investigación a procedimientos de gestión corporal que trabajan los cuerpos con base en una idea previa y esencializada de lo que estos son.

Ahora bien, si examinar la moda desde un punto de vista genealógico implica desprenderse de la idea de unos cuerpos y unas subjetividades esenciales, ello supone 
asimismo detectar los enclaves a partir de los cuales se construyen esas ficciones esencializantes. En otras palabras, someter la moda a una crítica genealógica involucra revisar sus puntos de partida, falsar sus criterios de verdad y ocuparse, como diría Foucault, de los azares de sus comienzos ([1971] 1992, 12). En el caso de la vestimenta una crítica de esta naturaleza no podría dejar de contemplar el problema del género. En efecto, tal y como lo mostraré más adelante, la moda no pareciera disociable del conjunto de dispositivos de poder dedicados a la producción de los géneros sexuales. Foucault se refiere al concepto de dispositivo como

[...] un conjunto decididamente heterogéneo, que comprende discursos, instituciones, instalaciones arquitectónicas, decisiones reglamentarias, leyes, medidas administrativas, enunciados científicos, proposiciones filosóficas, morales, filantrópicas; en resumen: los elementos del dispositivo pertenecen tanto a lo dicho como a lo no dicho. El dispositivo es la red que puede establecerse entre estos elementos[:] la naturaleza del vínculo que puede establecerse entre ellos ([1977] 19991, 128-129).

En el caso de la moda esos conjuntos complejos y variopintos de discursos y prácticas que conforman los dispositivos aparecen, según mi opinión, estrechamente vinculados con la producción y el mantenimiento de cuerpos sexuados. Los sexos, con respecto a la moda, funcionan así como fundamento de unas prácticas, al tiempo que como resultado necesario de la implementación de las mismas (véase al respecto el capítulo 2). Así, si la genealogía, tal y como la conceptualiza Foucault, tiene por objeto mostrar el carácter contingente de aquello que se presenta como necesario, en el caso de la moda, realizar un análisis genealógico requiere necesariamente reparar en el hecho de que los dispositivos de poder relacionados con el vestido se apoyan de una manera casi invariable en una metafísica binaria de los sexos. En otras palabras, interrogar genealógicamente la moda implica analizar el modo en que el binarismo sexual funciona como "verdad" de los cuerpos al tiempo que como enclave a partir del cual la moda estructura y despliega sus artimañas.

De esta manera, si las artimañas de la moda - a saber, el conjunto de mecanismos de poder desplegados a través de la vestimenta- se soportan sobre la base de un binarismo 
sexual tenido por verdad metafísica, una genealogía como la que pretendo llevar a cabo debe, necesariamente, hacerse desde una perspectiva de género. Así, toda vez que las prácticas de poder involucradas en el vestido parten del género como grilla de inteligibilidad y como núcleo antropológico esencial y que el feminismo constituye un esfuerzo teórico dedicado a repensar y criticar el modo en que de los géneros se siguen prácticas de dominación y de violencia, una genealogía de la moda requiere necesariamente del empleo de una perspectiva feminista.

En términos generales, pues, este trabajo podría ser leído como una genealogía de la moda con enfoque de género. Según la filósofa estadounidense Judith Butler una genealogía con enfoque de género se destaca precisamente por analizar el modo en que una serie de procedimientos políticos desembocan en la producción cultural de los sexos ([1993] 2008, 53). En opinión de Butler -aunque la autora parte expresa y polémicamente de las elaboraciones de Simone de Beauvoir-, los sexos (así como los géneros) resultan de una serie de discursos y prácticas que pretenden consolidar una "esencia" masculina y una femenina así como una relación asimétrica entre ambas (me extenderé a propósito de la posición butleriana en varias instancias posteriores del presente trabajo; véanse, por ejemplo, los apartados 2.6. y 5.4). Los sexos, dentro de una genealogía feminista no constituyen, así, verdades transhistóricas, sino que por el contrario son resultado de una serie de políticas corporales a partir de las cuales se instituyen y fundamentan las relaciones de poder entre varones y mujeres. En el caso de la moda, implementar esta perspectiva implica, por lo tanto, pensar de qué modo el vestido se soporta sobre la base de los géneros para llevar a cabo una serie de procedimientos a través de los cuales el cuerpo se ve en/vestido por diversos dispositivos generizantes que pretenden domeñarlo.

En síntesis, mi objetivo en lo que sigue será mostrar que la moda no es una institución que se limite a regular el acicalamiento de unos cuerpos previamente constituidos. En consecuencia, sostendré que en la moda hay en juego políticas dirigidas a la producción de los cuerpos, así como dispositivos proyectados para la formación y consolidación de los géneros. No obstante, si bien es cierto que alrededor de la moda se urden estrategias de control y se traman artimañas, mi intención con este trabajo es también demostrar que 
dichas artimañas carecen de una eficacia completa, en razón de lo cual es posible su crítica y su eventual resquebrajamiento.

\section{El recorrido del texto}

En aras de desplegar el análisis recién descrito, el presente trabajo está dividido en tres partes. En la primera parte, intitulada "La moda y el cuerpo" y compuesta a su vez por dos capítulos, me dedico a realizar una reconstrucción del modo en que la vestimenta se convierte en un problema teórico, así como de la manera en que dicha problematización desemboca en una episteme en la cual el cuerpo ocupa un lugar tan ammiguo como problemático.

El primer capítulo, titulado "La conformación de una episteme: las teorías sobre la moda y la centralidad del asunto de la difusión", se compone de cinco apartados en los cuales pretendo cartografiar la moda en tanto problema teórico. En el primero de estos apartados realizo una caracterización de las primeras teorías sistemáticas en torno a la moda elaboradas por Thorstein Velblen y George Simmel. En tanto estos autores poseen un alto grado de influencia en elaboraciones posteriores, en el segundo apartado sostengo que sus teorizaciones respecto del binomio moda-difusión, sus posiciones alrededor del tema de la imitación y su planteamiento acerca de la conexión entre vestimenta e identidad conforman una grilla de inteligibilidad de la que la filosofía de la moda depende todavía. En el tercer apartado realizo una descripción de la teoría psicológica sobre el vestido realizada por el psicólogo alemán J.C. Flügel, así como de su propuesta de una liberación vestimentaria a través del nudismo. Tomando esta obra paradigmática de la psicología del vestido, inscribo la empresa de la psicología de la moda dentro del marco problemático fundado por los teóricos de la emulación discutidos en el apartado anterior. En el siguiente apartado discuto la filosofía de la moda estructuralista del semiólogo francés Roland Barthes. Barthes es presentado allí como heredero del problema clásico del origen de los significados transmitidos por el vestido. Su filosofía de la moda, sin embargo,

optaría por intentar solucionar dicho problema situándolo en un ámbito más accesible 
para el análisis semiológico, a saber, las revistas de moda. En el quinto apartado desarrollo la tesis de que, pese a los esfuerzos de su autor por evitarlo, la teoría de la moda del sociólogo y filósofo francés Gilles Lipovetsky constituye una continuación más de las teorías clásicas de la emulación. Desde est perspectiva, interpreto la asociación lipovetskyana moda-modernidad como una operación que se limita a caracterizar las coordenadas histórico-políticas dentro de las cuales se despliega un fenómeno de la moda que, sin embargo, sigue siendo abordado desde la matriz teórica de la emulación propuesta por Veblen y Simmel.

En el segundo capítulo, intitulado "El cuerpo desnudo", planteo que una vez deconstruida la histórica articulación epistemológica entre moda y difusión (y por lo tanto la trama conceptual conformada por las nociones de identidad, lenguaje, emulación y consumo), cabe abrir una veta investigativa que se pregunte por las relaciones entre moda y poder. Esto es: a partir de la lectura de los distintos autores estudiados a lo largo del primer capítulo, en el segundo planteo la posibilidad de analizar la moda desde una perspectiva en la que el cuerpo no aparezca como algo dado, sino como una fuente de problematización. En esa línea, el capítulo también intenta problematizar el gesto teórico que hace de la desnudez una noción axial a la hora de enmarcar la moda como problemática filosófica. Así, argumento que repensar el cuerpo desnudo tal y como aparece en esas teorías equivale a abrir una puerta para plantearle a la moda una serie de preguntas filosóficas que históricamente se han dejado de lado. En el primero de los seis apartados analizo la estratégica utilización de la noción de desnudez dentro de las tramas retóricas de las distintas filosofías de la moda analizadas en el primer capítulo. La hipótesis del apartado es que los discursos teóricos analizados en el capítulo anterior dependen del cuerpo desnudo entendido como reducto natural anterior a lo social. En el segundo apartado sostengo, por otra parte, que dicha comprensión de la corporalidad valida una ontología de la moda que inscribe la problemática de la vestimenta en un registro biológico en el que las metáforas belicistas estructuran buena parte de lo que se dice sobre los vestidos y el cuerpo. Partiendo con Femenías de una comprensión de la metáfora como un recurso valorativo "que consiste en dar a una cosa el nombre que pertenece a otra" (Femenías, 1999, 4), así como de los análisis de los teóricos 
estadounidenses Lakoff y Johnson y de las filosofías de Michel Foucault y de la feminista estadounidense Donna Haraway, intento mostrar que la guerra es una grilla de inteligibilidad moderna que permea distintos discursos sociales. Así, en el caso del vestido, planteo que esas capas metafóricas darían sentido a nivel discursivo a una serie de prácticas de poder que giran en torno a la moda. En el tercer apartado analizo algunas de las metáforas bélico/biologicistas presentes en los discursos teóricos sobre la moda. En el cuarto apartado, ahondo en la tesis de que la desnudez es un reducto epistemológico no problematizado por los teóricos del vestido. A partir de la premisa del filósofo italiano Giorgio Agamben de que toda desnudez es enunciada mediante un dispositivo, planteo la posibilidad de analizar de qué manera esas prendas que se supone que se limitan a cubrir un cuerpo dado en realidad se avocan a producirlo. En el quinto apartado discuto, a partir de la crítica previa a la utilización retórica de la noción de desnudez, la posibilidad de pensar la moda como un dispositivo de poder y de gestión corporal. En el sexto apartado, por último, presento el cuerpo no ya como una materialidad dada sino como una superficie de intervención social en la que los vestidos ocupan un lugar políticamente relevante.

La segunda parte, titulada "Descifrar las artimañas" y compuesta por los capítulo tercero y cuarto, consiste en un análisis del modo en que se articulan una serie de procedimientos políticos, estéticos y ontológicos en aras de producir dispositivos de poder vestimentarios.

En contraposición a los enfoques sobre el problema del vestido estudiados en la primera parte, en el tercer capítulo, denominado "Moda y disciplinamiento", me propongo realizar un análisis de la moda que prescinda de una concepción de sujeto previa a las en/vestidas del poder. En aras de desmantelar la antropología subyacente a las teorías de la moda, en este capítulo sostengo que en torno a la vestimenta tienen lugar una serie de prácticas de poder cuyo norte es el disciplinamiento del cuerpo generizado y la instauración de regímenes de deseo. Esto es: si las modas y los discursos que teorizan en torno a ellas suponen una noción de cuerpo, ello contribuye a obliterar la dimensión disciplinaria de la vestimenta. En tal sentido, la moda es estudiada en el capítulo en 
cuestión como un dispositivo de poder que no solo contribuye a construir los cuerpos, sino que también regula las políticas del deseo a partir de las cuales se relacionan dichos cuerpos. En consecuencia, en el primer apartado sostengo que la moda se inscribe en un régimen de verdad (foucaultiano sensu) cuyo núcleo antropológico se ancla en la diferencia sexual. Así, los cuerpos presociales (biologizados) que supuestamente viste la moda son presentados más bien como el resultado de dispositivos de generización que establecen performativamente "verdades" (no obstante contingentes) sobre los sujetos corporales. A partir de las teorizaciones de Judith Butler, planteo que la moda forma parte, por tanto, de un conjunto de dispositivos de control sobre el cuerpo dirigidos a disciplinar el género; a saber: la moda constituiría, desde mi perspectiva, lo que en la terminología de Teresa de Lauretis se denomina una "tecnología de género". En aras de mostrar el punto anterior, los apartados siguientes proporcionan algunos ejemplos históricos de prendas que podrían ser consideradas auténticos dispositivos correctores (v. gr. el corsé -tercer apartado-, la crinolina -cuarto apartado- y la peluca -quinto apartado-). Interpretando a Foucault, en el sexto apartado argumento en esta misma línea que la moda, en tanto dispositivo de poder disciplinario, posee una forma específica de reprobar las desviaciones: la sanción normalizadora. A partir de dicha vocación normalizadora, en el séptimo apartado sostengo que la moda es un dispositivo que no solo se encarga de generizar los cuerpos mediante el disciplinamiento sino además de, una vez generizados, castigar con una saña particular los cuerpos clasificados como femeninos. Por último, en el octavo apartado realizo un balance de lo sostenido en los apartados anteriores y postulo la necesidad de realizar un análisis biopolítico de la moda que se complemente con el análisis disciplinario llevado a cabo a lo largo del capítulo.

El cuarto capítulo, "De las modas disciplinarias a las biopolíticas vestimentarias", se dedica precisamente a complementar el análisis del capítulo anterior sumando a la dimensión disciplinaria de la moda un análisis de la vestimenta en tanto estrategia de control biopolítico. En razón de ello, en el primer apartado abordo la moda como un dispositivo biopolítico que contribuye a marcar los cuerpos de la población. En esta línea, argumento que la vestimenta es un dispositivo de gobierno que permite la clasificación, distribución y jerarquización de los cuerpos. Mediante una lectura 
combinada de tesis foucaultianas y de algunos argumentos de la feminista británica Virginia Woolf, mi hipótesis en este apartado es que al lado de su carácter disciplinario, la moda dota de inteligibilidad los cuerpos a partir de su género para así organizar la vida de los mismos dentro del territorio. La labor de organización de la vida colectiva descrita en el primer apartado posee así, según el segundo, un carácter policial en el sentido foucaultiano del término. Por ende, a pesar de que la moda apela la mayoría de las veces a los deseos de lo individuos en lugar de utilizar la coerción directa, mi planteamiento es que la funcionalidad biopolítica de las prendas depende de su naturaleza policial: esto es, de su capacidad para gestionar interacciones, desplazamientos y actuaciones a partir del establecimiento de parámetros de reconocibilidad. En los siguientes apartados discuto esa vocación policial de la biopolítica vestimentaria en tres de sus manifestaciones más palmarias. Así, el tercer apartado está dedicado al examen de la gestión de las interacciones mediante el vestido, el cuarto al estudio del control indumentario de la actuación de los cuerpos por fuera de los ámbitos recortados por las disciplinas y el quinto a la descripción de la producción de biopolíticas vestimentarias regulatorias del espacio. Por último, el sexto apartado ensaya una síntesis provisional entre, por un lado, la dimensión disciplinaria involucrada en la moda y descrita en el capítulo tercero y, por otro, la dimensión biopolítica de la indumentaria analizada a lo largo del cuarto capítulo.

En la tercera y última parte, titulada "Fisurar las artimañas", pretendo, una vez puesto en evidencia el carácter filosófica e históricamente contingente de las relaciones de poder derivadas de la moda, pensar un panorama en el que la vestimenta y el cuerpo entablen otro tipo de vínculo allende las coerciones disciplinarias de género estudiadas en la segunda parte. Así, en los tres capítulos que componen esta parte del trabajo, la moda cede el foco de atención al estilo, aunque permanece a la manera de un trasfondo normativo a partir del cual las prácticas estilísticas se hacen posibles.

De esta forma, en el quinto capítulo, titulado "Estilo, subjetividad y crítica", me dedico a revisar los distintos modos en que se ha conceptualizado filosóficamente hablando la noción de estilo. En el primer apartado analizo la propuesta del fenomenólogo francés Merleau-Ponty y su referencia al estilo como un concepto propiamente corporal. En el 
segundo apartado paso revista a la conceptualización del estilo como una práctica propiamente vestimentaria en el seno de las reflexiones de la Escuela de Birmingham. El tercer apartado se refiere a la conceptualización foucaultiana de los estilos de existencia y al concomitante vínculo establecido por el filósofo francés entre estilo, crítica y subjetividad. En el cuarto apartado analizo la lectura butleriana del estilo como una práctica corporal igualmente vinculada al cuerpo, la indumentaria y la crítica, pero además relacionada con la performatividad. Por último, ensayo una articulación de los conceptos de cuerpo, vestimenta, performatividad y crítica (quinto apartado), para concluir sosteniendo un vínculo estratégico entre dichas nociones y la impugnación de las normas de género (sexto apartado).

En el sexto capítulo, intitulado "Dandismo y feminismo: dos ejercicios críticos de estilo", intento leer algunos episodios históricos a partir de la teoría del estilo construida en el capítulo anterior. Se trata de utilizar una lente filosófica para interpretar algunos fragmentos de la historia de la moral y la política (aunque también de la historia del vestido) para intentar comprender el modo en que han tenido lugar ejercicios éticos de estilo dentro de disputas sociales por el reconocimiento. En la primera sección, dedicada al estilo dandi y compuesta por cuatro apartados, planteo el dandismo, allende su dimensión literaria, como un estilo vestimentario con un ethos particular. En el primer apartado de dicha sección discuto el modo en que podría entenderse la actitud crítica dandi como una forma de crítica estilística. En el segundo apartado intento mostrar la veta metafísica de la actitud dandi, entendida como forma de insuflar formas críticas al cuerpo. En el tercer apartado analizo la dimensión espiritual propia de la utilización dandista de las prendas, esto es, la inscripción por parte del dandi del atavío dentro de una concepción ética y estética de la existencia. Por último, en el cuarto apartado, me refiero a algunas de las limitaciones políticas del estilo dandi. En concreto, hago alusión a su excesivo culto a la singularidad (el cual, en mi opinión, pone trabas a la conformación de una crítica vestimentaria dandista a gran escala) y a su acriticidad en relación con los dispositivos vestimentarios dirigidos contra las mujeres. En la segunda sección del capítulo, ensayo una lectura del feminismo como ejercicio estilístico. En razón de ello, en el primer apartado me dedico a discutir la pertinencia de leer el feminismo, allende su 
dimensión teórica, como una práctica corporal que capitaliza el aspecto como recurso político. En el segundo apartado destaco algunos de los principales rasgos del estilo feminista. En el tercer apartado analizo uno de los flancos críticos más recurrentes dentro del estilo feminista: me refiero a la cuestión de la inmovilización del cuerpo femenino por vía de la indumentaria. En el cuarto apartado destaco la relación entre las luchas feministas por el reconocimiento y la cuestí́on del estilo. Especialmente, me centro en el ejemplo de los movimientos sufgragistas y su utilización del cuerpo vestido en el marco del espacio público. Por último, me refiero al rechazo feminista de los dispositivos de embellecimiento en términos de estilo; en concreto, estudio las réplicas feministas a los ideales de belleza como una práctica crítica de estilo.

El séptimo y último capítulo, intitulado "Brotes estilísticos andróginos: a propósito de la posibilidad de un estilo allende el género", consiste en un ejercicio de interpretación del fenómeno de la androginia en una clave estilística. Si el dandismo y el feminismo se presentan en el capítulo anterior como manifestaciones históricas de estilo crítico, la androginia, en cambio, es entendida como un núcleo estilístico que, si bien posee una cierta presencia histórica, hunde sus raíces sobre todo en la mitología y en el ámbito de lo imaginario. Por ello, en el capítulo realizo un esfuerzo por leer lo andrógino allende su dimensión mítica para considerarlo como un estilo crítico del binarismo sexual aún no desarrollado en toda su potencialidad. Así, el primer apartado expone la formulación del ideal andrógino en la filosofía platónica. El segundo analiza la recepción freudiana de dicho ideal, así como el ligamen establecido por el psicólogo de Viena entre el cuerpo andrógino y los géneros. El tercer apartado distingue el ideal andrógino de la condición genital hermafrodita. Así, en contra de Freud, sostengo la pertinencia de leer lo andrógino como un estilo vestimentario en lugar de leerlo como una forma anatómica. Asimismo, planteo que el cuerpo andrógino obtiene su especificidad de la crítica al binarismo tal y como este se produce a través del disciplinamiento vestimentario. En el cuarto apartado intento, a partir de la feminista candiense Shulamith Firestone, vincular esa crítica al binarismo sexual con una crítica ontológica y política de la cultura en general. En ese sentido, la androginia es discutida ya no únicamente como un ideal vestimentario crítico sino también como un ideal político. El quinto apartado ensaya una reconstrucción 
histórica del ideal andrógino. Para ello, me detengo a reseñar varias manifestaciones históricas del ideal vestimentario andrógino como lo unisex, lo camp y algunas otras estéticas coporales analizadas por el crítico y filósofo uruguayo Roberto Echavarren. Por último, el capítulo ensaya un análisis de las posibilidades futuras del estilo andrógino, especialmente en conexión con el tema de lo cibernético y de una crítica vestimentario/tecnológica a la idea -puesta en entredicho en el segundo capítulo- de un cuerpo natural.

En suma, este trabajo pretende vérselas con un tema que, como la moda, posee una alta influencia cultural y un rol fundamental en la vida de los cuerpos. Se trata, en ese sentido, de resistirse a ver en la moda únicamente una institución frívola, asociada con el encantamiento por el lujo y el consumo, para ver en ella un sitio en el que convergen una serie de procedimientos de control relacionadas con los cuerpos, los géneros, los placeres y los comportamientos. En otras palabras, si la moda aparece tanto en la cultura como en la teoría como una práctica más o menos anodina y superflua, lo que pretendo, en última instancia, es pasar esa mirada por el tamiz filosófico de la sospecha para mostrar el problema del vestido en toda su envergadura. Es decir, para mostrar que aún alrededor de ámbitos tan cotidianos como la vestimenta el poder trama sus artimañas, pero también la libertad despliega sus estrategias. 


\section{PRIMERA PARTE: \\ La moda y el cuerpo}

"nuestra identidad está bien protegida
por el envoltorio de nuestra ropa"

Heath y Potter, Rebelarse vende, 189

"el hombre [sic] puede actuar únicamente sobre características externas y visibles: a la naturaleza (...) nada le importan las apariencias"

Darwin, On the Origin of the Species, 53 


\section{Capítulo 1. La conformación de una episteme: las teorías sobre la moda y la centralidad del asunto de la difusión}

La reflexión a propósito de la moda es relativamente reciente, aún cuando la moda como problema no lo sea tanto. La explosión de estudios sobre el vestido, como lo he indicado ya, se desarrolla a lo largo del siglo XX, a pesar de que algunas obras literarias y filosóficas ya se referían al tema con anterioridad a ese momento - piénsese sobre todo en El pintor en la vida moderna de Baudelaire ([1862] 1995) y en los tratados de Balzac sobre el andar ([1830] 1998) y el vestir ([1833] 1998), textos sobre los cuales volveré en instancias posteriores de este trabajo-. Las teorías de la moda provienen de una serie de disciplinas muy diversas (economía, psicología, sociología, semiología, antropología, historia), pero todas ellas utilizan terminología filosófica y recogen problemáticas de ese ámbito del saber. De ahí que, grosso modo, quepa hablar de ellas como filosofías de la moda, aún cuando en ciertos casos se trate de formulaciones realizadas por sociólogos, historiadores, psicólogos o lingüistas, las más de las veces, en todo caso, con cierta perspectiva filosófica.

No obstante el carácter filosófico de dichas teorías clásicas sobre la moda, también es cierto que los análisis sobre el vestido nacen de la mano de la modernidad, razón por la cual se suele entender la moda en términos sociológicos como un fenómeno de consumo ligado al despliegue de la sociedad industrial y a la producción en serie. Sin embargo, este tipo de abordajes de la moda en términos de consumo acaban requiriendo de análisis de carácter estético, ético, ontológico y político que expliquen tanto el fenómeno de la difusión de las tendencias vestimentarias como sus consecuencias culturales. Ello genera que aún las teorías aparentemente más alejadas de la filosofía, acaben volviendo a proceder de un modo filosófico. La moda, entonces, a pesar de poseer un costado vinculado con el mundo de las mercancías y el consumo, posee una dimensión filosófica que viene dada por la naturaleza de los problemas teóricos que involucra. 
Así, en orden a responder a la pregunta de qué explica el consumo de vestidos, las diferentes teorías clásicas intentan crear teorías que den cuenta de los mecanismos difusores de la moda. En tanto se atribuye a la vestimenta, además, una dimensión simbólica, estas filosofías de la moda suelen ver en el vestido un canal de expresión de identidad $\mathrm{y}$, en esa medida, piensan en la indumentaria como una forma de lenguaje. A partir de este suelo común, un mismo conjunto de preguntas atraviesan las principales filosofías de la moda, por distantes que estas parezcan las unas de las otras. Se impone, pues, en el marco de un análisis como el que pretendo desarrollar acá, la necesidad de rastrear las problemáticas comunes a dichas teorías -aún cuando mi intención en este trabajo sea precisamente distanciarme de ellas a fin de poder realizar un análisis de la moda en tanto problemática eminentemente corporal-.

En este capítulo, por tanto, analizo ese cúmulo de preguntas compartido tanto por los teóricos de la emulación (Simmel y Veblen) y sus continuadores (el principal de los cuales es el sociólogo francés Pierre Bourdieu) como por la semiología estructuralista (Barthes), la psicología de la moda (Flügel), y los teóricos de la moda en tanto problemática moderna (Lipovetsky). Se trata de un recorrido que no quiere ser exhaustivo sino más bien mostrar las principales matrices a partir de las cuales se ha entendido la moda como un problema filosófico. Mi intención es mostrar cómo a pesar de sus disensos a la hora de responder a las interrogantes que se plantean, estas diferentes matrices teóricas coinciden a la hora de formular los problemas que consideran pertinentes, así como al articular dichos problemas en torno al asunto de la difusión. Con el fin de allanar el camino para realizar en capítulos posteriores un análisis de la moda en tanto forma de poder -y no ya únicamente en tanto fenómeno de consumo-, en el presente capítulo intentaré mostrar, por tanto, de qué manera los principales marcos teóricos que se han ocupado de la moda han priorizado algunos temas que -como el asunto de la difusión, de la relación entre vestido e identidad y de la indumentaria como forma de lenguaje- tienden a dejar de lado algunos núcleos filosóficamente problemáticos. 


\subsection{Moda, imitación y clase}

Cuando la reflexión filosófica vuelca su mirada hacia la moda, lo primero que encuentra es una lucha por la diferenciación y el prestigio. La vestimenta, en tanto elemento simbólico, se propone en las primeras reflexiones sistemáticas sobre la moda como una suerte de emblema distintivo que traza una línea divisoria entre imitadores e imitados. Como resultado de una sociedad cuyo eje comenzaba a ser la superproducción de objetos de consumo, entre ellos suntuosas prendas de vestir, los filósofos ven en la moda la manifestación de una batalla. Lucha por la diferencia, pero también combate entre clases que pujan por acceder a los ropajes que visibilizarían esas diferencias: esas son las coordenadas iniciales a partir de las cuales se interpreta la moda como un problema.

Hacia inicios del siglo XX el economista estadounidense y fundador del institucionalismo norteamericano Thorstein Veblen, así como el filósofo y sociólogo alemán Georg Simmel (ambos inspirados en el filósofo y científico Herbert Spencer) establecieron, cada uno por su propia cuenta, los fundamentos teóricos de lo que más tarde se daría en llamar el modelo del "filtrado descendente". La tesis central de este modelo, tal y como lo teorizaron originalmente los autores mencionados, consiste en señalar que en el centro de la problemática de la moda se encuentra el asunto de la emulación: "la moda es imitación de un modelo dado, y satisface así la necesidad de apoyarse en la sociedad" (Simmel, [1905] 2008, 73). La prenda aparece, asimismo, como un símbolo de distinción mediante la cual los individuos buscan alcanzar cierto estatus. Así, en medio de la batalla por el prestigio social, unos estarían a la vanguardia mientras que otros intentarían imitarles con tal de acceder al prestigio que ciertas vestimentas traen consigo. Los usuarios de la moda se pueden dividir, así, según este esquema, básicamente en dos clases: aquellos que se distinguen mediante el lujo y aquellos que buscan emular a los primeros.

La emulación resulta entonces de relaciones sociales asimétricas que generan un anhelo de prestigio, pero al mismo tiempo, constituye un dato de la naturaleza psicológica humana. Tanto Veblen como Simmel, en efecto, edifican alrededor de la moda una suerte 
de constructo metafísico mediante el cual el afán de distinción se explica por intermedio de rasgos antropológicos primitivos fundamentalmente instintivos. Las tensiones de clase generan una estructura piramidal, de forma tal que cuando una práctica vestimentaria ha permeado lo suficiente a los estratos más bajos de la pirámide, ello es un indicador de que dicha práctica ha pasado ya de moda. En última instancia, sin embargo, antes que de un fenómeno social, de lo que se trata es de la manifestación social de un problema esencialmente antropológico. Dentro de este enfoque, pues, el mecanismo difusor de las modas es la imitación de clases, por lo que el esquema de propagación de las tendencias, en opinión de Simmel, nunca varía: "siempre las modas son modas de clase, ya que las modas de la clase superior se diferencian de las de la inferior y son abandonadas en el momento en que ésta comienza a apropiarse de aquéllas" (Simmel, [1905] 2008, 79).

Según Veblen, el consumo de prendas de moda aparece, además, asociado al "ocio ostensible" ([1899] 2005, 75). En toda cultura, para este autor, habría un estadio primario de salvajismo pacífico en el que se privilegia el "instinto de trabajo eficaz" ([1899] 2005, 23). El esquema es el que sigue: si naturalmente el ser humano tiene propensión a fijarse fines y a intentar llevarlos a cabo de forma eficiente (esto es, sin derrochar energía de forma innecesaria) entonces en la naturaleza humana existirá un cierto desprecio por el esfuerzo inútil, y el mérito de un determinado individuo dependerá de su capacidad de realizar una tarea sin despilfarrar energías. De este "instinto del trabajo eficaz" depende la estima social y la honorabilidad. No obstante, en el tránsito del salvajismo a la vida depredadora (siguiente estadio evolutivo), la emulación se abre camino a través de un método distinto. En el estadio depredador merece honor quien accede a los botines codiciados y quien lleva a cabo proezas. El mérito ya no depende del instinto de trabajo eficaz, sino de la lucha, y de la capacidad que se tenga para sacar ventaja de ella. Es en un último estadio, el que coincide con el nacimiento de la "clase ociosa", en el que la forma de destacarse depende del "ocio ostensible". En esta etapa, que según Veblen coincide con el surgimiento de la propiedad privada, el consumo desborda el mero afán de sobrevivencia y comodidad y se convierte en una cuestión de reputación. Para destacarse del colectivo, las capas más pudientes de la sociedad echan mano del derroche, el cual supone "una comparación pecuniaria valorativa" (Veblen, [1899] 2005, 106). De 
este modo, la voluntad de distinguirse del resto, así como la ansiedad por emular a los más distinguidos, serán rasgos antropológicos que recorrerán las distintas etapas de la evolución humana.

Es así como para Veblen el vestido se convierte en un fenómeno de "derroche ostensible" (y por tanto en una suerte de emblema de clase) propio de las sociedades industriales. La prenda de moda es aquella que evidencia que quien la porta no tiene necesidad de emplear su fuerza de trabajo:

[...] los vestidos elegantes sirven a su finalidad de elegancia no sólo por ser caros, sino también porque constituyen los símbolos de ocio. No solo muestran que el usuario es capaz de consumir un valor relativamente grande, sino que indican a la vez que consume sin producir ([1899] 2005, 177).

Nótese cómo la tesis, tan cara a las filosofías de la moda posteriores -particularmente para el estructuralismo, del cual me ocuparé más adelante-, según la cual la moda constituye una suerte de lenguaje (uno que en este caso comunica pertenencia a una determinada clase), encuentra ya en estas primeras teorías su formulación original: solo si concedemos al vestido alguna capacidad comunicante es teóricamente coherente afirmar que una prenda implica prestigio ante los ojos ajenos. En todo caso, lo que interesa subrayar por ahora es cómo dentro de este esquema el aumento de reputación subordina el carácter utilitario de la prenda y la convierte en un símbolo de reputación, lo que hace que aquellos que no poseen estatus lo busquen imitando el modo de vestir de quienes sí lo tienen.

Dado, sin embargo, que según estos autores las modas no tardan en extenderse a través de los emuladores pertenecientes a las clases bajas, rápidamente hay que buscar nuevas prendas que reflejen derroche. Esta dinámica de consumo pone en marcha una contradicción en el ser humano: si el "instinto de trabajo eficaz" (el cual requiere de un rechazo de lo fútil) está inscrito en su naturaleza, ¿cómo es que el derroche ostensible, el cual requiere justamente de lo contrario (del gasto desbordado), es entonces posible? Es en virtud de esta tensión que las modas no dejan nunca de aparentar utilidad. Por más 
absurda que sea una innovación siempre finge algún rendimiento, cumpliendo así con el doble requisito de sugerir suntuosidad pero también provecho. No obstante, en cuanto se hace evidente que la nueva moda está animada, al igual que la anterior, por el mero afán de derroche, se impone la necesidad de crear una nueva moda que disimule mejor su inutilidad.

Para Simmel, el origen de la emulación tiene una génesis acaso más discreta: la imitación no es más "que la hija que el pensamiento tiene con la estupidez" ([1905] 2008, 72). Igualmente inscrita en "las luchas y compromisos, [en] las conciliaciones lentamente logradas y pronto deshechas que tienen lugar entre el impulso a fundirnos con nuestro grupo social y el afán de destacar fuera de él” (Simmel, [1905] 2008, 71-72), la emulación acaece en medio de una batalla que, tal y como ocurre en Veblen, remite al reino de los instintos y conoce de progresos y etapas evolutivas. También en los escritos de Simmel aparece, así, la figura del "hombre teleológico" opuesto al "hombre imitador", oposición correlativa a la vebleana entre quienes actúan con base en el "instinto de trabajo eficaz" y quienes actúan a partir del principio de "derroche ostentoso". No obstante, en Simmel la moda posee otra particularidad: es, a un tiempo, principio de individuación y mecanismo homologador, es decir, genera diferencias entre los individuos y simultáneamente produce obediencia social ([1905] 2008, 82). En este sentido, la moda es también una institución con la doble función de incluir y excluir al individuo del grupo. En el marco de estas oposiciones dualistas entre el "hombre teleológico" y el "hombre imitador", la individuación y la masificación, y el cambio y la permanencia, es que el ya mencionado comentador español de Simmel, Jorge Lozano (2000), ve la teoría del vestido simmeliana como un análisis del atractivo formal de los límites puestos en juego por la moda. La moda sería para Simmel, según Lozano, un fenómeno contradictorio que, al trazar una frontera, participa de los procesos que generan esa contradicción; de ahí su carácter seductor.

Al igual que Veblen, sin embargo, Simmel ve en la moda y en su ritmo trepidante un signo de decadencia social y un síntoma del nerviosismo moderno: “cuanto más nerviosa es una época tanto más velozmente cambian sus modas, ya que uno de sus sostenes 
esenciales, la sed de excitantes siempre nuevos, marcha mano a mano con la depresión de las energías nerviosas" ([1905] 2008, 78). Esta dinámica permea el todo social y es, de hecho, culturalmente administrada: las prendas no se ponen de moda, sino que están diseñadas desde un comienzo para que sean moda. Por lo demás, la lógica interna de la moda es para Simmel circular, de modo que cuanto más cotizada está una prenda más se consume, cuanto más se consume más se abarata, cuanto más se abarata más démodé se vuelve, y cuanto más démodé deviene tanto más rápidamente pasa de moda.

No hay duda de que Veblen y Simmel, influenciados por el aparato categorial marxista (nótese la centralidad que en sus esquemas posee la categoría de clase, así como la distinción entre valor de uso y valor de cambio) son deudores de cierto clima filosófico moderno que empezaba a preocuparse por el dinero, el consumo y los precipitados cambios de ritmo impuestos por las sociedades industriales. Pero más allá de esas coincidencias de los autores con la episteme de su época, cabe reparar en la formación discursiva que estas primeras reflexiones en torno al vestido inauguran, ${ }^{1}$ pues estas marcan buena parte de las ulteriores teorías sobre el vestido y suscitan una serie de réplicas que prolongarán su influencia hasta el presente. La filosofía de la moda es, pues, una formación discursiva cuyo fundamento, según creo, se encuentra en las teorizaciones de Simmel y Veblen, pero que con el tiempo, no obstante, se fue sedimentando no únicamente a partir de los adeptos que despertó, sino también, como mostraré a continuación, de los disensos que suscitó.

\subsection{Detractores y continuadores: los derroteros de la herencia conceptual de Veblen y Simmel}

La teoría de la emulación, tal y como fue formulada por Simmel y Veblen constituye, sin duda, la explicación más retomada acerca de la naturaleza de la moda en tanto problema teórico. No obstante, ello no significa que no haya sido objeto de intentos de

\footnotetext{
${ }^{1}$ Por formación discursiva entiendo, con Foucault, la delimitación de un campo de conocimiento conformado por un objeto de estudio, unos determinados tipos de enunciados, unos conceptos específicos y unas ciertas temáticas (Foucault, [1969] 2007, 50-64), todo lo cual, en el caso que nos ocupa, configura un tipo particular de saber sobre la moda que se recorta sobre un fondo de exclusiones y elecciones teóricas que a menudo operan subrepticiamente.
} 
reformulación e impugnación. La socióloga española Ana Martínez Barreiro y la teórica cultural inglesa Joanne Entwistle señalan, por ejemplo, una serie de limitaciones a dicho modelo (aunque se trata de refutaciones que, como lo probaré más adelante, prolongan en el tiempo el mismo modelo que pretenden descartar). Según dichas especialistas, en efecto, el devenir de la moda a lo largo del siglo XX habría hecho necesaria una reformulación de la teoría de la emulación tal y como la pensaron Simmel y Veblen. Entwistle, haciendo eco de las críticas de diversos teóricos contemporáneos del consumo, subraya el hecho de que la moda, a lo largo del siglo XX, muchas veces fue establecida por las clases bajas y adaptada ulteriormente por las clases altas. En otras palabras, contrariamente a Veblen y a Simmel, la autora considera que las modas se difunden no solo desde "arriba" sino también desde "abajo". Del mismo modo, Entwistle discrepa del criterio según el cual la moda pasa una vez que es popular entre las clases bajas y califica de mecanicista y simplista el modelo de la emulación ([2000] 2002, 74-75). Además, ataca la idea de que las élites que imponen la moda siempre estén marcadas por su condición de clase y critica ciertos supuestos metafísicos subyacentes a las propuestas vebleana y simmeliana, como por ejemplo su utilización del concepto de naturaleza humana (Entwistle, [2000] 2002, 116; retomaré desde mi propia perspectiva esta crítica en el capítulo siguiente). Martínez Barreiro, por su parte, indica que en el marco de las sociedades globalizadas la teoría de la emulación ha perdido vigencia, por lo que propone con Wiswede un desplazamiento a la metáfora de la virulencia, haciendo referencia al modo precipitado en que se propagan actualmente las tendencias vestimentarias. Así, para la autora, la moda sería una suerte de fenómeno de contagio en el sentido de que precipita emulaciones de forma masiva y de que su difusión se da de forma horizontal, propagándose a la manera de un virus y no ya de forma vertical a la manera de una imitación de clase. El ritmo de producción del capitalismo finisecular habría cambiado la lógica del consumo hasta un punto en el que la dinámica de transmisión de las tendencias privilegia una multidireccionalidad antes que una dinámica vertical. La lógica de la confección textil, así como el surgimiento de la publicidad, habrían interferido en la estructura piramidal de clase, necesaria para que la teoría del filtrado descendente siguiera siendo plausible. De modo pues que la tesis de que la moda se explica a partir 
del ocio ostensible sería sustentable solo en sociedades preconsumistas. En este sentido, señala la autora,

[...] para comprender el funcionamiento del sistema de la moda hemos de apartarnos del modelo de "filtrado descendente" que ha supuesto la base de muchas discusiones sobre la moda y su difusión y contemplar la moda como resultado de procesos socioeconómicos más complejos tras el desarrollo de la sociedad de consumo y el impacto de la globalización económica y cultural (Martínez Barreiro, 2006, 191).

Pero estas críticas, pese a su afán de ruptura, tienen más continuidad con Simmel y Veblen de la que parecieran dispuestas a admitir. Cabe argüir, de hecho, que estos últimos autores abren un campo epistémico para analizar la moda que las críticas descritas, así como las diversas teorías de la moda posteriores, de una u otra forma validan. En tal sentido, como lo indica Lozano, "quienes sostienen hoy que la difusión de la moda más que vertical es horizontal, no han conseguido (...) superar en lo esencial el diagnóstico de Simmel” (2000, 241). En las críticas recogidas tanto por Martínez Barreiro como por Entwistle (críticas que, por lo demás, provienen de un espectro muy amplio de autores) una serie de núcleos establecidos por los teóricos de la emulación permanecen de hecho intactos.

Mi hipótesis en este sentido es que el binomio moda-consumo, la preocupación por elaborar una teoría que explique la propensión a la imitación, la inscripción de la moda en un marco de guerra o competencia por la diferencia, y la conexión entre moda e identidad conforman una grilla de inteligibilidad de la que la filosofía de la moda depende todavía. Esta hipótesis puede verse reforzada por el hecho de que la teoría de la emulación, además de resistir a los embates de sus críticos, también ha sido objeto de reformulaciones por medio de una serie de autores que la han adaptado a sus propios esquemas explicativos.

Probablemente la reformulación más importante de esta teoría en el siglo XX la encontremos en los escritos sobre moda de Pierre Bourdieu -aunque también cabe reconocer influencias de dicho enfoque en autores de diverso perfil como la ensayista 
española Margarita Rivière (1977, 44-54), el sociólogo alemán René König ([1958] 1968, 91- 101) o el semiólogo y filósofo italiano Nicola Squicciarino ([1986] 1998, 164-170)-. A través de Bourdieu, probablemente el teórico de la moda más importante desde Veblen y Simmel, la teoría de la emulación se nutre, en efecto, de otras corrientes y lleva a cabo préstamos categoriales de otras matrices analíticas. Para Bourdieu la estratificación de clase que da origen a la moda continúa siendo una clave analítica central. La versión de Bourdieu, no obstante, resulta más refinada que la de sus antecesores en varios sentidos. En primer lugar, para el sociólogo francés la preferencia de unas prendas por sobre otras no obedece a rasgo antropológico alguno, sino a un entramado social y económico que guía esas preferencias. En su más importante obra, La distinción ([1979] 2012), Bourdieu opone a la estética kantiana una concepción sociohistórica del gusto. A saber, mientras que para Kant el juicio estético se define como un juicio a priori que se realiza independientemente de todo interés que no sea la contemplación del propio objeto bello (Kant, [1790] 1961, 47), para Bourdieu el gusto no puede comprenderse por fuera de las condiciones materiales de existencia que lo engendran. ${ }^{2}$ En tal medida, Bourdieu no podrá estar de acuerdo con la explicación antropológica de Veblen según la cual los mecanismos difusores de la moda vienen dados por la tendencia natural del ser humano a la imitación. Para Bourdieu, por el contrario, las preferencias de unas prendas por sobre otras vienen dadas por la clase, entendida no ya a partir de un perfil psicológico o hasta tribal como ocurría en los teóricos de la emulación clásicos, sino como la posición ocupada en el conjunto de las relaciones de producción. Es en ese marco sociohistórico en el que se despliegan las luchas por alcanzar un lugar distinto al ocupado por cada quien a partir de su origen de clase. En dicho marco, pues, Bourdieu ve en las prendas elementos que al "recibir su valor de su posición en el sistema de signos distintivos" (Bourdieu [1979] 2012, 292) funcionan imprimiendo en el cuerpo unos ciertos modos y gestos que denotan la pertenencia a una clase determinada. Como se ve, hay entonces acá una primera complejización bourdieuana del esquema de Veblen y Simmel: ya no se trata, insisto, de una emulación explicada en términos atávicos, sino más bien de una

\footnotetext{
${ }^{2}$ Sobre este asunto véase especialmente Bourdieu ([1979] 2012, 569-586). Otra formulación de dicha crítica se encuentra igualmente consignada en Bourdieu (2011, 238-239). En ambos casos el objetivo del sociólogo francés es refutar el carácter supuestamente asocial de la teoría del juicio estético tal y como la formula Kant en su Crítica del Juicio.
} 
vista a la luz de criterios sociohistóricos. En segunda instancia, Bourdieu modifica el modelo imitativo en la medida en que le atribuye un cierto voluntarismo que choca con el constructivismo propio de su perspectiva teórica -de ahí que el autor hable de la "distinción sin intención de distinción" (Bourdieu, [1979] 2012, 246)-. La preferencia por una determinada indumentaria responde, para Bourdieu, al efecto de una división de clases objetiva: el seguidor de la moda no elige propiamente hablando lo que viste, sino que las estructuras de clase condicionan ( $\mathrm{y}$ a veces determinan) las preferencias vestimentarias de cada quien. Así, no son propiamente las modas las que distinguen a los emuladores de los emulados, sino que :

[...] la lógica del funcionamiento de los campos de bienes culturales y las estrategias de distinción que se encuentran en la base de su dinámica hacen que los productos de su funcionamiento, ya se trate de creaciones de moda o de novelas, estén predispuestos para funcionar diferencialmente, como instrumentos de distinción (Bourdieu, [1979], 2012, 274).

Las modas, así, diferencian a los individuos, pero como efecto especular de una diferenciación objetiva que tiene lugar a partir de un entramado económico que divide a los individuos según su capacidad adquisitiva. Por otro lado, Bourdieu realiza una tercera complejización a la teoría de la emulación: mientras que en el esquema inicial los usuarios de vestidos se dividían entre emuladores y emulados, las búsquedas de distinción se dan para el autor también a lo interno de las fracciones de clase. Así, en el interior de una misma clase se dan una serie de pugnas por el acceso a los bienes simbólicos distintivos -entre los cuales, claro está, el autor incluye la vestimenta- en aras de ascender en la escala social. Para Bourdieu, de este modo, la lucha por la distinción se da no únicamente entre miembros de clases diferentes, sino también entre quienes comparten un mismo estrato social (especialmente en el caso de las clases altas). La búsqueda de distinción, en tal sentido, constituye una dinámica que viene dada por las condiciones materiales de existencia producidas por las diferencias económicas y no por una psicología de clase que compela, a la manera de una esencia antropológica, a unos individuos a imitar a otros. 
En suma, Bourdieu agrega una buena dosis de trabajo de campo y observación sociológica al esquema de Simmel y Veblen; además, realiza el significativo aporte de estudiar el modo en que las prendas, en conexión con las diferencias de clase, impactan la corporalidad (aporte este último que intentaré retomar, aunque desde una perspectiva de género, en capítulos posteriores). No obstante, pese a Bourdieu mismo -quien expresa una voluntad de separase del modelo del filtrado descendiente (Bourdieu, [1979] 2012, 696)-, su empresa pareciera antes un intento de mejorar la teoría de la emulación que una búsqueda por superarla. Si bien Bourdieu no construye específicamente una teoría dedicada a explicar la moda sino que por el contrario la moda constituye para el autor un terreno especialmente fértil para probar su argumento de que el gusto posee una raíz sociohistórica, hay que decir que las observaciones de Bourdieu con respecto a la moda se encuentran ya en ciernes en las teorías de Simmel y Veblen. Específicamente, Bourdieu afirma con estos autores el carácter medular de la imitación dentro de la difusión de las costumbres vestimentarias -y aún más la refuerza, toda vez que extiende el modelo imitativo a las fracciones de clase (Bourdieu, [1979] 2012, 192)-. Al igual que Simmel y Veblen, por otra parte, el sociólogo francés también considera que la moda constituye una institución cuyo mecanismo de base depende del efecto diferenciador propio de ciertas prendas como parte de un afán socialmente generalizado por alcanzar el prestigio (Bourdieu, [1979] 212, 224). Por último, y de nuevo siguiendo a sus predecesores, Bourdieu ve en la moda -a mi juicio restrictivamente- una forma de lujo que acaba en cuanto se ha difundido entre las clases más bajas (Bourdieu, [1979] 2012, 291).

Así pues, en lo tocante a sus opiniones respecto de la moda, considero que Bourdieu puede ser leído como un renovador al tiempo que como un continuador de las intuiciones generales de las teorías de Simmel y Veblen. La sociología de Bourdieu ofrece ciertamente un análisis más situado y crítico que el de sus predecesores al acentuar la influencia de la división social del trabajo en los procesos difusores de la moda, pero al mismo tiempo confirma la centralidad del asunto de la difusión como problemática teórica. En síntesis, puede decirse que Bourdieu da un carácter más riguroso a la teoría de la emulación, pero que, simultáneamente, conserva los núcleos centrales de la misma. 
Con la sociología del siglo XX, por lo tanto, la teoría de la emulación adquiere un cierto rigor conceptual pero también continúa una perspectiva.

Por tanto, más allá de las variantes de acento entre las teorías presentadas en el presente apartado, cabe decir a manera de síntesis que tanto de la mano de los críticos de Simmel y Veblen como de sus continuadores (de los cuales Pierre Bourdieu es un ejemplo privilegiado por la agudeza de su análisis) la teoría de la emulación extendió su influencia a lo largo del siglo XX. De hecho, a partir de dichos aportes es plausible afirmar que la teoría de la emulación abre un pliegue epistémico sumamente seductor para los estudiosos de la moda: en efecto, tan solo 50 años después de su formulación original -la de Veblen y Simmel-, esta ya conocía enmiendas y segundas versiones. Moda, imitación y clase conforman así una triangulación que inaugura las reflexiones filosóficas en torno al vestido y que establece una especie de suelo discursivo para las filosofías de la moda posteriores, no obstante las variantes de acento que estas introducen en dicha formación discursiva.

\subsection{La moda, esa "diosa misteriosa"}

A partir de un marco disciplinar distinto al de los teóricos de la emulación, proveniente del psicoanálisis freudiano, el psicólogo inglés J. C. Flügel escribió en 1930 su paradigmática obra Psicología del vestido. El proyecto de Flügel era abordar el tema de la relación entre la psique, el vestido y el cuerpo echando mano de algunas tesis de la teoría psicoanalítica. Flügel, continuando la tradición abierta por los teóricos de la emulación, encuentra en la vestimenta una forma de comunicación, pero al contrario de dichos autores, no ve en el vestido un lenguaje que comunique contenidos de la consciencia -es decir que no ve en la utilización de prendas de vestir una búsqueda consciente de diferenciación-, sino más bien un canal de transmisión de información inconsciente. Al igual que Veblen y Simmel, Flügel considera que el vestido es comunicativo en razón de la naturaleza instintiva del ser humano. Por este motivo, a la hora de dar cuenta del móvil originario del vestir, Flügel otorga una primacía a la 
necesidad de decoración antes que al pudor, o incluso a la necesidad de protección. Así, según Flügel "hay pueblos que no se visten pero no pueblos que no se decoren" ([1930] 1964, 14).

Alrededor de la naturaleza decorativa de la moda existen, según el fundador de la psicología del vestido, ocho motivos: 1) atraer sexualmente a los de la misma especie, 2) simbolizar una proeza, 3) aterrorizar a los enemigos, 4) mostrar el rango o la ocupación, 5) evidenciar un sentido de pertenencia, 6) ostentar riqueza, 7) utilizar ciertas partes de los vestidos a la hora de portar artículos imprescindibles y 8) aumentar el poder del cuerpo al incrementar el espacio que este ocupa (Flügel, [1930] 1964, 23-42). De este modo, las posibilidades comunicativas del vestido se multiplican, a pesar de que al mismo tiempo se vuelven opacas en la medida en que reflejan contenidos no necesariamente conscientes. La ropa dice ahora más cosas, pero de manera más difusa. Así como existen distintas formas de decoración, también existen distintos impulsos inhibitorios o represores, dado que la decoración y el pudor no son sino dos formas opuestas de satisfacer una misma pulsión: atraer la atención de otros (en el primer caso de manera voluntaria y abierta, en el segundo de manera solapada). Por último, al lado del pudor y la decoración, la protección sería el último fenómeno en importancia involucrado en la utilización de vestidos, ya que según el autor la antropología habría demostrado que en condiciones atmosféricas adversas algunas culturas han sobrevivido sin necesidad de utilizar ropa. La protección, en opinión de Flügel, se aplica tanto contra amenazas ambientales -por ejemplo el frío- como contra enemigos específicos -ya sean humanos o animales-. Por otra parte, también existen formas de protección contra factores psicológicos, ya sean de carácter mágico/espiritual, moral o bien "contra la hostilidad general del mundo en su conjunto" (Flügel, [1930] 1964, 99). ${ }^{3}$

Según la psicología del vestido del teórico inglés hay además una serie de reacciones humanas distintas a la imposición social de llevar vestidos. En un espectro que va desde los sujetos que asumen más alegremente las represiones generadas por las prendas hasta

\footnotetext{
${ }^{3}$ Barthes critica la gratuidad de este tipo de aseveraciones calificándolas de "sumaria[s] y estrictamente analógica[s]" $(2003,369)$. En el apartado siguiente me detendré a examinar la relación de la filosofía de la moda barthesiana con la teoría de Flügel.
} 
quienes se rebelan a las molestias producidas por ellas, Flügel establece toda una tipología clasificatoria de los sujetos portadores de prendas. El criterio de dicha tipología es el grado de narcisismo autoerótico con el que se portan las ropas. Mientras que un extremo encontramos al tipo rebelde cuyo "erotismo muscular" -el cual designa la obtención de placer a través "del libre juego de los músculos" (Flügel, [1930] 1964, 113) - y cutáneo -el cual alude al placer obtenido por la dilatación y el relajamiento de la piel- se encuentran inhibidos por la vestimenta en uso, en el otro tenemos a quienes logran sublimar dicha represión y disfrutan de portar ciertas prendas. De este modo, para Flügel, el cuerpo desnudo constituye una fuente de placer autoerótico que la vestimenta reprime, pues según el autor la necesidad de protegernos del frío proviene de nuestras fantasías intrauterinas. La necesidad de abrigo se remonta a la sensación originaria de calidez y protección originalmente generada por el útero materno.

Flügel también se explaya en consideraciones a propósito de la función que el vestido posee en términos de diferenciación de los cuerpos femeninos y masculinos. En su opinión, la ropa juega un importante rol en lo tocante a la comunicación del sexo que cada quien ofrece a los otros. Al margen de algunas excepciones como la del eonismo, la ropa eliminaría las ambigüedades y los engaños, fijando a los ojos de los demás a qué sexo se pertenece (retomaré este asunto en la segunda parte de este trabajo). A pesar de las diferencias culturales, pues, el vestido habría tenido entonces la tarea histórica de facilitar la identificación de varones y mujeres (volveré reiteradamente sobre este asunto en instancias posteriores; véase especialmente el capítulo 4).

Por otra parte, la filosofía de la moda de Flügel resulta novedosa en un aspecto: contrariamente a los autores antes expuestos, propone una ética del vestido. Mixturando la psicología freudiana con una curiosa versión de hedonismo utilitarista que promulga el uso de las prendas cuanto mayor comodidad y placer físico estas nos proporcionen, Flügel concluye su texto con una especie de utopía vestimentaria. En aras de evitar la incomodidad y el encorsetamiento del cuerpo, el autor arguye la deseabilidad de unas ciertas juntas consultivas que establecerían cuáles prendas son más útiles y bellas (Flügel, [1930] 1964, 286-287). Se trata de una suerte de relevo de los modistos por un comité 
cuyo criterio sería independiente de intereses económicos y estaría más bien orientado por la premisa de liberar el cuerpo (pero que paradójicamente funcionaría con el mismo grado de normatividad con el que funciona la moda creada por los diseñadores que Flügel critica). Dichas juntas, no obstante, no serían más que una institución transitoria, pues en una sociedad enteramente liberada de la moda lo que prevalecería sería un nudismo utilitarista que dejaría al cuerpo a sus anchas por completo. Mientras se camina hacia ese objetivo último de la desnudez total, Flügel propone que

[...] el objetivo de las ropas debería de ser asegurar el máximo de satisfacción de acuerdo con el "principio de realidad" (es decir, el principio de basar nuestras satisfacciones en un reconocimiento fundamental del mundo real, y no en una distorsión de él o una negación de sus principios menos agradables) ([1930] 1964, 17).

No obstante el talante hasta cierto punto renovador de Flügel, este texto fundacional de la psicología del vestido coincide con la tradición en la centralidad que atribuye al problema de la difusión de la moda; su respuesta a tal problema, de hecho, es idéntica a la de la tradición: la moda subsiste en virtud de ese rasgo antropológico que es la imitación. Apenas y vale la pena detenerse en esta versión psicológica de la tesis vebleano/simmeleana examinadas más arriba. En ella, de hecho, encontramos el mismo tipo de postulados e incluso idénticas imágenes: la moda aparece como propiedad exclusiva de las sociedades no primitivas, se difunde "hacia abajo" (aunque hay que reconocer que para el autor ese argumento admite excepciones en unos pocos casos) y subsiste gracias al encantamiento estético que produce lo nuevo en tanto mecanismo distintivo. Aún cuando el autor reconoce un cierto protagonismo a factores sociológicos en la producción de moda (como la aparición de una industria capaz de producir masivamente, el surgimiento de medios de transporte y distribución, la importancia relativa- de los modistos, y, sobre todo, la atribución de una influencia del Zeitgeist en la creación y difusión de las modas), la dimensión sociológica de su análisis da preeminencia a los motivos de la imitación y allí sus respuestas replican la atmósfera y el sentido de las respuestas simmeliana y vebleana. Tanto para los teóricos de la emulación, como para la psicología del vestido la moda tendrá entonces lugar en un campo de batalla 
y su motor será igualmente el consumo, o si se quiere, la búsqueda de una diferenciación de orden antropológico.

Ahora bien, la filosofía de la moda de Flügel plantea un problema que se halla en ciernes tanto en la filosofía de Simmel como en la de Veblen. Se trata del siguiente: si en la utilización de prendas hay un impulso psicológico que lleva a los seres humanos a buscar distinguirse, es porque la moda constituye un lenguaje, un símbolo distintivo. En lo referente a la codificación de ese lenguaje, cabe formular, por tanto, la pregunta de si dicha codificación es inmanente a un sujeto que atendería sencillamente a mandatos psicobiológicos -en cuyo caso las prendas significarían siempre en función de una psique que las interpreta-, o si le viene dada por condiciones culturales externas a él -en cuyo caso la legibilidad simbólica de las prendas es socialmente gestionada-. Flügel, aún con oscilaciones, se inclinará por responder lo primero - de ahí que hable de la moda como una "diosa misteriosa" ([1930] 1964, 179) hundida en las profundidades de una psique nunca enteramente descifrable-. El estructuralismo, por su parte, heredará el problema, pero tomando la vía alternativa.

\subsection{El estructuralismo y "la máquina de hacer moda"}

Entre 1957 y 1967 el filósofo y semiólogo francés Roland Barthes escribió un conjunto de artículos y un libro a propósito de la vestimenta y su capacidad de significación retomando algunos de los problemas que habían dejado planteados sus predecesores. Su filosofía de la moda se inscribía en un proyecto de dimensiones amplias: se trataba de realizar análisis semiológico/estructuralistas aplicados a ámbitos distintos a las ciencias sociales y la lingüística. Para entonces, los estructuralistas buscaban expandir su radio de acción convencidos de que, en tanto ciencia de los signos, la semiología tenía posibilidades de aplicación a múltiples fenómenos sociales (la ropa, la comida, la vivienda, etc.). En este marco, Barthes se traza el objetivo de realizar un "análisis estructural del vestido femenino tal y como (...) se describe en las revistas de Moda" ([1967] 2003a, 11). 
Aún cuando este análisis bien podría haber desembocado en un estudio de la moda en su dimensión material, la prioridad de Barthes era más bien crear un sistema explicativo estrictamente formal en el que se "establec[iese] una estructura general, capaz de explicar todos los enunciados de moda, sin importar cuáles [fuesen sus] contenidos" ([1967] 2003a, 71). Por este motivo, para algunos teóricos El sistema de la moda ([1967] 2003a), en tanto libro sobre la vestimenta, no deja de ser delusorio en la medida en que por momentos el objetivo de mostrar la aplicabilidad de la semiología al ámbito del vestido pareciera más importante que el análisis del fenómeno vestimentario propiamente dicho. Es la opinión, por ejemplo, de Guillaume Erner, quien señala que el Sistema de la moda es una "obra de título engañoso, ya que trata más el discurso consagrado a la moda, que la moda en sí" ([2005] 2010, 207). La teórica cultural Elizabeth Wilson califica asimismo la obra de Barthes como "decepcionante" y añade que no se trata, en realidad, de "un libro sobre moda. Trata en cambio, ciertos aspectos del periodismo especializado en la moda" (Wilson, 2001, 289).

Sin embargo, una lectura cuidadosa de sus textos revela que más allá del éxito de Barthes a la hora de explicar el funcionamiento formal de las revistas de moda (tarea que ocupa la mayor parte de su trabajo), lo cierto es que el autor no deja de justificar sus elecciones metodológicas ni de proponer un tipo de acercamiento teórico al asunto del vestido. En esta medida, creo que cabe leer a Barthes como un filósofo de la moda, aún cuando en primera instancia sus obras sobre el tema parecieran interesadas sobre todo en realizar ejercicios de semiología aplicada.

¿Qué es entonces para Barthes la moda? Si las prendas son susceptibles de analizarse a la luz de una teoría de los signos (tal y como habían dejado sentado ya Veblen y Simmel y había ratificado Flügel), en opinión de Barthes la moda tendría que considerarse un lenguaje articulado. Para Barthes, Flügel es en este sentido un autor fundamental, en la medida en que fue el primero en haber analizado la moda como una forma de expresión ( sin embargo, tal y como apuntaba supra, cabe pensar que la moda ya expresaba algo para Simmel y Veblen, a saber: la voluntad de algunos individuos de distinguirse de 
otros, o en su defecto, la voluntad de los segundos de igualarse a los primeros). En tal sentido es que Barthes habla de una máquina de hacer moda: "bastaría construir una memoria matemática (en forma de una máquina de hacer moda), para que la moda, incluso a escala de una microdiacronía, apareciese como un orden de formas limitadas y esencialmente computable" ([1960] 2003, 395).

Alrededor del vestido sería entonces posible identificar una serie de estructuras que interactúan y crean toda una "mitología", la cual consiste en presentar prendas que forman parte de una semiología socialmente construida por la moda como si fuesen naturalmente atractivas. Para Barthes, contrariamente a lo propuesto por Flügel, lo que la moda comunica es un leguaje estructurado que el sujeto se limita a adoptar, otorgándose así, de nuevo, pese al énfasis semiótico de Barthes, una centralidad primordial al asunto de la difusión. En otras palabras, la moda constituye para este autor un sistema cuya estructura debe estudiarse para develar el modo en que se presenta como un ámbito de fantasía y libertad, cuando en realidad se trata de un fenómeno de consumo previa y detalladamente codificado. Esta codificación se da en los distintos niveles estructurales distinguidos por el autor. Así, existe una codificación tanto en el plano material o tecnológico - en la medida en que en la confección de prendas hay una materialización de una estructura que pauta su fabricación-, como a nivel del vestido descrito (o verbal) y del vestido fotografiado en las revistas de moda. Son estas codificaciones $-\mathrm{y}$ no ninguna dinámica aleatoria- las que inducen el anhelo de adquirir una prenda, de modo que según Barthes "lo que suscita el deseo no es el objeto sino el nombre [y] lo que vende no es el sueño sino el sentido" ([1967] 2003a, 21).

Con el afán de mostrar cómo la moda construye ese sentido que seduce - $\mathrm{o}$ en palabras llanas, cómo es que la moda se difunde-, el autor elige dejar de lado lo que denomina el "vestido real" (es decir, el vestido portado por alguien, tarea que, como se verá, retoman algunos de sus sucesores) y se concentra en analizar el vestido tal y como se presenta en las revistas de moda. Aún más, por manifestarse esta codificación estructural de una manera más sencilla de aprehender en el "vestido descrito" que en el "vestido fotografiado", su análisis se centra exclusivamente en el primero, delegando así la 
responsabilidad de realizar un análisis estructural del "vestido real" a los etnólogos. En otras palabras, Barthes elige analizar exclusivamente el vestido descrito por las revistas de moda pues es allí donde encuentra que la pureza estructural del fenómeno vestimentario se revela con mayor claridad (no porque considere, cabe señalar, que esa naturaleza estructural del discurso de moda no sea trasladable a la indumentaria tal y como se porta cotidianamente).

Partiendo del lingüista ruso Trubetskoy, el filósofo francés diferencia en esta línea los hechos de vestuario de los hechos de indumentaria. Mientras los primeros remiten a las particularidades que un vestido adquiere en el plano de lo individual -grado de desgaste, suciedad, gestos de uso del portador, elección del color, etc.- los segundos son más bien abstractos y refieren a convenciones sociales -usos fijos, gestos estereotipados, reglamentación en el uso de prendas internas y externas, congruencias e incompatibilidades en el atuendo, etc.- (Barthes, [1967] 2003a, 354-357). Esta distinción, paralela según Barthes a la que la lingüística establece entre el habla y la lengua -siendo que la segunda constituye un sistema formal de reglas mientras que la segunda consiste en una puesta al día o actualización de esas reglas (Barthes, [1967] 2003a, 35-36)-, asume que la reglamentación en el plano de la indumentaria es la que determina los hechos de vestuario. En otras palabras, el lenguaje de las revistas de moda, al incorporar en un código específico (el código de moda) ciertas prácticas vestimentarias, dota estas últimas de una coherencia estructural. Esa coherencia estructural se presenta con una retórica prescriptiva y es precisamente de esa forma es que la moda se convierte en ideología.

Así, Barthes critica la psicología de la moda por ver en el uso de vestidos la expresión de una interioridad: "el vestido no es más que el significante de un único significado principal, que es el modo o grado de participación del portador" ([1957] 2003, 360). De esta manera, "si la moda nos parece imprevisible es porque nos situamos en el plano de la reducida memoria humana [pero] en cuanto aumentamos su dimensión histórica encontramos una regularidad muy profunda" (Barthes, [1967] 2003b, 430). La moda es entonces un sistema de codificación de las prendas con un potencial prescriptivo derivado 
de su retórica, y la labor de la semiología estructural sería develar y criticar el carácter "mitológico" de dicha codificación prescriptiva:

[...] la estructura combinatoria de la Moda es transformada míticamente en fenómeno gratuito, en creación intuitiva, en proliferación irreprimible, [pero] una vez más (...) el mito invierte con gran precisión la realidad: la Moda es un orden convertido en desorden (Barthes, [1967] 2003a, 338)

Jean Baudrillard retoma esa labor de decodificación del sistema de la moda en lo que constituye una segunda versión de la reflexión semiológica en torno a la moda. En esta segunda versión, sin embargo, Baudrillard intentará desmarcarse de la filosofía de la moda de Veblen y Simmel. Específicamente en El intercambio simbólico y la muerte ([1976] 1980), el autor combina el estructuralismo de Barthes con una perspectiva posmoderna. La tesis principal de Baudrillard es que la moda busca totalizarse en la medida en que, en ella, todos los signos son intercambiables, razón por la cual cualquier cosa es susceptible de convertirse en moda. En ese universo de la equivalencia general de las formas, aquello que se imita ya no es producido, sino únicamente reproducido. De este modo, no se emula más a un modelo concreto (a un miembro de una clase), sino a una especie de modelo arquetípico de carácter únicamente formal. Puntualmente se imita ya no a la personas de la alta sociedad, sino a maniquíes, toda vez que "los signos no hacen más que segregar lo real y el referencial como un supersigno" (Baudrillard, [1976] 1980, 110). En una palabra: "el cuerpo se vuelve medio de la moda" (Baudrillard, [1976] 1980, 111). Acá el código se ha independizado ya de los cuerpos (cosa que no ocurría de manera total en el estructuralismo barthesiano): la moda funciona así a la manera de un suprareferente meramente formal, razón por la cual el autor llega a la apocalíptica conclusión de que "no podemos escapar a la moda" ([1976] 1980, 115), en la medida en que el código que ella impone es autorreferencial (Baudrillard, [1968] 2007, 174-176). Si bien ya Barthes había señalado que "como la lógica, la Moda se define por la variación infinita de una misma tautología" ([1967] 2003a, 324), en su versión posmoderna del estructuralismo barthesiano, Baudrillard exagera esa dimensión autorreferencial de la moda y postula una estructura que funciona al margen de los cuerpos que la actualizan, de modo que estos se desdibujan casi por completo, perdiendo así su materialidad. 
Otros autores y autoras también han partido del enfoque estructuralista de Barthes para analizar la moda. La teórica de la moda Regina Root, por ejemplo, ha aplicado la filosofía de la moda barthesiana dentro de una perspectiva histórica para analizar algunos episodios de la historia de la moda en América Latina (Root, 2002). Según la autora, una interpretación barthesiana de la moda cuenta con la ventaja de que facilita el análisis de documentos históricos referidos a la moda, además de que posibilita la puesta en tensión de las retóricas de las revistas de moda con los circuitos de recepción de las mismas. Patrizia Calefato, semióloga italiana, retoma, por su parte, la idea barthesiana de que la moda es un sistema de signos e intenta analizar el vestido como un lenguaje no visual. Ya no concentrándose en el "vestido descrito", sino en el "vestido real", Calefato afirma que la moda es el conjunto de regulaciones que pesan sobre los individuos a partir de un cierto orden sociocultural (Calefato, 2001, 214). Mientras que para Barthes la corporalidad quedaba marginada en función de subrayar el modo en que se articulan las estrictas codificaciones vestimentarias en las revistas de moda, para la autora, al cubrirse con vestidos, el individuo percibe y comunica y por lo tanto "hace del sentido propiedad común” (Calefato, 2001, 223). El teórico italiano Ugo Volli también discute críticamente el estructuralismo de Barthes pero suscribe algunas de sus tesis semiológicas, llegando a la conclusión de que la moda es un mecanismo de metacomunicación. Si bien, según Volli, "el vestuario tiene un carácter comunicativo bastante elemental y primitivo" (Volli, 2001, 67), lo cierto del caso es que la ropa juega un importante rol a nivel de seducción. De modo pues que el vestuario forma parte de un circuito comunicativo no como leguaje hablado, sino más bien en el nivel de lo que el autor llama "comunicación seductora" (Volli, 2001, 67). Una última versión de esta filosofía de la moda, quizá en su versión más simplificada -casi divulgativa- se puede ver en el libro de Alison Lurie, en el que el estructuralismo barthesiano es reducido a un análisis de la moda en tanto léxico. Para Lurie, si la moda es un lenguaje, es posible llevar la analogía hasta sus últimas consecuencias e indagar la historia de la moda como si se tratara de la puesta en escena de esa analogía primaria: ciertas prendas serían substantivos, mientras que ciertas otras (por ejemplo los accesorios) serían adjetivos, y así sucesivamente con el resto de prendas y elementos de la lengua. Lurie señala que Barthes no llegó "a poner de manifiesto lo que 
parece obvio: que si la indumentaria es una lengua, debe de tener un vocabulario y una gramática como el resto de las lenguas" $(1994,22)$, de modo que asume como suya esa tarea que el estructuralismo habría dejado pendiente. ${ }^{4}$

En todo caso, y más allá de lo variopinto de estas versiones de la semiología barthesiana, importa señalar que el estructuralismo funda un tipo de aproximación a la moda que refuerza la intuición de Simmel y Veblen según la cual la moda es una forma de lenguaje. De ahí que el estructuralismo de Barthes haya sido objeto de esas distintas recuperaciones manteniendo sin embargo un núcleo común, a saber, la idea de que es posible leer la vestimenta como un código. ${ }^{5}$ La moda, así, alcanza con el estructuralismo y con los autores que sin inscribirse en dicha escuela replican su perspectiva, el estatuto de un lenguaje.

A manera de recapitulación, cabe argüir que el núcleo central de la filosofía de la moda estructuralista continúa una línea que inauguran Veblen y Simmel y que Flügel retoma. Cuando el estructuralismo semiológico quiere ir más lejos de un análisis meramente formal retorna a la idea de la emulación; también para Barthes "la moda es, en efecto, imitación colectiva de una novedad regular" ([1962] 2003, 406). La filosofía barthesiana busca diferenciarse de los primeros teóricos de la emulación señalando que la imitación está motorizada por las revistas de moda y no por el criterio de clase. En tal sentido, para Barthes la moda despierta adhesiones pero ya no de clase; alrededor de ella, asimismo, existe una búsqueda de prestigio pero ya no pecuniario. Las tesis de Barthes, así, constituyen una variación de la teoría del filtrado descendiente, pero en ningún sentido una impugnación de la misma. Otro tanto podría decirse de Baudrillard, quien aún cuando pretende variar el eje de análisis en relación con las primeras reflexiones sobre la

\footnotetext{
${ }^{4}$ Cabe señalar, sin embargo, que la autora no toma nota de la advertencia de Barthes según la cual "la semiología del vestido no es de orden léxico sino sintáctico" ([1959] 2003, 372). En esta medida, al concentrarse en la analogía prenda-palabra, Lurie saca conclusiones pintorescas pero sin sustento teórico: así como hay palabras arcaicas habría modas arcaicas, así como existen distintos dialectos existirían distintas modas culturales, así como hay malas palabras hay prendas mal vistas, etc.

${ }^{5}$ Incluso autores no estructuralistas acaban llevando a cabo análisis que ponen en marcha el esquema de base de dicho enfoque. Así, por ejemplo, los filósofos canadienses Joseph Heath y Andrew Potter, quienes ven en la moda más bien un síntoma de alienación consumista, afirman que "la ropa siempre se ha usado como medio de comunicación. La función simbólica de la ropa se parece mucho a un lenguaje, con una gramática o sintaxis que nos permite expresarnos" (Heath y Potter, [2004] 2005, 189).
} 
moda, sigue inscribiéndose en la tradición inaugurada por Simmel y Veblen al poner en el centro del problema de la moda el asunto de la difusión y su dinámica emulativa. Ciertamente, considero que el hecho de que la comprensión baudrillardeana haga desaparecer los cuerpos y realice una hipostasiación del signo, no quiere decir que la moda sea para él menos imitativa, sino únicamente que la imitación dejó de ser un rasgo de clase para inscribirse en una metafísica de la estructura en la que la emulación no obedece a decisión humana alguna, sino únicamente a una inercia formal. De este modo, el análisis estructuralista de la moda ofrece una explicación distinta sobre porqué se genera la imitación - la cual aparece emparentada con las revistas de moda y la adhesión irreflexiva a códigos estéticos-, así como una hipótesis diferente respecto al origen del afán de distinción -el cual ya no se regirá más por la clase, en virtud de que se ha institucionalizado-, pero mantiene intacto el campo epistémico abierto por Simmel y Veblen. ${ }^{6}$

Por otra parte, considero que si el estructuralismo exageró el peso de las determinaciones estructurales del sistema de la moda, es solo porque hereda el problema que la psicología del vestido de Flügel, así como las teorías de Veblen y Simmel, habían dejado planteado, a saber: ¿qué dota de sentido a la moda en tanto lenguaje o forma de comunicación? Lo que hay en este respecto entre la filosofía de la moda estructuralista y la psicología del vestido, a mi juicio, no es entonces sino un movimiento pendular: mientras para Flügel la moda, en tanto lenguaje, es el reflejo de una interioridad marcada por la naturaleza instintiva del ser humano, para Barthes, la codificación de ese lenguaje es "mitológica", en el sentido de que es establecida por un afuera del sujeto (las revistas de moda). Se trata, sin embargo, de diferencias de acento, dado que para Barthes, de hecho, con Flügel

[...] por primera vez el vestido se libera del triángulo de las motivaciones (protección, pudor, adorno) en el que había sido encerrado, y accede al estatuto de mensaje, de elemento de un sistema semiológico: en este sentido, y pese a su obediencia estrictamente analítica, Flügel hace del vestido mucho más una comunicación que una expresión ([1967] 2003a, 376).

\footnotetext{
${ }^{6}$ Para otra forma de leer en forma complementaria el enfoque estructuralista y la teoría del filtrado descendente, véase Calefato $(2007,36)$.
} 
Flügel y Barthes coinciden así en lo esencial: consideran la moda un lenguaje y al sujeto que la porta una suerte de hablante de ese lenguaje; si los condicionamientos a ese hablante vienen dados por una codificación ideológica externa al sujeto o por unos condicionantes psicobiológicos es lo que partirá las aguas entre el enfoque psicoanalítico y el estructuralismo. Pero como se ve, se trata de una diferencia que deja intacto el fondo.

De este modo, una arqueología de la moda - en el sentido foucaultiano de esta expresión, es decir, en el sentido de una reconstrucción de las estructuras discursivas que hacen posible un saber determinado- podría reconocer hasta aquí tres momentos argumentativos. En el primero, la moda aparece como resultado de unos instintos que llevan a algunos seres humanos a querer distinguirse de los que pertenecen a estratos inferiores. En el segundo, la imitación ya no está determinada sociobiológicamente, sino por una estructura psicobiológica que es la que determina las preferencias referidas a la vestimenta. Finalmente, en un movimiento pendular, el estructuralismo explicará la imitación como un fenómeno de adhesión a una codificación externa al sujeto. En este sentido, considero que la tesis de Flügel, tan subrayada más tarde por Barthes, se limita a explicitar lo que Simmel y Veblen consideraban tan obvio que simplemente daban por sentado: si la moda suscita el deseo de imitar es porque comunica riqueza y prestigio.

No obstante, el campo epistémico abierto por las teorías clásicas de la moda tiene aún una versión más. Se trata de las teorías filosóficas que ponen su acento en la pertenencia de la moda a una época y un contexto específicos: la era moderna y las flamantes sociedades de consumo.

\subsection{Moda, modernidad y consumo}

El imperio de lo efimero ([1987] 2009) de Gilles Lipovetsky -una de las obras más difundidas en lo que a estudios de la moda se refiere- intenta hacer un punto y aparte con las teorías de la moda anteriormente expuestas. Arraigado en un individualismo a 
ultranza, el estudio de Lipovetsky niega la pertinencia de leer la historia de la moda en clave de lucha entre las clases y hace del individuo y su gusto por el capricho el motor de la moda:

[...] la moda no es el corolario de la conspicuos consumption y de las estrategias de distinción de clases, sino que lo es de una nueva relación de cada cual con los demás, del deseo de afirmar una personalidad propia, que se difundió en el transcurso de la Edad Media entre las clases elevadas ([1987] 2009, 66).

Según Lipovetsky, lo que comenzó siendo un privilegio de las clases aristócratas terminó extendiéndose a todo el cuerpo social no por efecto de la imitación de clase -postura teórica a la que el autor se refiere en términos de un "inconsciente epistemológico del discurso sobre la moda" ([1987] 2009, 66)-, sino porque con la modernidad se otorga un inusitado valor a la individualidad. La moda es para Lipovetsky, por definición, el cambio trepidante, la innovación permanente, y las condiciones económicas necesarias para la instauración y reproducción de tal ritmo serían exclusivas de nuestra época. Lo propio del enfoque de Lipovetsky, por tanto, consiste en señalar que en oposición a una premodernidad presuntamente regida por el quietismo y la permanencia de las formas, la modernidad habría posibilitado el ascenso de la individualidad. En términos generales, el error de la teoría de la emulación consistiría en creer que la verdadera razón del consumo de moda es el afán de fundirse con la masa cuando, en opinión del autor, lo que alienta la difusión de modas es en verdad esa particular forma, tan propia de nuestra época, de utilizar la ropa de lujo para "personalizar la apariencia" (Lipovetsky, [1987] 2009, 66).

Para este autor la moda nace, de hecho, como una necesidad de estilización personalizada, por lo que cabe distinguir varios períodos dentro de una cronología de nuestro fenómeno. Su génesis, en efecto, podría remontarse al siglo XII con el ideal de la vida caballeresca -el cual implicaba un "lenguaje cuidado, (...) buenas maneras, (...) cualidades literarias, (...) afectación galante $[\mathrm{y}]$ amor (...) por los objetos bonitos" (Lipovetsky, [1987] 2009, 69)-, pero su verdadero desarrollo se da entre los siglos XIV y XIX y su consolidación apenas y data del siglo XX. Al lado del ideal caballeresco y su 
búsqueda de personalización en el siglo XII, se gesta entonces una especie de protomoda que el autor plantea como una primera etapa en la historia de la moda.

Una segunda etapa, a la que Lipovetsky denomina moda centenaria -por efecto de su proclividad a la estabilidad (Lipovetsky, [1987], 76)- se ubica a mediados del siglo XIX. Dicha etapa se caracteriza por la emergencia de la Alta Costura y la confección industrial, y podría definirse como el umbral de la moda, dado que esta última estallará únicamente, según el filósofo, a partir de lo años 60 con la entrada en pleno de las sociedades de consumo. Se trata de un período en el que se dan las condiciones para una confección masiva de prendas pero que simultáneamente invita a la búsqueda de una individualidad que no obstante debe permanecer a lo largo del tiempo. En esta segunda fase de la historia de la moda se da la convergencia de dos formas de vida divergentes e incluso encontradas: la de la aristocracia elitista con sus valores de suntuosidad y lujo, y la democrático-individualista, la cual, a la larga, se terminará imponiendo sobre la primera (Lipovetsky, [1987], 76-118).

Una tercera etapa es la de la moda abierta, la cual tendrá lugar a partir de la década de los 50. Lo que caracteriza esta tercera etapa "es la autonomización del público frente a la idea de tendencia y la caída del poder de imposición de los modelos prestigiosos" (Lipovetsky, [1987] 2009, 159), proceso ligado de forma fundamental a la aparición del prêt-à-porter. Según Lipovetsky, es en esta etapa (que en términos cronológicos llega hasta el presente a pesar de ser conceptualmente diferenciable de la cuarta y última etapa) más que en cualquiera de las anteriores, en la que el modelo explicativo de las filosofías de la moda clásicas se revela insuficiente. Según el autor "hoy no queremos tanto suscitar la admiración social como seducir y estar cómodos, no tanto expresar una posición social como manifestar un gusto estético, y no tanto significar una posición de clase como parecer jóvenes y desenvueltos" (Lipovetsky, [1987] 2009, 59).

Finalmente, Lipovetsky distingue una cuarta etapa: la de la moda plena, coincidente con el afianzamiento de las sociedades de consumo. En esta etapa la moda extiende su influencia a prácticamente toda la cultura, creando una "fiebre consumista" ([1987] 2009, 
193). En síntesis, para este autor, la moda aparece como un asunto propiamente moderno que depende del individualismo y de la aparición de una industria capaz de producir objetos de consumo de forma masiva.

A partir de esta periodización Lipovetsky intenta distanciarse explícitamente de la tradición abierta por los estudios clásicos sobre la moda. Su tesis general en contra de la teoría de la emulación consiste en señalar que la moda, lejos de ser un asunto de imitación, es una institución exclusivamente moderna en la que se entroniza lo efímero, lo superficial y el consumo de individuos libres. Si bien el autor concede a los textos clásicos que la moda es un problema de consumo (y por lo tanto otorga al asunto de la difusión el mismo lugar privilegiado que sus antecesores) Lipovetsky niega que dicho asunto deba enmarcarse dentro de un contexto de lucha por las diferencias ([1987], 2009, 10). Asimismo, matiza la tesis de que detrás del consumo haya un asunto de competencia de castas y afirma que si bien la moda está asociada con la identidad, ésta no tiene que ver nada con el elemento de clase sino más bien con una búsqueda individual intrínseca al período moderno (Lipovetsky, [1987] 2009, 62-64).

No obstante, considero que, leído con detenimiento, El imperio de lo efímero es una vez más un texto continuador de las teorías clásicas. Su individualismo, en efecto, no hace más que llevar hasta las últimas consecuencias una de las tesis de la teoría de la emulación: la de que los individuos -en Veblen y Simmel, específicamente los individuos aristócratas- están en una búsqueda permanente de distinción social (rasgo sintomático de una filosofía que simula ver en la sociedad moderna una donde todos gozan de los mismos privilegios antaño exclusivos de la aristocracia). En efecto, creo que Lipovetsky coincide en lo esencial con la tradición que critica: en su opinión, de hecho, el problema de la difusión y el modelo imitativo definen los contornos de la moda en tanto problema filosófico. De nuevo se trata más de una variante del vetusto modelo imitativo creado por Simmel y Veblen que de una impugnación del mismo:

[...] ya no imitamos lo superior, imitamos lo que vemos alrededor, los modos de vestir simples y graciosos, los modelos asequibles que se presentan cada vez más en las revistas. La ley de imitación vertical ha sido sustituida por una imitación 
horizontal en conformidad con una sociedad de individuos reconocidos como iguales ([1987] 2009, 169).

Al desconocer la diferencia de clases presente en Veblen y Simmel, sin embargo, el esquema de Lipovetsky queda desprovisto de uno de los dos motores que según los autores clásicos impulsaba el cambio en las costumbres vestimentarias, razón por la cual el autor tiene que exagerar el protagonismo de una vanguardia que se ha quedado sin imitadores. Al afirmar el autor que todos los individuos están avocados a distinguirse de todos los demás, su filosofía de la moda no ha superado en modo alguno la de aquellos a quienes comenta; de hecho, en cierto sentido, podría decirse que la suya no es sino una versión empobrecida de las teorías que critica.

Por ejemplo, Lipovetsky substituye el modelo vebleano de la diferencia de clases como combustible de la moda por la idea de que la moda se alimenta a partir de un "sistema de pequeñas diferencias" (Lipovetsky, [1987], 2009, 183). En su opinión, el consumo exasperado de las sociedades contemporáneas no tiene que ver tanto, por ende, con la mirada ajena: consumimos en búsqueda de un bienestar y un placer propios (Lipovetsky, [1987], 2009, 196). Así, el filósofo concluye que la difusión de las modas se da por efecto de un individualismo hasta cierto punto independiente de la posición social:

[...] a través de las marcas consumimos dinamismo, elegancia, potencia, esparcimiento, virilidad, feminidad, edad, refinamiento, seguridad, naturalidad y tantas otras imágenes que influyen en nuestra elección, que sería simplista hacerla recaer sobre el solo fenómeno de la posición social, precisamente cuando los gustos no cesan de individualizarse (Lipovetsky, [1987] 2009, 198).

Sin embargo, este intento de desocializar el consumo -Lipovestky afirma expresamente que la modernidad pone en marcha una "desocialización del consumo" (p. 195)- está, a mi modo de ver, condenado al fracaso: el dinamismo, la elegancia, la potencia, etc. son todos valores culturales e históricos. En ese sentido, el imaginario de la lucha por la diferencia sigue, en mi opinión, dotando de legibilidad a la filosofía de la moda de Lipovetsky: si bien la moda no escenifica un combate por la distinción social, lo cierto 
del caso es que en ella cada quién persigue "la afirmación individualista de la autonomía privada" (Lipovetsky, 2007, 198).

Lipovetsky, en mi opinión, acaba entonces suscribiendo la hipótesis de la emulación e inclusive llevándola aún más lejos que sus propios defensores:

[...] el régimen de la imitación global y cerrada propio de los períodos de tradición ha sido sustituido por el de la imitación individual y parcial. Se imita esto y no aquello, de éste se copia esto, de otro aquello; nuestros préstamos carecen de un origen determinado, son tomados de innumerables fuentes. Lejos de ser equivalente a la uniformización de los comportamientos, usos y gustos, el imperio de la moda conlleva la personalización de los individuos. En las épocas de tradición, se imita a pocos hombres, pero se les imita en todo. En nuestras sociedades ocurre a la inversa ([1987] 2009, 310, subrayado mío).

Con esta alteración del argumento original, la imitación se dispara entonces en múltiples direcciones. En principio ya no estamos simplemente frente a la imitación que una clase realiza de la otra, sino de una sociedad en la que cada quién imita al resto. Por lo demás, esa imitación colectiva y descentrada se produce igualmente en búsqueda de singularidad, de modo que el binomio identidad/imitación permanece como un núcleo que resiste quizá incluso fortalecido- las críticas de Lipovetsky. Por otra parte, al apelar a un individuo desprovisto de relaciones sociales, el autor no puede explicar el cambio mejor que sus antecesores: las prendas de moda cambian porque hay una voluntad social de que así ocurra, y esa voluntad, a su vez, desea nuevas prendas en la medida en que estas están disponibles en el mercado. En mi opinión, el individualismo de Lipovetsky queda así encerrado en un laberinto sin salida en el que el autor tiene que apelar continuamente al hedonismo para explicar el consumo y al consumo para justificar el hedonismo.

Por otra parte, allende este apego lipovetskyano a la formación discursiva inaugurada por sus antecesores, me interesa destacar como particularidad de su enfoque la relación antes aludida entre moda y modernidad. Con Baudelaire como su principal antecedente, Lipovetsky sienta en efecto las bases de una periodización que será común entre los 
historiadores de la moda, ${ }^{7}$ a saber: la que hace de esta un fenómeno exclusivamente moderno en virtud de su vínculo a las sociedades industriales y la posibilidad que estas últimas conllevan de confeccionar prendas de forma masiva. Así pues, siguiendo tanto a Baudelaire como a Baudrillard, ${ }^{8}$ Lipovetsky afirma la pertenencia de la moda a un período con unas dinámicas de consumo muy específicas y hace depender el propio concepto de moda del fenómeno del consumo y la difusión masiva de objetos. Mediante esta argumentación, Lipovetsky refuerza la idea ya anteriormente examinada a la luz de los teóricos de la emulación según la cual el asunto central por explicar en torno a la moda es el de la naturaleza de sus mecanismos difusores. Si varios de los autores anteriormente comentados habían aceptado una especie de continuum entre las sociedades premodernas y las modernas y habían situado el auge de la moda en estas últimas, la novedad introducida por Lipovetsky consiste entonces en realizar una argumentación en pro de la tesis de que la moda comienza una vez que se dejan atrás las sociedades medievales y aparecen las sociedades modernas: la moda se convierte entonces en un asunto propiamente moderno y ya no en un problema de instintos. La moda tendría así unos comienzos geográfica y cronológicamente muy específicos, pero también un vínculo epistemológico con la aparición de las sociedades de mercado: solo en ellas, en efecto, el consumo orientado por el capricho individual se convierte en una posibilidad real. La moda y el problema de la difusión encuentran así en las tesis de Lipovetsky un tipo de relación que consolida su vínculo. En otras palabras, a través de la interpretación de Lipovetsky la moda termina de afianzarse como un problema de preferencias estéticas y de consumo. De este modo, la alianza entre modernidad, moda y consumo se erige como una suerte de lugar común en los estudios de la moda. Se trata, de nuevo, de una periodización que depende directamente de una concepción de la moda como un fenómeno caracterizado por su particular tipo de difusión.

\footnotetext{
${ }^{7}$ Véase a manera de ejemplo el trabajo del reputado historiador de la moda James Laver ([1982] 2008).

${ }^{8}$ Baudelaire, en efecto, había defendido ya en el siglo XIX una entrañable ligazón entre la moda y la modernidad, pues según el poeta la actitud moderna consiste precisamente en "extraer de la moda lo que ésta puede contener de poético en lo histórico, de obtener lo eterno de lo transitorio" (Baudelaire, [1862] 1995, 91) -respecto del enfoque baudelaireano del asunto del vestido véase la primera sección del capítulo 6-. Baudrillard, por su parte, también había señalado ya, aunque de una forma más perentoria, que "sólo hay moda en el marco de la modernidad" (Baudrillard, [1976] 1980, 103)
} 
Recapitulando, la moda aparece entonces en la tradición abierta por Veblen y Simmel -y continuada por diversas vías a través de los autores que les sucedieron-, como una problemática en la que la emulación de clase, la lucha por la distinción, la cuestión de la identidad y la asociación entre prenda y lenguaje constituyen una suerte de axiomas que aparecen como el resultado de operaciones teóricas que se articulan alrededor del problema de la difusión y el consumo. Por mi parte, quisiera como señalé más arriba trazar una genealogía que, por el contrario, ponga de manifiesto el modo en que esas nociones se relacionan con prácticas de poder específicas ligadas al cuerpo. Se trataría, por tanto, de estudiar la vestimenta a partir de sus efectos en los cuerpos, así como de distanciarnos de los enfoques que reducen la moda a un problema de consumo. Sin embargo, para ello es necesario, primeramente, mostrar la artimaña teórica que, dentro de las teorías de la imitación, hacen del cuerpo una superficie natural anterior a los vestidos. 


\section{Capítulo 2. El cuerpo desnudo}

Lejos de ser exhaustivo, el panorama que he querido dibujar en el capítulo anterior pretende ante todo cartografiar un problema así como señalar las principales matrices analíticas desde las cuales se ha abordado el mismo (muchas otras obras han de hecho versado sobre el tema del vestido y muchas de ellas serán comentadas acá en su debido momento). Por lo pronto, cabe señalar que si tal y como lo sugiere Foucault los fenómenos sociales no son enteramente divorciables de las coordenadas epistemológicas a partir de las cuáles se los comprende, la moda aparece a partir de las teorías descritas anteriormente como un asunto de consumo, cuyo principal rasgo es su peculiar modo de difusión. La historia de la moda, y por lo tanto la moda misma, aparece en los estudios especializados como un asunto de emulación y de clases, de identidad y lenguaje. También como un problema de consumo y de preferencias estéticas.

La pregunta que anima este y los capítulos siguientes es, por el contrario, qué pasa con la moda, con ese conjunto de prácticas, dispositivos y discursos que la conforman, si intentamos interpretarla como un ejercicio de poder dirigido especialmente al cuerpo antes que como un asunto de consumo. En otras palabras, quisiera partir acá de la convicción de que si bien la moda, tal y como lo ha creído la tradición, puede remitirnos en primera instancia al fenómeno del consumo, dicho fenómeno no es sino la manifestación más obvia de un problema anterior relacionado con el disciplinamiento de las apariencias y la clasificación social de los cuerpos y las conductas. El consumo, en tanto mecanismo difusor, constituye por lo tanto, en mi opinión, únicamente uno de los rasgos de una institución que en realidad despliega un amplio conjunto de dispositivos dirigidos a controlar el cuerpo mediante el atavío. La moda, entonces, se revela, tal y como intentaré mostrarlo en la segunda parte del presente escrito, como un espacio en el que tienen lugar prácticas disciplinantes y estrategias de control biopolítico, y no únicamente como una institución que nos desafíe a explicar los cambios, las preferencias, la propensión a la imitación o los lenguajes creados en torno al vestido. 
Esto no quiere decir que los problemas planteados por la tradición sean pseudoproblemas, o asuntos poco dignos de atención (de hecho retomaré algunos de ellos intentando reposicionarlos desde el punto de partida epistemológico aquí elegido), sino simplemente que a menudo suponen aquello que tendrían que explicar, sobre todo en lo tocante al cuerpo y la subjetividad. Puntualmente, a lo que me refiero es a que dichas teorías dan por sentado la existencia de unos cuerpos cuya identidad es supuestamente anterior a toda emulación o a toda producción de un lenguaje sígnico a través de las prendas, cuando se podría sospechar que son precisamente esas prácticas (aunque no solo ellas) las que proveen a los individuos de una identidad. En una palabra, los estudios sobre moda tienden a suponer una antropología filosófica esencialista que es precisamente la que me interesa desmontar acá a fin de mostrar cómo la moda funciona a la manera de mecanismo de poder vinculado a la producción de sujetos.

En tal sentido, cabe sostener que las teorías clásicas parten de constantes antropológicas que si bien muchas veces sugieren que en la moda hay involucrados mecanismos de dominación, las más de las veces explican esa dominación únicamente en términos de alienación consumista -es el enfoque, por ejemplo, de Naomi Klein ([2000] 2007) o de Heath y Potter ([2004] 2005), entre muchos otros-. Así, se coloca en el origen del problema de la moda unas prácticas que en realidad son efectos de tecnologías de poder específicas. Por ello, en adelante partiré del punto de vista epistemológico según el cual habría que rechazar cualquier explicación general o universal sobre la moda -ya sea psicológica, antropológica o biológica- no porque esas explicaciones estén condenadas a la falsedad, sino porque esa elección de método no permite comprender las operaciones de poder que tienen lugar alrededor de la vestimenta. En tal sentido, como lo he indicado ya en la introducción, en los capítulos siguientes procuraré desplegar una genealogía de la moda más que continuar alguna de las teorías anteriormente examinadas (aún cuando ciertamente la perspectiva que desplegaré acá puede ser leída complementariamente con la teoría del cuerpo propia de la sociología de la moda de Bourdieu).

Desde esta perspectiva, considero necesario analizar, en primera instancia, el rol del cuerpo dentro de las teorías del vestido anteriormente examinadas. De hecho, considero 
que dentro de los engranajes teóricos que ubican los problemas de la difusión y el consumo como asuntos centrales de la filosofía de la moda, el cuerpo desnudo aparece como un enclave central que dota de coherencia y unidad a un conjunto diverso de conceptos e ideas. La desnudez funciona, en tal sentido, no solo como garantía de un principio (en la medida en que, como lo mostraré más adelante, la moda, tal y como se la suele teorizar, necesita de un cuerpo en estado bruto para que el vestido aparezca como problema), sino que además se piensa como un terreno vacío, sígnicamente neutro, propenso a ser recubierto por unas prendas, ellas sí, capaces de significación. El cuerpo desnudo se erige así en las distintas teorías de la moda presentadas en el capítulo anterior como una superficie estable sobre la cual tienen lugares los cambios que deben ser explicados, como un núcleo anterior a las dinámicas culturales que merecen descifrarse, pero nunca como un problema en sí mismo. En otras palabras, las reflexiones clásicas en torno a la moda tienden a funcionar con una noción de cuerpo que hereda una serie de supuestos de la anatomía, la biología y el psicoanálisis y que deja varios núcleos filosóficamente problemáticos sin explorar.

Por lo tanto, mi intención en este capítulo es precisamente discutir críticamente el gesto teórico que hace de la desnudez una noción axial a la hora de enmarcar la moda como problemática filosófica. Para ello presentaré, en primera instancia, las coordenas epistémicas dentro de las cuales aparece la desnudez como una noción estratégica dentro de la filosofía de la moda. En segunda instancia me ocuparé de mostrar cómo la visión del cuerpo desnudo como una entidad natural en guerra forma parte de una red metafórica que excede el campo de los estudios del vestido y que goza de una amplia extensión cultural. Posteriormente destacaré algunas de las metáforas biológicas expresamente utilizadas por los filósofos de la moda. Por último, me dedicaré a mostrar las insuficiencias de la concepción filosófica de lo corporal propias de la filosofía de la moda para oponerla a una visión del cuerpo en la que este aparece como una superficie inestable que la vestimenta contribuye a gestionar.

Mi objetivo en este capítulo, por lo tanto, es mostrar que las teorías del vestido tienen en el cuerpo un presupuesto epistemológico central. En esa medida, partiré de la premisa de 
que repensar el cuerpo desnudo tal y como aparece en esas teorías equivale a abrir una puerta para plantearle a la moda una serie de preguntas filosóficas que históricamente se han dejado de lado.

\subsection{La desnudez como recurso retórico}

A partir de la premisa foucaultiana según la cual la labor crítica consiste, antes que en la resolución de un problema teórico, en el develamiento de las condiciones que han hecho posible dicho problema (Foucault, [2008] 2010, 38), la moda se revela como un campo problemático desde su misma génesis y el cuerpo desnudo como un importante enclave para las teorías que intentan explicarla. En La arqueología del saber ([1969] 2007) Foucault señala que los distintos aspectos de una formación discursiva - la referencia a un mismo objeto, la utilización de un mismo tipo de enunciación, la alusión a un mismo grupo de conceptos y la referencia a conjuntos de temas (Foucault, [1969] 2007, 5064)_- dependen de procesos y dinámicas históricas que los enmarcan, conforman y vinculan. Las formaciones discursivas requieren de una serie de criterios epistémicos que en los trabajos posteriores de Foucault aparecen vinculados, además, a relaciones sociales y políticas. En esta medida, para Foucault los discursos se producen en el interior de registros que se dan por sentados y que sin embargo son los que los dotan de veracidad y validez. Los discursos se construyen, en suma, a partir de dinámicas sociohistóricas que fijan horizontes de legibilidad. En este sentido, la apelación de toda matriz discursiva a un conjunto de recursos conceptuales y/o metafóricos, así como su validación (ora implícita, ora explícita) de ciertas prácticas en contraposición a otras pone, en el corazón mismo de la producción de discursos, el asunto del poder.

Partiendo de este enfoque considero que la recurrencia de las distintas filosofías de la moda a un mismo conjunto de redes conceptuales y metafóricas en las que la desnudez ocupa un lugar central es algo más que una casualidad epistemológica. De hecho, el análisis que realizaré de esas convergencias busca precisamente develar el núcleo que las hace posibles. La hipótesis que pretendo desplegar acá, por tanto, es que los discursos 
teóricos analizados en el capítulo anterior dependen del cuerpo desnudo -entendido como reducto natural anterior a lo social- en la medida en que dicha comprensión de la corporalidad valida una ontología de la moda que inscribe la problemática de la vestimenta en un registro bélico/biológico.

Para tales efectos parto de una perspectiva similar a la que defiende el filósofo italiano Giorgio Agamben en su obra Desnudez ([1999] 2011). En opinión de Agamben, la desnudez no es un dato biológico sino un concepto histórico que se ha vuelto legible dentro de un régimen discursivo específico. De este modo, según el filósofo, "la desnudez debería (...) remontarse arqueológicamente más allá de la oposición teológica desnudez/vestido, naturaleza/gracia, pero no para alcanzar un estado precedente a la escisión, sino para comprender y neutralizar el dispositivo que la produjo" (Agamben, [1999] 2011, 97). A diferencia de Agamben, sin embargo, considero vital no solo rastrear arqueológicamente la noción de desnudez (cuya genealogía, por lo demás, desbordaría ampliamente lo teológico) sino también analizar sus efectos, específicamente los que tienen lugar en el ámbito de la moda.

Desde este punto de vista, me interesa defender la idea de que las reflexiones a propósito de la moda descritas en el capítulo anterior se despliegan sobre un fondo de metáforas biológicas que dependen directamente de una determinada filosofía del cuerpo y de una conceptualización muy precisa de la desnudez. Considero que al pensar la desnudez como un hecho biológico, los filósofos de la moda ven en los fenómenos vestimentarios acontecimientos que poseen una continuidad con la naturaleza y que por lo tanto carecen de una raíz estritcamente social. A partir de un cuerpo biológico que se piensa en medio de una guerra por la sobrevivencia, el cuerpo vestido se inscribe igualmente en una especie de "guerra por la distinción", es decir, en un conjunto de luchas que según los filósofos de la moda libra el cuerpo vestido: guerras por el prestigio, por el lujo, por la originalidad o por el derecho de pertenencia a una clase o grupo determinado.

Desde mi perspectiva, la dialéctica de la emulación y la búsqueda de distinción y prestigio social fundada por Veblen y Simmel dependen de discursos biológicos que se 
refieren a los seres vivos como organismos o especies en competencia. De un modo complejo, los discursos sobre la moda superponen, en efecto, argumentos de orden biológico y sociológico en los que las batallas en búsqueda de la distinción social tienen su origen, de forma simultánea, en la naturaleza y la cultura. Así, el vestido es teorizado a menudo como una segunda piel que distingue el cuerpo natural (es decir, el cuerpo desnudo) del cuerpo artificial (es decir, el cuerpo socialmente intervenido o cubierto con vestidos).

El cuerpo desnudo, pensado como lo opuesto al cuerpo vestido, establece así un continuum entre sociedad y naturaleza, pero al mismo tiempo fija un límite entre ambas, funcionando como una especie de concepto bisagra. En esa medida, tal y como intentaré mostrar en las páginas siguientes, la desnudez, al quedar inscrita retóricamente hablando en un marco biológico/bélico, legitima una comprensión del cuerpo como superficie de intervención del poder.

\subsection{La extensión cultural de las metáforas biológicas y bélicas}

El hecho de que el cuerpo desnudo sea conceptualizado a partir de metáforas biológicas con contenido bélico no es algo fortuito. Las concepciones de lo social basadas en la naturaleza, de hecho, pueden remontarse inclusive hasta la Antigüedad. El historiador inglés G. E. R. Lloyd, por ejemplo, señala que ya "la ética y el pensamiento político de Aristóteles esta[ba]n profundamente influenciados, e incluso podría decirse, fundados, en su concepción de la naturaleza" (1968, 82; traducción propia). Sin embargo, la presencia de redes metafóricas basadas en la naturaleza cobra en la modernidad una relevancia enteramente distinta dada la alta legitimidad cultural que en dicha época poseen los discursos científicos. La filósofa estadounidense Carolyn Merchant (2006) ha mostrado cómo la ciencia moderna basa, en efecto, todo su desarrollo experimental en una retórica sobre la naturaleza que la concibe de forma pasiva -haciéndola coincidir con una feminidad estereotipada- para justificar, así, un tipo de intervención violenta sobre la misma. En relación con la retórica científica, Merchant indica cómo en el caso de ciertos 
teóricos de la ciencia como Francis Bacon "la elección de las palabras forma parte de un extenso proyecto para crear un nuevo método que pudiera permitir a la humanidad controlar y dominar el mundo natural" (Merchant, 2006, 518; traducción propia). Para Merchant, así, la revolución científica se basa en un particular modo de comprender la naturaleza que justifica su manipulación a la manera de una tortura. En otras palabras, las metáforas sobre la naturaleza no son imágenes aisladas evocadas con fines estrictamente retóricos, sino que constituyen un dispositivo propio de nuestra época, sobre todo a partir de su inserción dentro de discursos científicos.

El lingüista George Lakoff y el filósofo Mark Johnson señalan, por su parte, que las metáforas, lejos de ser meras construcciones lingüísticas inocentes son un recurso poderoso que organiza el mundo y la forma en que nos desenvolvemos en él. En opinión de los autores, "la esencia de una metáfora es entender y experimentar un tipo de cosa en términos de otra" (Lakoff y Johnson, [1980] 1986, 41), razón por la cual la apelación a metáforas no solo afecta nuestro sistema conceptual, sino que también incide en la manera en que comprendemos lo que hacemos y lo que sucede a nuestro alrededor. En este sentido, "lo que importa no es la verdad o falsedad de una metáfora, sino las percepciones e inferencias que se siguen de ellas, y las acciones que sanciona" (Lakoff y Johnson, [1980] 1986, 200). Las redes metafóricas, según estos autores, generan no solo un conjunto de sentidos, sino que además poseen una coherencia sistémica y una consistencia que se construye culturalmente. Esa coherencia, sin embargo, no siempre se crea del mismo modo. Algunas veces unas metáforas arrastran consigo nuevas metáforas; otras un solo concepto combina varias estructuraciones metafóricas. En ciertas ocasiones distintas estructuras metafóricas destacan diferentes aristas de un mismo concepto, mientras que en otras una misma estructura puede reunir diversas experiencias, asimilando así lo que de otro modo podría ser entendido de forma heterogénea (Lakoff y Johnson, [1980] 1986, 127-146). ${ }^{9}$ Lakoff y Johnson subrayan el hecho de que los distintos grados de articulación metafórica inciden directamente en el ámbito experiencial, de modo que "los cambios en nuestro sistema conceptual cambian lo que es

\footnotetext{
${ }^{9}$ María Luisa Femenías señala, en este mismo sentido, que ya para Aristóteles "la metáfora refleja (...) un aspecto de las cosas y, en consecuencia, lleva el conocimiento por vía del descubrimiento de los rasgos semejantes que hay en lo diferente" (Femenías, 2001, 72).
} 
real para nosotros y afectan la forma en que percibimos el mundo y actuamos sobre la base de esas percepciones" (Lakoff y Johnson, [1980] 1986, 187). De este modo, en la construcción de metáforas estarían implicadas, según estos autores, cuestiones no únicamente de orden lingüístico, sino también epistemológico y político. De ahí que señalen que la manutención del poder depende directamente del prestigio social que se le asigna a ciertas metáforas por sobre otras (Lakoff y Johnson, [1980] 1986, 199).

Según Lakoff y Johnson, la guerra, lejos de ser una imagen entre otras, es una de las metáfora que goza de mayor difusión cultural. De hecho, lo bélico sirve para dichos autores como modelo metafórico para un espectro muy amplio de experiencias:

[...] sea en un marco científico, académico o legal, aspiremos al ideal del argumento racional o estemos simplemente tratando de salirnos con la nuestra en nuestra propia casa por medio de regateos, la forma en que concebimos, llevamos a cabo y describimos nuestras discusiones, se basa en la metáfora una discusión es una guerra ([1980] 1986, 105).

Así, el acto de discutir es conceptualizado, y por lo tanto experimentado, a partir de una red conceptual que invita a elaborar estrategias, a urdir planes y a lanzar amenazas, así como a contraatacar, retirarse o rendirse.

Sin embargo, como lo señalaba antes, el poder de la metáfora bélica excede por mucho el campo estrictamente retórico. La difusión de la metáfora bélica en la modernidad ha tenido lugar en buena medida, como ya he indicado, gracias a su inserción en redes metafóricas provenientes de la ciencia que gozan de una gran influencia social. La humanidad entendida como especie biológica en guerra, de hecho, es una metáfora que incide no solo en distintos espectros de lo cotidiano, sino también el modo en que se construyen los discursos científicos y, por lo tanto, en la manera en que se piensan los cuerpos y su interacción.

Un buen ejemplo de cómo lo bélico/biológico aparece como modelo discursivo en la historia de los saberes occidentales puede encontrarse en los análisis que Foucault realiza en sus cursos de mediados de los años setenta en el Collège de France, específicamente 
en Los anormales ([1999] 2002) y Defender la sociedad ([1997] 2010). En ellos, Foucault intenta dar cuenta del modo en que la guerra se estableció como principio de inteligibilidad de la historia y de la sociedad misma en la Europa de los siglos XVI y XVII. La guerra, ya no en tanto estado natural como en Hobbes, sino en tanto conjunto de episodios históricos concretos que habrían dado su forma a las sociedades europeas modernas, se convierte, no solo para los historiadores franceses del siglo XVI $-\mathrm{v}$. gr. Hotman- sino también para los historiadores ingleses del siglo XVII -Coke y Shelden, por ejemplo-, en el fundamento mismo de la sociedad civil. Como lente de interpretación histórica, la guerra posee además, según Foucault, un doble origen biológico/social que la hará desplegarse de manera bifronte, es decir, tanto a nivel de las razas como de las clases:

[...] lo importante [para los historiadores de la época en cuestión] es que el principio del análisis histórico se busque en la dualidad y la guerra de razas. A partir de ahí (...) van a desarrollarse en el siglo XIX dos tipos de desciframiento de la historia: uno se expresará en la lucha de clases; el otro en el enfrentamiento biológico (Foucault, [1997] 2010, 244).

A partir de la lectura cruzada de Los anormales y Defender la sociedad se podría concluir que el origen del traslape entre biología y sociología (mucho anterior, por lo demás, a las formulaciones de la sociobiología del siglo XX) depende tanto de la instauración de los discursos normalizantes y patologizadores del siglo XIX (psiquiatría, pericias médicolegales, etc.) como del desarrollo de un modo de interpretación histórica que ve en la guerra y sus metáforas el principio de inteligibilidad de lo social. Foucault muestra, además, que al conceptualizarse lo histórico como un campo de fuerzas motorizado por la guerra en el marco de sociedades normalizantes, el resultado es una sociedad belicista y altamente hostil hacia la anormalidad. De este modo, a partir de una hibridación de saberes provenientes de la biología y la historia, las sociedades europeas de los siglos XVII, XVIII y XIX plantean la impronta de defender la sociedad de los anormales en un movimiento teórico que impactará un espectro amplio de discursos. Así, el concepto de anormalidad se consolida en la Europa decimonónica a partir de una heterogénea trama discursiva que abarca entre otros saberes la medicina -cuyo anormal predilecto es el onanista-, el derecho -cuya comprensión de la anormalidad se condensa alrededor de la 
figura del individuo peligroso- y la biología - cuyo anormal, el mounstruo humano, será objeto de reflexión en el marco de la embriología- (Foucault, [1999] 2002, 300-301). La impronta de estos saberes será entonces crear mecanismos de defensa frente a una sociedad acosada por sus bioenemigos internos: los anormales. Al mismo tiempo, la lucha queda fijada a partir de estas reconfiguraciones epistemológicas como un lente de interpretación histórico y social.

Otro agudo análisis que desmantela la articulación entre metáforas bélicas y biológicas en las sociedades modernas, esta vez en los ámbitos primatológico y biomédico, es el que realiza la feminista estadounidense Donna Haraway en su conocido libro Ciencia, cyborgs y mujeres ([1991] 1995). Su obra, en pugna abierta con la sociobiología, ve en la biología un saber que, lejos de ser ideológicamente neutral, se ocupa de construir "teorías sobre el cuerpo y la comunidad como máquinas y como mercados capitalistas patriarcales" ([1991] 1996, 72). Siguiendo parcialmente a Foucault, Haraway denuncia el modo en que los sociobiólogos, al conceptualizar la sociedad como un organismo en el que compiten fuerzas, legitiman un orden político en el que la lucha se convierte en un dato antropológico que no se somete a problematización filosófica alguna. La sociobiología, de este modo, encubre una serie de convicciones políticas (xenófobas, patriarcales, etc.) presentándolas como datos científicos que describen neutralmente la naturaleza. Del mismo modo, la autora llama la atención sobre la incidencia que la primatología ha tenido en la comprensión social de la normalidad y la salubridad, y da cuenta del modo en que los estudios sobre primates utilizan la metáfora del cazador como motor evolutivo y por lo tanto como factor explicativo de la historia. Así, a partir de la bifurcación de caminos entre la primatología, las nuevas tecnologías y los nuevos órdenes mundiales imperialistas, surgen, según Haraway, una serie de constructos metafóricos a partir de los cuales se entenderá el comportamiento animal y, por extensión, el comportamiento humano, como los comportamientos de especies en guerra. Por otra parte, la autora analiza la manera en que el discurso biomédico informa las experiencias de la enfermedad y la muerte a través de complejas redes metafóricas que combinan categorías farmacéuticas, académicas, sanitarias, industriales y económicas en las que la guerra deviene un recurso explicativo axial. En este sentido, Haraway identifica una serie 
de elementos conceptuales y metafóricos a partir de los cuales se investiga y se discurre sobre el sida, y muestra cómo en ellos abundan las imágenes bélicas. El tropo de la invasión y la defensa en el discurso inmunológico determinará no únicamente el norte de las investigaciones científicas, sino el modo en que se piensa la enfermedad como un ataque y en que se percibe a los cuerpos enfermos como organismos invadidos. De ahí que Haraway insista en una comparación sumamente sugerente: la de los discursos biomédicos y el imaginario de la Guerra de las Galaxias. El modo de conceptualizar el cuerpo humano, desde la primatología y la sociobiología, y hasta la biología y la medicina, dependería directamente, según la autora, de una red de metáforas condensadas en la imagen de una Guerra de las Galaxias: a saber, una especie de imaginario social sobre la invasión biológico/bélica que se aplica no solo en la ciencia sino también al ámbito del entretenimiento y la política ([1991] 1995, 314).

Partiendo tanto de los análisis de Haraway y de Foucault como de los de Lakoff y Johnson cabe concluir que la guerra como grilla de inteligibilidad con una raíz biológicosocial permea las estructuras narrativas de diversos discursos contemporáneos, y que en la consolidación y puesta en circulación de este tipo de metáforas hay en juego un asunto de hegemonía cultural. En este sentido, como lo indica Femenías, la utilización del recurso metafórico "pone de manifiesto lo que a juicio de quienes lo inventan o la utilizan es admitido como primordial" y establece, a consecuencia, "un cierto modo, por así decir, de 'ver' el mundo" (2001a, 72).

Desde este punto de vista, la moda sería uno más de esos discursos que se vale de metáforas bélico/biológicas. La participación de la filosofía de la moda de esa episteme bélico/biológica es de suyo importante para comprender al papel que la desnudez jugará en los estudios sobre moda: se trata de un concepto que pone a funcionar la idea de naturaleza al interior de los discursos sobre moda. Asmismo, el tema de la lucha permitirá a los teóricos del vestido centrar la atención en la moda cual si se tratara de una extensión o continuación de las luchas por la sobrevivencia. Las metáforas bélicas se plasman en la filosofía de la moda, pues, propiciando la comprensión de los cuerpos vestidos como cuerpos que, en continuidad con las luchas evolutivas por la 
sobrevivencia, se encuentran en una lucha desenfrenada por la distinción, el prestigio, el lujo y el glamour. Dentro de ese contexto, tanto el cuerpo desnudo -en tanto entidad biológica que lucha por la sobrevivencia- como el cuerpo vestido -en tanto entidad cultural que lucha por la distinción- aparecen conceptualizados como cuerpos en guerra. La continuidad entre esas dos clases de lucha es justamente la que permite entender porqué la moda se conceptualiza usualmente partiendo de una comprensión biologicista del cuerpo cuando constituye, a todas luces, una expresión cultural.

\subsection{Las metáforas biológicas y la moda: especies, luchas y vestidos}

El encuentro entre la biología y la guerra en el ámbito de la filosofía de la moda no se da sin que medien una serie de operaciones retóricas específicas. Esas operaciones se plasman en un conjunto de metáforas que abundan en la bibliografía especializada y que conectan de un modo no siempre reflexionado lo biológico (cuerpo desnudo) con lo cultural (cuerpo vestido). A partir de estas metáforas, en efecto, lo que parecieran simples comparaciones con afanes explicativos fijan sentidos alrededor del cuerpo y establecen unas ciertas coordenadas epistémicas desde las cuales se analizan las relaciones entre la sociedad, la naturaleza y la vestimenta. En otras palabras, se trata de metáforas que traen consigo consecuencias ontológicas, en la medida en que configuran grillas de inteligibilidad a partir de las cuales se piensa culturalmente la relación entre el vestido y el cuerpo -acerca del carácter ontológico de la metáfora véase Bach, Femenías y Roulet $(1994,187)-$

Una de esas metáforas que opera en el interior de la filosofía de la moda es la que analoga la moda con una lucha evolutiva por la distinción. Tal y como lo como señalé en el primer capítulo, desde Simmel y Veblen hasta el presente, la moda ha tendido a ser conceptualizada como una batalla entre individuos cuyo fin es diferenciarse del resto. Ese afán de diferenciación se concibe como si fuese una lucha no porque medie ningún tipo de fuerza física ni combate corporal alguno, sino porque ese giro retórico permite ubicar la moda dentro de una cadena de acontecimientos históricos leídos en clave biologicista. 
Veblen, por ejemplo, considera que el consumo ostenso, del cual la moda es una de las manifestaciones más importantes, substituye la vieja distinción entre quienes son capaces de distinguirse mediante hazañas y aquellos que son incapaces de hacerlo (Veblen, [1899] 2005, 16). El consumo de vestidos de lujo constituye, de hecho, una forma más elevada de distinguirse dentro de la escala evolutiva de la especie. En otras palabras, Veblen explica la difusión de las modas a partir de su inscripción dentro de un continuum evolutivo en el cual el vestido aparece como una institución a un tiempo natural (en la medida en que se asemeja a otros procesos evolutivos) y social (en la medida en que involucra prácticas eminentemente culturales como el consumo y el uso de dinero). A partir de la metáfora de la moda como lucha de la, el tema del consumo y de las preferencias estéticas aparece vinculado sin ningún tipo de mediación a procesos evolutivos tal y como estos se conciben desde la biología darwinista. Veblen considera, así, que la búsqueda de distinción a través del vestido se asemeja a otros arcaicos medios de distinción que en algún momento se habrían dado en torno a la proeza y la hazaña (Veblen, [1899] 2005, 36). En otras palabras, el prestigio que el estar a la moda trae consigo viene a asemejarse al reconocimiento que otrora se obtenía a través de gestas que tenían lugar en un entorno natural amenazante. Flügel, por su parte, siguiendo a Spencer (significativamente uno de los instauradores del darwinismo social en Inglaterra) señala de manera similar que los individuos llevan al ámbito vestimentario un afán de distinción que en épocas pretéritas se habría manifestado a través de la obtención de trofeos de casa (Flügel, [1930] 1964, 28-30). Así, este último autor establece un ligamen metafórico entre la distinción obtenida por medio de gestas físicas y la distinción cosechada a través de la vestimenta de lujo.

Mediante esta metáfora de la moda como continuación de una lucha biológica, los autores mencionados anclan una cierta dinámica sociocultural en la naturaleza e inscriben metafísicamente el consumo de modas en un marco bélico -véanse en este sentido los análisis de Córdoba $(2010,53)$ y Simón (2010, 90-91)-. Dicha metáfora, en efecto, hace del cuerpo una substancia compelida por la naturaleza a una eterna batalla en busca de distinción que, si bien cambia sus medios (ayer la caza, hoy la moda), permanece a lo largo de la historia a la manera de una esencia. La lucha, de este modo, se presenta como 
un rasgo consustancial a lo humano y el cuerpo como una entidad fundamentalmente natural que, guiada por sus impulsos, permanece idéntica a sí misma a pesar de los cambios en el entorno social.

Esta metáfora reaparece -aunque reformulada y adaptada- en los estudios sobre moda a través de las teorías que ven en esta una expresión de la lucha de clases. Así como en la metáfora anterior la moda aparecía como una guerra natural, en esta segunda versión de la metáfora bélica la moda aparece como resultado de una confrontación de índole económica. Sin ánimo de negar ingenuamente el hecho de que efectivamente existen una serie de desigualdades económicas que estructuran las sociedades en clases, considero que la visión de la moda como una guerra entre clases da un salto metafórico en el que, de nuevo, la noción de lucha arrastra consigo una serie de ideologemas biologicistas con consecuencias ontológicas. En efecto, las teorías que afirman que la moda surge de la lucha de clases tienden a establecer una continuidad entre este tipo de lucha y las propiamente biológicas. König, por ejemplo, señala que los vestidos de lujo utilizadas por las clases altas substituyen los antiguos trofeos conseguidos en las guerras ([1958] 1968, 75). Para dicho autor, en efecto, las luchas entre las clases encuentran en cierta tendencia primitiva a la rivalidad y la competencia su origen antropológico. König cree con Veblen, de este modo, que el consumo es siempre consumo suntuario y que, en esta medida, el fenómeno de la moda y de las pugnas de clase que la originan tienen su génesis en la naturaleza humana (König [1958] 1968, 91-98). Así, la lucha de clases es explicada en términos antropológicos que omiten dar cuenta de la raigambre estrictamente sociohistórica de las desigualdades económicas. Dentro de esta perspectiva, las clases son interpretadas en continuidad con diferencias evolutivas sin que medie ningún tipo de justificación para dicho salto teórico. En otras palabras, la categoría de clase queda emparentada metafóricamente con vetustas ditinciones jerárquicas, quedando así el uso suntuario de prendas remitido al ámbito biológico.

En suma, si bien la idea de una pugna social en la que la prenda aparece como emblema de clase puede, sin duda, corresponderse con una serie de episodios históricos, su inscripción en un registro bélico implica un modo de evocar los conflictos sociales que 
arrastra consigo prejuicios biologicistas y cierto esencialismo antropológico. Por otro lado, dicho enfoque no permite reparar en el papel activo que la moda juega en la conformación de los cuerpos y de las subjetividades de clase. En otras palabras, al fijar metafóricamente hablando una relación de causa y efecto entre las luchas evolutivas por el prestigio de un lado, y la moda del otro, se invisibiliza el hecho de que esta última constituye, antes bien, uno de los dispositivos mediante los cuales las sociedades producen las clases - cuestión que ciertamente advierte Bourdieu, al señalar el hecho de que las clases, lejos de ser fijas, involucran procesos de descomposición y recomposición por efecto de las distintas trayectorias vitales de los individuos (Bourdieu, [1979] 2012, 124-128)-. La subsunción de la moda dentro de la lucha de clases impide a pensadores como König, pues, pensar el papel activo que la moda juega a la hora de crear identificaciones de clase (volveré sobre este papel activo de la moda en tanto instancia de subjetivación más adelante en este mismo capítulo). En ese sentido, cabe dudar de la pertinencia de una metáfora que a todas luces recoge todo el peso semántico de la metáfora biológica anteriormente examinada.

Un segundo núcleo metafórico, aunque relacionado con la analogía de la moda como lucha, remite la subjetividad de los usuarios de moda a una teoría de los instintos: el usuario de modas aparece, así, como si fuese un individuo dominado por una particular forma de instinto. Dentro de esta segunda metáfora el afán de estar a la moda se explica entonces como una peculiar forma de instinto natural. Veblen, por ejemplo, se refiere a un "instinto de trabajo eficaz" [instinct of workmanship] cuando quiere explicar el origen de la difusión de las modas (véase apartado 1.1.). Dicho instinto, el cual se encuentra ligado, como lo señalé en el capítulo anterior, a una tendencia natural del ser humano a ahorrar energía y recursos, constituye una característica distintiva que en supuestos estadios arcaicos de la cultura habría suscitado un deseo de emulación (Veblen, ([1899] 2005, 23.24). La moda, por otra parte, aparece como resultado de una etapa evolutiva superior en la que dicho instinto no resulta suficiente para distinguirse. En dicha etapa aparece la clase ociosa, conformada justamente por aquellos que se distinguen del resto, entre otras cosas, debido a su capacidad de adquirir vestidos suntuosos. El gusto por la moda constituye, por ende, una práctica cultural que encuentra su origen en la dimensión 
biológica del ser humano, aunque para Veblen la moda sea al mismo tiempo una práctica instituida culturalmente. La distinción a través de la moda se asemeja entonces a la necesidad instintiva del ser humano de distinguirse por medio del trabajo eficaz. En la base de la moda Veblen encuentra, por tanto, una suerte de matriz antropológica que funciona con base en la biología y que compele a los individuos a querer destacar unos de otros.

Simmel, por su parte, también habla de la tendencia a querer estar a la moda como una suerte de instinto (véase al respecto el apartado 1.1). En su opinión, en efecto, la moda se difunde por intermedio de un "instinto imitativo" (Simmel, [1905] 2008, 72). La metáfora simmeleana de la emulación como una especie de instinto refiere de nuevo la vestimenta y la decoración a un constructo biologicista que permanece a lo largo de las épocas. Mediante este procedimiento teórico Simmel apela a una cierta esencia antropológica sin que medie discusión teórica alguna y justifica un cierto ordenamiento jerárquico en el que unos individuos siempre se encuentran a la vanguardia mientras que otros les emulan. Foucault señala que la noción de instinto acarreó una serie de consecuencias a partir de su uso estratégico dentro de las ciencias del comportamiento, dado que permitió remitir conductas y relaciones jerárquicas a la naturaleza. A partir de su aparición en los discursos criminológicos y psiquiátricos "el instinto será, [según Foucault], el gran vector del problema de la anomalía" ([1999] 2002, 128)-. En el campo de la moda, la atribución de comportamientos instintivos a los individuos seguirá un camino similar: la emulación aparece allí como si se tratase de un impulso connatural al ser humano y los problemas de la difusión de las tendencias vestimentarias y de las jerarquías que las modas generan, de nuevo, acabarán ligados de forma confusa a un cuerpo natural al mismo tiempo que social.

Un tercer núcleo metafórico proveniente de los estudios sobre el vestido establece una relación entre el cuerpo biológicamente considerado y la vestimenta como instancia de superación de cierto arcaísmo: el vestido se plantea, en tal sentido, como un recurso civilizatorio. En este sentido, la moda aparece de nuevo como resultado de un instinto pero al mismo tiempo como una instancia de trascendencia de la animalidad-recuérdese 
la tesis kantiana referida en la introducción-. En efecto, según una opinión compartida por los filósofos de la moda (Flügel, König y Squicciarino, entre otros) el único ser que se viste es el ser humano. Balzac, por ejemplo, afirma que "quien dice hombre (sic), en la civilización, dice hombre vestido; el hombre que sale desnudo de las manos de la Naturaleza [agrega el autor] está inacabado para el orden de las cosas en el que vivimos; al sastre corresponde completarlo" ([1830] 1998, 135). Para el teórico de la moda francés Paul Yonnet, por ejemplo, así como el lenguaje y las herramientas ponen a la humanidad en un peldaño evolutivo superior al resto de animales, el vestido separa al ser humano de un estadio anterior que lo aproxima a la animalidad:

[...] llevar vestidos informa [entonces] sobre el hecho de que quien los lleva pertenece al género humano (...). La vestimenta autoriza la comunicación en el seno del grupo y a menudo solo a esto se limita el concepto de hombre en numerosas sociedades" (Yonnet, [1985] 2005, 233).

La especie, así, no solo enfrenta grupos humanos que buscan distinguirse unos de otros, sino que también busca trascender una naturaleza imaginada como intancia opuesta a lo social. En el marco del binomio colonial civilización/salvajismo las prendas se convierten además en una señal de progreso evolutivo. Según Veblen, por ejemplo, "la necesidad del vestido es una necesidad eminentemente espiritual o superior" (Veblen, [1899] 2005, 174). Lipovetsky, por su parte, indica que la moda aparece una vez que el ser humano ha superado el salvajismo. Así, según este último autor, la moda es propia de los seres más evolucionados (Lipovetsky, [1987] 2009, 27). La metáfora de la moda como sinónimo de civilización produce otra problemática metáfora: la de aquellos que no se entregan a la moda como individuos salvajes. La moda constituye en tal sentido un auténtico elemento clasificador de los cuerpos: por un lado estarían los cuerpos vestidos y civilizados y, por otro, los cuerpos desnudos de los primitivos -véase al respecto Retana (2009)-. Así, la moda aparece como un recurso civilizatorio en el sentido de que permite rebasar cierto estado de naturaleza. En este contexto, la moda se considera también un elemento que permite atacar las limitaciones de la especie. Según apunta la teórica de la comunicación Sandra Valdettaro, la apelación constante de la publicidad a la tecnología como mecanismo para superar las imperfecciones del cuerpo, "muestra que la metáfora de la 
guerra presume un 'combate' para conquistar la belleza y la salud, que se modaliza (...) mediante un léxico militar"; de esta manera, la moda forma parte de una "guerra (...) contra la flacidez, la acumulación de grasas, las arrugas" (Valdettaro, 2010, 53). Lo corporal, aparece así, una vez más, como una instancia biológica susceptible de unas cuantas variaciones accidentales en su aspecto, pero no obstante con un núcleo substancial que permanece pese a los cambios.

Las filosofías de la moda recurren, por último, a una serie de metáfora biomédicas para explicar los mecanismos difusores propios de la moda. Cuando no se utiliza la metáfora geométrica de la imitación piramidal, se suele recurrir, en efecto, a imégenes medicalizantes como la del virus, el contagio o el frenesí. Simmel, una vez más, aparece como uno de los primeros enunciadores de esta metáfora al hablar del usuario de modas como un "frenético" acosado por cierto "nerviosismo" (Simmel, [1905] 2008, 82-83). Para Simmel, de hecho, el usuario de moda es presa de un afán desmedido de consumo y de una cierta "manía por la moda" ( [1905] 2008, 83). Notoriamente, la elección de palabras de parte de Simmel remite a un registro médico que se hará más patente en elaboraciones de autores posteriores. Ana Martínez Barreiro, por ejemplo, afirma que "en las sociedades postmodernas, las modas se propagan como el sida, las epidemias y los virus informaticos" $(2006,202)$. Dentro de este enfoque, la metáfora medicalizante del virus funciona como elemento explicativo de una dinámica social. El cuerpo vestido es susceptible de contagio a la manera en que ocurre con el cuerpo desnudo. Así, el vestido, pese a su raigambre sociocultural, se inscribe dentro de un lenguaje biomédico que remite la moda y el cuerpo a la naturaleza. Las preferencias estéticas y los canales difusores de la moda quedan determinados por cierto mecanismo febril que expande las tendencias a la manera en que la naturaleza expande las enfermedades. No solo en la literatura especializada sino también en las revistas de moda se recurre de forma continua, en efecto, a nociones biomédicas o al tropo de la moda como un fenómeno de contagio. Así, la metáfora de la moda como fiebre o como entidad viral fija de nuevo una relación entre el cuerpo, la vestimenta y la naturaleza sin que esa relación sea objeto de una reflexión explícita. 
Recapitulando, considero entonces que el hecho de que el conjunto de estas metáforas sean solidarias entre sí tiene que ver, como indicaba antes, con que todas ellas se inscriben en redes epistémicas más amplias que se utilizan contemporáneamente para hablar sobre el cuerpo, la naturaleza, la cultura y la sociedad. De hecho, como lo señalé supra, las metáforas biológico/médicas influyen desde hace mucho tiempo en la ética y la política. Mi pretensión, sin embargo, no es condenar el hecho de que exista dicha influencia -toda vez que como lo señalan Bach, Femenías y Roulet "la cualidad metafórica del lenguaje es ineludible" $(1994,192)$ - sino mostrar cuáles son sus efectos específicos en el ámbito de la moda. Lo que me interesa en el caso de estas metáforas que refieren la moda a imágenes relacionadas con guerras, especies y etapas evolutivas es, pues, el efecto que tienen en la propia concepción cultural que tenemos de dicha institución (una concepción que da por sentada una serie de creencias sobre el cuerpo, la naturaleza y los alcances de la vestimenta en tanto mecanismo de control). En ese sentido, considero que las consecuencias de esos constructos que evocan batallas y evoluciones son fundamentales, pues como Lakoff y Johnson señalan, las metáforas prescriben y sancionan acciones, justifican inferencias y establecen fines. Todas esas metáforas, no obstante, confluyen en su concepción del cuerpo desnudo, razón por la cual es menester, en el contexto de una genealogía de la moda, analizar el estatuto y la función epistemológica de la desnudez en el contexto de las teorías sobre el vestido. Precisamente a esa tarea me dedicaré en los apartados siguientes.

\subsection{El imposible cuerpo desnudo: las críticas a la visión psicoanalítica y anatomobiológica del cuerpo}

La concepción del cuerpo como entidad natural es tan antigua como canónica, no solo en la historia de la filosofía sino también en la ciencia misma. La inscripción del cuerpo dentro de un registro anatomobiológico delimita sus contornos y lo dota de una sintaxis que se supone inmanente a su materialidad. La vieja y recurrente imagen utilizada desde Platón hasta Descartes del alma como piloto del cuerpo imagina también la corporalidad como algo dado. Si bien la historia muestra que la corporalidad ha sido continuamente 
intervenida a lo largo de los siglos (a través de medicinas, cirugías y alimentos pero también de rutinas de ejercicios, productos cosméticos y vestidos), aún se considera que hay un cuerpo en estado bruto cuya constitución viene dada por la naturaleza.

Es esta última visión del cuerpo la que, por otra parte, domina en los estudios sobre moda de la mano de las metáforas antes descritas. El hecho de que el ser humano venga al mundo desprovisto de ropajes se presenta como un dato que respalda dicha constitución natural -véase al respecto, por ejemplo, Squicciarino ([1986] 1998, 54-80)-. Pero simultáneamente, el cuerpo es concebido, en tanto organismo, como una materialidad que exige una cierta administración social, por lo que requiere, entre otras cosas, ser recubierto con vestidos. El cuerpo, imaginado como un organismo en guerra por la sobrevivencia, se concibe entonces como una superficie virgen que reclama ser intervenida en aras de superar las dificultades que comporta el entorno natural, y es en esa medida que la moda (así como la medicina, la tecnología y otros dispositivos culturales más) encuentra la legitimidad para manipular e informar la corporalidad.

Pero, ¿de qué manera se ha justificado epistemológicamente hablando en la filosofía de la moda la aseveración de que el cuerpo es una substancia natural? El discurso anatomobiológico y el psicoanálisis constituyen dos hitos en lo referido a la legitimación de tal premisa epistemológica. En efecto, las diferentes teorías de la moda suelen encontrar en ellos su principal soporte epistemológico. Dichos discursos aseveran que el cuerpo posee una gramática que le es consustancial, por fuera de la cual lo que aparece es la anomalía patológica (volveré sobre este punto en el capítulo siguiente). Sin embargo, debido precisamente a su vocación patologizadora, esos saberes y las teorías del cuerpo que los mismos suscriben han suscitado múltiples críticas.

Algunas de ellas, como las realizadas por Foucault, apuntan a cuestionar la legitimidad de las visiones del cuerpo propias de la medicina, la sexología, los discursos psiquiátricos y los saberes criminológicos, mientras que otras, como las de los críticos franceses Deleuze y Guattary y las de la filósofa y psicoanalista belga Luce Irigaray, tienen como objetivo el cuestionamiento de la sintaxis corporal planteada por otros discursos que, como el 
psicoanálisis, peretenden conferir al cuerpo una sintaxis única desde contextos teóricos no estrictamente biologicistas.

La crítica foucaultiana a la idea de un cuerpo natural cuestiona, entre otras cosas, las pretensiones de verdad y los efectos de poder que los discursos científicos han tenido sobre el cuerpo. Extrapolando una tesis que ya había planteado en relación con la psiquiatría en su Historia de la locura (Foucault, [1964a] 2010 y [1964b] 2010)-según la cual la celebérrima aparición del internamiento psiquiátrico en sustitución del encierro no era ni un progreso ni un retraso sino una forma específica de abordar la locura en términos de un saber que la recortaba y definía-, Foucault encara estos discursos a partir de la tesis de que su historia no es la de una evolución creciente, ni tampoco la de un retroceso fatal, sino la historia del modo en que cada uno de ellos discurren sobre experiencias específicas (v. gr. el crimen, la enfermedad, etc.). En El nacimiento de la clínica (Foucault, [1963] 2008), por ejemplo, el filósofo analiza desde esta perspectiva los distintos modos en que el siglo XIX comprendió la enfermedad y su relación con el cuerpo, así como los avatares epistemológicos que, a partir de la constitución de la clínica como espacio de observación privilegiado, generan en un determinado momento una exigencia a la mirada médica: que diga la verdad sobre los cuerpos enfermos. El cuerpo observado por el médico es percibido, según Foucault, de distintos modos y con lógicas epistémicas variadas. A partir de una cierta reestructuración metafísica de la enfermedad que identifica lo visible con lo enunciable, la anatomía pasa a tener una importancia fundamental para la medicina moderna y el cuerpo se convierte, de hecho, en el escenario en el cual se desplegarán la enfermedad y la muerte. La tesis foucaultiana resulta pertinente para efectos de la presente investigación en tanto afirma que a partir del examen de los discursos médicos es posible reparar en las mútliples sintaxis que el cuerpo enfermo resiste.

En opinión de Foucault, también los discursos criminológico/penales reflexionan en torno al cuerpo en términos anatomobiológicos, imponiéndole una determinada gramática. Foucault analiza la prisión justamente como una compleja maquinaria encaminada a producir "cuerpos dóciles", es decir, cuerpos que devienen "objeto y blanco del poder" 
(Foucault, [1975] 2008, 158). Como lo señala acertadamente Judith Butler, para Foucault "entre los presos, (...) la táctica no ha sido reprimir sus deseo, sino obligar a sus cuerpos a significar la ley" (Butler, [1990] 2007, 264). De ahí que la microfísica del poder carcelaria sea caracterizada por Foucault como "celular": se trataría de un poder que se inscribe en los cuerpos y que por lo tanto les confiere una distribución material (Foucault, [2003] 2008, 31-32). La anatomía del preso, según los saberes criminológicos es, de hecho, una anatomía biológicamente desviada.

Otro tanto ocurre con la sexualidad. En torno a ella una serie de dispositivos (sexológicos, higiénicos, etc.) prescriben una cierta utilización del cuerpo. Contrariamente a lo enfatizado por Freud (en cuya teoría del deseo el peso lo tienen las prohibiciones) Foucault señala que los regímenes de normalización de la sexualidad prescriben zonas erógenas y fijan comportamientos (Foucault, [1976] 2005, 58). De este modo, tampoco el cuerpo sexuado está desprovisto de una organización específica, y su constitución y funcionamiento no vendría dado por la naturaleza ni por ningún régimen reproductivo independiente de los saberes que discurren en torno a él.

Los críticos franceses Deleuze y Guattari, así como la psicoanalista Luce Irigaray, por su parte, señalan una serie de limitaciones a la concepción psicoanalítica del cuerpo y analizan las consecuencias que se siguen de dicha concepción. Irigaray pone el acento de su crítica en el modo en que Freud lee la diferencia sexual bajo un sesgo masculinista que ve en el cuerpo femenino una derivación del cuerpo del varón. Las mujeres, según Irigaray, se definen dentro del universo freudiano por su carencialidad y su constitución orgánica es minimizada unilateralmente a sus funciones reproductivas. Mediante un retruécano argumentativo, Freud, según Irigaray, fija el falo como referente estructural del resto del cuerpo, de modo que la diferencia sexual se articula en torno a la tenencia o la carencia fálica (Irigaray, [1974] 1978, 25). Así, la autora muestra que el psicoanálisis no tiene en la anatomía freudiana una infortunada consecuencia de algunos prejuicios patriarcales de su fundador, sino el propio fundamento de una teoría del deseo que es masculina partiendo ya desde su propia comprensión de lo anatómico. En otras palabras, Irigaray denuncia cómo el binarismo sexual freudiano constituye un principio de 
inteligibilidad pese a que dicho binarismo contiene una serie de fisuras analíticas (volveré sobre la concepción freudiana del cuerpo sexuado en el capítulo séptimo). Deleuze y Guattari se refieren, dentro de una línea crítica afín, al sujeto como una máquina sin órganos, y critican la tentativa freudiana de poner orden en ese "mundo de producción salvaje y de deseo explosivo" propio del inconsciente (Deleuze y Guattari, [1972] 1985, 60). En opinión de estos autores la búsqueda freudiana de una estructuración del cuerpo obedece así, en última instancia, a la necesidad de fijar un orden a la máquina deseante.

A partir de las argumentaciones de los autores y autoras mencionados -aunque también de algunos aportes específicamente históricos que, como los del teórico alemán Norbert Elias ([1977] 2012) o del francés George Vigarello ([2001] 2005), muestran los órdenes somáticos en su más plena historicidad- considero posible aseverar que el cuerpo, allende su carácter pretendidamente natural, resiste múltiples gramáticas. Más allá de las distintas pretensiones teóricas de fijarle al organismo humano una sola sintaxis -sean estas pretensiones de carácter médico, sexológico, psicoanalítico o criminológico-, la imagen de un cuerpo desnudo, en estado de naturaleza, es conveniente en términos del poder social en tanto legitima la instauración de normas corporales como si fuesen necesarias. En otras palabras, la ficción de un cuerpo presocial funciona a la manera de una mampara que faculta a una serie de saberes y dispositivos de control corporal a ejercer su influencia sin admitir su contingencia. En el caso de las teorías sobre la moda, la ausencia de una problematización con respecto a la influencia del vestido en la instauración de unas determinadas gramáticas corporales en desmedro de otras acaba reduciendo nuestro fenómeno a una especie de continuación cultural de las luchas biológicas antes descritas. Es precisamente esa marginada dimensión teórica de la moda la que pondré de relieve a lo largo de las páginas siguientes.

\subsection{El cuerpo desnudo como consecuencia del cuerpo vestido: hacia un análisis de la moda como mecanismo de poder corporal}

Desde mi perspectiva, la oposición entre el cuerpo vestido y el cuerpo desnudo funciona en el universo de las teorías sobre la moda como un criterio legitimante de mecanismos 
de control social. Partiendo de una comprensión de lo corporal proveniente de saberes como los discutidos en el apartado anterior, el cuerpo desnudo, presuntamente desprovisto de signos que lo culturalicen, se considera en las teorías sobre vestido como una substancia presocial. De esta manera, la desnudez opera al interior de la filosofía de la moda como un punto de partida heurístico que se da por sentado.

Sin embargo, cabe cuestionar tal visión de la desnudez. Para Agamben, por ejemplo, "[la] desnudez y [la] naturaleza son, como tales, imposibles [pues] existe solo la puesta al desnudo" ([1999] 2011, 104). En otras palabras, el cuerpo desnudo, en tanto entidad natural, es para este autor resultado de un dispositivo cultural y no a la inversa. Según Agamben, habría que desmontar la visión canónica de la desnudez para mostrar que esta última no constituye un estado previo al cuerpo vestido sino que, por el contrario, es el cuerpo desnudo el que supone ontológicamente hablando la vestimenta. En otras palabras, según este enfoque, el cuerpo desnudo no existe más que como resultado de una serie de discursos que lo enuncian. La desnudez contiene, así, una positividad: no es meramente privación (Agamben, [1999] 2011, 102- 104). De este modo, mientras que el cuerpo vestido pasa inadvertido puesto que los organismos inevitablemente comportan una presentación o una apariencia, la desnudez, en cambio, requiere de un registro que la haga posible. La desnudez, en síntesis, solo existe para Agamben como presupuesto, como desnudamiento; no existe una desnudez presocial, lo que existe es la institución social del desnudo. Solo hay desnudez, por tanto, en el marco de un entramado discursivo que la postule.

En la filosofía de la moda tal postulación de hecho ocurre. El cuerpo desnudo se erige en las teorizaciones sobre el vestido como el receptáculo presocial de las prendas. Bajo los preceptos de la biología y el psicoanálisis, el cuerpo de los teóricos de la moda pertenece simultáneamente a dos registros ontológicos: es lo natural por excelencia (cuerpo desnudo), pero al mismo tiempo constituye un lugar de intervención privilegiado (cuerpo vestido). No obstante, el cuerpo de la moda no solo participa de esos dos registros ontológicos (natural y cultural), sino que además constituye, a través de las metáfroas bélicas antes estudiadas, uno de sus puntos de intersección más importantes. 
En la filosofía de la moda, esa extraña condición del cuerpo se encuentra sintetizada de forma paradigmática en la fórmula de Flügel citada anteriormente según la cual no existen pueblos que no se decoren (Flügel, [1930] 1964, 14). ${ }^{10}$ En el cuerpo, según Flügel (aunque se trata de una opinión compartida por la mayoría de teóricos de la moda), la decoración viene a ser, de hecho, una segunda piel, y por lo tanto una segunda naturaleza, pero paradójicamente se trata de una naturaleza del orden de lo cultural. El vestir y la moda, según Flügel son fenómenos que introducen en el cuerpo la cultura, pero al mismo tiempo, lo decorativo constituiría una necesidad que viene dada por la naturaleza de la especie. Mientras que en Freud se encuentran superpuestas dos tesis una según la cual el cuerpo y la sexualidad se encuentran constreñidos por un entorno social que admite negociaciones pero que también impone límites represivos y contingentes al deseo, y otra según la cual la anatomía es destino, en razón de lo cual los cuerpos se encuentran marcados por una naturaleza que establece ciertas barreras infranqueables (Freud, [1905] 2013)-, en el análisis psicoanalítico del vestido ese carácter liminar del cuerpo biológico es manifiesto. ${ }^{11}$ Los límites que la cultura impone a la libido y al cuerpo sexuado son para la economía freudiana del deseo impugnables dentro de cierto margen, pero dichos límites tienden a encontrar en el cuerpo, entendido como naturaleza, una frontera frente a la cual cualquier esfuerzo de "resignificación" es imposible. ${ }^{12}$ Así ocurre también en la teoría del vestido de Flügel. En otras palabras, el cuerpo psicoanalítico queda, no solo para Freud, sino para los psicoanalistas del vestido, preso en los confines de la biología. Según Flügel, la represión generada a través de la vestimenta tiene su génesis en algunas características psíquicas de los sujetos, pero su

\footnotetext{
${ }^{10}$ Véase al respecto el apartado 1.3.

${ }^{11}$ Sobre la idea de la anatomía como destino en Freud, véase Irigaray ([1974] 1978, 48-58).

${ }^{12}$ El concepto de resignificación tal y como lo postula la filósofa estaduounidense Judith Butler ([2004] 2006, 315-320) nos pone frente a los límites impuestos por el psicoanálisis al cuerpo, o en otras palabras, frente a la cuestión de hasta dónde llegan los límites de lo que en el psicoanálisis es susceptible de ser reformulado en términos simbólicos (aunque, valga aclararlo, la noción de resignificación no remite en primera instancia a apropiaciones referidas a normas psiconalíticas, sino, en términos generales, a cierto tipo de apropiación performativa fundamentalmente de carácter lingüístico -volveré en breve sobre el concepto de performatividad - que subvierte los códigos generales con que están estructuradas las normas sociales). Para una muestra del modo en que se ha dado contemporáneamente el debate de hasta qué punto el psicoanálisis admite la resignificación de las normas sociales, así como de los efectos de dicho debate para los movimientos sociales en la actualidad, véase Contingencia, hegemonía, universalidad (Butler, Laclau y Žižek, [2000] 2011, 145). Véase, asimismo, la crítica butleriana a Lacan en Cuerpos que importan ([1993] 2008, 146-168).
} 
origen último está en el vestido mismo. ¿La solución?: el nudismo. Para Flügel, en efecto, los problemas que supone la moda para la economía libidinal del sujeto se podrían resolver con el solo hecho de que la sociedad prescindiera del vestido. La teoría del vestido psicoanalítica encuentra su frontera última, así, en el cuerpo biológicamente considerado: "nuestro cuerpo con todas sus imperfecciones [señala Flugel], persiste debajo [y] constituye un elemento más esencial, permanente e ineludible de nuestro ser que nustras ropas" (Flügel, [1930] 1964, 291). La liberación definitiva en el ámbito vestimentario, así, no puede consistir dentro de un marco psicoanalítico más que en un nudismo hasta cierto punto naive, pues soslaya el hecho de que el cuerpo desnudo en sí mismo ya está en/vestido de una serie de significaciones. El cuerpo desnudo implica la vuelta a unos orígenes anteriores a cualquier forma de represión vestimentaria (¿y anteriores a la cultura?), y en esa medida, no tiene sentido hablar de una liberación del cuerpo desnudo porque el cuerpo desnudo es en sí mismo ya un cuerpo libre. Así, según Flügel: "la reconciliación completa con el cuerpo significaría que las variaciones, correcciones y agrandamientos estéticos del cuerpo producidos por las ropas ya no se sentirán como necesarios o deseables; de hecho, no habrá necesidad de ropas” ([1930] 1964, 307).

En última instancia, las limitaciones de la teoría psicoanalítica del vestido son las mismas que Foucault detectó en la teoría freudiana del deseo: en ambas se considera que hay una esencia que aguarda quedamente su liberación, $y$, por lo tanto, ambas teorías asumen que basta con quitar los grilletes, ya sea al cuerpo o al deseo, para que la libertad emerja a través de sus propios resortes. Así, el cuerpo desnudo es para los psicoanalistas de la moda, lo que la anatomía para Freud, a saber: un punto de partida heurístico. En términos foucaultianos la categoría de desnudez, tal y como funciona dentro de la filosofía psicoanalítica del vestido, podría entonces ser entendida como una realidad transaccional, es decir, como una especie de operador de intercambios a través del cual se relacionan prácticas y conceptos, y se articulan e interceptan discursos heterogéneos (Foucault, [2004] 2010, 337). En síntesis, el cuerpo funge, en el marco de la filosofía psicoanalítica de la moda, como un punto de anclaje teórico para un conjunto de ideas diversas sobre la 
naturaleza y la cultura, a la vez escenario de guerras evolutivas y de luchas por la distinción social.

Tanto en la aproximación psicoanalítica al tema del vestido como en la del resto de las filosofías de la moda (o más aún en ellas puesto que en casos paradigmáticos como el de Veblen y Simmel la concepción de cuerpo que se utiliza proviene directamente de la biología evolucionista de Spencer), lo corpóreo aparece como una superficie pretendidamente natural que las prendas se encargan de recubrir y por lo tanto de codificar. El cuerpo desnudo es necesario en la filosofía psicoanalítica de la moda en particular, y en la filosofía de la moda en general, como un comienzo: como punto de partida a partir del cual la sociedad comienza a intervenir el cuerpo -o bien a reprimirlo, según reza la fórmula psicoanalítica-.

Si en la filosofía psicoanalítica de la moda el cuerpo se considera una substancia reprimida, en el resto de teorías sobre el vestido sucede, de hecho, algo similar: las prendas cubren un cuerpo cuya constitución viene dada por la naturaleza biológica del ser humano -pese a que la comprensión biológica del cuerpo ya contiene en sí misma presupuestos culturales; véase al respecto al análisis del historiador del sexo Thomas Laqueur ([1990] 1994)-. Así, la moda aparece como problema a condición de que el cuerpo vestido surja ontológicamente hablando del cuerpo desnudo y de que este último sea conceptualizado en términos metafísicos como una substancia que aguarda ser maniobrada culturalmente. El cuerpo desnudo, de esta manera, se conceptualiza como una suerte de nueva tabula rasa en la que la cultura se despliega como texto.

Quizá donde esto se torne más evidente es en la filosofía estructuralista del vestido, donde el problema central en torno a la moda es decodificar los significados que esta inscribe sobre el cuerpo, rechazando la aparente naturaleza arbitraria de aquellos. Para Barthes, en efecto, "el sistema del vestido real nunca es otra cosa que el horizonte natural que la moda traza para constituir sus significados" (Barthes, [1967] 2003a, 14). Así, según el autor, el cuerpo es la superficie de escritura del código que el semiólogo estructuralista ha de descifrar. De ese modo, se consideran arbitrarios los códigos que la 
moda impone sobre el cuerpo, pero no se repara en las transformaciones materiales de las que el propio cuerpo es objeto a través de la moda. El estructuralismo parte, pues, de un cuerpo desnudo que soporta una serie de codificaciones externas mediante los vestidos, pero que no permite reparar en la posibilidad de que esas codificaciones afecten la constitución del organismo.

De este modo, asumir que el cuerpo desnudo es naturaleza autoriza a reclamar su intervención dentro de un marco en el que está decidido de antemano qué cuenta como un cuerpo humano y qué no (y, por lo tanto, qué es transformable y acetable en dicho cuerpo o, por el contrario, que está dado de una vez por todas en él). En tal sentido, como lo apunta Butler,

[...] el cuerpo postulado como anterior al signo es siempre postulado o significado como previo. Esta significación produce, como un efecto de su propio procedimiento, el cuerpo mismo que, sin embargo y simultáneamente, la significación afirma descubrir como aquello que precede a su propia acción (Butler, [1993] 2008, 57).

La desnudez de la que parten los teóricos del vestido supone, así, un núcleo no problematizado (dentro del cual, como sostendré más adelante, el binarismo sexual resulta fundamental) que, sin embargo, define de entrada qué es conceptualizable como cuerpo y qué no. De este modo, el cuerpo vestido, en conformidad con su pretendida raigambre biológica y las concomitantes batallas evolutivas que libra, instaura una cierta gramática corporal como si esta fuese natural, quedando así marginada de la discusión teórica la pregunta a propósito del impacto que la moda tiene en los organismos.

Para los efectos del presente estudio, la limitación más importante de esta conceptualización del cuerpo es el modo en que renuncia a comprender una serie de prácticas de poder que tienen lugar de la mano de la moda. La situación del cuerpo desnudo es en este sentido similar a la descrita por Foucault en torno a la locura: así como "puede decirse que la locura 'no existe', pero eso no quiere decir que no sea nada" (Foucault, [2004] 2009, 143), también puede decirse que la comprensión del cuerpo desnudo como reducto natural a la espera de vestidos, lejos de "ser nada", es un 
dispositivo conceptual que ha fijado un canon de problemas en torno a lo indumentario unilaterlamente centrado en el problema de la difusión -en desmedro de un análisis que podría ver en la moda, ante todo, un conjunto de prácticas disciplinarias y de mecanismos de control biopolítico en torno a los cuales tienen lugar diferentes ejercicios de poder normalizante (ampliaré todas estas cuestiones en los próximos dos capítulos)-.

Mi pretensión, más allá de esa grilla de inteligibilidad fijada por la filosofía de la moda a partir del tropo del cuerpo desnudo y de las metáforas bélicas es, por tanto, analizar la moda en tanto mecanismo de poder que, lejos de recubrir un cuerpo ya dado, contribuye junto a otros regímenes de control social, a producir ese cuerpo. De esta forma, la filosofía de la moda se revela, antes como un régimen discursivo que legitima una serie de artimañas relacionadas al control corporal y a la aplicación de diversos mecanismos disciplinarios en torno al organismo, que como un saber teórico meramente descriptivo del fenómeno vestimentario.

\subsection{El cuerpo, el vestido y la labilidad de unas fronteras}

Desestabilizar la sintaxis pretendidamente natural impuesta al cuerpo desnudo y su influencia en la comprensión de la moda como una especie de lucha por la distinción, implica reconceptualizar el cuerpo como una superficie en la cual tienen lugar una serie de intercambios, conexiones, flujos, transformaciones, gestaciones, disoluciones y mutaciones. En ese sentido, considero necesario oponer al cuerpo presocial de la filosofía de la moda un cuerpo entendido no como una materia estable sino como una superficie continuamente manipulada (por uno mismo y por otros) cuya frágil estabilidad depende de lo que en términos butlerianos podríamos llamar su modelación performativa (Butler, [1990] 2007, 264- 266). La performatividad, que en principio designa una propiedad de la lengua de proveer de una consistencia ontológica a aquello que se designa mediante el propio acto de la enunciación, se refiere, en este contexto, a la propiedad del cuerpo de actualizar y consolidar unas normas que paradójicamente no lo anteceden. En El género en disputa ([1990] 2007) Butler subraya ese carácter irreductiblemente performativo del 
cuerpo y habla con Foucault del alma "como una carencia significante" ([1990] 2007, 64). Siguiendo a Foucault, Butler afirma que el cuerpo es, en efecto, modelado a partir de ideales de subjetividad que lo informan. En otras palabras, a través de arquetipos metafísicos, los cuerpos son objeto de una serie de transformaciones que ocurren a lo largo del tiempo (volveré sobre este carácter normalizante de la moda en el próximo capítulo). Si los límites del cuerpo son inestables, la ficción de una interioridad consolidada permite pensar ciertas morfologías coporales como naturales sin reparar en que las mismas han sido gestadas sociohistóricamente.

Butler destaca el hecho de que, a partir de este marco, la idea de un cuerpo natural está escencialmente ligada al binarismo de género como realidad presuntamente biológica aunque como lo ha mostrado Laqueur no hay sexos biológicos sin un discurso sobre los géneros que lo anteceda; véase Laqueur ([1990] 1994, 33). El binarismo sexual, así, se erige como una verdad del sujeto que imprime con fuerza unas ciertos contornos en la anatomía. De este modo, la subjetividad y el cuerpo quedan íntimamente ligadas por efecto de un conjunto de "actos, gestos y realizaciones — por lo general interpretados[que] son performativos en el sentido de que la escencia o la identidad que pretenden afirmar son invenciones fabricadas [manufactured fabrications] y preservadas mediante signos corpóreos y otros medios discursivos" (Butler, [1990] 2007, 266).

De este modo, el performativo supone un ejercicio de imitación de una fantasía idealizada que no tiene original, y es en virtud de esa repetición ritualizada que se funda y consolida el sujeto. El cuerpo, desde esta perspectiva, es entonces una superficie inestable en la cual acaecen permanentemente una serie de transformaciones. En otras palabras, según Butler, la corporalidad se sostiene sobre la base de una manutención individual y cultural y no constituye ninguna esencia que permanezca por debajo de las permutaciones que dicha manutención involucra.

Llevando a sus últimas consecuencias las intuiciones butleriana considero plausible señalar que, en rigor, cuando un cuerpo deja de ser trabajado -esto es: alimentado, vestido, curado, y en términos generales atendido-, muere. Los cuerpos requieren, desde 
mi perspectiva, de un cuidado que abarca su nutrición y curación, pero que también incluye su embellecimiento, decoración, cubrimiento, descubrimiento y estilización (sobre este último concepto volveré in extenso en el capítulo 5). Foucault señala al respecto que todos esos procesos de cuido constituyen, de hecho, instancias de subjetivación (es decir, procedimientos a partir de los cuales se hace posible la construcción de subjetividades), en razón de lo cual cabe, a partir de este perspectiva, desechar versiones fundacionalistas tanto en relación con la subjetividad como con el cuerpo. ${ }^{13} \mathrm{Ni}$ el cuerpo ni el sujeto, en esta medida, son anteriores a la cultura. En otras palabras, es a través de los procesos de gestión y cuido del cuerpo y de sí que emergen los sujetos. Estos procesos de cuido, por lo tanto, no se limitan a variar la apariencia de un cuerpo que permanecería inalterable detrás de todas esas maniobras -tal y como lo sostienen los filósofos de la moda-, ${ }^{14}$ sino que, por el contrario, dichos procesos transforman la corporalidad en su materialidad, modelando sus contornos, superficies, tonalidades y consistencia.

A partir de esta manera de concebir el cuerpo por parte de Foucault y Butler sugiero, pues, pensar la moda como un mecanismo de gestión somática. Dado este carácter ontológicamente incierto del cuerpo cabe, en efecto, pensar lo corporal como una superficie en permanente cambio y en contínua modificación de sus límites. En este sentido, la moda puede ser considerada una herramienta de administración del cuerpo que, sin embargo, se inscribe en el mismo. En otras palabras, la prenda no cubre un cuerpo dado, sino que, al introducirse en un cuerpo vivo, conforma una unidad con él. Tal y como lo señala el fenomenólogo francés Merleau-Ponty, el cuerpo (contrariamente a como lo afirma cierta perspectiva científica ususalmente aceptada que intenta disecar el organismo y sus movimientos a fin de comprenderlo) constituye un organismo viviente (Merleau-Ponty, [1945] 2000, 215). Según Merleau-Ponty, el cuerpo, de hecho, se encuentra siempre en situación y ese carácter relacional de lo corporal en relación con el entorno se da de forma viva: "mis vestidos [indica el autor] pueden convertirse como en

\footnotetext{
${ }^{13}$ Sobre la relación entre el cuido de sí en tanto instancia de subjetivación y forma de atender el cuerpo véase Foucault ([1984] 2004, 95). Véase también el seminario La hermenéutica del sujeto, donde el filósofo francés examina los avatares históricos del tema del cuido de sí en la filosofía griega y la latina. Ampliaré estas tesis en el capítulo 5.

${ }^{14}$ Para un ejemplo explícito de esta posición véase Saulquin, quien considera que las modas deseables son aquellas que rescatan el ser por sobre el parecer $(2010,159-160)$.
} 
los anexos de mi cuerpo" (Merleau-Ponty, [1945] 2000, 108). En este sentido, cabe distanciarse también de la ficción de un cuerpo idéntico a sí mismo y opuesto a su entorno. El cuerpo se encuentra, por el contrario, en tensión permanente con el mundo, en razón de lo cual sus fronteras son bastante más lábiles de lo que se cree. Si el cuerpo, como lo afirma Merleau-Ponty, se despliega en el mundo, habría entonces que dudar de ese esquematismo de los filósofos de la moda que pretenden separar tajantemente el cuerpo desnudo de los dispositivos vestimentarios que lo recubren (me detendré en la comprensión mereleau-pontyana del cuerpo en el capítulo 5). En tal sentido, me parece que a la hora de examinar la moda conviene pensar el cuerpo como una superficie que negocia culturalmente sus fronteras y que, en tal sentido, se descompone, recompone, identifica, clasifica, potencia y despotencia a partir de su interacción con insumos culturales como el vestido.

En razón de lo anterior, como lo señala el filósofo francés Jean Luc Nancy, no tiene sentido hablar de un cuerpo unitario y cerrado. Para Nancy, efectivamente, lo propio del cuerpo es justamente la intrusión: la interacción con un entorno en relación con el cual el sujeto se integra y desintegra permanentemente ([2000] 2007, 45). En esta línea, Nancy pone de relieve el carácter negociable de los límites del cuerpo: "los cuerpos no son de lo 'pleno', del espacio lleno (el espacio está por doquier lleno): son el espacio abierto" ([2000] 2010, 16). En tal sentido, Nancy entiende el cuerpo justamente como "la tópica de todos sus accesos, de sus aquí/ahí, sus fort/da, sus idas y venidas, tragar y escupir, inspirar/expirar, abro y cierro" ([2000] 2010, 42). El autor se refiere, así, a un cuerpo y un yo ajenos a sí mismos, en razón de lo cual, afirma el filósofo, "la verdad del sujeto es su exterioridad y su excesividad: su exposición infinita" (Nancy, [2000] 2007, 43). La relación del yo con el cuerpo, según Nancy, es, por tanto, una relación compleja, rica y tirante. Asimismo, la relación del cuerpo con los elementos a partir de los cuales se trabaja el mismo es una relación caleidoscópica: el cuerpo está en permanente tensión con aquello que lo sana, que lo equilibra, que lo interpela. El cuerpo, de esta manera, no es anterior a la política: "la política ya no sería una cuestión de sentido incorporado: sino que la política comienza y termina en los cuerpos" (Nancy, [2000] 2010, 52). Siguiendo esta perspectiva, considero que las relaciones entre el cuerpo y el vestido no conforman 
una unidad fija: las características de sus interacciones, por el contrario son histórica y políticamente administradas y, por lo tanto, contingentes y variables. Si el cuerpo, al estar sometido permanentemente al influjo de la cultura (trátese de procesos médicos, prácticas sexuales o regímenes alimenticios), rechaza un origen unitario y un telos predeterminado, entonces la moda puede ser interpretada como una herramienta cultural que resulta fundamental, tanto a la hora moldear el cuerpo (véanse los capítulos 3 y 4 de este escrito), como a la hora de intentar producir experiencias de agenciamiento en torno al mismo (véanse capítulos 5, 6 y 7).

En este sentido, alrededor de la moda conviene tener en mente la interrogante de Butler a partir de la cual la autora inquiere a propósito de aquello que se excluye del cuerpo para formar los límites del mismo (Butler, [1993] 2008, 106). En otras palabras, en relación con la vida corporal conviene tener presente que existen una serie de parámetros que rigen lo "materializable" y que fijan una frontera respecto de lo que cuenta como cuerpo y lo que no. Es por eso que en los capítulos siguientes el género, en tanto matriz de inteligibilidad fundacional, tendrá un papel protagónico. El binarismo sexual será, de hecho, presentado como una grilla de inteligibilidad que sustenta una cierta antropología filosófica que la filosofía de la moda da por sentada. Al mismo tiempo, el binarismo sexual justifica epistémicamente hablando -en tanto pretendida verdad natural del cuerpo- una serie de procedimientos de control vestimentario. Al analizar la moda en tanto forma de poder, por tanto, el binarismo de género aparece como fundamento del cuerpo natural -en la medida en que, como lo sugiere Irigaray, la diferencia sexual constituye una matriz de inteligibilidad por excelencia en Occidente- y como sustento de una noción biologicista de sujeto. El cuerpo desnudo de la filosofía de la moda al que me he referido en este capítulo, es de hecho, un cuerpo sexuado desde su propio origen. La vestimenta, que en principio se concibe como mero añadido al cuerpo, resulta así un dispositivo central dentro de los mecanismos de control corporal en la medida en que permite desplegar performativamente un género $\mathrm{y}$, así, devenir legible como sujeto (volveré sobre este tema en el próximo capítulo). 
En este sentido, la prenda, en tanto prótesis o añadido que se inserta al cuerpo y pasa a formar parte de él -y ya no en tanto elemento semiótico o emblema de clase que se limita a comunicar el prestigio de su portador-, también resultará central en la reflexión que desarrollaré posteriormente. La prenda muestra, en efecto, que lo que se excluye e incluye del cuerpo (y dentro de la noción misma de cuerpo) es objeto de una permanente negociación. Los recortes, transformaciones y adiciones que se realizan al cuerpo mediante la moda (es decir, mediante los diferentes procedimientos de transformación que esta abaraca: tatuajes, accesorios, peinados, maquillajes, vestidos, cirugías estéticas, etc.) constituyen operaciones corporales que desdibujan la frontera de lo artificial y lo natural. Los cuerpos, así, están siendo objeto de manipulación artificial de forma permanente, y en esa medida, lo corporal podría entenderse justamente como esa realidad cambiante, polimorfa e inestable que surge como resultado de continuas tranformaciones materiales. En tal sentido, cabe sostener que la prenda contribuye, junto a otros dispositivos, a hacer el cuerpo.

Así, mi tesis es que en el cuerpo, todo es prótesis, en el sentido de que la totalidad del cuerpo viviente está siendo sometida contínuamente a procedimientos de tratamiento artificial aún antes del propio nacimiento. El cuerpo, en este sentido, no es nada sin el conjunto de aditamentos que le permiten pervivir y permanecer a lo largo del tiempo. Dentro de una perspectiva similar a esta, la teórica queer Beatriz Preciado suministra la imagen del falo como imitación del dildo para poner en evidencia el proceso mimético a partir del cual lo natural, al no tener referente real, imita lo artificial ([2000] 2011, 11-12). En otras palabras, según Preciado, el cuerpo sexuado se administra en relación con un referente estructural -el falo- que no existe como naturaleza sino solo como ideal artificial. Considero necesario, sin embargo, descentrar esa inversión mimética notablemente falocéntrica para considerar el cuerpo en su totalidad, y no únicamente el falo, como el resultado de operaciones prostéticas. En esa medida, cabría considerar el vestido un tipo de prótesis y la moda una instancia de administración del cuerpo en relación con dichas posibilidades prostéticas. 
Renunciar a la comprensión del cuerpo desnudo entendido como naturaleza implica, pues, pasar de ver la moda como un problema de consumo y de lujo (es decir, como una problemática que se agotaría en el asunto de la difusión) a ver en ella un conjunto de técnicas. ${ }^{15} \mathrm{Al}$ entender la moda como un conjunto de técnicas dirigidas al cuerpo, intento, por lo tanto, reconocer la inestabilidad constitutiva de éste. En tanto superficie continuamente manipulada a través de técnicas, el cuerpo se revela, desde la perspectiva que deseo emplear acá, como un constructo de cierta precariedad ontológica. Ello explica, finalmente, el porqué las distintas filosofías de la moda han recurrido a una noción anatomobiológica del cuerpo: dicha concepción provee un punto de partida ontológico para poder discurrir en torno a los vestidos. Mi intención acá, por el contrario, es aproximarme al tema de la moda poniendo el énfasis en las técnicas discursivas y políticas que tienen por efecto la producción del cuerpo. En este sentido, mi análisis pretende aproximarse a la moda como una importante técnica dirigida a la modelación del cuerpo, en lugar de presentarla, como se suele hacer, como una simple institución frívola asociada al encantamiento moderno por el cambio y el despilfarro.

\footnotetext{
${ }^{15}$ Con el concepto de "técnicas" me refiero, siguiendo a Foucault, no únicamente a los mecanismos mediante los cuales se manipulan y transforman los objetos y los símbolos, sino también a los procedimientos a través de los cuales se dirige la conducta de otros o se llevan a cabo transformaciones del propio cuerpo y de la propia alma para alcanzar un fin determinado (Foucault, [1998] 2008, 48). Aunque en la moda se encuentran implicadas técnicas del primer tipo (por ejemplo en torno a los circuitos de producción de prendas o de campañas publicitarias) me centraré en lo sucesivo en el análisis de la moda entendida como tecnología gubernamental, es decir, como un dispositivo de transformación y gestión material del cuerpo-. Para un análisis de la moda como tecnología de producción puede verse El cuerpo y la moda de Joanne Entwistle ([2000] 2002). La obra de Barthes, por otra parte, lleva a cabo un análisis en torno a la moda en términos de una tecnología de producción de signos ([1967] 2003).
} 


\section{SEGUNDA PARTE \\ Descifrar las artimañas}

"sólo los ingenuos pueden ignorar, después de tantos trabajos históricos sobre la simbólica del poder, que las modas en el vestido y en la cosmética constituyen un elemento capital del modo de dominación"

P. Bourdieu, La distinción, 365 


\section{Capítulo 3. Moda y disciplinamiento}

En los capítulos anteriores he argumentado que las teorizaciones a propósito de la moda parten del cuerpo como una superficie dada, recubierta por unos vestidos que supuestamente no alteran su constitución sino únicamente su aspecto. Esas teorizaciones asumen que el cuerpo es una substancia presocial, independiente de las prendas que lo recubren. Dicho presupuesto epistemológico, como he intentado mostrarlo, ha establecido dentro de la literatura sobre moda un canon de problemas que se ha mantenido relativamente estable desde que se publicaran las obras fundacionales en relación con nuestro tema (me refiero a los estudios de Simmel y Veblen). De ese modo, los teóricos del vestido han centrado sus análisis fundamentalmente alrededor del asunto de la difusión y han hecho orbitar alrededor del mismo un conjunto adicional de temáticas: el carácter comunicativo de los vestidos, el problema de la emulación, la cuestión de la identidad y el tópico de la distinción de clase; todo ello a partir de una serie de supuestos antropológicos a mi juicio no suficientemente problematizados.

En lugar de partir de una concepción del cuerpo en tanto que substancia y de la moda como un simple canon estético que orienta las variaciones en el aspecto, mi intención en este capítulo, por el contrario, es construir un marco en el que el cuerpo se considere culturalmente construido y en el que la moda se aborde como una de las prácticas de poder destinadas a llevar a cabo dicha construcción. En esa medida, considero que el asunto del vestido desborda el problema de la difusión y constituye una temática que involucra algo más que caprichos y curiosidades epocales. A partir de esta perspectiva, cabe en efecto la sospecha de que tras la aparente frivolidad de la moda se urden complejos mecanismos que definen normas somáticas y crean mecanismos reglamentadores, sistemas identificatorios, dispositivos de disciplinamiento, regímenes de deseo y modos de relacionamiento con el propio cuerpo y con el cuerpo de los otros. Todos estos dispositivos de poder, sin embargo, se encuentran disimulados por un ideal antropológico que subyace a la filosofía de la moda y que implica también una filosofía del cuerpo. En efecto, tal y como lo he indicado en el capítulo anterior, los estudiosos de 
la moda recurren a la biología y la anatomía para "describir" el cuerpo desnudo que sirve como fundamento heurístico a sus teorías. Ese cuerpo "natural" que, permeado de darwinismo, es imaginado como propio de una especie en guerra, funciona como basamento antropológico en la filosofía de la moda. Por mi parte, siguiendo la premisa foucaultiana de que tras el "sueño antropológico" aguardan esencias que imponen un límite a toda empresa crítica, ${ }^{16}$ mi intención en este capítulo es analizar los efectos que ese núcleo antropológico propio de la filosofía de la moda tiene sobre el cuerpo.

En esta medida, y en continuidad con lo señalado en los capítulos anteriores, en este capítulo examinaré algunas de las objeciones que se han realizado al ideal de un cuerpo sexuado como núcleo antropológico fundacional y como basamento del ideal de un organismo natural. Específicamente retomaré algunas de las críticas feministas al ideal del sexo dicotómico para, a partir de ellas, intentar poner de relieve el rol disciplinario que el binarismo sexual juega en el campo del vestido. Del mismo modo, intentaré conceptualizar las prendas en términos de dispositivos de disciplinamiento corporal. Posteriormente expondré esa vocación disciplinaria de la moda a través de algunos casos históricos. Por último, mostraré cómo el disciplinamiento vestimentario se articula con mecanismos de normalización corporal, posibilitando un régimen de deseo particular (a saber, lo que la feminista Adrienne Rich denomina heterosexualidad obligatoria).

En suma, se trata de perfilar la moda ya no como un asunto de consumo cuyo carácter teóricamente problemático se agota en la cuestión de la difusión, sino de comprender la vestimenta como un mecanismo de poder que ejerce una buena dosis de influencia sobre las subjetividades y los cuerpos.

\footnotetext{
${ }^{16}$ En Una lectura de Kant: introducción a la antropología en sentido pragmático Foucault indica que "al desembarazarse de una crítica previa del conocimiento y de una pregunta primera sobre la relación con el objeto, la filosofía no se ha liberado de la subjetividad como tesis fundamental y punto de partida de su reflexión. Por el contrario, se ha encerrado en ella al dársela espesada, hipostasiada y clausurada en la insuperable estructura de la "menschkliches sen" [esencia humana], en la cual vela y se recoge silenciosamente esta verdad extenuada que es la verdad de la verdad" (Foucault, 2009, 130). Para Foucault, esa subjetividad hipostasiada constituye una suerte de "ilusión" o "sueño antropológico" (Foucault, 2009, 129; 2002a, 353-355) que limita los proyectos críticos de la filosofía.
} 


\subsection{EI vestido y la diferencia sexual}

En el siglo XIX un profesor de estética denunciaba la crinolina por hacer "una idea totalmente falsa del cuerpo femenino" (Gavarrón, 1997, 155). La idea de un cuerpo "verdadero" o "natural", ya sea que se considere pervertido o debidamente salvaguardado por la cultura, es de hecho un tópico que puede encontrarse reiteradamente a lo largo de la historia del vestido más allá de este ejemplo concreto. El movimiento impulsado por Mrs. Bloomer en 1851 a favor de la utilización de un vestido más racional para las mujeres (Laver, [1982] 2008, 182), el llamado flügeliano a racionalizar la moda (Flügel, 1964, 283-295), el sostén diseñado por William Rosenthal en 1926 para inmovilizar los pechos femeninos en su posición "natural" (Yalom, 1997, 210) y la innumerable cantidad de dispositivos ortopédicos que los pedagogos pusieron en práctica desde el siglo XVI en aras de "enderezar" el cuerpo de los niños (Vigarello, [2001] 2005), constituyen algunos ejemplos al respecto. En todos esos casos la racionalidad de los vestidos dependía de su adecuación a lo que se consideraba la estructura "natural” y "verdadera" del cuerpo.

Más allá de los disímiles propósitos para los que ha sido empleada esta idea del cuerpo como un cuerpo verdadero, lo cierto es que hablar en estos términos equivale a inscribir la moda, en un sentido foucaultiano, dentro de un régimen de verdad. Con esto quiero decir que la moda, además de reparar en cuestiones estéticas (decoración) y funcionales (protección), atiende siempre cierto principio de racionalidad. En otras palabras, las prendas no se ponen de moda sin que medie algún tipo de legitimación de su belleza, adecuación o practicidad. En este sentido, toda moda involucra un proceso de racionalización a través del cual el cuerpo se somete a diversas formas de disciplinamiento en aras de que asuma una morfología determinada. Sin embargo, como argumentaré a continuación, paradójicamente la moda también es responsable de sedimentar esas formas de racionalidad que la impulsan.

¿En qué consiste, pues, esa verdad del cuerpo a la que la moda se atiene pero que simultáneamente contribuye a formular? Si bien es cierto que los procedimientos discursivos que pretenden imponer una sintaxis al cuerpo mutan históricamente y 
encuentran su fundamento en una amplia gama de saberes, también lo es que todos ellos remiten las verdades corporales al ámbito de la naturaleza. En el caso de la episteme moderna de la cual las filosofías de la moda forman parte, el cuerpo desnudo posee, como lo señalé en el capítulo anterior, una sintaxis que se le supone inmanente por vía de los saberes anatómico y biológico. Los cuerpos desnudos, imaginados dentro de un continuum evolutivo de la especie, son concebidos, así, como cuerpos naturales.

Sin embargo, si tal y como lo señalé antes a partir de Agamben no existe un cuerpo desnudo de carácter presocial, cabe entonces preguntar de qué manera las prendas producen o contribuyen a producir esa supuesta verdad de un cuerpo "natural". Responder a esa interrogante supone remontarse al punto de partida ontológico a partir del cual emergen tanto el cuerpo vestido como el ideal del cuerpo natural. A saber: la diferencia sexual.

En efecto, el cuerpo desnudo es un cuerpo que se concibe, por definición, como un cuerpo sexuado. Si bien es cierto que los ardides discursivos que asignan una naturaleza al cuerpo varían a lo largo del tiempo, se superponen unos con otros, cambian su clave de enunciación -ya sea que, por ejemplo, pasen de la moral a la ciencia, o de la religión a la higiene-, lo cierto es que todos ellos encuentran en la diferencia sexual un fundamento primordial. Partiendo de aguda relectura foucaultiana de Platón según la cual el alma es un principio ontológico que informa el cuerpo (Foucault, [1975] 2008, 39), y de la tesis de Irigaray según la cual todas las teorías del sujeto desde Platón en más se erigen sobre la negación de lo femenino (Irigaray, [1974] 1978,149-164), considero, en efecto, que la diferencia sexual es un dispositivo que dota de legibilidad a los cuerpos y a las subjetividades de forma constante a lo largo de la historia occidental. De hecho, cuando las verdades del cuerpo se encuentran comprometidas, los saberes que las enuncian recurren a la diferencia sexual como un núcleo ontológico incontrovertible. En otras palabras, la diferencia sexual aparece como una grilla de inteligibilidad particularmente poderosa a la hora de percibir los cuerpos.

En el ámbito de las reflexiones a propósito de la moda, esto se traduce en el hecho de que 
la diferencia sexual confiere al cuerpo un estatuto ontológico estable, lo cual queda evidenciado en el abordaje que los teóricos del vestido realizan en torno a la relación entre la vestimenta y la diferencia sexual.

El connotado historiador de la moda James Laver, por ejemplo, al interrogarse sobre la posibilidad de establecer un criterio de ingreso que pueda orientar los estudios enfocados en el vestido, propone el sexo como el criterio de ordenación historiográfico más evidente (Laver, [1982] 2008, 9). La mayoría de las distintas aproximaciones teóricas al tema de la moda sostienen, de hecho, una postura similar. Sin importar si se trata de estudios sociológicos, semiológicos, psicológicos o históricos, la división sexual se torna en los estudios clásicos sobre la moda como un fundamento epistémico. Lurie, por ejemplo, opina que la ropa se revela el sexo al cual pertenece cada quien persona ( [1981] 1994, 259). El teórico de la moda Frédéric Monneyron sostiene, en este mismo sentido, que el "dimorfismo sexual de la ropa define (...) la identidad masculina y la identidad femenina" ([2005] 2006, 24). Flügel, por su parte, indica que "no es sorprendente que las diferencias entre los sexos encontraran expresión en distinciones de hábito y convención con respecto al vestido (...) tanto entre los salvajes como en los pueblos civilizados" ([1930] 1964 131). En una palabra, la moda aparece en la bibliografía especializada como un elemento que se limita a constatar la "verdad" generizada del cuerpo. El cuerpo desnudo encuentra en la dicotomía sexual, de este modo, el elemento probatorio de su estatuto natural. Pero por otra parte, esa verdad del cuerpo desnudo se proyecta en el cuerpo vestido, creándose así una suerte de acto reflejo teórico que consiste en pensar el cuerpo de la moda como un cuerpo sexuado.

No obstante, partiendo de algunos de los estudios feministas que, desde El segundo sexo de Simón de Beauvoir en adelante, se han encargado de complejizar la relación entre las diferencias sexuales y las instituciones sociales, cabe establecer otro tipo de vínculo entre la moda y los géneros. ${ }^{17}$ Elaboraciones feministas recientes como las de Luce Irigaray y Judith Butler, por ejemplo, señalan que inclusive el sexo, entendido como condición

\footnotetext{
${ }^{17}$ Sobre los distintos derroteros seguidos por el feminismo a partir de las tesis de Beauvoir, véase Simone de Beauvoir, las encrucijadas del otro sexo (Cagnolati y Femenías, 2010).
} 
biológica -y no ya únicamente el género, entendido como constructo cultural seguido en mayor o menor medida del sexo biológico-, es posible toda vez que existe un régimen discursivo que lo enuncia. ${ }^{18}$ En esta medida, según algunas teorías feministas, la diferencia sexual aparece como resultado de un conjunto de procedimientos discursivos e institucionales que la instituyen y soportan. Tanto Irigaray como Butler, por mencionar únicamente dos autoras, ponen en entredicho (tomando a de Beauvoir como su referente polémico), así, la tesis de que la diferencia sexual precede el género. ${ }^{19}$

Para Irigaray, la diferencia sexual surge de una discursividad masculina (a juicio de la autora la única existente a lo largo de la historia) que produce lo femenino como diferencia y que en ese mismo movimiento lo invisibiliza. La diferencia sexual es para Irigaray, en esta medida, "tributaria de una problemática de lo mismo" (Irigaray, [1974] 1978, 25), al tiempo que "la mismidad" está signada por lo masculino. El sujeto, en su opinión, se define a partir de una exclusión constitutiva de lo femenino, y la gramática y la ontología mismas están construidas en función de esa exclusión. Según la autora, la oposición masculino/femenino supone que hay dos términos sustantivos y representables, cuando en realidad toda la economía del discurso se funda sobre la negación de lo femenino. Justamente ese discurso falogocéntrico es el que organiza la materialidad del cuerpo. El objetivo de Irigaray, tal y como lo advierte Femenías, es, en esta medida, "rechazar el dimorfismo sexual como principio de inteligibilidad de la cultura occidental" (Femenías, 2012, 96). En sus críticas al psicoanálisis, Irigaray muestra -como lo he intentado plasmar ya en el capítulo anterior- el modo en que toda la trama semántica con que Freud organiza la corporalidad preedípica viene dada por una ontología falogocéntrica anterior a los cuerpos propiamente dichos: así, según Freud, la niña sufre la falta del falo (y por lo tanto posee una libido carencial) aún cuando tiene un clítoris. En esta medida, todas las supuestas verdades del cuerpo que parten de la dicotomía sexual falogocéntrica, en realidad reafirman y consolidan una comprensión de la anatomía

\footnotetext{
18 Desde un ámbito propiamente histórico, Thomas Laqueur ha mostrado asimismo la viabilidad de entender el género como una construcción anterior al sexo; véase Laqueur ([1990] 1994, 27).

${ }^{19}$ Sobre la centralidad que ocupa el pensamiento de Simone de Beauvoir en el contexto de este debate véase Sexo y género en El segundo sexo de Simone de Beauvoir (Butler, [1986] 1998).
} 
femenina como una anatomía carencial. ${ }^{20}$

Apoyada en estas tesis de Irigaray (aunque también en Nietzsche, Foucault y Wittig), Butler, por su parte, se propone llevar a cabo una genealogía política de las ontologías de género (Butler, [1993] 2008, 53). Dicha genealogía pretende develar el carácter accidental de la oposición metafísica interioridad/exterioridad y lleva a Butler a concluir que "el cuerpo no es un 'ser' sino un límite variable, una superficie cuya permeabilidad está políticamente regulada, una práctica significante dentro de un campo cultural en el que hay una jerarquía de géneros" (Butler, [1993] 2008, 271). El cuerpo, desprovisto así de toda esencia, se convierte en una construcción que se prolonga a lo largo del tiempo bajo la forma de una actuación performativa (a propósito del concepto de performatividad véanse las observaciones del capítulo anterior). Si bien es cierto la performatividad, tal y como la conceptualizara inicialmente Austin, designaba fundamentalmente un procedimiento de carácter lingüístico, para Butler, el performativo se despliega también corporalmente, razón por la cual cabe sostener que las esencias corporales dependen del acatamiento continuado de las normas de género. En esta medida, Butler prefiere hablar de "identificaciones con un género" antes que de "identidades de género". Para Butler, en efecto, "la identidad es un ideal normativo más que un aspecto descriptivo de la experiencia", mientras que la identificación alude a un compromiso del sujeto con una norma que lo habilita pero que no necesariamente le fija una identidad sustancializada (Butler, [1993] 2008, 71). La preeminencia del concepto de identificación por sobre el de identidad subraya, entonces, el carácter socialmente construido de la subjetividad así como la naturaleza provisoria de toda identificación. De este modo, la autora evidencia el carácter ontológicamente inestable (es decir, no fundacional) del sexo y muestra el modo en que las identificaciones generizadas intentan consolidarse en virtud de una serie de actos que afirman basarse en una verdad del cuerpo, pero que en realidad producen dicha verdad performativamente.

A partir de esta perspectiva, las supuestas verdades que habitan los cuerpos (entre ellas, y

\footnotetext{
${ }^{20}$ Para una completa síntesis de los aportes irigarianos al feminismo y a la reflexión a propósito de la diferencia sexual, véase Sobre sujeto y género: re-lecturas feministas desde Beauvoir a Butler (Femenías, 2012, 94-110).
} 
con un protagonismo especial, el género) pueden considerarse más bien producidas y contingentes. La regulación política de los cuerpos, con todo y los efectos de naturalización que dicha regulación requiere, se revela entonces dependiente de una serie de dispositivos que establecen normas somáticas.

En Vigilar y castigar ([1975] 2008) Foucault señala que el prisionero de la cárcel decimonónica era compelido a significar con su cuerpo las normas a través de una serie de dispositivos disciplinarios. Para Butler, en el caso del género, también son necesarias un conjunto de técnicas que permiten al cuerpo significar la verdad de los sexos. En este sentido, como lo indica Femenías comentando a la filósofa estadounidense, la performatividad consiste en una "producción ritualizada (...) una reiteración ritual bajo y mediante ciertas condiciones de prohibición y de tabú, que nunca determinan al sujeto por completo" (Femenías, 2003, 115). Así, dentro de la filosofía de Butler el género, en tanto verdad del cuerpo, nunca se consolida de forma completa. De ahí que para esta autora "la base de la identidad de género es la reiteración estilizada de actos a través del tiempo y no una identidad supuestamente inconsútil” (Butler, [1993] 2008, 274).

Siguiendo a las autoras aludidas, considero que si el género, en tanto supuesta verdad primigenia del cuerpo, no llega a consolidarse por completo (y la obsesividad con que los médicos intervienen los cuerpos para hacerlos entrar dentro de la grilla de inteligibilidad anatomobiológica pareciera confirmarlo) ${ }^{21}$ su hegemonía como norma cultural depende directamente de una serie de técnicas que permiten su actualización. En este sentido, considero que el vestido puede ser examinado como uno de los dispositivo dedicados a disciplinar los géneros. Mi tesis en este sentido es que la moda, lejos de limitarse a representar la diferencia sexual, es uno de los dispositivos que contribuye a su instauración y reproducción performativas. A través de la implementación de marcas sígnicas socialmente establecidas, la moda coadyuva a producir el binarismo sexual, imprimiendo en los cuerpos las señales dicotómicas correspondientes y disciplinando sus gestos y maneras. Los actos, gestos y realizaciones son performativos, en opinión de

${ }^{21}$ Véase al respecto de este empecinamiento médico Butler ([2004] 2006, 89-112) y Preciado ([2000] 2011, 19). 
Butler, cuando la esencia que buscan afianzar es en realidad resultado de fabricaciones discursivas. Mi opinión, siguiendo esta línea, es que el vestido es uno de esos medios discursivos que posibilita la fabricación y preservación del género, aún cuando se suela suponer que este último es más bien anterior a las en/vestidas de la moda.

Así, la moda establece marcas a partir de las cuales los cuerpos se identifican con un género, pero, mediante un retruécano discursivo, el género se plantea como anterior a la adopción de dichas marcas. La realidad, sin embargo, es que no es posible identificarse con un género sin un compromiso sostenido con los códigos vestimentarios que cada época establece -pese a que ciertamente cada período histórico varíe dichos códigos-. Esto no quiere decir que el género se haga únicamente mediante las prendas, sino que la moda constituye un dispositivo material de gobierno que históricamente ha revelado una particular eficacia a la hora de llevar a cabo dicha producción performativa. En esta medida, aún cuando la historia del vestido da cuenta del hecho de que en las distintas épocas históricas el tipo de disciplinamiento que la moda ejerce en tanto dispositivo generizador varía (en virtud del hecho de que las construcciones de género también lo hacen), lo cierto es que dicha historia también muestra la constancia con que los vestidos han contribuido a producir, acentuar y mantener las diferencias sexuales. La moda, por lo tanto, constituye una instancia de subjetivación que, al tiempo que faculta a los cuerpos para identificarse con un género, plantea paradójicamente al género como institución necesaria y previa a toda identidad. En otras palabras, mi tesis en este sentido es que el género funge como el principal enclave ontológico a partir del cual se despliegan mecanismos de control sobre el cuerpo vestido.

En esta medida, me parece que cabe hablar de la moda como un mecanismo de disciplinamiento del género. En lugar de partir del cuerpo sexuado como supuesto, desde esta perspectiva, la "verdad" generizada del cuerpo debe examinarse a la luz de sus efectos. De este modo, en torno al vestido no se jugaría solamente una simple propagación de tendencias o de preferencias estéticas, sino la modelación performativa del cuerpo. A partir de este enfoque, en suma, el género se presenta no ya como una "verdad" del organismo, sino como un elemento a partir del cual se fundamentan una 
serie de procedimientos - en cuenta los relacionados con la moda- que disciplinan los cuerpos. En los apartados siguientes de este capítulo me dedicaré, precisamente, a analizar la manera en que se echan a andar dichos procedimientos disciplinarios.

\subsection{Las disciplinas allende la cárcel decimonónica: hacia un análisis de la moda como dispositivo disciplinario}

Según el modelo aplicado por Foucault para estudiar la cárcel decimonónica europea, el poder disciplinario dota al cuerpo de una determinada morfología. El propósito, en el caso de la disciplina carcelaria analizada por Foucault, es producir anatomías dóciles pero que simultáneamente, a través del trabajo, resulten productivas. De la mano de los poderes disciplinarios la prisión moderna instituye, así, una forma particular de ejercer la vigilancia y el castigo.

Sin embargo, el propio Foucault admite que las disciplinas desbordan el ámbito penitenciario. Foucault define las disciplinas, en efecto, como conjuntos de "métodos que permiten el control minucioso de las operaciones del cuerpo, que garantizan la sujeción constante de sus fuerzas y les imponen una relación de docilidad-utilidad" ([1975] 2008, 159), y encuentra en la escuela, el manicomio y el ejército, ejemplos de instituciones en las que se despliegan dichos métodos. Por otra parte, si bien el filósofo francés sitúa el epicentro histórico/geográfico del poder disciplinario en las sociedades europeas de los siglos XVIII y XIX, también considera que los mecanismos disciplinarios "vienen de lejos" ([1975] 2008, 81) e indica, asimismo, que "en nuestra [propia] sociedad existe algo que podríamos llamar poder disciplinario" ([2003] 2008, 59). Por tanto, cabe pensar en lo mecanismos disciplinarios como métodos de control corporal que desbordan la cárcel decimonónica y que se despliegan en otros ámbitos culturales e históricos. La moda, en mi opinión, es de hecho uno de esos ámbitos.

El poder disciplinario se caracteriza en un sentido general por establecer una relación entre el aumento de aptitudes y el acrecentamiento de la dominación. El principio de esta 
forma de control es que cuanto más disciplinado está un cuerpo, tanto más apto resulta para los regímenes de poder que pretenden controlarlo. De ahí que el poder disciplinario sea conceptualizable como un poder capaz de fijar ideales y categorizar individuos a partir de los mismos. El poder disciplinario funciona, así, estableciendo dispositivos de asimilación de lo anormal en múltiples campos y creando mecanismos de afirmación de las normas incluso a partir de los sujetos que quedan por fuera de ellas (volveré sobre el asunto de la normalidad más adelante en este mismo capítulo). Asimismo, el poder disciplinario se caracteriza por una vigilancia sostenida y continua del cuerpo y sus movimientos, así como por una atención a su gestualidad y a su postura. ${ }^{22}$

Todas estas características se cumplen, como lo señalaba anteriormente, en el caso de la moda. No obstante, hablar de la moda como práctica disciplinaria suscita una serie de interrogantes: ¿en qué sentido se puede decir que la moda sujeta al cuerpo?, ¿impone la moda un control sobre los movimientos?, ¿qué aptitudes podrían corresponderle a los cuerpos fabricados por la moda?

Algunos ejemplos históricos pueden arrojar luz sobre estas cuestiones. La historia del vestido es, en efecto, rica en ejemplos que dan cuenta de ese carácter disciplinario de la moda, y en los apartados siguientes, de hecho, me dedicaré a analizar algunos de ellos. Desde vestidos con tintes abiertamente ortopédicos, hasta los distintos casos de sanciones para lo démodé, pasando por prendas altamente compresoras y debilitadoras, o bien por aquellas que encausan y dirigen movimientos, un verdadero stock de dispositivos disciplinarios puebla, ciertamente, la historia de la moda. Sin embargo, antes de entrar de lleno en los ejemplos que deseo analizar, quisiera detenerme a explicar el modo en que podría conceptualizarse la prenda como un elemento disciplinario.

El propio Foucault habla de elementos materiales que se funden con el cuerpo a la manera de artilugios disciplinadores. En su seminario de 1973 en el Collège de France titulado El poder psiquiátrico, el teórico francés se refiere, en efecto, a aparatos

\footnotetext{
${ }^{22}$ Para una caracterización detallada del poder disciplinario véase Vigilar y castigar ([1975] 2008, 157261) así como la clase del 21 de noviembre del curso El poder psiquiátrico, dictado por Foucault en el Collège de France en 1973 (2008, 57-80).
} 
corporales destinados a la "corrección morfológica". Según Foucault, este tipo de aparatos corporales pueden dividirse en cuatro: los aparatos de garantía y prueba -se trata de dispositivos como el cinturón de castidad, a partir de cuya utilización cierto tipo de acciones quedan vetadas en una suerte de desafío de autodominio que el dispositivo plantea al sujeto sobre el cual se aplica-, los aparatos para arrancar la verdad -es decir, los instrumentos utilizados para la tortura-, los aparatos de marcación -cuya función consiste en sellar el cuerpo con la fuerza del poder-y los aparatos ortopédicos -cuyo objetivo es el enderezamiento del cuerpo- (Foucault, [2003] 2008, 130-131). Con excepción del segundo tipo de aparato corrector, la moda cuenta, de hecho, con aparatos disciplinarios de los restantes tres tipos: prendas que proscriben movimientos con el fin de mostrar que se es capaz de dominar los propios deseos (piénsese en las ceñidos vestidos que requieren de todo un régimen de alimentación para poder ser portados), tendencias vestimentarias exclusivas para cierto tipo de personas (como las dirigidas según el género, la edad, o el rango) y dispositivos vestimentarios dirigidos a adiestrar el cuerpo (como ocurre por ejemplo en el caso del corsé) muestran, en efecto, que la moda posee una manifiesta proclividad a disciplinar el cuerpo. En otras palabras, diversas prendas califican como aparatos correctores en el sentido de que se emplean a fin de controlar las siluetas y el espesor de los cuerpos. Los dispositivos correctores, tal y como los define George Vigarello a partir de Foucault, designan, en efecto, todos aquellos artilugios (entre los cuales, por cierto, Vigarello incluye los vestidos) dirigidos a disciplinar los cuerpos imponiéndoles la forma que, según el régimen de verdad en boga, se considera natural (Vigarello, [2001] 2005, 19-27). La utilización del adjetivo "corrector", por tanto, alude a un empleo de la prenda que se lleva a cabo so pretexto de devolverle al cuerpo una forma que se le supone consustancial. No obstante, según Vigarello, los mecanismos correctores hacen el cuerpo y esta es precisamente la medida de su vocación disciplinaria: afirman corregir, cuando en verdad, son productivos (es decir que los cuerpos siempre adquieren sus formas y contornos sobre la base de un trasfondo normativo, sea que este se acepte o se rechace).

Volviendo a Foucault, es preciso señalar que los dispositivos correctores poseen, además, unas determinadas características. Para Foucault, en efecto, los aparatos corporales 
destinados a la corrección disciplinaria poseen básicamente tres rasgos: son homeostáticos -en virtud del hecho de que cuanto menos resistencia se les opone menos se los siente-, de acción continua -en la medida en que su eficacia se extiende allende su uso- y de efecto progresivo -dado que cuanto más se lo emplea mejores efectos ortopédicos ofrece- (Foucault, [2003] 2008, 131). Aplicando este modelo al campo del vestido resulta que efectivamente los dispositivos vestimentarios son homeostáticos por cuanto las incomodidades que puedan suscitar algunas prendas son tanto menos incómodas cuanto menos resistencia se le oponga a la morfología que estas buscan imponer, de acción continua puesto que las modas impactan las morfologías sin necesidad de que el usuario tenga puesta la prenda permanentemente, y de efecto progresivo por cuanto se espera que la prenda termine por imponer al cuerpo una actitud, de forma tal que una determinada gestualidad quede impresa en la anatomía de los sujetos aún cuando estos prescindan del dispositivo corrector en cuestión

A partir de este punto de mira foucaultiano procederé entonces a analizar algunas de las técnicas correctivas que han tenido lugar en la historia de la moda de la mano de ciertas prendas. Fundamentalmente, lo que me interesa mostrar es la tendencia de la moda a fijar en el cuerpo unos contornos y unas gestualidades específicas según los géneros. Específicamente, me detendré a reseñar, a manera de ejemplos, el uso disciplinante de tres prendas: el corsé, la crinolina y la peluca. Se trata de dispositivos correctores que intentan producir un tipo de corporalidad acorde con los ideales somáticos de cada época. Mi objetivo, así, es mostrar que la moda, pese a su carácter aparentemente frívolo y superficial, posee una dimensión disciplinaria con consecuencias sociales y políticas de peso, aún cuando dicha dimensión haya sido hasta cierto punto menospreciada por los estudiosos del vestido.

\subsection{El emblemático caso del corsé}

El corsé se erige en la historia de los dispositivos correctores como un ejemplo privilegiado por las evidencias que suscita y por lo hiperbólico de las presiones que 
ejerce. Sin embargo, existen datos sobre utilizaciones disciplinarias de las prendas mucho anteriores. La prehistoriadora española Almudena Hernando, por ejemplo, señala que ya en la Edad de Bronce -esto es, hacia 1500 años a.c- existían adornos que, como las abrazaderas de bronce -las cuales unían las pantorrillas mediante cadenas- limitaban "la movilidad de las mujeres, provocando una manera de andar y de moverse" (Hernando, $21012,125)$. Sin embargo, este tipo de dispositivos, debido a su lejana procedencia histórica, resultan bastante más difíciles de datar. El corsé, en cambio, no solo constituye una moda que se prolongó a lo largo del tiempo, sino que también se trata de una prenda que extendió sus dominios por múltiples regiones.

Los corsés aparecen durante el siglo XVI en Europa pero atraviesan con altos y bajos los siglos XVII, XVIII y XIX, llegando incluso al siglo XX. En el caso latinoamericano, el corsé también logra imponerse, aunque de una forma más bien de tardía, en el siglo XIX. En Argentina, por ejemplo, no se populariza su uso sino hasta 1830, extendiéndose el mismo, sin embargo, hasta finales del siglo XIX e inicios del XX (Saulquin, 2008, 53).

El carácter abiertamente ortopédico del corsé durante el siglo XVI es destacado por los historiadores, quienes señalan que sus primeras utilizaciones en niños obedecían a recomendaciones médicas que ensalzaban sus cualidades correctoras (Vigarello, [2001] 2005, 15-16). En ese sentido, no es casualidad que la puesta en boga del corsé a mediados del siglo XVII en Europa coincida con la invención del aparato de Fabrice d' Aquapendente: una máquina enderezadora construida con acero y cremalleras (a medio camino entre la prenda y el aparato médico) que corregía las patologías corporales (Vigarello, [2004] 2009, 80). Este tipo de aparatos correctores estético/médicos, los cuales, por cierto, llegarán inclusive hasta nuestros días por intermedio de diversas prácticas que participan tanto del registro estético como del médico -piénsese por ejemplo en la ortodoncia, la cual manipula la estructura dentomaxilofacial en aras de que esta adquiera una constitución que se considera simultáneamente más hermosa, higiénica, armoniosa y saludable (Calderón, 2004, 10)- se divulgarán paulatinamente cada vez más a través del campo de la moda. 
Inicialmente utilizado en niños de ambos sexos, el empleo del corsé se complementaba con una serie de lecciones de urbanidad y decoro. El disciplinamiento del cuerpo del infante, que durante esta época consistía exclusivamente en fijar una postura, se preocupa ante todo por el enderezamiento y el moldeado a través del masaje y la compresión. Una analogía es particularmente explícita al respecto: el cuerpo del niño se asimila a un árbol que, si no es vigilado durante su crecimiento, se curva y adquiere contornos anárquicos (Vigarello, [2001] 2005, 16). Estas estrategias de control corporal que, como lo muestra Vigarello todavía no se interesaban por inducir movimientos sino únicamente posturas, veían en el cuerpo del niño una superficie pasiva acorde con la imagen general que la época poseía de la infancia como etapa de dependencia y quietud receptora.

Más adelante, sin embargo, los corsés tendrán por objeto también el disciplinamiento del movimiento femenino. ${ }^{23}$ Una vez relevadas sus funciones exclusivamente sanitarias, en efecto, el corsé pasa a ser un dispositivo dirigido fundamentalmente a las mujeres. Con este cambio de usuario, el corsé no varía únicamente su coartada (pues en efecto esta varía: los corsés dejan de utilizarse por recomendación médica y comienzan a emplearse por razones de índole estética), sino que también su objetivo a nivel disciplinario mutará: en adelante su norte será el control del movimiento de las mujeres.

Esta tendencia llega a su apogeo hacia mitades del siglo XIX. Durante esta época, el corsé se conjugó con otras prácticas de moda que redundaron en una inmovilidad casi absoluta de las mujeres. Las mujeres de dicho período no solo llevaron más ropa que las de cualquier otro período de la historia -según James Laver en 1850 las mujeres llevaban 10 veces más ropa que en 1800 (Laver, [1982] 2008, 157)-, sino que además implementaron cosméticos y otras técnicas de embellecimiento, como por ejemplo el consumo de vinagre en aras de empalidecer el rostro, que confirman los cánones de una época que se empeñaba, corsé de por medio, en ver en las mujeres seres enfermizos y débiles (Laver, [1982] 2008, 172). En este contexto, el corsé no solo comprimirá el cuerpo femenino sino que se convertirá en la prenda por excelencia de la mujer a la

\footnotetext{
${ }^{23}$ Sobre la importancia de la vestimenta como recurso de control simultáneo de los niños y las mujeres durante el siglo XVI véanse las observaciones de la feminista canadiense Shulamith Firestone ([1973] 1976, 98-132).
} 
moda; una mujer cuyos reducidos movimientos y gestos quedarán sigilosamente diagramados y observados.

En efecto, contrariamente a los corsés del siglo XVI, los de los siglos XVII, XVIII y XIX no se limitaban a fijar una gramática corporal, sino que también estaban diseñados para incitar actividades y aptitudes. De este modo, el ideal de la delicadeza y la fragilidad tomaban por asalto el cuerpo por una vía -el corsé- que no solo resultaba efectiva sino que además gozaba de popularidad. Hacia 1845, la apariencia de las mujeres incluía una serie de modos que evocaban desamparo y dependencia. En una atípica contradicción con los discursos provenientes del ámbito de la salud, la moda de esa época concitaba gestos y desplazamientos que debían irradiar sufrimiento y debilidad; incluso enfermedad. En este sentido, el corsé tuvo un papel fundamental, pues impuso una serie de aptitudes y actitudes a los cuerpos femeninos.

Una gestualidad ampliamente codificada quedaba, así, articulada en los cuerpos de las mujeres fundamentalmente a través de una prenda. El corsé, en tal sentido, es quizá una suerte de hito en lo referido al carácter disciplinario de la moda. Pero, como mostraré a continuación, se trata solo de un ejemplo entre varios posibles.

\subsection{La estrategia de la visibilización permanente: la crinolina y el control de las interacciones}

El corsé, en efecto, no es el único traje que da cuenta del carácter disciplinario de la moda. La crinolina, prenda surgida en el siglo XVIII pero que no logra imponerse como moda hasta el siglo XIX, constituye otro buen ejemplo de un dispositivo vestimentario destinado a disciplinar los cuerpos de las mujeres.

Surgida como resultado de un ensanchamiento progresivo en el ancho de las faldas, la crinolina aparece como solución a la enorme cantidad de ropa interior necesaria para generar el efecto de amplitud prescrito por la moda de la época. La crinolina consistía en 
una especie de jaula de madera que salía de la cintura y que llegaba casi hasta el suelo a través de unos aros concéntricos cosidos a la falda, los cuales daban a esta una forma de campana. La crinolina, que en principio parecía favorecer el movimiento (puesto que no solo eliminó el peso de la gran cantidad de enaguas que se estilaba usar para poder ensanchar las faldas, sino que también dio un rango de acción a las piernas antes inimaginable) se convirtió, sin embargo, en una manera de controlar desplazamientos y posturas, así como de manejar las actividades y el empleo del tiempo de las mujeres.

Mientras que el miriñaque (artefacto antecesor de la crinolina, construido con mimbre y utilizado a lo largo del siglo XVIII) ya dificultaba que dos mujeres pasaran simultáneamente por una puerta o compartieran el asiento de un carruaje, la vocación descaradamente disciplinaria de la crinolina la lleva a adquirir un volumen tal que "a dos mujeres les era imposibles entrar juntas en una habitación o sentarse en el mismo sofá porque los volantes de una ocupaban todo el espacio" (Laver, [1982], 2008, 181). Esta estrategia de visibilización permanente -según Laver las crinolinas llegaron a alcanzar incluso los 4 metros y medio (Laver, [1982], 2008, 132-133)- no solo distribuía los cuerpos dentro del espacio asignándoles un lugar, sino que garantizaba su disponibilidad a la mirada.

Por otra parte, la crinolina trajo consigo la agresiva cultura de la "caída galante". Atrapadas las mujeres dentro de las rígidas estructuras de madera y con menos ropa interior que antes, sus caídas al suelo comenzaron a ser fuente de atracción erótica para los varones (Gavarrón, 1997, 105). En una palabra, la dificultad en el movimiento y la congoja femeninas eran erotizadas por el efecto de una mirada masculina que encontraba atractivos los cuerpos de las mujeres cuanto más compelidos estuvieran al tropiezo y la falta de flexibilidad (otro tanto ocurre hoy día, por cierto, con modas como la de los zapatos de tacón alto).

La atención a las confluencias y la preocupación por la proximidad y las excesivas complicidades es, por otra parte, solidaria de la restructuración de otros espacios sociales donde también se comenzaba a distribuir los cuerpos con meticulosidad: hospitales, 
cárceles y fábricas, por citar algunos ejemplos. La filósofa y activista francesa Simone Weil -quien dicho sea de paso adelantó una buena parte de las intuiciones foucaultianas sobre la naturaleza del poder disciplinario- señala al respecto cómo en el caso de la fábrica - uno de los espacios disciplinarios por excelencia- la estrategia para evitar el intercambio y la conversación entre las mujeres consistía en la imposición de un ritmo: "para 'llegar' [señala Weil] hay que repetir movimiento tras movimiento con una cadencia que, al ser más rápida que el pensamiento, prohíbe dar curso libre no sólo al pensamiento, sino incluso a los sueños" (Weil, [1951] 2010, 52). La fábrica y la moda constituyen, en tal sentido, dos dispositivos disciplinarios que, no obstante sus diferentes métodos de disciplinamiento, comparten su móvil histórico: controlar el empleo del tiempo y el movimiento a fin de controlar los vínculos entre las mujeres.

Se trata de una estrategia que recuerda las técnicas de "división por zonas" y de "emplazamiento funcional" descritas por Foucault en Vigilar y castigar: el espacio disciplinado establece presencias e induce o interrumpe comunicaciones según su conveniencia; además, ubica los cuerpos donde estos resultan más provechosos (Foucault, [1975] 2008, 166-167). Al igual que el cuerpo del prisionero los cuerpos diseñados por la crinolina eran administrados para que guardaran distancias y para que sus movimientos pudieran ser objeto de vigilancia permanente. En otras palabras, la crinolina surge como un artefacto que ofrece unos réditos significativos en términos de un control social de las mujeres. Mientras el corsé se utilizaba para controlar posturas y movimientos, la crinolina aparece como un dispositivo cuyo énfasis principal consiste en conferir al cuerpo femenino unas formas más fácilmente vigilables.

No obstante, las prendas un poco aparatosas al estilo del corsé y la crinolina no son las únicas capaces de imprimir formas dóciles al cuerpo. Como veremos, dispositivos aparentemente sutiles como la peluca, también son capaces de suscitar potentes reestructuraciones morfológicas y de imprimir maneras dóciles al cuerpo. 


\subsection{La peluca: de la decoración a la inmovilización}

La peluca, en efecto, constituye otro caso de un dispositivo vestimentario utilizado con fines disciplinarios. Los teóricos del vestido - quienes, en conformidad con las líneas de análisis canónicas que describí en el primer capítulo se han limitado, las más de las veces, a ver en el cuido del cabello una práctica cuya lógica viene dada por la pertenencia a una clase- no han reparado, sin embargo, en sus efectos sobre el cuerpo. Squicciarino, por ejemplo, se limita a constatar que "los aspectos particulares de la personalidad del individuo [como] su clase social (...) se pueden señalar visualmente a los demás a través del peinado" ([1986] 1998, 66). Sin embargo, como mostraré a continuación, alrededor del cuido del cabello también han tenido lugar una serie de técnicas de vigilancia y de castigo similares a las de las modas recién descritas.

Las pelucas, de las cuales hay noticia ya en las civilizaciones antiguas, tienen su apogeo en el siglo XVII, y a inicios del XVIII se convierten en auténticos dispositivos de control corporal. Si bien su uso en la Antigüedad por los egipcios y romanos poseía ya tintes disciplinarios al producir aspectos diferenciales entre varones y mujeres y al clasificar con base en su apariencia a las mujeres casadas de las solteras (Sauvageot y Menard, 2007, 91-111), su implementación moderna producirá aún más réditos en términos de control social.

Durante el siglo XVIII, en efecto, mientras que las pelucas masculinas -las cuales se limitaban a un conjunto de numerosos rizos que llegaban por debajo de los hombrosfueron objeto de una rápida simplificación, las pelucas de las mujeres, por el contrario, llegaron a un grado de complejidad cada vez mayor. Esa divergencia en los destinos de ambas pelucas se explica en virtud de dos factores interrelacionados: por un lado, el afán de proveer cierto rango de movimiento corporal a los varones y, por otro, el afán de fijar los cuerpos femeninos de modo que estos quedaran disponibles para la mirada masculina. En otras palabras, las pelucas funcionaban a la manera de dispositivos productores ya fuere de masculinidad, o de feminidad. En el caso masculino, el motivo histórico del 
cambio a una peluca más simple se da con base en argumentos militares: la incomodidad producida por la prenda dificulta al soldado llevar a cabo los movimientos que debe realizar. La peluca in-folio (esa que figura en los retratos de los filósofos de la época) es, de hecho, remplazada por la peluca “de campaña”, la cual reducía los rizos a tres mechones que se estilaba sujetar mediante un lazo en la parte superior de la cabeza (Laver, [1982], 2008, 130).

Mientras que la peluca, en tanto dispositivo disciplinario, se distendía en relación con los cuerpos masculinos (los cuales, en todo caso, eran "fabricados", a través del disciplinamiento militar), en el caso de las mujeres se convirtió en un modo de control técnico de la cabeza. En un caso, el de los soldados, se presumía que la cabeza debía estar relativamente descubierta en aras de alcanzar un estado de alerta que les permitiera reaccionar con velocidad en la batalla, razón por la cual debían evitarse las pelucas demasiado grandes o pesadas. En el caso de las mujeres, por el contrario, las pelucas alcanzaron volúmenes exagerados, en virtud de un afán masculino de inmovilización del cuerpo femenino. La diferencia sexual se desplegaba entonces, peluca de por medio, asignando performativamente una cualidades a los cuerpos.

Según Laver, en la segunda mitad del siglo XVIII, algunos peinados femeninos llegaron a medir cerca de un metro ([1982] 2008, 142), de forma tal que el conjunto de los cuerpos de las mujeres parecieran haber estado ataviados en función de mostrar las monumentales pelucas que dictaba la moda. De este modo, las mismas partes del cuerpo que en los varones eran herramientas para la guerra (ojos, orejas, etc.), constituían, en el caso femenino, elementos decorativos de inmensas pelucas con los más extravagantes motivos: "un barco con las velas desplegadas, un molino de viento con animales de granja alrededor, un jardín con flores naturales o artificiales” (Laver, [1982], 2008, 143).

Estos elementos decorativos incidían dramáticamente en el equilibrio corporal de las mujeres, modificando su centro de gravedad y alterando su manera de andar (justo como sucederá más adelante con las plataformas en el calzado), pero por otra parte, para decorar semejantes artilugios, las mujeres debían poner en sus cabezas diversos 
materiales y objetos como cojines rellenos de lana o crin de caballo, alambre, sombreros, pomadas y polvos blancos. Como era de esperarse, estos peinados se convertían en el hábitat ideal para la proliferación de parásitos y generaban escozor y dolor en la cabeza. Ocupadas en montar y fijar estas complejas estructuras, así como en agenciárselas para reducir el picor, las mujeres se veían compelidas por la moda a limitar sus cabezas a objetos para la contemplación.

En correspondencia con el principio de que "en la disciplina son los sometidos los que tienen que ser vistos" (Foucault, [1975] 2008, 218), las pelucas femeninas del siglo XVIII establecían una economía de la visibilidad en la que el poder no solo se ejercía convirtiendo la cabeza en un objeto para la contemplación, sino también asignando a sus órganos una función estética y desproveyéndolos de sus otras cualidades. En esta medida, me parece manifiesto que, lejos de agotarse en una simple demostración de prestigio, la utilización de las pelucas durante el siglo XVIII contiene una dimensión disciplinaria, al igual que ocurre en el caso de los dispositivos anteriormente examinados.

\subsection{Moda y normalización}

Los ejemplos anteriores, aún cuando se refieren a épocas, contextos geográficos y prendas específicos pretenden poner en evidencia la viabilidad de un análisis de la moda como forma de disciplinamiento corporal. Desde esta perspectiva teórica, la moda contribuye a hacer performativamente el cuerpo, asignándole siluetas y dotándolo de una subjetividad generizada. Pero siendo que las disciplinas se caracterizan por un modo de castigar muy específico, cabe preguntarnos ahora por las modalidades de castigo que la moda, en tanto ejercicio de disciplinamiento, involucra. Si las prendas, tal y como acabo de mostrar, son empleables a la manera de dispositivos correctores, surge, en efecto, la pregunta de dónde obtiene la moda su capacidad "disuasoria".

Mientras que las disciplinas propias del manicomio y del ámbito carcelario obtienen su eficacia, tal y como lo indica Foucault, a partir del encierro, la moda, en cambio, apela a 
la seducción de los usuarios de vestidos sin apelar a la coerción física. Modelos como el de la imitación o el de la difusión viral no permiten, por otra parte, explicar dichas formas de seducción en la medida en que consideran que los mecanismos difusores de la moda vienen dados por la naturaleza antropológica del ser humano (véase capítulo 1). En tal sentido, los estudios clásicos priorizan al asunto de la difusión por sobre el problema de la normalización y dejan de lado, así, la manera en que la moda opera como un sutil mecanismo de poder.

Si se considera la moda como un mecanismo disciplinario se hace necesario, por el contrario, poner el acento en los procedimientos mediante los cuales los dispositivos vestimentarios obtienen legitimidad. Contrariamente a los castigos propios de otras formas de poder, las disciplinas, en efecto, corrigen a partir de la instauración de regímenes de normalización. La normalización, tal y como la define Foucault, designa un poder "positivo, un poder que fabrica, que observa, un poder que sabe y multiplica a partir de sus propios efectos" ([1999] 2003, 55). Mientras que dentro de otros regímenes de poder no disciplinarios el castigo se ejerce fundamentalmente a través de la penalización represiva, las disciplinas por su parte, castigan, de una forma productiva mediante la sanción normalizadora. En otras palabras, el poder disciplinario tiene una especial tendencia a funcionar no solo inhibiendo comportamientos, siluetas o morfologías, sino también induciéndolas mediante mecanismos normalizadores. La norma, en tal sentido, opera como ideal orientador de los procesos de disciplinamiento. $\mathrm{Si}$ las disciplinas constituyen técnicas de poder dirigidas a la gestión del cuerpo de los individuos, las normas pueden entenderse, por lo tanto, como los ideales a partir de los cuales se justifican los procedimientos disciplinadores. La moda, en tal sentido, encuentra en las distintas formas de normalización sus recursos punitivos. La pregunta desde una lectura genealógica, por ende, no es tanto cómo se difunden las modas, sino de qué modo obtiene la moda su eficacia normativa.

Foucault define la norma como un tipo de reglamentación distinta -aunque no necesariamente opuesta- a la reglamentación impuesta por la ley ([1999] 2002, 45). Para Foucault, mientras la ley constituye un constructo que se limita a trazar una línea 
divisoria entre lo permitido y lo prohibido y a realizar las sanciones correspondientes, la norma funciona de un modo más sutil creando ideales positivos que operan a la manera de paradigmas a los cuales los individuos deben apuntar si quieren devenir sujetos normales. Por supuesto, se trata de formas de poder que no necesariamente actúan por separado. A menudo, de hecho, los procesos de normalización cohíben conductas y expresiones corporales a través de la instauración de otras en su lugar. Por otra parte, las leyes incluyen también paradigmas de subjetividad que, quienes las siguen, a menudo aspiran a cumplir. En todo caso, lo que importa subrayar es el modo en que las normas constituyen no únicamente ideales orientadores, sino también poderosos constructos ontológicos que se inscriben en los cuerpos. En este sentido, se trata de una diferencia de acentos: mientras la ley funciona exclusivamente a la manera de una sanción represiva, la norma, en cambio, funciona también productivamente, conminando a los individuos a transformarse a sí mismos de modo que calcen dentro de los paradigmas establecidos (Foucault, [1999] 2002, 226-227).

Las modas, de esta forma, marcan los cuerpos echando mano de las normas en tanto ideales punitivos que operan de forma positiva. Lo normal funciona, en tal medida, como un conjunto de criterios a partir de los cuales se llevan a cabo estrategias de disciplinamiento sobre los cuerpos en aras de que estos asuman una morfología determinada. El epistemólogo francés George Canguilhem -cuya posición respecto de las normas inspira la de Foucault- señala a este respecto que aún la concepción de normalidad utilizada a lo interno de los discursos científicos apunta señalar precisamente "aquello que es tal y como debe ser" ([1966] 2011, 91). En el caso de la moda ocurre algo similar: la norma constituye un horizonte que moviliza acciones y conductas y que configura cuerpos. Las normas impulsadas por la moda establecen arquetipos corporales que exigen un trabajo de y sobre el organismo. En tanto recursos punitivos, las normas buscan hacer converger la función/sujeto con una determinada morfología corporal, tal y como hemos visto que sucede en el caso de las prendas correctoras antes examinadas. Esta concepción de normalidad requiere de un sujeto anormal asimilable a la normalidad. La anormalidad funciona, en tal medida, como una coartada discursiva que otorga validez y autoridad a las disciplinas, toda vez que reclama el ajuste de los cuerpos a un ideal 
somático. Se trata de una artimaña discursiva que augura la normalidad a unos individuos amenazados con quedar por fuera de la esfera de lo aceptado. Dentro de esta perspectiva, los cuerpos son disciplinados a través de la moda no por efecto de un impulso antropológico que les generaría la necesidad de distinguirse, sino por intermedio de una serie de normas que operan socialmente como medios de punición.

Continuando con mi argumentación anterior quisiera mostrar, así, que el disciplinamiento corporal involucrado en la moda se articula con procesos de normalización. El problema del porqué se instauran normas vestimentarias que a la postre son seguidas por las mayorías, en mi opinión, debe entonces reformularse a partir del problema de la normalización y la capacidad de la moda de establecer sanciones para quienes no se atienen a sus preceptos. La pregunta de los teóricos del vestido respecto de la naturaleza difusora de la moda, pues, debe substituirse, según creo, por la pregunta a propósito de los efectos normalizadores que la moda posee en los cuerpos. A mi criterio, dichos efectos normalizadores de la moda dependen de la creación de ideales de belleza, así como de la instauración de regímenes de administración de los placeres; es decir, de una suerte de economía libidinal. A partir de su relación con los imaginarios sobre la belleza, así como de su vínculo con regímenes de control de la sexualidad, la moda, de hecho, establece sistemas de compensación y de castigo, tornando normales unas ciertas morfologías así como legitimando unos determinados placeres. Por otro lado, esos procesos de normalización, al ir de la mano con el disciplinamiento del género, poseen, tal y como lo advierte Shulamith Firestone, una función política, pues "a medida que las mujeres empiezan a parecerse más y más unas a otras, distinguiéndose tan sólo por el grado de divergencia con respecto a un ideal teórico, pueden ser estereotipadas con creciente facilidad" ([1973] 1976, 192). El disciplinamiento y la normalización vestimentaria operan en este sentido como elementos de control social de los cuerpos sexuados (especialmente de los cuerpos clasificados como femeninos).

Mediante el disciplinamiento del género, así, la moda se impone además como mecanismo de normalización. En consecuencia, analizaré a continuación los que a mi juicio constituyen los dos pilares impulsores de dichos mecanismos de normalización: 
por un lado, los estereotipos de belleza y, por otro, lo que la feminista estadounidense Adrienne Rich ha denominado la heterosexualidad obligatoria.

\subsection{Vestir y castigar: normalización, belleza y heterosexualidad obligatoria}

Desde la perspectiva recién propuesta, el establecimiento de normas corporales se encuentra ligado, por tanto, a ideales históricos de belleza. Como lo indiqué supra, las distintas modas operan a partir de criterios racionales que apelan a la conveniencia estética o funcional de las prendas. De la misma forma, la moda establece sanciones para quienes no se atienen a sus preceptos. En este sentido, la puesta en marcha de una moda viene siempre de la mano con una serie de sanciones normalizadoras para quienes no se atienen a las mismas.

Según Foucault, la sanción normalizadora posee unas características específicas. En primer lugar dichas sanciones involucran el establecimiento de una "infra-penalidad". En otras palabras, en opinión del filósofo las disciplinas incluyen el establecimiento de un sistema de castigo que penaliza todo aquello que queda por fuera de la ley. La norma opera, en tal sentido, a la manera de un corpus autónomo de reglas que define lo punible de forma tal que las más mínimas acciones sean castigables y que los elementos en apariencia más banales posean una función punitiva - se trata de lo que el pensador francés denomina la universalidad castigable-castigante propia de la sanción normalizadora (Foucault, [1975] 2008, 209)-. En segundo lugar, Foucault caracteriza la sanción normalizadora por su afán de castigar la desviación. Esto es: el ámbito de aplicación de las disciplinas es todo lo no-conforme, lo que altera el orden, lo que no corresponde. El enemigo de las disciplinas es, en esta medida, el "desviado" (Foucault, [1975] 2008, 209). En tercer lugar, los procesos de normalización poseen una naturaleza correctiva, no solo en el sentido antes indicado de que adecuan el cuerpo a la norma, sino también en tanto y en cuanto incluyen una dimensión repetitiva que encauza la conducta mediante el ejercitamiento. En este sentido, la normalización adquiere una dimensión propiamente temporal (Foucault, [1975] 2008, 209-210). En cuarto lugar, la sanción 
normalizadora posee, según Foucault, una dinámica de gratificación-sanción, es decir, una tendencia a calificar como debidas o indebidas las conductas y a distribuir a los individuos a partir de las mismas. Por último, para Foucault, la sanción normalizadora es proclive a instaurar sistemas jerárquicos que ordenan, homogenizan y castigan simultáneamente, haciendo del escalafón jerarquizador una forma de castigo en sí mismo y un modo de homologar, diferenciar y vigilar. ${ }^{24}$

Retomando la hipótesis de que la moda posee una dimensión normalizante considero que todas estas características atribuidas por Foucault a la sanción normalizadora se encuentran articuladas en el universo del vestido de la mano de paradigmas epocales de belleza así como de la instauración de la heterosexualidad obligatoria. Antes de analizar el modo concreto en que se despliegan dichas características alrededor del problema del vestido, por lo tanto, creo necesario detenerme a caracterizar el modo en que la moda se liga tanto a los paradigmas epocales de belleza como a la heterosexualidad obligatoria

La belleza, en tanto grilla de inteligibilidad históricamente articulada con la diferencia sexual, permite, en efecto, tal y como lo señalé antes, disciplinar los cuerpos proporcionándoles unas determinadas formas. Mediante su compromiso continuado con los rasgos vestimentarios propios de cada género, los cuerpos, de esta manera, son objeto de procesos de autotransformación que tienen como horizonte disciplinario la adquisición de una serie de rasgos que se consideran bellos. Los ideales de belleza de cada género, en esta medida, tienden a producir, reflejar, implementar y/o complementar las normas corporales que cada época construye. El disciplinamiento del cuerpo que el vestido lleva a cabo se fundamenta, pues, no solo en el binarismo sexual, sino también en una determinada comprensión de lo que constituye un cuerpo bello o atractivo dentro de los paradigmas de uno y otro sexo. Tal y como lo ha mostrado George Vigarello, la historia de la belleza y la de la moda corren, en este sentido, en paralelo. Según dicho autor, en efecto, los ideales de belleza, en diálogo con los distintos paradigmas de normalidad impulsados por diversos saberes de época, cambian de la mano de las modas (Vigarello,

\footnotetext{
24 Para una exposición minuciosa de estas características propias de la sanción normalizadora véase Foucault ([1975] 2008, 207-215).
} 
[2004] 2009). Así, pues, los dispositivos de transformación y gestión técnica del cuerpo propios de la moda tienen en la belleza, en tanto ideal normalizante, un punto de referencia que los orienta y los dirige -véase en esta línea también los análisis de la feminista Susan Bordo $(1993,254)-$.

No obstante, las pautas de belleza resultan útiles no solo a la hora de disciplinar el cuerpo propiamente dicho, sino también a la hora de impulsar procesos de normalización referidos a la percepción social del mismo. La percepción social de los cuerpos y el grado de erotismo que se le atribuye a estos dependen, de hecho, de los cánones que cada época construye en torno a la belleza corporal. Dichos cánones, a su vez, se insertan dentro de políticas del deseo mas amplias que rigen las relaciones entre los sexos. La moda, así, por un lado disciplina los cuerpos, y por otro, los inscribe dentro de circuitos de deseo. Después de todo, uno de los principales recursos de la moda a la hora de gestionar los cuerpos es su promesa de hacerlos atractivos.

Esta inscripción del cuerpo vestido dentro de circuitos de deseo se da, a mi juicio, en el marco de lo que Adrienne Rich denomina heterosexualidad obligatoria (Rich, 1980). Según la escritora y crítica estadounidense, la heterosexualidad obligatoria designa un régimen de normalización del deseo a partir del cual se naturaliza la heterosexualidad y se plantean como inevitables una serie de prácticas de dominación en contra de los cuerpos clasificados como femeninos. La heterosexualidad obligatoria constituye, en esta medida, una institución política que faculta al poder masculino para administrar los cuerpos de las mujeres y para controlar su deseo. En tanto mecanismo normalizador, la heterosexualidad obligatoria descalifica toda economía del deseo ajena a la heterosexualidad calificándola de desviada o anormal. El carácter obligatorio de la heterosexualidad radica en el hecho de que las mujeres tradicionalmente

[...] contraen matrimonio porque es necesario, en orden a sobrevivir económicamente, en orden a tener hijos que no tengan que sufrir privaciones económicas u ostracismo social, en orden a ser respetables, en orden a hacer lo que se espera de [ellas] (...) y porque el romance heterosexual ha sido representado como la gran aventura femenina, y como un deber y una realización (Adrienne Rich, 1980, 654; traducción propia). 
De este modo, el poder patriarcal deplora las sexualidades contrahegemónicas (Rich se interesa particularmente en la invisibilización de la existencia lesbiana) en tanto cuestionan las normas heterosexuales y sus concomitantes instituciones.

Trasladando la crítica de Rich al campo del vestido, mi opinión es que la moda no se limita a disciplinar los géneros, sino que también identifica y marca los cuerpos, de modo tal que las normas sexuales sean ejecutables. La moda, en este sentido, clasifica los cuerpos según su género haciendo de la heterosexualidad una normatividad viable. La heterosexualidad obligatoria funciona, en esta medida, como una institución que administra y ejecuta las sanciones disciplinarias correspondientes para con los cuerpos que no se atienen a los preceptos dictados por las modas. En el entendido de que la sexualidad normalizada implica una orientación sexual específica, la moda hace, pues, que dicha elección se vuelva viable en la medida de su visibilidad.

La propia Rich concede a la vestimenta un rol destacado dentro de la heterosexualidad obligatoria. En su opinión, la alta costura y los códigos de vestimenta supuestamente propios de la mujer implican su confinamiento físico y el control de sus movimientos (Rich, 1980, 639). La moda, en este sentido, constituye una forma de controlar el cuerpo en nombre de unos roles y de un modelo de relacionamiento entre los sexos que son los que conforman el núcleo mismo de la heterosexualidad obligatoria.

Así, pues, la vestimenta afianza una equivocación debidamente señalada, entre otras autoras, por la feminista latinoamericana Gabriela Castellanos, a saber, la que consiste en presumir una continuidad entre el género, la orientación sexual y los "generolectos". Tal y como lo indica Castellanos, esa pretendida transversalidad de la heterosexualidad es en realidad el resultado de una confusión: no hay continuidad (o al menos no una continuidad ontológicamente necesaria) entre la identidad sexual -es decir, la identidad que se asume a partir del binarismo sexual-, la orientación sexual -esto es, la preferencia sexual por personas de uno u otro género- y los estilos de género o "generolectos" -es decir, la gestualidad que se asume como típica de uno u otro sexo-(Castellanos, 2006, 
27-35). La moda, sin embargo, constituye un esfuerzo por soldar esas esferas e instaurar una relación de mutua implicación entre las mismas (aún cuando la vestimenta también faculta a los individuos a establecer discontinuidades entre ellas; al respecto véanse los capítulos 5, 6 y 7 del presente trabajo).

En esta medida, el poder vestimentario no solo dota de una morfología al cuerpo, sino que instituye un orden a los placeres. Se trata de asignar una coherencia a una economía del deseo que algunos teóricos de la moda consideran amenazada, tal y como lo muestra el siguiente pasaje de la obra de Squicciarino:

[...] la idea de un uso no convencional de la indumentaria del sexo opuesto suscitaba, y todavía suscita, sobre todo en el hombre, un cierto disgusto que sería una defensa contra la posibilidad de que pudiera sentir una atracción erótica hacia personas del mismo sexo. Todos los individuos tienen potencialmente tendencias bisexuales: la mayor parte se caracteriza por tomar una dirección heterosexual, pero esto no excluye la posibilidad latente y siempre presente de regresión a un estadio bisexual u homosexual ([1986] 1998, 134; énfasis mío).

En tanto mecanismo disciplinador, por lo tanto, la moda asigna, tal y como lo muestra la cita de Squicciarino, un orden a los placeres. Las tendencias vestimentarias, al partir y a la vez afirmar el sexo dicotómico, permiten la normatividad heterosexual y juegan un papel de ordenamiento y distribución de los cuerpos (respecto de este punto me extenderé en el capítulo siguiente). De esta manera, la moda impulsa un sistema de sanciones relacionadas con la posibilidad de quedar por fuera de los circuitos eróticos. De la mano de los ideales de belleza que confieren erotismo a los cuerpos, los regímenes de heterosexualidad obligatoria encauzan el deseo y tildan de ilegítimos los placeres y los cuerpos que no se atienen a la normatividad en uso. En este sentido, la moda promulga y contribuye a sostener un régimen de placer heterosexual en el que se penaliza la desobediencia a las normas eróticas, así como el desacato de las codificaciones morfológicas del cuerpo. En una palabra, la moda no solo codifica los cuerpos de modo que estos resulten legibles, sino también de forma tal que estos resulten deseables. 
A partir de lo anterior resulta factible volver sobre las características asignadas por Foucault a la sanción disciplinaria expuestas al inicio de este apartado para examinar el modo en que estas se despliegan en el ámbito indumentario de la mano de los ideales de belleza y de la heterosexualidad obligatoria. En primer término, la moda involucra, ciertamente, una serie de mínimas sanciones para con todas aquellas expresiones vestimentarias que escapan a las normas, sin importar cuan nimias parezcan estas. En los casos examinados páginas atrás, por ejemplo -me refiero a los corsés, las pelucas y los mirriñaques-, es visible el interés por codificar los detalles: volúmenes, texturas y maneras de portar las prendas se regulan de forma atenta. Asimismo, las modas revelan una proclividad a reglamentar inclusive las partes más periféricas del traje, de modo tal que los accesorios (anillos, aretes, cadenas, etc.) reciben una atención especial, toda vez que un error en la elección de los mismos puede dar al traste con el equilibrio general de un traje y hacer que el usuario de modas pierda atractivo (así, por ejemplo, la prensa de modas puede calificar de "desastroso" el traje de una figura del espectáculo en arreglo al color de los zapatos o por efecto del acabado de un bolso). En segundo término, la desatención de ciertos preceptos de la moda puede implicar asimismo la "pérdida" de feminidad o de masculinidad. El caso de ciertas prendas que establecen en determinados momentos históricos criterios demarcatorios a nivel de género (piénsese en las faldas, los aretes o los pantalones) trae consigo, por ejemplo, la penalización social para quien ose utilizarlas de forma "inadecuada". La utilización de prendas que no se corresponden con "el propio sexo", de hecho, ha sido objeto de patologización en múltiples ocasiones y todavía hoy la diagnosis de la "personalidad intergenérica" se realiza con arreglo a la adecuación o inadecuación a las normas vestimentarias del "propio sexo" -véase al respecto el análisis de Butler acerca del uso patologizante de los vestidos por parte del Manual diagnóstico y estadístico de los trastornos mentales confeccionado por la Asociación Estadounidense de Psiquiatría (Butler, [2004] 2006, 140); volveré sobre estos usos impropios de las prendas en la tercera parte de este trabajo-. En tercer lugar, la moda sanciona, tal y como según Foucault ocurre a lo interno de los regímenes de normalización, a través del ejercitamiento de la norma. La normalización vestimentaria, como señalé más arriba, funciona, en efecto, sobre la base de la repetición correctora. Las prendas instalan sentidos y configuran cuerpos no en una dimensión meramente 
simbólica -como lo querría el análisis semiológico de Barthes-, sino temporal: el cuerpo despliega un imaginario morfológico y erótico sobre la base de un uso continuado. De ahí que modas que en principio resultan extravagantes acaben teniendo propiedades eróticas: la dimensión durativa de la moda, de hecho, es la que permite el desplazamiento de zonas erógenas, la producción epocal de fetiches y la organización del deseo con arreglo a imaginarios sobre la belleza y los géneros propios de cada tiempo. En cuarto lugar la moda establece dinámicas de sanción y gratificación ligadas fundamentalmente a la sexualidad. La atención a los dictados de la moda, en efecto, permite a los cuerpos entrar en relación erótica con otros cuerpos. Pero en la medida en que el vestido no solo impulsa sino que también visibiliza los vínculos eróticos, la moda faculta igualmente las sanciones para quienes rechazan los preceptos de la heterosexualidad obligatoria. La moda asigna mediante el vestido cargas eróticas a los cuerpos sexuados, pero en virtud de la hegemonía de la heterosexualidad obligatoria esas cargas se encuentran codificadas (en principio según el género, pero también según la edad, la clase social, etc.) de modo que el vestido, como lo señalé antes, posibilita la regulación de la sexualidad. Por último, la moda castiga, tal y como establece Foucault que ocurre en la sanción normalizadora, según una lógica jerarquizadora. En el ámbito de la indumentaria, de hecho, existe una serie de escalafones que van desde el individuo démodé a aquel que acata rigurosamente los mandatos de la moda. Acá la lógica penalizante opera asignando a los individuos un lugar dentro de una jerarquía que, de nuevo, posee consecuencias a nivel erótico. La desatención a los códigos vestimentarios según cada género amenaza a los individuos con hacerles perder atractivo. La fealdad asoma, así, como amenaza latente. Por lo demás, dentro de las escalas jerarquizantes de la moda hay una movilidad acuciante: se está a la moda, pero nunca de una forma permanente. Esta provisoriedad de los méritos permite una vigilancia permanente y, a la vez, hace de lo démodé un peligro constante: para estar a la moda no se requiere únicamente atenerse a la norma vestimentaria en uso, sino estar disponible para ser disciplinado por una norma vestimentaria venidera. La penalidad jerarquizante, en este caso, tiene además una última función: somete al conjunto de los individuos a una misma normativa, al distribuir los cuerpos en función de su atención o desatención a los preceptos de belleza. La relativa mutabilidad de los parámetros de la 
moda, así, genera una vigilancia moderna de todos hacia todos, en virtud de la cual se administra socialmente la sexualidad.

En términos generales, y a manera de recapitulación, puede hablarse, por lo tanto, de un poder vestimentario que normaliza el cuerpo por dos vías. De un lado, el vestido hace legibles los cuerpos confiriéndoles reconocimiento partir de su ubicación dentro de la grilla de inteligibilidad generizada, calificándolos así como bellos o feos según se adecuen o no a los preceptos de la moda. Del otro, el vestido dota los cuerpos de un atractivo erótico, estableciendo sistemas de sanciones que amenazan a los cuerpos con sustraerlos de los circuitos de deseo socialmente admitidos si no se atienen a las morfologías estipuladas.

En este sentido, considero que el disciplinamiento vestimentario establece vasos comunicantes con la normalización de la sexualidad. De manera acrítica, sin embargo, los estudiosos del vestido han pasado por alto este carácter normalizador que la vestimenta ejerce sobre los placeres, limitándose a señalar que el vestido tiene una función dentro de la economía erótica de la sociedad -véase, por ejemplo, Lurie ([1981] 2009, 237)-. Esta funcionalidad del vestido a la hora de establecer una normatividad sexual, sin embargo, posee una centralidad, dado que aparece dentro los sistemas de disciplinamiento como un enclave para los sistemas de vigilancia y de castigo..

En suma, si el género posee un carácter performativo que busca dotar al sujeto de una imposible estabilidad, y si, como lo he mostrado, el vestido es uno de los recursos de los cuales se echa mano para normalizar el deseo y establecer una continuidad entre las morfologías corporales disciplinadas y los placeres eróticos, entonces la relación de la moda con la sexualidad tiene una trascendencia quizá menospreciada: a través del disciplinamiento del género las modas tienen la capacidad de contribuir al establecimiento la heterosexualidad obligatoria. 


\subsection{Epílogo}

Al inicio de este capítulo señalé que los ejercicios de poder que la moda lleva a cabo en torno al cuerpo quedan disimulados mediante el ideal antropológico de un cuerpo "natural". Dicho ideal, según he señalado, parte de la diferencia sexual como un hecho natural y del tropo del cuerpo desnudo como su evidencia. De esta manera, la moda, a la hora de disciplinar el cuerpo y de imponer la heterosexualidad obligatoria como régimen de deseo hegemónico, establece una guerra en contra de la anormalidad en la que la late la amenaza para los individuos de devenir indeseables. En tal sentido, la moda se erige no únicamente como un mecanismo disciplinario que ejerce control sobre el cuerpo, sino también como una forma de poder que castiga lo anormal al tiempo que administra los placeres. Procedimientos de vigilancia, castigos normalizadores y heterosexualidad obligatoria: he ahí los principales rasgos de la moda considerada como una forma de disciplinar el género.

Sin embargo, dado que la moda, en tanto mecanismo de poder, no se agota en su dimensión disciplinaria, en el capítulo siguiente indagaré de qué manera este control de los cuerpos generizados y esta gestión de los placeres se da a un nivel macro bajo la forma de una biopolítica. 


\section{Capítulo 4. De las modas disciplinarias a las biopolíticas vestimentarias}

Si bien es cierto que la moda posee un talante disciplinador en lo tocante al género, también es cierto que dicho talante no agota todas las relaciones posibles entre el fenómeno del vestido y el ejercicio del poder. Como bien lo señala Foucault, al funcionar dentro de espacios acotados, las disciplinas tienen un alcance limitado en relación con la vida de las poblaciones (Foucault, [2004] 2009, 66). Siguiendo al teórico cultural francés Paul Virilio, Deleuze señala en este mismo sentido que existe un progresiva transformación en las sociedades occidentales a partir de la cual "las formas ultrarrápidas que adopta el control al aire libre (...) reemplazan a las antiguas disciplinas que actuaban en el período de los sistemas cerrados" (Deleuze, [1990] 1999, 278). En otras palabras, el poder disciplinario funciona dentro de circuitos concentrados y previamente recortados, fuera de los cuales su radio de acción disminuye.

En el caso de la moda, como he mostrado, las disciplinas se avocan fundamentalmente a la producción de los géneros. No obstante, otros desafíos de gobierno -en el sentido foucaultiano de dicha expresión- reclaman un tipo de control distinto. De ahí que las prácticas de disciplinamiento corporal se articulen con otras formas de poder. En relación con la moda y empleando una oposición hasta cierto punto esquemática, podría decirse que las estrategias de disciplinamiento vestimentario son eficaces cuando se trata de disciplinar morfologías singulares, pero que su influencia es menor cuando se trata de controlar de una manera más amplia la vida de las poblaciones. De todas formas, es claro que no existe un control eficaz de los cuerpos individuales que no coordine en un nivel más general las interacciones entre estos.

Para designar esta última modalidad de poder Foucault utiliza el término biopolítica. Según Foucault, dicho concepto se refiere a la administración y el control de la vida de las poblaciones consideradas en su dimensión biológica. En otras palabras, la biopolítica 
designa el conjunto de procesos mediante los cuales se busca gestionar la vida de la especie (Foucault, [2004] 2009, 415 y [2004] 2010, 359). La biopolítica, de esta forma, no se opone en modo alguno a las disciplinas, sino que, al contrario, ambas maneras de ejercer el poder se entrecruzan -superponiéndose, substituyéndose y retroalimentándoseformando así complejas redes.

Según Foucault, la biopolítica y las disciplinas constituyen, por lo tanto, dos variedades del biopoder:

[...] el poder sobre la vida se desarrolló desde el siglo XVII en dos formas principales; no son antitéticas; más bien constituyen dos polos de desarrollo enlazados por todo un haz intermedio de relaciones. Uno de los polos, al parecer el primero en formarse, fue centrado en el cuerpo como máquina. (...) El segundo (...) fue centrado en el cuerpo-especie, en el cuerpo transido por la mecánica de lo viviente y que sirve de soporte a los procesos biológicos (Foucault, [1976] 2005,168)

Sintetizando este punto de la argumentación foucaultiana podría decirse que las diferencias entre la biopolítica y las disciplinas vienen dadas por un asunto de objetivos: mientras la biopolítica remite a las poblaciones y al control de la vida de la especie, las disciplinas apuntan a la educación y el control de las aptitudes de los cuerpos. El poder disciplinario y la biopolítica conforman, de tal modo, dos conjuntos de prácticas diferenciables y analíticamente distinguibles, mas no por ello antagónicas. De hecho, se trata de formas de poder que exigen una articulación y que a menudo funcionan de manera complementaria. En suma, se trata de dos modalidades de poder que coexisten y que varían ante todo en razón de su objetivo: en un caso, desplegar una "biopolítica de la población", y en el otro, construir una "anatomopolítica del cuerpo humano" (Foucault, [1976] 2005,168).

Partiendo de esta perspectiva, en este capítulo quisiera sostener que si bien la moda funciona como mecanismo disciplinario cuando se trata de disciplinar morfologías singulares, en un nivel macro opera más bien a la manera de una biopolítica: esto es, como un dispositivo de poder que se despliega dentro de un conjunto general de tácticas 
en el marco del control de la vida de las poblaciones y de su relación con un territorio. En este sentido, lo que pretendo sostener en este capítulo es que la vestimenta, en tanto recurso de gobierno de los colectivos, lleva a cabo mecanismos de control social mediante sistemas de marcación que parten del género dicotómico como principio organizador, pero que no se agotan en él. Dentro de estas tácticas de gobierno que, siguiendo a Foucault, denominaré policiales, distinguiré tres mecanismos biopolíticos principales: por un lado, la codificación por vía de las prendas de las relaciones entre los sujetos que conforman una población; por otro, el control que, por intermedio del vestido, se lleva a cabo sobre las acciones de esa misma población; por último, la relación del cuerpo vestido con el territorio.

Mi propuesta, por tanto, es comprender la vestimenta como un instrumento biopolítico utilizado para gobernar los cuerpos generizados y su interacción en un marco social.

\subsection{Biopolítica, identidad y vestimenta}

Siendo que la biopolítica está ligada ante todo al poder sobre la vida -pues tal y como reza la célebre fórmula foucaultiana la biopolítica nace en razón de que "el viejo derecho de hacer morir o dejar vivir (propio del poder soberano) fue remplazado por el poder de hacer vivir o de rechazar hacia (sic) la muerte" (Foucault, [1976] 2005, 167)- su ámbito de intervención privilegiado está conformado por las diversas prácticas que buscan administrar la población en el marco de la convivencia dentro de un territorio. La biopolítica, de este modo, designa el conjunto de estrategias políticas dirigidas a resolver el desafío que comporta el gobierno de los individuos que conforman una población. Por esta razón, en la biopolítica, así como en las disciplinas, el gobierno de los cuerpos ocupa un lugar central.

A diferencia del poder disciplinario, sin embargo, la biopolítica tiene como blanco los cuerpos no ya en su singularidad sino en tanto y en cuanto conforman una "multiplicidad biológica" (Foucault, [1997] 2010, 228) -de ahí, quizá, la insistencia al interior de las 
teorías sobre la moda en imaginar el cuerpo desnudo como un cuerpo biológicamente virgen o en estado bruto: se trata de un enfoque que refleja el hecho de que en la moda hay en juego procesos de control de la vida-. Para la debida ordenación, distribución y control de las poblaciones se requiere, pues, de dispositivos de poder que garanticen un orden y que permitan hacer frente a la aleatoriedad.

Uno de esos dispositivos, a mi juicio, es la vestimenta. Tal y como lo he señalado en el capítulo anterior, la moda produce singularidades somáticas por medio del disciplinamiento del género. No obstante, a partir de los procesos de asignación del sexo de los cuales la moda forma parte, los sujetos son ubicados dentro de otras grillas de inteligibilidad que les permiten emerger y hacerse con una identidad abarcadora de algo más que un género. Por identidad debe entenderse acá, tomando en cuenta la crítica butleriana a dicho concepto reseñada en el capítulo anterior, no una subjetividad esencializada sino, precisamente, el resultado de una serie de procedimientos -dentro de los cuales se encuentra la moda- que generan la ilusión de una personalidad cerrada, al tiempo que hacen viable la ubicación de los cuerpos dentro de los parámetros de inteligibilidad social. En efecto, tal y como lo señalé en el capítulo anterior a partir de Butler (quien a su vez continúa el hilo de las críticas a las visiones metafísicas del sujeto propias de Nietzsche y Foucault), los mecanismos de asignación de identidad -los cuales funcionan de manera impositiva- son distinguibles de los procesos de identificación -en los cuales habría un espacio para el agenciamiento, la desidentificación y la fantasía(Butler, [1993] 2008, 70-85). En este sentido, según Butler, el tropo de la identidad genera una serie de réditos en términos de control social. Para Butler, toda vez que la identidad es un constructo ficcional que busca dar estabilidad y continuidad al sujeto, dicho concepto remite a prácticas reguladoras que intentan clasificar los cuerpos. En otras palabras, tal y como lo apunta Femenías, para Butler "el locus sujeto es sólo cuando es nombrado, mencionado o interpelado" (Femenías, 2003, 112). Así, partiendo con la filósofa norteamericana de que, "la identidad es un efecto de las prácticas discursivas" (Butler, [1990] 2007, 73) y no una verdad estable, considero que el vestido opera como un dispositivo biopolítico que, al contribuir a los procesos de asignación identitarios permite clasificar, ordenar, distribuir y normalizar los cuerpos que conforman una 
población determinada. En este sentido, tal y como lo señala también Almudena Herrando, "la uniformización de la apariencia no solo expresa, sino que además genera adscripción" $(2012,134)$ : mediante las modas se producen, ciertamente, procesos de homogenización a través de los cuales se construyen lealtades y pertenencias grupales que redundan en la producción de identidades. El vestido opera así, según Herrando, como un elemento que posibilita el ingreso -o que en su defecto lo niega- a matrices identitarias.

Así, a partir de mi interpretación de estas autoras, considero que mediante un trabajo sobre el cuerpo y su apariencia, la moda hace posible la clasificación social de las subjetividades mediante procedimientos de inscripción de los organismos dentro de distintas grillas de inteligibilidad. Considero, en tal medida, que el vestido posee una utilidad biopolítica pues, en tanto dispositivo distribuidor de identidades, genera tramas de reconocibilidad social (me detendré a propósito de este tema más adelante en este mismo capítulo). En otras palabras, si las modas no se limitan a reflejar las distintas identidades sociales sino que contribuyen a producirlas (a partir de un cuerpo que, como lo argumenté en los capítulos anteriores, se imagina a menudo como naturaleza), la puesta en circulación de tendencias vestimentarias tiene que ver con procesos de gestión corporal de las poblaciones y con sistemas de diferenciación y jerarquización de los individuos.

El vestido, sin embargo, no reconoce y organiza el conjunto de cuerpos que conforman una población únicamente en razón del género. La eficacia del vestido en tanto mecanismo biopolítico reside, por el contrario, en su funcionalidad a la hora de producir identidades complejas (abarcadoras, v. gr., de ejes como lo etario, lo étnico, lo profesional, etc.) y con ello controlar múltiples asuntos referidos a la vida de las poblaciones. En esta medida, considero que la utilidad biopolítica del vestido data de tiempos remotos -suscribo en este punto la argumentación esgrimida por Esposito según la cual resulta conveniente no restringir los análisis biopolíticos a las coordenadas espaciotemporales definidas originalmente por Foucault. Para Esposito, en efecto, lo constitutivo de la noción de biopolítica es la tensión que establece entre política y vida, 
una tensión que, según este autor, se habría inaugurado mucho antes de la Modernidad (Esposito, [2004] 2011, 53-66)-. De hecho, las tendencias vestimentarias han funcionado tiempo ha como sistemas de marcación corporal que denotan una supuesta identidad, pero que en verdad, utilizan la corporalidad como fuente de producción de subjetividad. En otras palabras, el vestido opera transversalmente a lo largo de la historia como un medio material para la construcción ficcional y políticamente interesada de identidades no solo a nivel de género, sino también a nivel de otros vectores identitarios.

La vestimenta así constituye un recurso de gobierno utilizado de diversas formas a lo largo de la historia según el "régimen de identificación" en el cual se inscriba. Los "regímenes de identificación", tal y como los conciben los historiadores franceses About y Denis siguiendo a Foucault, designan las configuraciones históricas particulares conformadas por las relaciones entre diversos dispositivos como el vestido, el nombre y los documentos a partir de las cuales se identifica a los sujetos ([2010] 2011, 12). La moda, entonces, opera como dispositivo biopolítico en la medida en que, en coordinación con otros elementos identificatorios, genera sistemas de organización en torno a los cuerpos y las conductas realizadas por los mismos, así como mecanismos para asignar identidades a las distintas franjas poblacionales. El vestido, en este sentido, ofrece múltiples posibilidades a la hora de construir identidades imaginarias con alcances morales y políticos. En síntesis, podría decirse que la vestimenta opera como mecanismo biopolítico en el sentido de que constituye un mecanismo de marcación corporal que dota de legibilidad social a los cuerpos y los distribuye y jerarquiza en el marco de un territorio.

\subsection{La vestimenta como dispositivo policial generizado}

Esta labor de configuración y clasificación de los cuerpos mediante sistemas de marcación podría ser considerada, foucaultiano sensu, como una labor policial. En el contexto de la historización foucaultiana del término "policía" dicha noción designa el conjunto de técnicas gubernamentales aplicadas al interior de un territorio por parte de un 
gobierno (Foucault, [2004] 2009a, 355-362). Dentro del análisis foucaultiano, la policía es la encargada de velar por la seguridad de la nación y abarca, por ende, una amplia gama de cuestiones: desde la administración de lo común por parte de la autoridad pública en el siglo XVII, hasta el buen uso de las fuerzas del Estado y la manutención de la seguridad dentro de los dominios territoriales de este en el siglo XVIII. En este sentido, la policía constituye el eje gubernamental a través del cual es posible velar por una adecuada interacción entre la población y el entorno en el que esta se desenvuelve.

La moda, en tanto mecanismo de gobierno de las poblaciones, opera en mi opinión a la manera de un dispositivo policial. Partiendo de la ubicación de los cuerpos dentro de la grilla de inteligibilidad sexual -pero también dentro de otras grillas- el vestido posibilita, en efecto, un control tanto de la relación de los individuos entre sí, como de su relación con el espacio que habitan. ${ }^{25}$ A partir del disciplinamiento de género, una serie de dispositivos policiales se despliegan, efectivamente, a fin de regular la vida del conjunto de los individuos. Los géneros operan, en tal medida, como casillas primarias que orientan otras inscripciones identitarias más.

En otras palabras, según creo, el vestido constituye un recurso de gobierno en lo tocante a la administración del conjunto de los cuerpos de la población y al control de su circulación. A partir de la producción de la diferencia sexual que la moda contribuye a generar, el vestido, en tanto técnica policial, se revela así como un mecanismo que marca los cuerpos con un género, pero que a partir de dicha marcación, también los relaciona y distribuye en el marco de un espacio territorial a partir de otros ejes identitarios. Por otra parte, la vestimenta regula continuidades y pretende garantizar las debidas conexiones entre el aspecto y los comportamientos, así como evitar desfases entre los mismos. En esta medida, la moda opera como un dispositivo que instaura un orden social y que genera redes de jerarquías y formas de reconocimiento (en el sentido butleriano de esta última expresión, es decir, formas de interpelación que habilitan al sujeto pero que al mismo tiempo apuntan a sujetarlo; volveré sobre dicho concepto en breve) que redundan

\footnotetext{
${ }^{25}$ Sobre la relación entre biopolítica y control social, véase Foucault ([1976] 2005, 168), así como Hardt y Negri ([2000] 2006, 19-50).
} 
en una mayor gubernamentalidad de las poblaciones. Así, como se vera más adelante, el control de las poblaciones orbita en torno a la vestimenta de diversos modos, según sean las características del régimen de identificación dominante en cada época.

Si bien es cierto la comprensión foucaultiana de lo policial y de la biopolítica no incluye una perspectiva de género (pues como lo indiqué en la introducción de este trabajo, el pensamiento de Foucault, en general, no utiliza dicha perspectiva), la centralidad de éste eje dentro del panorama que intento dibujar es manifiesto: baste reparar en el hecho de que el dispositivo de sexualidad constituye, según el propio Foucault, un punto de intersección privilegiado entre las técnicas disciplinarias y las biopolíticas, y en que dicho dispositivo - pese a las omisiones de Foucault- depende enteramente del género para su funcionamiento. $^{26}$

Considero, por tanto, que analizar la vestimenta en términos biopolíticos requiere una perspectiva generizada que permita comprender de qué manera los dispositivos policiales impulsados por el vestido parten del sexo como grilla de inteligibilidad primaria a partir de la cual se despliegan varias otras técnicas policiales dirigidas a gobernar las poblaciones. En otras palabras, si la moda opera sobre los cuerpos disciplinando su género y estableciendo paradigmas de normalización sexual, cabe pensar que a un nivel macro la moda funciona asimismo regulando -a la manera de un dispositivo policialotras dimensiones de la vida corporal. Dichas dimensiones, sin embargo, tienen en el cuerpo sexuado su punto de partida fundamental. Como he intentado mostrar anteriormente, la moda, de hecho, encuentra su legitimidad a la hora de manipular el cuerpo a partir de la base de su supuesto estatuto natural, pero dicho estatuto, a su vez, parte del género como dato natural incontrovertible. A partir de esa clasificación primaria de los cuerpos con base en el sexo, la biopolítica vestimentaria realiza entonces un trabajo policial sobre el conjunto de los cuerpos imaginando dicho conjunto en términos de especie. En tal sentido, la moda no constituye únicamente un dispositivo disciplinario dirigido a darle unos contornos determinados a los cuerpos, sino también un mecanismo

\footnotetext{
${ }^{26}$ En relación con los vacíos que poseen a nivel de género los estudios sobre biopolítica véase Preciado $(2008,35)$.
} 
que permite gestionar la propia vida de esos cuerpos: sus interacciones, sus relaciones con el espacio y sus rituales, por ejemplo.

Partiendo del cuerpo generizado como grilla de inteligibilidad matricial, por tanto, es posible identificar tres tipos de dispositivos policiales diferenciados -aunque íntimamente conectados y en la práctica indefectiblemente articulados- en torno a la vestimenta. En primer lugar, los referidos a los procedimientos de codificación de las relaciones sociales, los cuales agruparé bajo la categoría "dispositivos interaccionales". En segundo lugar, los referidos al control de las acciones de la población, a los cuales denominaré "dispositivos ceremoniales". Finalmente, creo que podría distinguirse un último grupo de dispositivos policiales vestimentarios vinculados al control de los desplazamientos y emplazamientos dentro de los distintas regiones que conforman un territorio. Propongo llamar a este último grupo "dispositivos espaciales". En los siguientes apartados de este capítulo caracterizaré, por tanto, cada uno de estos tres dispositivos vestimentarios.

\subsection{El dispositivo interaccional}

Uno de los desafíos de gobierno que comporta la vida de las poblaciones consiste en la regulación de las relaciones entre los distintos sujetos sociales. Toda vez que en el marco de la vida de las poblaciones no todos los cuerpos poseen el mismo rango, una estrategia de gobierno consiste precisamente en gestionar dichos rangos y en establecer y mantener jerarquías sociales. En otras palabras, en el marco de la gestión biopolítica de las poblaciones es menester clasificar jerárquicamente los cuerpos, los cuales, paradójicamente, también son producidos, en parte, por esas mismas clasificaciones. Por tanto, la pregunta acá es cómo los regímenes de producción y clasificación somática entre las cuales considero que la moda juega un papel fundamental- establecen parámetros de relacionamiento entre los cuerpos como parte de la gestión biopolítica de las poblaciones. 
En Tres guineas ([1938] 1999), su carta/ensayo dedicada a reflexionar en torno al tema de la guerra y su relación con las desigualdades de género, la escritora británica Virginia Woolf describe con precisión el modo en que la vestimenta es utilizada como una manera de establecer jerarquías sociales. Según ella, el cuerpo es afectado de tal manera por las tradiciones que la constitución física de los géneros depende directamente del modo en que las costumbres y la historia se asientan en el cuerpo:

[...] ningún psicólogo o biólogo negará que [1]as diferencias [de acceso al capital y la tierra] comportan muy considerables diferencias en la mente y en el cuerpo. De lo cual parece seguir (sic) el indiscutible hecho de que "nosotras" -y este "nosotras" significa una unidad integrada por cuerpo, cerebro y espíritu, sometida a la influencia del recuerdo y las tradiciones- forzosamente seguimos siendo diferentes de "[ustedes]", cuyo cuerpo cerebro y espíritu han sido diferentemente educados y son diferentemente influenciados por recuerdos y tradiciones (Woolf, [1938] 1999, 33).

Para Woolf la vestimenta forma parte de un conjunto de factores que se avocan a perpetuar las diferencias de género y de rango: a través de las prendas la moda sería capaz, por tanto, de variar las morfologías corporales, tal y como lo indiqué en el capítulo anterior. No obstante, el señalamiento de Woolf va un paso más allá al indicar que las prendas no se limitan a impactar en los cuerpos singulares sino también en el modo en que estos se relacionan en un marco social más amplio. En otras palabras, como lo señala más recientemente el antropólogo francés David Le Breton, "en las condiciones comunes de la vida social, etiquetas sobre el cuerpo rigen las interacciones" ([1992] 2011, 78).

Según Woolf, en efecto, la moda incide en la manera en que los cuerpos interactúan en sociedad. El vestido instaura, en su opinión, una serie de jerarquías que afectan las interacciones entre varones y mujeres, generando lo que en la terminología del sociólogo estadounidense Irving Goffman se denominan "expectativas normativas", a saber, una serie de demandas morales que se producen en la interacción social y que incluyen anticipaciones y demandas en relación con la conducta de los otros (Goffman, [1963] $2010,14)$. En otras palabras, para Woolf, la vestimenta contribuye no solo a producir diferencias corporales sino también parámetros a partir de los cuales percibir dichas diferencias. 
Dentro de una lectura bulteriana de Woolf, lo que estaría en juego acá es la configuración visual de los parámetros de reconocibilidad. El reconocimiento, tal y como Butler lo concibe siguiendo a Hegel, designa el drama de la conciencia mediante el cual los individuos caen en cuenta de, y se ven obligados a, aceptar de la existencia de los otros. ${ }^{27}$ Dentro de los sucesivos estadios de la conciencia hegeliana, en efecto, el encuentro de los sujetos deseantes con otros sujetos deseantes introduce un cortocircuito en los itinerarios del deseo: el cuerpo, acostumbrado a devorar los objetos que anhela, se ve en la necesidad, mediante su encuentro con el Otro, de luchar por el reconocimiento, al tiempo que se enfrenta al dilema de reconocer a ese Otro (Hegel, ([1807] 2009, 115). Para Butler, este fenómeno del reconocimiento descrito por Hegel se refiere tanto a la posibilidad de emerger como un sujeto como a la posibilidad de ser sujetado por una norma. Por otro lado, los parámetros a partir de los cuales se llevan a cabo dichos procesos de reconocimiento dependen, en opinión de Butler, de parámetros ontológicos que se dirimen epocalmente. Partiendo de una suerte de lectura butleriana de Virginia Woolf como la que deseo proponer aquí, podría decirse, pues, que la vestimenta no solo afecta la manera en que los cuerpos generizados se constituyen en su materialidad, sino también la manera (ciertamente diferencial) en que esos mismos cuerpos son objeto de reconocimiento social. En otras palabras, según Virginia Woolf, la vestimenta es un recurso que hace reconocibles los cuerpos generizados, pero que al mismo tiempo materializa corporalmente jerarquías (Woolf, [1938] 1999, 37).

Sin embargo, como lo sugiere la propia Woolf, la vestimenta no solo contribuye al control de las relaciones entre los cuerpos ateniéndose a la codificación del género (Woolf, [1938] 1999, 38-39). A partir de dicha codificación, por el contrario, la totalidad de las relaciones sociales es afectada por la vestimenta (si bien a juicio de la autora todas las relaciones sociales son experimentadas por sujetos generizados). La ensayista británica se refiere, así, a una gradación del prestigio social generada por la ropa, paradójicamente invisible por el efecto de la repetición (con Butler diríase "performativa"). De ese modo, "la singularidad de[1 atavío del juez], igual que la del

\footnotetext{
${ }^{27}$ Sobre el tema del reconocimiento véase Hegel ([1807] 2009, 113-120) y Butler ([1993] 2008, 88-103).
} 
atavío de los almirantes, generales, pares del reino, alabarderos, reyes de armas, etc. resulta (...) totalmente invisible a su vista" (Woolf, [1938] 1999, 35), a pesar de la influencia social que ejercen sus atuendos. Las prendas, en esta medida, construyen identidades normativas complejas y abarcadoras de múltiples vectores que, partiendo del género, atañen a diversas facetas identitarias además del sexo. Así, a partir de Woolf es posible sostener que la vestimenta se utiliza en el marco del gobierno de las poblaciones como un mecanismo que permite tanto la producción y clasificación social de diversas identidades como el control de la relaciones entre las mismas.

Esta producción y clasificación social de las identidades a través de las tendencias en el vestido constituye un dispositivo policial que permite la gestión de buena parte de la lógica interaccional de los individuos de la población. Si, como lo señala el sociólogo peruano Aníbal Quijano, toda clasificación social es ya de por sí una lucha "por el control de los ámbitos básicos de existencia social [a partir] de cuyos resultados se configura un patrón de distribución del poder centrado en relaciones de explotación / dominación / conflicto entre la población de una sociedad" (Quijano, 2010, 367), en el caso de la clasificación social de los cuerpos llevada a cabo mediante los vestidos, lo que está en juego es nada menos que el establecimiento de pautas normativas político/corporales para la interacción social. De este modo, siguiendo a Woolf, considero viable sostener que las prendas y las modas imprimen una lógica jeraquizadora a las relaciones sociales entre los cuerpos al producir rangos e instaurar asimetrías. En una palabra, "las ropas no solo cubren la desnudez, halagan la vanidad, placen a la vista, sino que sirven para proclamar [advertise] el rango social, profesional o intelectual de quien las lleva" (Woolf, [1938] 1999, 37).

Nótese que contrariamente a lo señalado por los análisis semiológicos mencionados en el primer capítulo, en la línea argumentativa que intento desarrollar acá a partir de Woolf, Foucault y Butler, las prendas no se limitan a significar un poder, sino que la propia utilización performativa de la prenda es la que dota a los cuerpos de un rango social, en la medida en que toda jerarquía depende, en parte, de la reiteración de unas prácticas vestimentarias determinadas. A partir de una interpretación focaultiano/butleriana de 
Woolf podría decirse, entonces, que las prendas establecen biojerarquías performativas, por medio de una suerte de "etiquetado diferencial" de los miembros de la población.

Respecto de esta lógica clasificatoria, señala Woolf:

[...] las ropas masculinas cumplen la misma función que los cartelitos en las tiendas de víveres. Pero en vez de decir "esto es margarina; esto es mantequilla pura; esta es la mejor mantequilla que hay en el mercado", dicen "Este hombre es un hombre inteligente, es licenciado en Artes; este hombre es un hombre muy inteligente, es doctor en Letras; este hombre es sumamente inteligente, es miembro de la Orden del Mérito (Woolf, [1938] 1999, 37).

Así, el dispositivo vestimentario interaccional, que no es otra cosa que esta producción y categorización diferencial de los individuos a partir de sus vestidos descrita por Woolf, conforma un poderoso recurso policial que determina las lógicas con que los diversos sectores de una población se relacionan.

De este modo es que, por ejemplo, los uniformes de jueces, soldados y autoridades religiosas, instituyen performativamente una autoridad que configura las relaciones de esas profesiones con el resto de la población. Dentro de la opinión teórica usualmente aceptada en relación con este punto, la vestimenta no asigna ningún poder, sino que por el contrario se limita a visibilizarlo. A criterio de Heath y Potter, por ejemplo, "el hecho de que el uniforme se use para reforzar una jerarquía social inadecuada no es un argumento a favor de eliminar el uniforme, [toda vez que] lo que habría que eliminar es la jerarquía social" (Heath y Potter, [2004] 2005, 197-198, subrayado mío). Con ello, los autores suponen que los rangos sociales son independientes del modo en que los cuerpos se presentan y, en esta medida, hacen pervivir la vieja dicotomía entre una forma de dominación corporal y otra que por el contrario atañe únicamente a la subjetividad, cuando lo cierto es que, tal y como lo señala Woolf, la dominación corporal tiene una relación de identidad con aquella que se ejerce sobre los sujetos. En una palabra, las jerarquías sociales no son independientes de los signos que las producen. 
En la perspectiva foucaultiana/woolfiana que suscribo acá, por tanto, no hay jerarquías sociales independientes de los cuerpos que, ora sacan provecho de ellas, ora las padecen. En efecto, como lo indica el teórico cultural alemán Friedrich Weltzien, "la persona uniformada tiene licencia para hacer cosas que los otros no tiene permitido hacer, por ejemplo interrogar, arrestar o incluso disparar a ciertas personas" (2005, 240; traducción propia). ${ }^{28}$ El ejercicio de la autoridad, en esta medida, constituye una situación corporal que depende de los modos en que se presenta el cuerpo. ${ }^{29}$ En este sentido, lo señalado por Foucault en relación con el mundo militar, a saber que "el soldado es en primer lugar alguien a quien se reconoce de lejos" ([1975] 2008, 157), resulta extensible a muchas otras situaciones sociales en las cuales se encuentra involucrado el cuerpo vestido.

Dentro de esta visión, de hecho, las modas constituyen formas de uniformar más que vías para la singularidad. La tendencias vestimentarias, en esta medida, son conceptualizables como sistemas informales de atribución de capacidades que catalogan diferencialmente a los individuos. En el marco de esta visión ampliada del uniforme, las tendencias vestimentarias, de hecho, constituyen una suerte de dispositivo de regulación de las interacciones. De hecho, como lo señala el sociólogo francés Paul Yonnet, "cuando el vestido no está adaptado a una actividad, quien lo usa ve prohibida su práctica en el mejor de los casos y sancionada en el peor de ellos" ([1985] 2005, 236). Desde este marco, puede decirse entonces que la articulación activa de la prenda y el cuerpo instituye performativamente una autoridad que no es sencillamente la del signo, sino una que surge de las interacciones vivas entre los cuerpos.

El dispositivo interaccional, no obstante, también tiene puntos de anclaje por fuera del ámbito de las profesiones, las cuales, en todo caso, son tan permeables a las modas como cualquier otra práctica vestimentaria -baste recordar que ya Baudelaire hablaba de una "coquetería militar", subrayando así la dimensión estética propia de los uniformes de ese

\footnotetext{
${ }^{28}$ Sobre la extensión en el uso de los uniformes por fuera del ámbito religioso -su ámbito de utilización original- véase About y Denis $(2011,26)$. Sobre la importancia del uniforme en el mundo militar consúltese Rivière (1977, 42) y Pastoureau (2005, 46-47)

${ }^{29}$ Para un análisis sobre el modo en que el cuerpo uniformado del policía se constituye como el punto axial en el que se soportan los imperativos que forman al sujeto policial y su autoridad, véase Sirimarco (2010, 193). Foucault, por otra parte, considera que el cuerpo del psiquiatra también se construye como un punto de emisión de autoridad (Foucault, 2008b, 213-214).
} 
gremio (Baudelaire, [1862] 1995, 110)-. Me refiero a que todas las modas incluyen, sin importar si de ello son conscientes quienes las diseñan o las portan, paradigmas de relacionamiento que acaban incidiendo en las tramas de vinculación moral entre los sujetos de la población en cuestión. Así, por ejemplo, la irrupción de las modas juveniles en el siglo XX impactó significativamente las relaciones etarias: una vez que la mayoría de la población comenzó a aspirar a lucir joven, la antigua veneración moral hacia quienes vestían como personas mayores quedó en el olvido. El diseñador de modas Yves Saint Laurent sintetiza este cambio de forma adecuada cuando indica que "antes, una hija quería parecerse a su madre, [mientras que] actualmente sucede lo contrario" (citado por Lipovetsky, [1987] 2009, 135). ${ }^{30}$

Por otra parte, ciertas prendas relacionadas con estigmas sociales también pautan moralmente las relaciones entre quienes padecen dicho estigma y el resto de la población. La marcación y concomitante marginalización de los delincuentes a través de las prendas, por ejemplo, se remonta hasta la Edad Media. En esa época, de hecho,

[...] se señaló con ropajes o atributos listados a todos aquellos que se situaban fuera del orden social, ya fuese en razón de una condena (estafadores, falsificadores de moneda, perjuros, criminales), de un defecto (leprosos, falsos devotos, simples de espíritu, locos), o porque ejercieran una actividad inferior (criados, sirvientas) o un oficio infamante (juglares, prostitutas y verdugos) (...), ya fuese, finalmente porque no fuesen o hubiesen dejado de ser cristianos (musulmanes, judíos, herejes) (Pastoureau, [1991] 2005, 24).

Con la entrada de la modernidad, estos sistemas de marcación de los cuerpos marginales conocerán, de hecho, un importante desarrollo como parte del despliegue de los dispositivos de seguridad. En ese marco, los mecanismos policiales de identificación aspirarán a hacer reconocibles a todos aquellos sujetos considerados peligrosos debido al supuesto riesgo que los mismos representan. ${ }^{31}$ Sin embargo, más allá de estas diferencias

\footnotetext{
${ }^{30}$ La utilización de la ropa como recurso de marcación de la diferencia etaria ha sido objeto de atención también en El Emilio (Rousseau, [1762] 2000, 146). Véase al respecto, además, Martínez Barreiro (2006, 199), Entwistle, ([2000] 2002, 154-155), Lipovetsky ([1987] 2009, 129), Lurie ([1981] 2009, 57-61) у Godart ([2010] 201267-68).

31 Sobre la construcción de la categoría "individuo peligroso" como forma de designar a sujetos considerados eventualmente riesgosos para el resto, y sobre la correspondiente exigencia social de crear
} 
epocales, lo cierto el que el vestido se erige históricamente como un mecanismo que opera marcando los cuerpos según los distintos estigmas sociales de cada período histórico.

Sintetizando, podría decirse que no obstante las diferencias epocales y el carácter ya sea positivo o negativo de la marcación efectuada por las distintas prendas empleadas para tales efectos, el dispositivo vestimentario interaccional se caracteriza por imponer marcas visuales distintivas y jerarquizadoras de los diversos segmentos de la población. La importancia biopolítica de este dispositivo radica, por tanto, no únicamente en el hecho de que permite el establecimiento de parámetros de reconocibilidad social, sino también en el hecho de que a partir de esos parámetros, se instauran pautas obligatoria de relacionamiento moral entre los individuos que conforman una determinada población.

\subsection{El dispositivo ceremonial}

Así como las prendas contribuyen a generar y clasificar identidades y a establecer parámetros de relacionamiento socio-moral entre los sujetos/sujetados por medio de dichas prácticas clasificatorias, los dispositivos vestimentarios son igualmente útiles cuando de controlar acciones y conductas se trata. En el capítulo anterior analicé el modo en que, en el marco de las instituciones disciplinarias, ciertas prendas, al contribuir a producir el género, concitan movimientos y cohíben acciones. Dentro de un marco biopolítico, en cambio, me interesa analizar más bien el modo en que funcionan esas propiedades directivas de las conductas propias de los atuendos en el contexto del gobierno de las poblaciones. El desafío gubernamental que comporta el dispositivo ceremonial, por tanto, consiste en determinar cómo y hasta dónde controlar lo que los cuerpos generizados que conforman una población llevan a cabo.

formas de marcación corporal que identifiquen a los mismos por mor de la seguridad social, véase Foucault ([1978] 2010). 
De nuevo, el ensayo de Virginia Woolf traído a colación en el apartado anterior resulta particularmente clarificador para desarrollar este punto. Si bien Simmel ya había advertido que los "hombres trajeados de la misma manera se comportan con cierta uniformidad" ([1905] 2008, 77), al carecer de una perspectiva de género, su filosofía de la moda acaba presuponiéndole cierta naturalidad al cuerpo sexuado (véanse capítulos 1 y 2). Para la autora británica, en cambio, las prendas generan una moral corporal que desplaza históricamente los límites de lo que los cuerpos generizados pueden hacer. La escritora inglesa caracteriza este tipo de gestión corporal como un mecanismo cuyo modus operandi es asimilable al de las ceremonias.

Dentro de esta línea, y caracterizando el comportamiento masculino de su época, escribe Woolf:

[...] más extrañas todavía que el simbólico esplendor de sus ropas son las ceremonias que se celebran cuando las llevan puestas. Aquí se arrodillan; allá hacen una reverencia; aquí avanzan en procesión detrás de un hombre portador de una maza de plata; aquí ascienden por una escalera de madera labrada; aquí rinden homenaje a una porción de madera pintada; aquí se humillan ante mesas cubiertas de ricos tapices. Y, sea lo que fuere lo que estas ceremonias significan para ustedes, siempre las efectúan juntos, al unísono, siempre con el uniforme adecuado al hombre y a la ocasión (Woolf, [1938] 1999, 36-37).

En opinión de Woolf, esta especie de ritualística masculina se opone punto por punto al conjunto de preceptos que la moda impone a las mujeres. A partir de este reconocimiento del carácter diferencial del tratamiento que se da a los cuerpos a partir del género, sin embargo, la ensayista británica abre la posibilidad de examinar el papel de estas prácticas ceremoniales en un marco social más abarcador.

En efecto, según Woolf, el establecimiento de ceremonias corporales a partir de las prendas tiene que ver, por un lado, con un universo simbólico masculino y burgués particularmente proclive a la afectación y la solemnidad, pero por otro, con la capacidad de la prenda propiamente dicha de actualizar (con Butler podría añadirse "performativamente") unos poderes. Con esto quiero decir que para Woolf no es posible portar ciertas prendas sin comportarse de un cierto modo en sociedad. La feminista 
inglesa, de hecho, ubica un foco de disidencia en la renuencia por parte de los individuos a ser in/vestido por ciertas modas, por lo que recomienda a las mujeres prescindir de "medallas, cintas, cruces, birretes y togas, y no por aversión al personal adorno, sino por el evidente efecto restrictivo de ellas, por su propensión a estereotipar y destruir" (Woolf, [1938] 1999, 200).

Dentro de una perspectiva similar, Almudena Hernando hace referencia el modo en que los cuerpos actúan en diferentes registros ceremoniales según los géneros y los contextos en que estos se encuentran inscritos. Para la antropóloga española, en efecto, los procesos de adscripción, inscripción y desincripción de los cuerpos dentro de rituales sociales a partir del vestido, constituyen un elemento históricamente constante en la vida de las poblaciones humanas. Según Hernando, siendo que las identidades sociales requieren de una cierta trama relacional, las prendas funcionan adhiriendo a los individuos a grupos así como a los rituales propios de los mismos. De este modo, para la autora, la pertenencia grupal se da por medio de elementos metonímicos que provocan conductas corporales (Hernando, 2012, 135). En esta medida, la pertenencia grupal por medio del vestido no solo cumple la función de integrar o excluir al individuo, sino que además lo inserta dentro de tramas y tejidos ceremoniales que les proveen una identidad social y que, en esa medida, codifican sus comportamientos no solo en relación con sus congéneres sino también con otros grupos. A manera de ejemplo, Hernando describe el modo en que estas propiedades del vestido operan en el marco académico:

[...] si volvemos a dirigir la mirada a la cultura material que rige la lógica de la apariencia en el mundo académico, veremos que cuanto más idealiza una sociedad el conocimiento científico, paradójica pero no sorprendentemente (...), más símbolos religiosos y ceremoniales utiliza en la vestimenta de quienes lo representan. Ninguna otra profesión actual presenta el tipo de ropaje religioso y ritualizado que define la llamada vestimenta académica (...). Participar en una de sus ceremonias es reproducir un ritual antiguo, completamente codificado, donde togas, bucetas, puñetas y birretes recuerdan necesariamente la vestimenta clerical de la que proceden (Hernando, 2012, 143-144). 
Siguiendo con su ejemplo, Hernando subraya el modo en que la dimensión ceremonial de la vestimenta académica se proyecta hacia fuera del espacio público, dotando al científico no solo de un modo de interactuar dentro de su espacio sino también a la hora de desplegar su subjetividad en el marco de otras interrelaciones. Para la autora, la vestimenta académica, de hecho, imprime su impronta en la relación que el científico establece con quienes no comparten su rango: el vestido opera en su opinión, por tanto, como un elemento material que codifica los rituales sociales en los que la subjetividad académica toma parte.

A partir de los argumentos y ejemplos de Woolf y Herrando considero, por lo tanto, que las prendas poseen un poder material sobre las actuaciones de los cuerpos de la población y que, en esa medida, las modas tienen la capacidad de hacer que estos procedan en sociedad atendiendo un sinnúmero de preceptos morales y respondiendo a unos ritmos sociales determinados. La idea woolfiana de un cuerpo susceptible de ser destruido por la moda refiere precisamente a un tipo de relación entre las prendas y lo somático en la que la indistinción cabal entre ambos elementos acaba determinando lo que los sujetos pueden o no hacer, sin importar si dichas acciones son o no ejercidas dentro de espacios acotados.

Los rituales generados por la moda, por lo tanto, responden en esta medida a una impronta policial a partir de la cual la identidad social que se asigna a los cuerpos de la población determina aquello de lo que esos cuerpos son capaces. De hecho, como lo señala Judith Butler, la apariencia corporal puede llegar a decidir, en el límite, si un cuerpo resulta socialmente ilegible o no (Butler, [1993] 2008), con lo cual las capacidades de acción de cada quién resultan profundamente dependientes de estos procesos de reconocimiento de la subjetividad. La compleja urdidumbre conformada por la relación entre las identidades, las prendas y las capacidades corporales acaba generando, así, diversas lógicas ceremoniales según el sector de la población del que se trate, y a partir de dichas lógicas es que se hace posible la codificación social de las conductas y su puesta en relación. En otras palabras, a través de las prendas se lleva a 
cabo la labor biopolítica de producir y coordinar diferentes ceremonias sociales determinando el modo en que los cuerpos se comportan.

Un ejemplo, quizá algo extravagante, resulta útil para mostrar la forma en que esto sucede, toda vez que hiperboliza el rasgo del dispositivo vestimentario que deseo destacar acá. Me refiero al imaginario de los superhéroes analizado por Weltzien (2005). Según el autor alemán, dicho imaginario pone de relieve el hecho de que los distintos roles e identidades sociales asignados a cada cuerpo son regulados por el traje. En esta medida, la convergencia en un mismo sujeto de vectores identitarios diversos y el establecimiento de las acciones propias para cada uno de esos vectores -en el caso analizado por Weltzien, únicamente dos: las propias del superhéroe y las propias del ciudadano ordinario- se determinan a través de los trajes. Para Weltzien, de hecho, ninguna identidad "real" precede a esos juegos de roles. Volviendo a la moda, idéntica opinión posee el sociólogo francés Frédéric Godart, para quien el vestido tiene a su cargo regular las "múltiples identidades, públicas o privadas, formales o informales, que se revelan a menudo contradictorias" (Godart, [2010] 2012, 30) pero que, no obstante, convergen en individuos particulares. En el caso de las poblaciones, por lo tanto, ocurre algo similar a lo descrito por Weltzien: si bien los trajes ordinarios no confieren superpoderes, sí confieren poderes: las diferentes identidades sociales asumidas a través de las prendas acaban regulando, de hecho, lo que cada sector de la población puede llevar a cabo en la vida cotidiana. En esta medida, el acceso diferencial a las prendas permite administrar las capacidades de actuación de los distintos sectores sociales que componen la población.

De hecho, unas ciertas tácticas policiales son desplegadas a fin de llevar a cabo dichos procesos regulatorios. Sin embargo, a diferencia de los dispositivos que disciplinan el género (los cuales se caracterizan por una vigilancia exhaustiva y una atención obsesiva a cada gesto), las biopolíticas vestimentarias operan con una relativa tolerancia. Como lo señala Foucault, los dispositivos de seguridad se caracterizan, contrariamente a los dispositivos disciplinarios, por una cierta permisividad, un cierto "dejar hacer" que a la postre se compensa con una gestión policial cuyo problema a nivel gubernamental ya no 
es "cómo decir (...) no, hasta donde (...) decirlo y con qué legitimidad", sino más bien "cómo decir sí" (Foucault, [2004] 2009, 97). En este sentido, y en tanto blanco del biopoder, la población exige una forma de gobierno capaz de crear pautas para que los cuerpos hagan ciertas cosas y las hagan en ciertos momentos -no sin una cierta (pseudo)espontaneidad prefabricada-, sin que medien de forma permanente la vigilancia y la coacción directas. De hecho, en opinión de Foucault, la biopolítica requiere epistémicamente hablando de la libertad como una condición para su ejercicio. ${ }^{32}$

En síntesis, y volviendo de nuevo a mi argumento central, considero que la gestión coordinada del conjunto de los rituales públicos se lleva a cabo a través de sistemas de marcación corporal que in/forman a los sujetos -a partir de su género pero también a partir de otros vectores identitarios- respecto de lo que se espera que hagan o no y del momento indicado o contraindicado para hacerlo. La vestimenta, por tanto, constituye a mi criterio una herramienta medular dentro de las labores de macrogestión de los comportamientos de la población, al punto de que, como lo indica la escritora británica, romper con ciertos mandatos vestimentarios supone, en algunos casos, romper con toda una trama de restricciones y estereotipos (Woolf, [1938] 1999, 200). El dispositivo vestimentario ceremonial tiene, pues, a su cargo, en última instancia, la regulación de los comportamientos de la población. El cometido de este dispositivo es, en fin, hacer que los cuerpos conozcan el itinerario de lo que Irving Goffman llama su "carrera moral" ([1963] 2010, 48-49). ${ }^{33}$

Los réditos últimos del dispositivo ceremonial en tanto dispositivo de control biopolítico, de este modo, consisten en hacer posible que en el marco de la vida de las poblaciones, y a partir de las marcas vestimentarias que cada cual lleva, todos sepan, con cierta "espontaneidad" y con un nivel relativamente bajo de coacción, lo que deben hacer y cómo hacerlo. En tal sentido, dicho dispositivo actúa creando dinámicas sociales que asocian las prendas con acciones y con los "permisos sociales" para llevarlas a cabo. En una palabra, lo que está en juego en relación con el dispositivo ceremonial es

\footnotetext{
${ }^{32}$ Sobre esta necesidad epistémica de la libertad como condición básica para el despliegue de estrategias biopolíticas, véase Foucault ([2004] 2009, 71).

${ }^{33}$ Una caracterización de la noción de "carrera moral" puede verse en Goffman ([1963] 2010, 48-49).
} 
la posibilidad de producir una especie de olfato moral para discernir situaciones, momentos y oportunidades de hacer, a partir del lugar social que las prendas asignan a los cuerpos dentro de grillas de inteligibilidad previamente definidas.

En este sentido, cabe concluir que la clasificación de las distintas identidades redunda en una administración social de las actividades y de los ritmos en que estas deben llevarse a cabo. A través de los sistemas policiales de clasificación, las vestimentas, al marcar los cuerpos y asignarles una identidad, distribuyen normativamente las actividades entre los sectores de la población, determinando quiénes pueden hacer qué, y cómo deben hacerlo. Creo adecuado sostener, por tanto, que las ceremonias a las que alude Woolf se extienden a toda la población no sin una cierta lógica coreográfica que determina, según el régimen de identificación de cada época histórica, la forma en que cada sector de la población debería que actuar.

\subsection{El dispositivo espacial}

Además de aspirar a controlar lo que los cuerpos llevan a cabo y a intentar codificar las relaciones sociales entre dichos cuerpos, las biopolíticas vestimentarias incluyen, por último, una preocupación por el espacio. Esto quiere decir que el vestido, además de influir en el accionar de los cuerpos y de jugar un papel dentro del establecimiento de parámetros de reconocibilidad intersubjetiva, también incide en la relación entre las poblaciones y el territorio en el que estas viven.

Según Foucault, el objetivo central de la policía es precisamente regir las relaciones entre los sujetos y el entorno que estos comparten, o en otras palabras, gobernar la población en tanto "conjunto de individuos con relaciones de coexistencia que los hacen vivir y habitar juntos" ([2004] 2009, 375). Así, pues, si los dispositivos anteriores generaban modos de subjetivación a través de la determinación de las acciones posibles e imposibles por un lado, y del establecimiento de códigos relacionales por otro, de lo que se trata en el caso del dispositivo espacial es de generar modos de subjetivación a través de políticas 
espaciales regulatorias de los tránsitos y los emplazamientos de los cuerpos a lo largo del territorio. El dispositivo espacial opera, en esta medida, configurando espacios y distribuyendo a los cuerpos dentro de ellos a través de los vestidos. En una palabra, el desafío de gobierno que intenta resolver el dispositivo espacial es qué cuerpos y a qué costo pueden aparecer en los diversos escenarios sociales.

Este dispositivo depende, por tanto, de clasificaciones corporales que tienen lugar a través de la vestimenta y el disciplinamiento del género. La socióloga argentina Leticia Sabsay destaca, desde una perspectiva útil para los efectos de lo que deseo sostener acá, el modo en que, en el marco de la configuración de políticas espaciales, se da una distribución primaria de los cuerpos dentro del territorio a partir del género $(2011,71)$. Por otro lado, como lo señalé en el capítulo anterior, el disciplinamiento de género utiliza como uno de sus dispositivos más importantes la moda. Partiendo de ambas premisas, me parece adecuado ver en el vestido un recurso biopolítico que estructura las relaciones entre los cuerpos y los territorios. Siguiendo a Sabsay, para quien el espacio es ya de por sí una relación social cuyas fronteras imaginarias están sexuadas desde un inicio (2011, 67-72), mi tesis es que las condiciones de "aparecibilidad" de los cuerpos -si se me permite tal expresión- vienen dadas por el modo en que estos son generizados a través de los vestidos. Las fronteras imaginarias, que para Sabsay designan una espacialización del imaginario sexual dentro de la cual el espacio configura el sexo al tiempo que el sexo configura el espacio $(2011,72)$ están, pues, directamente relacionadas, en mi opinión, con directrices normativas de carácter vestimentario.

Esto implica que mientras el espacio se recorta, ora con base en las restricciones, ora con base en las licencias de tránsito que se dan en él, asimismo, los cuerpos se subjetivan, en parte, o bien con base en los lugares a los que les está vedado entrar, o bien con base en los lugares a los que se les permite el ingreso. En otras palabras, mientras que los espacios se construyen imaginariamente a partir del tipo de cuerpos que pueden ocuparlos, los cuerpos, asimismo, se subjetivan con base en los lugares a los que, no sin cierta circularidad paradójica, tienen acceso. En ambos casos -sexualización del espacio y espacialización del sexo- la moda funciona como recurso material de gobierno. Así, al 
posibilitar o limitar el acceso de los cuerpos a ciertas zonas, las prendas no solo contribuyen a configurar esas zonas, sino que también coadyuvan a configurar a los sujetos con base en sus posibilidades de acceso y tránsito dentro de las mismas.

Pero al igual que en el caso de los dispositivos anteriores, esta gestión generizada del espacio también echa mano de ejes externos al género propiamente dicho. La regulación de los tránsitos, la creación de espacios exclusivos para ciertos sectores de la población, el diseño de zonas de tolerancia y de espacios que exigen un cierto aspecto corporal, dependen de clasificaciones sociales que, si bien parten del género, no se agotan en él. Sabsay habla en este sentido de una activación de fronteras morales $(2011,151)$ que, aún cuando dependen del género, incluyen diversas oposiciones normalizadoras, como por ejemplo las efectuadas entre trabajadoras sexuales y vecinos, o entre travestis y ciudadanos, o entre la comunidad -entendida como colectivo a proteger- y las minorías sexuales -entendidas como colectivos que amenazan el bien común-, o bien entre las familias y los individuos marginales como por ejemplo los vagabundos, los enfermos y los alcohólicos (Sabsay, 2011, 147-152). En todos estos casos un conjunto de políticas espaciales regulan, echando mano de la vestimenta y el aspecto, la relación entre la subjetividad y el territorio.

Esas políticas espaciales se despliegan fundamentalmente a través de dos mecanismos principales. Por un lado, a través del control de los emplazamientos y, por otro, a través de la administración de los desplazamientos. En un plano abstracto, "el emplazamiento es definido por las relaciones de vecindad entre puntos o elementos" (Foucault, [1994] 2010, 65). En su faceta policial, sin embargo, los emplazamientos se refieren a los recortes geológico/arquitectónicos que se avocan a configurar regiones dentro de un territorio. Según Foucault,

[...] el problema del (...) emplazamiento humano (...) es el problema de saber qué relaciones de vecindad, qué tipo de almacenamiento, de circulación, de localización, de clasificación de los elementos humanos deben ser preferentemente tenidos en cuenta en tal o cual situación para llegar a tal o cual fin (Foucault, [1994] 2010, 66). 
Estos procedimientos, que sin duda incluyen un diseño del espacio y una serie de artilugios ingenieriles, también se construyen, sin embargo, con base en un sujeto prototípico que será el que tendrá permitido el acceso a los espacios en cuestión. En esta medida, los sistemas vestimentarios de etiquetado diferencial a los que me referí antes siguiendo a Woolf revelan nuevas funciones pues además de su incidencia en la interacción social entre los distintos sectores de la población, también son útiles a la hora administrar desplazamientos - es decir, de determinar la capacidad de cada cuerpo para trasladarse dentro del territorio-, y a la hora de diferenciar y catalogar lugares. Así, las modas constituyen una forma de regular las relaciones entre los cuerpos, los tránsitos y los espacios, a través de prerrogativas sobre el aspecto que despliegan pautas policiales.

Algunos historiadores como Vigarello muestran el modo en que la producción de ciertos espacios como los sitios vacacionales -paradigmáticamente las costas- se dieron, en buena medida, justamente a través de la implantación de algunas modas cuyo acatamiento resultaba socialmente obligatorio para poder estar en ellos (Vigarello, [2004] 2009, 171172). Asimismo, para Baudelaire, la creación de las grandes metrópolis en tanto centros de producción y de concentración de las riquezas -el poeta piensa fundamentalmente en el caso de París- corrió de la mano del despliegue de un cierto glamour indumentario(Baudelaire, [1862] 1995, 130). El escritor uruguayo Roberto Echavarren, por su parte, también señala el caso de la ordenanza para las escuelas durante la dictadura militar en su país, "según la cual los estudiantes no podían entrar a las aulas si entre el cabello y el cuello de la camisa no mediaba un centímetro de nuca desnuda, lo cual medía un inspector, día por día, con una regla" (Echavarren, 2010, 93). De manera más general puede señalarse el caso de sitios nocturnos, instituciones públicas, o centros religiosos, lugares en los que históricamente se ha exigido un cierto protocolo vestimentario para poder ingresar y permanecer. En todos estos ejemplos, lo que está en juego es algo más que la simple diferencia entre la prohibición y el acceso a zonas o áreas específicas: mediante estas regulaciones, de hecho, se despliegan mecanismos de subjetivación que inciden en los parámetros de reconocimiento de los cuerpos. 
El vestido atiende, en este sentido, un problema de gobierno, a saber: ¿cómo controlar los desplazamientos y los emplazamientos de los cuerpos? Si, como he venido sosteniendo a lo largo de los capítulos anteriores, existe una cierta inestabilidad del sujeto y una cierta fragilidad de la norma que impiden hablar de los cuerpos como realidades dadas, el vestido resuelve prácticamente los desafíos que comporta la identificación de los individuos y el control de sus tránsitos. En otras palabras, a través de la vestimenta se intenta dotar de una identidad social a unos cuerpos cuyos desplazamientos, de otro modo, serían difícilmente controlables. Como no siempre es posible una regulación de los tránsitos con base en mecanismos más "seguros" (por ejemplo a través de documentos de identidad o de dispositivos biométricos, los cuales de todas maneras siguen siendo falibles) la vestimenta constituye un mecanismo de identificación cuya importancia resulta fundamental -dada su "inmediatez"- a la hora de desplegar las diversas estrategias de control territorial. De hecho, como lo indican About y Denis en su Historia de la identificación de las personas, la apariencia corporal permanece a lo largo de los diversos métodos de identificación policial como un elemento que permite regular estancias, salidas y tránsitos.

En una palabra, el dispositivo espacial tiene a su cargo regular, a través del vestido, la relación entre el cuerpo y el espacio. La indumentaria, en este sentido, se revela como un dispositivo que rige dónde y en qué condiciones los distintos cuerpos pueden aparecer. La administración de desplazamientos y detenciones, de entradas y salidas, así como la posibilidad de ciertos cuerpos de aparecer y de pertenecer a ciertos sitios, tiene en la moda, por lo tanto, un importante recurso de gobierno.

\subsection{Moda, disciplina y biopolítica: una síntesis provisional}

A partir de lo dicho hasta aquí queda en evidencia que las modas, en tanto formas de poder sobre el cuerpo, operan al menos en dos planos distintos a los señalados por la tradición de estudios sobre el vestido. Por un lado, al dotar los cuerpos singulares de una morfología que los torna socialmente reconocibles, la moda disciplina el género. Por otro 
lado, al gestionar políticas espaciales, conductas y paradigmas morales entre los distintos sectores de la población a partir de la asignación de identidades complejas (abarcadoras, como he insistido a lo largo de este capítulo no solo del género sino también de otros vectores más), la moda se erige, asimismo, como un mecanismo biopolítico.

Por ende, tal y como señalé al comienzo del capítulo, considero recomendable leer estos dos planos no de forma independiente, sino a partir de su entrecruzamiento. La distinción que he empleado entre los mismos, por tanto, es ante todo analítica. En la práctica, de hecho, los cuerpos despliegan un género al tiempo que son objeto de un control policial a nivel biopolítico. Por otra parte, la normalización del deseo a la que aludí al final del capítulo anterior también tiene una funcionalidad en ambos planos: la heterosexualidad obligatoria es, en efecto, tanto una prerrogativa biopolítica que posibilita la gestión de la población considerada en tanto especie, como una modalidad de castigo propia del disciplinamiento del género.

No obstante, pese al carácter analítico de la distinción entre la moda como dispositivo biopolítico y la moda en tanto mecanismo disciplinario, considero que el rol de dicha distinción es central si se quiere comprender los alcances de las artimañas de la moda. A través de dicho enfoque, de hecho, me parece que se perfila un tipo de análisis que, partiendo del género, no se agota en él, y que, en esa medida, permite comprender mejor una serie de mecanismos de poder cruzados que tienen lugar a partir de las modas.

Así, frente a la tendencia general en los estudios del vestido a limitarse a ver la moda como un mecanismo distintivo, creo que un análisis de la vestimenta en términos de bipoder permite ver en nuestro fenómeno, ante todo, un mecanismo de homologación. Si bien Simmel ya había advertido que la moda posee una doble función homologadora/individualizadora ([1905] 2008, 71-72), dicha polaridad a menudo se resuelve teóricamente hablando mediante un tipo de relación entre ambos elementos que, al centrarse -como lo indiqué en la primera parte de este texto- en el problema abstracto del consumo y de su origen, oblitera los efectos materiales que la moda, en tanto mecanismo de gobierno, ejerce sobre los cuerpos. De este modo, a través de la 
aproximación que he propuesto tanto en el presente capítulo como en el capítulo anterior, mi intención ha sido centrarme, antes que en el origen de la difusión de las modas, en el problema de sus efectos en el cuerpo.

No obstante, esta dimensión correctora, punitiva y policial que he atribuido hasta ahora a la moda se limita a analizar unilateralmente los efectos que esta posee sobre los cuerpos, cual si estos no reoperaran, a su vez, en las normas que los conforman. Una explicación más abarcadora del fenómeno de la moda, por ende, tendría que contemplar también este segundo aspecto. En una palabra, si bien la moda posee una relación con el control de los cuerpos y con su propia producción performativa, las normas vestimentarias no son infalibles y a menudo padecen fisuras y vacíos que posibilitan experiencias de agenciamiento por parte de diversos actores sociales. A esta segunda faceta del fenómeno vestimentario, pues, dedicaré mi atención en la tercera parte de este trabajo. 


\title{
TERCERA PARTE \\ Fisurar las artimañas
}

\author{
"los géneros no pueden ser ni verdaderos ni falsos, \\ ni reales ni aparentes, ni originales ni derivados. \\ No obstante, como portadores creibles de esos atributos, \\ los géneros también pueden volverse total y radicalmente increibles" \\ Butler, El género en disputa, 275 \\ "el cuerpo humano es el actor principal de todas las utopías" \\ Foucault, El cuerpo utópico, 13
}




\section{Capítulo 5. Estilo, subjetividad y crítica}

En los dos capítulos anteriores he examinado la moda a partir sus efectos en el cuerpo. Al proceder de tal manera he procurado evitar simultáneamente dos riesgos. Por un lado, caer en una visión esencialista del sujeto que cometiera el exceso de remitir reductivamente los complejos y multivectoriales problemas referidos a la moda a una antropología omniexplicativa. Mediante este primer desplazamiento mi intención ha sido intentar escapar a la idea de que el cuerpo y el sujeto preceden a los procesos de control involucrados en la moda. En primera instancia he querido evitar, pues, reducir la moda a un problema identitario relacionado a una subjetividad supuestamente dada con anterioridad a las relaciones sociales. Un segundo supuesto que he intentado sortear consiste en subsumir la moda dentro del problema general del consumo para así remitir, de nuevo reductivamente, la complejidad del fenómeno en cuestión a la naturaleza de sus mecanismos difusores. Allende esas perspectivas, mi intención ha sido sostener que si la moda se analiza como forma de poder - esto es, a partir de su ejercicio, pues como insistió Foucault, el poder no es una esencia que se posee sino una práctica que se ejecuta (Foucault, [2004] 2009, 16)- entonces se abre la posibilidad de reconsiderar qué pone en juego la vestimenta, cuáles son sus artimañas, sus impactos y sus réditos a nivel de control social.

Pero al abordar la moda de esta forma se corre un riesgo de otra naturaleza. Se da la impresión de que la moda constituye un sistema cerrado, sin posibilidades de ruptura. La dimensión biopolítico/disciplinaria que he atribuido a la moda, es decir, su carácter de biopoder, pareciera agotar el fenómeno vestimentario en un acatamiento coaccionado de normas que exceden por completo a los sujetos. En tal sentido, como lo han subrayado algunos críticos -véase a manera de ejemplo Berman ([1982] 1988, 24-25)-, denunciar las técnicas de disciplinamiento del cuerpo -en el caso del presente trabajo, las que tienen que ver con el cuerpo en/vestido por la moda- pareciera implicar necesariamente su pasividad. En síntesis, a partir de la argumentación de los capítulos anteriores podría alegarse que si bien el enfoque que he desplegado en torno a la moda podría alumbrar de 
una cierta manera su relación con el poder y el cuerpo, en la misma medida cierra el portillo a la hora de pensar una posible utilización crítica del vestido.

En este capítulo quisiera mostrar precisamente que el desplazamiento que he realizado en relación con las teorías discutidas en los dos capítulos iniciales no necesariamente conduce a una visión paralizante en cuanto a las posibilidades subversivas de la vestimenta. En las teorías mencionadas, por cierto, se suele cancelar cualquier tipo de vínculo entre crítica e indumentaria (me extenderé sobre la noción de crítica en un apartado posterior de este capítulo). Centradas como están en el tema de la emulación y en el problema de la difusión, estas teorías, de hecho, no pueden ver en el vestido sino el signo de una alienación consumista. Con excepción de Lipovetsky, quien realiza una cándida defensa de la moda en términos de reafirmación de la individualidad y de una exaltación consumista de lo singular (ignorando la dimensión disciplinaria y biopolítica que he caracterizado antes), la tradición filosófica que se ha ocupado de la moda no ve en esta más que un efecto y un reflejo del control de clase. En este sentido, dichos análisis se limitan, como lo apunta el escritor y crítico uruguayo Roberto Echavarren (2010), a dejar entrampada toda disidencia vestimentaria dentro de una dialéctica de la cooptación, tan ciega a los efectos de las discrepancias respecto de la normas vestimentarias, como a los efectos de su acatamiento. ${ }^{34}$

Lo lógico, si se quiere conceder algún potencial crítico a la vestimenta, sería, por ende, no tanto analizar las potencialidades contestatarias de la moda -si es que las tiene- sino centrarse en el problema del estilo -véase al respecto Echavarren $(2010,34)$, así como también Steimberg $(2001,32)-$. El estilo resulta, en efecto, un campo más fecundo a la hora de pensar en las disidencias vestimentarias, toda vez que apunta a un uso creativo del cuerpo y a una relación de mayor soltura entre este y las normas sociales. La noción de estilo aparece vinculada al cuerpo, en primera instancia, en la fenomenología de Maurice Merleau-Ponty. El filósofo francés, en efecto, realiza una lúcida teorización sobre el estilo -aunque ciertamente sucinta, dado su interés periférico en el tema- en la que el cuerpo aparece como un concepto fundamental y en el que los gestos y las formas

\footnotetext{
${ }^{34}$ Para un ejemplo prototípico de ese tipo de posición véase Heath y Potter ([2004] 2005).
} 
adquieren una densidad enteramente distinta a la propia de los cuerpos controlados por la moda que he descrito en la segunda parte del presente trabajo. Dado, sin embargo, que Merleau-Ponty no profundiza la relación del estilo con la vestimenta (aunque como mostraré sí ofrece algunas pistas de cómo se podría realizar dicha tarea), una segunda aproximación resulta significativa en el contexto de una reflexión a propósito de los estilos vestimentarios. Me refiero a la que efectúan los estudiosos de las subculturas juveniles de la Escuela de Birmingham. Inspirados en el estructuralismo de Lévi-Strauss, así como en la sociología norteamericana (especialmente en la Escuela de Chicago), dichos especialistas siguen, en efecto, un camino propio, centrándose fundamentalmente en la dimensión vestimentaria de los estilos juveniles. A partir de Merleau-Ponty y de la Escuela de Birmingham el estilo aparece entonces ligado por un lado al cuerpo y por otro a la vestimenta. Pero dado que mi interés, al hilo de las reflexiones de los capítulos anteriores, es pensar el estilo no como la manifestación de una subjetividad o un cuerpo dados sino como una instancia de subjetivación y de autoproducción corporal, en un tercer momento del capítulo abordaré el vínculo entre estilo y crítica a partir de las elaboraciones teóricas de Foucault. La crítica, desde este punto de vista, aparecerá entonces relacionada al estilo a la manera de un criterio ético que insufla formas subversivas al cuerpo vestido. Finalmente, estudiaré el modo en que Judith Butler plantea, en continuidad con lo sostenido por Foucault, una visión performativa del estilo en la que este posibilita la puesta en evidencia del carácter accidental de las normas que rigen tanto la vida corporal como el aspecto. Por último, toda vez que, como he intentado mostrar anteriormente, el género constituye un elemento central en lo referido a las artimañas de la moda, en el apartado final del presente capítulo me avoco a analizar la posibilidad de pensar los estilos como ejercicios capaces de cuestionar el binarismo de género.

Mi hipótesis en este capítulo es, por lo tanto, es que así como no hay un cuerpo desnudo o en estado puro que preceda a los cuerpos esculpidos por la moda, igualmente cierto es que la suerte de esos cuerpos, en el marco de los procesos de subjetivación, tampoco está echada de antemano. En otras palabras, considero que si el cuerpo, como lo señala el Le Breton, "no existe en estado natural [y] siempre está inserto en la trama del sentido" 
([1992] 2011, 33), entonces la moda, como cualquier otro proceso de subjetivación normalizante, es siempre un proceso abierto. En esa medida, si bien es cierto que la moda crea subjetividades y delinea cuerpos, también hay que decir que esos procesos nunca alcanzan a darse de forma acabada y absoluta. Precisamente en ese hiato entre los procesos formativos de subjetividad y su acatamiento social, es que, como mostraré, residen las posibilidades de la crítica estilística.

\subsection{Cuerpo y mundo: Merleau-Ponty y el asunto del estilo}

La reflexión en torno al estilo y su vínculo con la vida corporal irrumpe de una forma particularmente rica a partir de la obra del fenomenólogo francés Merleau-Ponty. Si bien Baudelaire, tal y como lo sostengo en el capítulo siguiente, había establecido ya en el siglo XIX un tipo de relación entre el cuerpo y los modos de presentarlo que podría ser conceptualizado en términos de estilo, en su obra, este último concepto aparece ligado todavía exclusivamente al mundo del arte -al igual que ocurre en la obra de Simmel ([1909] 2008). Maurice Merleau-Ponty, en cambio, construye una filosofía en la que el estilo desborda el ámbito artístico y se hace extensivo a la vida corporal.

Para Merleau-Ponty, como se sabe, el cuerpo no es un objeto entre otros. Contrariamente a lo aseverado por la psicología clásica y la fisiología moderna -a las cuales MerleauPonty critica- el filósofo subraya el hecho de que el cuerpo es un cuerpo vivo, siempre inmerso en una situacionalidad. Al mismo tiempo, el pensador francés se distancia de la tradición filosófica que afirma un cogito separado del cuerpo. En oposición a Descartes, Merleau-Ponty afirma, ciertamente, la imposibilidad de un pensamiento sin cuerpo ([1945] 2000, 219). La Fenomenología de la percepción ([1945] 2000), por tanto, constituye una obra que toma distancia tanto de las epistemologías que otorgan preeminencia al objeto por sobre el sujeto, como de aquellas que afirman la preponderancia del sujeto por sobre el objeto. 
En tal sentido, Merleau-Ponty defiende la centralidad del conjunto de tramas relacionales que se establecen entre el sujeto y su entorno. En otras palabras, sujeto y mundo se encuentran para el filósofo íntimamente ligados o, más aún, integrados en la existencia social. El cuerpo, en este contexto, resulta entonces fundamental en la medida en que constituye la instancia a partir de la cual la interacción entre el sujeto y el mundo se hacen posibles. Así, en las palabras del autor: "yo no estoy delante de mi cuerpo, estoy en mi cuerpo, o mejor, soy mi cuerpo" (Merleau-Ponty, [1945] 2000, 167). En tal sentido, según el filósofo, ni el cuerpo tiene preeminencia sobre el mundo, ni el mundo sobre el cuerpo ([1945] 2000, 219). Para Merleau-Ponty, al contrario, el cuerpo es aquello a partir de lo cual se abre la posibilidad para el sujeto de habitar el mundo.

En esta medida, como lo señalé antes, según el pensador francés no es posible dar cuenta del cuerpo como se daría cuenta de un objeto cualquiera. Dado que el cuerpo mantiene una relación viva con el mundo que rehúye las explicaciones supuestamente objetivas del mismo -como las ensayadas por el intelectualismo y el empirismo-, Merleau-Ponty asimila el cuerpo más bien a la obra de arte. Dicha comparación, por cierto, resulta fundamental en relación con el tema del estilo. Efectivamente, es en función de esta visión según la cual el cuerpo se asemeja a una obra de arte, que Merleau-Ponty incorpora en su análisis el asunto del estilo:

[...] lo que reúne las "sensaciones táctiles" de mi mano y las vincula a las percepciones visuales de la misma mano como a las percepciones de los demás segmentos del cuerpo, es un cierto estilo de los gestos de mi mano que implica cierto estilo de los movimientos de mis dedos y contribuye, por otro lado, a una cierta "andadura" de mi cuerpo. No es con el objeto físico que puede compararse el cuerpo, sino, más bien, con la obra de arte ([1945] 2000, 167).

La relación que el cuerpo establece con el mundo es, por tanto, una en la que los gestos y las acciones poseen una dimensión estilística que involucra una cierta creatividad o actividad (no obstante el hecho de que, como se verá en seguida, esa creatividad no se despliega sin que medien una serie de condicionamientos). Para Merleau-Ponty el estilo designa justamente una manera hasta cierto punto estetizada - en la medida en que se trata de un ejercicio que se asemeja al arte- de entablar una relación entre el propio cuerpo y el 
mundo. Dicha relación acusa, por otra parte, una cierta intencionalidad -husserliano sensu- que dota los movimientos de formas específicas. Esas formas, no obstante que difieren en el tiempo, poseen una unidad identificable. Para Merleau-Ponty, en este sentido, el estilo puede comprenderse como

[...] una cierta manera de tratar las situaciones que identifico o que comprendo en un individuo o en un escritor, recogiéndola por mi cuenta por una especie de mimetismo, incluso si no estoy en condiciones de definirla, y cuya definición, por correcta que pueda ser, nunca proporciona el equivalente exacto, ni tiene interés más que para cuantos han hecho ya un estilo. ([1945] 2000, 341).

Así pues, el estilo posee para Merleau-Ponty un cierto carácter inasible, mutable. En otras palabras, si bien para el filósofo el estilo posee una unidad, dicha unidad no debe confundirse con un método: un estilo no se agota en un procedimiento o conjunto de procedimientos (corporales, técnicos, estéticos, etc.); antes bien, el estilo es una manera de habitar el mundo y de intervenir la realidad que, si bien resulta reconocible, no por ello es definible a priori. El estilo, en esta medida, tiene que ver con desplegar una subjetividad propia, pues dado que "el mundo (...) tiene una envoltura de determinaciones objetivas, (...) también [tiene] fisuras, lagunas por donde las subjetividades se alojan en él o, mejor, que son las subjetividades mismas" (MerleauPonty, [1945] 2000, 347). Así, si para la fenomenología merleau-pontyana la apertura del mundo es posible en virtud de que tenemos un cuerpo, el estilo se refiere a las formas que reviste esa apertura.

El estilo, en esta medida, se inscribe asimismo en el marco de la tensión libertaddeterminismo. Según Merleau-Ponty, toda vez que el cuerpo posee una relación viva con el mundo, ningún vínculo causal predeterminado puede aplacar de entrada las posibilidades de acción del cuerpo. Por otra parte, el cuerpo habita el mundo desde un espesor histórico que condiciona sus acciones. En esta medida, echando mano de la tradición fenomenológica de la cual proviene, Merleau-Ponty incorpora la noción de proyecto para aludir a esa condición de la vida corporal a partir de la cual el ejercicio de la libertad se da siempre en un marco contextual que la circunscribe y condiciona. Según el autor, la libertad, por lo tanto, no está dada, sino que más bien está siempre por llevarse 
a cabo (Merleau-Ponty, [1945] 2000, 445). El estilo aparece, en este sentido, como una de las instancias a partir de las cuales se ejercita esa libertad corporal en el marco de un proyecto existencial. En otras palabras, si el cuerpo despliega temporalmente una libertad situada, el estilo tiene que ver con la gestualidad que asume el cuerpo en ese despliegue de libertad.

Ahora bien, si la filosofía de Merleau-Ponty se destaca por llevar el tema del estilo allende los confines del arte para así poder concatenarlo con el problema del cuerpo, queda por definir qué relación podría llevarse a cabo a partir de dicha filosofía entre el estilo y la vestimenta. Ciertamente Merleau-Ponty no aborda explícitamente dicha relación. No obstante, tal y como lo adelanté en el segundo capítulo, la relación que el filósofo establece entre las prendas y el cuerpo no es una relación de simple decoración tal y como ocurre dentro de las teorías clásicas de la moda-. Por el contrario, dado el vínculo consustancial del cuerpo con aquello que lo rodea, las prendas, en opinión de Merleau-Ponty, entran en relación con el cuerpo de una manera viva. De ahí que la prenda constituya para nuestro autor una suerte de anexo del cuerpo: esto es, un añadido que, sin embargo, pasa a tener una relación de unidad con él ([1945] 2000, 108). Desde este punto de vista, la Fenomenología de la percepción plantea una serie de ejemplos que permiten vincular las reflexiones merleau-pontyanas del estilo con el tema del vestido. El autor habla, v. gr., de casos que, como el del sombrero o el bastón, dan cuenta de esos procesos de in/corporación de artefactos vestimentarios:

[...] si quiero habituarme a un bastón, lo pruebo, toco algunos objetos y, al cabo de un tiempo, lo tengo "por la mano", veo qué objetos están al alcance de mi bastón y la distancia objetiva del fin por lograr. Los lugares del espacio no se definen como posiciones objetivas respecto de la posición objetiva de nuestro cuerpo, sino que inscriben alrededor de nosotros el alcance variable de nuestras miras o de nuestros gestos. Habituarse a un sombrero (...) o a un bastón, es instalarse en ellos o, inversamente, hacerlos participar en la voluminosidad del propio cuerpo (Merleau-Ponty, [1945] 2000, 160-161).

La relación entre cuerpo y prenda es para Merleau-Ponty, así, una relación viva. Al in/corporar la prenda, de hecho, el sujeto es capaz, tal y como lo sugiere el pasaje anterior, de ganar un poder, en la medida en que el bastón, el sombrero, o cualquiera que 
fuere la prenda en cuestión, pueden llegar a ensanchar volúmenes así como a sumar capacidades. En esta medida, Merleau-Ponty da cuenta del "poder que tenemos de dilatar nuestro ser-en-el-mundo o de cambiar la existencia anexándonos nuevos instrumentos" ([1945] 2000, 161). Se trata de una visión prostética de la prenda similar a la que describí en el capítulo dos: si la prenda puede ensanchar las posibilidades del cuerpo, ello implica que el vestido es un dispositivo técnico capaz de dotar de nuevas funciones al mismo. A pesar de ello, Merleau-Ponty no vincula el tema de ese poder de dilatación propio de las prendas con el tema del estilo (en razón, claro está, de que no es el objetivo de su estudio). Lamentablemente, tampoco en teorías de la moda más recientes se ha explotado ese posible vínculo. De hecho, con excepción de la feminista australiana Wendy Parkins (véase la segunda sección del capítulo siguiente) y de Entwistle y su aplicación de Merleau-Ponty dirigida a subrayar la importancia de pensar "el vestir como una experiencia corpórea" (Entwistle, 2000, 18), quienes se ocupan del tema del vestido pocas veces recurren a las sugerentes reflexiones merleau-pontyanas sobre el estilo.

Por el contrario, las reflexiones más difundidas en torno al vínculo entre estilo y vestimenta provienen de los estudios realizados por los teóricos de las subculturas juveniles. Dentro de dicho enfoque, como mostraré a continuación, priva más bien una comprensión filosófica del estilo que parte de la sociología alemana y norteamericana que de la fenomenología. A partir de dichos estudios tendrá lugar, así, un importante desplazamiento, en la medida en que en ellos se plasma un interés por estudiar directamente la relación entre estilo y prenda; pero se trata también de un desplazamiento que pierde algo del terreno ganado por Merleau-Ponty, toda vez que olvida anclar el potencial subversivo del estilo en el terreno de lo corporal.

\subsection{Los estilos juveniles: la Escuela de Birmingham y la vestimenta}

Los estudios sobre las subculturas juveniles alcanzan su más acabada formulación dentro de la Escuela de Birmingham y su análisis de los grupos juveniles dentro del contexto inglés de la posguerra -sobre los objetivos teóricos de la Escuela de Birmingham véase 
Clarke, Hall, Jefferson y Roberts (2006)-. Dichos estudios, fundamentalmente influenciados por la tradición de la sociología alemana (Webber, Durkheim, Mauss y Levi-Strauss, entre otros), se inscriben asimismo dentro de los esfuerzos de la sociología norteamericana por comprender los comportamientos "desviados" -sobre la recepción y combinación de parte de la Escuela de Birmingham de esas dos matrices analíticas véase la introducción de Hall y Jefferson al emblemático volumen colectivo Resistance through Rituals: youth subcultures in post-war Britain (Hall y Jefferson, 2006, xix)-. A partir de ese interés hacia los grupos "desviados", los estudios de la Escuela de Birmingham utilizan un criterio de ingreso al problema del estilo enteramente distinto $-\mathrm{y}$ en cierto sentido menos preciso filosóficamente hablando- al de la fenomenología de MerleauPonty. No obstante, como mostraré en este apartado, dichos estudios permiten avanzar hasta cierto punto en la comprensión del vínculo existente entre las prendas y el estilo.

Las primeras elaboraciones en torno a las subculturas juveniles tienen sus raíces, tal y como lo señala el antropólogo catalán Carlos Feixa, en el estructural-funcionalismo de Parsons (Feixa, 1999 46-56). En rigor, sin embargo, la Escuela de Birmingham tiene en Howard Becker su principal inspiración teórica -véase al respecto la introducción de Hall y Jefferson antes aludida así como también el artículo de los teóricos de la Escuela de Birmingham Pearson y Twohig citado en la bibliografía-. Becker, quien a diferencia de Parsons intenta pensar la "desviación" no en términos de una disfunción social sino más bien en términos de una práctica políticamente regulada y dirigida a estigmatizar a quienes desatienden las normas (Becker, [1963], 2012, 26-27), influencia significativamente a la Escuela de Birmingham no solo en razón de su visión empática de los grupos que estudia, sino también en función del hecho de que pone el acento en el estudio del sentido producido al interior de esos grupos de desviados $-\mathfrak{u}$ outsiders, como los denomina el autor-. En tal sentido, el sociólogo norteamericano introduce la idea de que alrededor de la "desviación" se alcanzan a formar culturas alternativas que producen tramas de significados. La tesis de que los grupos "desviados" crean una cultura aparte de la cultura normal será de hecho vital para la ulterior reflexión de los fundadores de los estudios culturales de la Escuela de Birmingham acerca del estilo; para Becker, en efecto, 
los outsiders no se limitan a quedar por fuera de la cultura dominante, sino que también crean sus propios significados culturales.

Becker, sin embargo, apenas y presta atención al tema del estilo. Si bien en sus trabajos de campo el autor hace referencia a la importancia de considerar los estilos de vida de los outsiders (Becker, [1963], 2012, 99), su interés se centra fundamentalmente en la descripción etnográfica de las prácticas y percepciones de los individuos que conforman dichos grupos antes que en su aspecto corporal. En el contexto de su recepción inglesa por parte de los estudiosos de la Escuela de Birmingham, en cambio, el asunto de la indumentaria y su relación con el estilo será objeto de una atención pormenorizada. Dicha recepción, en efecto, se encuentra marcada por un marcado interés en estudiar el tema del estilo vestimentario de las culturas juveniles inglesas, entendido como una forma de resistencia simbólica ante el mundo adulto y burgués.

Para la Escuela de Birmingham, las subculturas juveniles deben entenderse como una reacción de clase propia de un grupo etáreo particular que procura dar una respuesta a su situación de subordinación. En tal sentido, los subgrupos juveniles ya no hacen referencia únicamente a grupos "desviados" de y por las normas, sino también a colectivos con una cierta conciencia de clase que intentan articular rituales de resistencia. Dentro de dichos intentos, los estilos y las prendas ocupan un lugar fundamental: "[las subculturas juveniles] adoptan y adaptan objetos materiales -bienes y posesiones- y los reorganizan dentro de 'estilos' distintivos" (Clarke, Hall, Jefferson y Roberts, 2006, 35; traducción propia). En tal sentido, las prendas forman parte de un conjunto de elementos que permiten a las subculturas plantear alternativas simbólicas a los desafíos que comportan su situación de subordinación.

Para Clarke, el principal especialista en torno al tema del estilo dentro de la Escuela de Birmingham, el estilo "no puede aislarse de la estructura de grupo, de su posición, sus relaciones, sus prácticas y su auto-conciencia" (2006, 148; traducción propia). Echando mano del estructuralismo de Lévi-Strauss, los autores de la Escuela Birmingham plantean, así, los procesos de generación estilística como puestas en marcha de 
procedimientos de bricolage, es decir, como prácticas de selección de signos vestimentarios ya en circulación pero con una voluntad de recontextualización y reordenamiento que guarda relación con una serie de prácticas e ideas políticas (Clarke, 2006, 148). En este sentido, la posibilidad de un uso contrahegemónico de la vestimenta involucra para los autores mencionados, ante todo, una disidencia semiótica -lo cual implica, como lo señalé antes, un retroceso con respecto a Merleau-Ponty, quien había defendido ya, a mi juicio atinadamente, la dimensión propiamente corporal de los estilos; para una comprensión posemiótica del cuerpo véase asimismo Nancy ([2000] 2010, 22)-.

Siguiendo a Barthes, los autores de la Escuela de Birmingham intentan dar cuenta, de este modo, de los sistemas sígnicos estilizados de las subculturas juveniles (Clarke, Hall, Jefferson y Roberts, 2006, 42). Así, en el interior de los análisis en cuestión, la moda funciona como trasfondo semiótico necesario, pues el estilo recontextualiza los elementos que esta pone a circular:

[...] nosotros consideramos los estilos "no oficiales" recientemente actuales, en los que el núcleo estilístico (...) puede ser localizado en la expresión de una oposición en parte negociada a los valores de la mayoría de la sociedad. Sin embargo, esto recuerda una forma básica de discurso hacia la cual el bricoleur subcultural debe referirse si quiere que su mensaje sea comunicado. En este caso, ese discurso es el de la moda (Clarke, 2006, 149; traducción propia).

A contramano de análisis como los de Simmel o Veblen, la Escuela de Birmingham propone, así, una relación en la que no solo la moda opera sobre el cuerpo sino también a la inversa. Según la posición que había sido defendida otrora por Simmel, en efecto,

[...] no es (...) la hostilidad a la moda menor testimonio del poder que sobre nosotros ejerce la tendencia social. En forma positiva o negativa, nos hace sus súbditos. La antimoda preconcebida se comporta ante las cosas lo mismo que el frenético de la moda (...). Hasta puede ocurrir que en círculos enteros, dentro de una amplia sociedad, llegue a ser moda ir contra la moda ([1905] 2008, 83-83).

A partir de este esquema -el cual, por lo demás, sentó las bases de una posición común aún recientemente entre los teóricos de la moda; véase a manera de ejemplo el libro Rebelarse vende, de Heath y Potter (2004] 2005)- se considera que el vestido carece de 
toda capacidad ruptural toda vez que las dinámicas consumistas son capaces de fagocitar cualquier diferencia reintroduciéndola en los circuitos mercantiles a través del consumo. Para la Escuela de Birmingham, en cambio, los estilos tienen capacidad de contraataque. Según Clarke, en efecto, si bien la moda des-contextualiza a través del mercado el uso subversivo que las subculturas juveniles hacen de las prendas, dichas subculturas, a su vez, desarrollan estilos a través de la apropiación re-contextualizada de algunas prendas de moda. Esto es: mientras que el estilo selecciona unas ciertas prendas y las utiliza en función de su pertinencia a la hora de comunicar una determinada identidad subcultural (fenómeno al cual Clarke alude en términos de "difusión" [difussion]), la moda abstrae la prenda de su uso politizado convirtiéndola en una mercancía apta para un consumo desprovisto de todo contenido subversivo (a lo cual Clarke hace referencia en términos de "difuminación" [defusion]). De este modo, según los teóricos de la Escuela de Birmingham, mientras que el estilo utiliza los signos de la moda y los desplaza a un contexto semiótico en el que dichos signos pasan a tener un significado subversivo (difussion), la moda, a su vez, reinserta los signos estilísticos y su contenido político dentro de un consumo de masas en el cual estos pierden su capacidad contestataria (defusion). Dicha dialéctica, sin embargo, no termina, a diferencia de lo planteado por Simmel, con la inevitable victoria de la moda: los estilos, por el contrario, constituyen formas de resistencia que envuelven significados políticos. En palabras de Clarke, por lo tanto, existe una "relativa apertura de los procesos de apropiación estilística" (2006, 155; traducción propia).

No obstante, según los teóricos de la Escuela de Birmingham, los estilos también constituyen esfuerzos limitados. A partir de la tesis de que las disidencias estilísticas constituyen una suerte de solución imaginaria para una problemática real que las subculturas juveniles no logran trascender - problemática que viene dada por su posición estructural de clase- (Clarke, Hall, Jefferson y Roberts, 2006, 25), los teóricos de la Escuela de Birmingham hablan de las resistencias estilísticas como "resoluciones mágicas". Por dicha noción, los autores en cuestión hacen referencia 
[...] no solamente al intento de abordar los problemas derivados de las contradicciones de clase, sino también al intento de solucionar dichas contradicciones, intento que, de forma crucial, no soporta sus soluciones sobre el terreno real en el que las contradicciones en sí mismas tienen lugar, por lo cual dejan de representar una alternativa, una solución potencialmente contrahegemónica (Clarke, 2006, 159; traducción propia).

Así, pese al moderado optimismo de la Escuela de Birmingham con respecto al esquema simmeliano, dentro de su perspectiva el estilo sigue teniendo en la moda y la expansión comercial de las tendencias su frontera última: el estilo remite, de hecho, al ámbito de la resistencia reactiva y no al de la rebelión propositiva (Corrigan y Frith, 2006, 201). En otras palabras, el estilo viene a ser una especie de recurso sublimatorio anclado todavía en una dialéctica de la distinción que disimula la posición de clase de las subculturas juveniles, pero que no trasciende dicha posición.

Con el concepto de "resolución mágica", la Escuela de Birmingham plantea un importante problema en relación con el tema de la presente investigación, a saber: ¿cuál es el criterio políticamente definitorio del estilo? $\mathrm{O}$ en otras palabras: ¿hasta qué punto un estilo puede llegar a despegarse de la moda?, ¿qué hace que un estilo resulte verdaderamente perturbador de las normas que se intentan imponer socialmente mediante la moda?

No obstante, pese a que la problemática puesta de relieve por parte de dichos autores es de suyo relevante, no es posible decir lo mismo de los términos en que se realiza dicha problematización. Al desconocer la elaboración merleau-pontyana del estilo, la Escuela de Birmingham, de hecho, lleva a cabo un repliegue en las teorías clásicas de la moda. Por un lado, dentro del enfoque de los autores ingleses, la moda aparece todavía entrampada dentro de una dialéctica del consumo que soslaya la relación del estilo con el cuerpo; por otro lado, al partir de la semiología barthesiana, dichos autores consideran las disidencias estilísticas como estrategias meramente semióticas, con lo cual las capacidades contrahegemónicas del estilo quedan referidas a un ámbito simbólico y no material -respecto de esta segunda crítica véase Entwistle ([2000] 2002, 15), así como mis propias críticas al enfoque semiológico planteadas en el primer capítulo-. En otras 
palabras, el análisis del Escuela de Birmingham oblitera la dimensión propiamente corporal del estilo, haciendo de la prenda únicamente un recurso semiótico fácilmente cooptable por las dinámicas de consumo.

Con todo, creo que la Escuela de Birmingham plantea una aproximación interesante a la hora de pensar la dimensión estratégica del vestido y su vínculo con el estilo. Particularmente, considero útil la relación antagónica que dichos autores establecen entre el poder social y los estilos, así como su visión de la prenda como un insumo para la resistencia. Por lo demás, la Escuela de Birmingham introduce la importante interrogante respecto de cuáles podrían ser los criterios políticamente definitorios de los estilos juveniles. De hecho, por fuera del campo de las subculturas juveniles inglesas, la interrogante sigue siendo pertinente para los efectos del presente trabajo: ¿cómo diferenciar los estilos de las artimañas de la moda?

Para enfrentar dicho problema considero, no obstante, que podría resultar conveniente ir allende la teoría de la Escuela de Birmingham. Concretamente creo adecuado, en orden a pensar el estilo como ejercicio subjetivante $-\mathrm{y}$ no como el despliegue de una subjetividad previamente dada-, recurrir a Foucault y al vínculo que dicho autor establece entre el estilo y la crítica. Mediante dicho vínculo, el estilo encontrará un norte ético que desborda lo semiótico y que permitirá devolver las virtudes estilísticas de las prendas al ámbito de lo propiamente corporal.

\subsection{Subjetividad y crítica: la ética foucaultiana y la estilística de la existencia}

Si bien Foucault no se ocupa de crear una teoría del estilo propiamente dicha, sus obras sí contienen una reflexión a propósito del modo en que los cuerpos entablan diversos modos de relación ética con las normas sociales. En tal sentido, para el filósofo francés la relación entre el cuerpo y el poder, aún cuando puede estar signada por las normas, también puede abarcar ejercicios alternativos capaces de estilizar el cuerpo e insuflarle formas críticas allende las formas dóciles producidas por el biopoder. 
La relación entre el estilo y la crítica aparece en las reflexiones foucaultianas emparentada en un inicio a procesos de subjetivación en los cuales el cuerpo asume una morfología indócil. Sin embargo, a diferencia del carácter estrictamente semiótico de los análisis estilísticos de la Escuela de Birmingham, la aproximación posestructuralista de Foucault retorna al planteamiento de Merleau-Ponty -aunque de forma implícita, como suele ocurrir en sus escritos- para analizar la posibilidad de pensar el estilo como una práctica corporal. A diferencia de Merleau-Ponty, sin embargo, lo central para Foucault será anclar el estilo en la crítica, entendida esta última como criterio ético orientador que, aunque mutable, se caracteriza por la posibilidad que ofrece de desafiar las normas corporales.

Foucault introduce el tema de la crítica, en primera instancia, en un terreno ajeno al estilo. Es, en efecto, a partir del interés foucaultiano en la pregunta kantiana por la Aufklärung que el concepto de crítica aparece en el corpus del pensador francés. Para Foucault, a partir de Kant es posible plantear la crítica en vínculo estrecho con la historia. Desde esa perspectiva, la crítica se refiere a una labor de interrogación en relación con el propio presente. En otras palabras, para Foucault la crítica está ligada a una ontología de nostros mismos, o lo que es lo mismo, a una interrogación histórica a propósito del modo en que hemos llegado a constituirnos como los sujetos que somos (Foucault, [2008] 2010, 39). Así, según el filósofo, la crítica puede definirse, grosso modo, como una actitud de cuestionamiento hacia el modo en que la historia ha fijado los parámetros a partir de los cuales se hacen posibles las subjetividades. La crítica, en suma, "es el análisis de los límites y la reflexión sobre ellos" ([1984] 2010c, 986), especialmente de aquellos relacionados con los modos históricos de pensar la subjetividad.

No obstante, dentro de las reflexiones de sus últimos trabajos en torno al pensamiento antigüo, Foucault vuelve sobre el asunto de la crítica y la vincula con el tema del cuerpo y el estilo. En su análisis sobre los regímenes de subjetivación griegos y latinos Foucault plantea, en efecto, una sugerente comprensión de la ética vinculada al trabajo crítico del sujeto sobre su propio cuerpo. Para Foucault, la ética no se refiere de manera limitada al 
acatamiento de unas determinadas prescripciones morales, sino que involucra un uso estilizado del cuerpo (Foucault, [2001] 2009, 402). Dentro de este enfoque, la obediencia u observancia de las reglas constituye, de hecho, únicamente un aspecto del fenómeno moral. Allende este plano, al que el filósofo denomina la "moralidad de los comportamientos", Foucault propone, en efecto, una comprensión de lo moral en la que es igualmente relevante la "determinación de la sustancia ética", el "modo de sujeción", el "trabajo ético" y la "teleología del sujeto moral". ${ }^{35}$ A partir de estos distintos aspectos del fenómeno moral, Foucault se desplaza de la cuestión de las normas y de su poder para intervenir el cuerpo hacia la cuestión del ethos. El ethos hace referencia, según Foucault, precisamente al modo en que las éticas cuajan en una serie de comportamientos estilizados, portadores de una visión de mundo y resultantes de un trabajo ético del sujeto sobre sí mismo. En referencia al mundo antiguo, Foucault señala que "el ethos era un modo de ser del sujeto y una manera de proceder que resultaban visibles para los otros. El ethos de alguien se reflejaba a través de su vestir, de su aspecto, de su forma de andar, de la calma con la que respondía a los sujetos, etc." (Foucault, [1984] 2010b, 1032). Al poner de relieve la importancia del ethos por sobre la simple observancia o inobservancia de las normas, Foucault encuentra un punto de fuga a partir del cual pensar en prácticas corporales no disciplinadas: en la ética, el asunto de cómo se acatan las normas y de qué sucede con los individuos cuando lo hacen, es de hecho tan relevante como la propia observancia o inobservancia de una normativa determinada. En esa medida, la crítica está emparentada con la ética, o aún más, la crítica es concebida como una forma de virtud vinculada a las formas de gobierno de sí mismo (Foucault, [1990] 1995, 6). En la pregunta por cómo queremos ser gobernados está implícita, así, la tesis de que no existe una sola forma de gobierno, y es por esa misma razón que, de hecho, la labor genealógica muestra las distintas gubernamentalidades a lo largo de la historia y las diversas experiencias de subjetivación derivadas de ellas (Foucault, [2008] 2010, 85).

\footnotetext{
${ }^{35}$ La "determinación de la sustancia ética" designa, según Foucault, el modo en que los individuos deben trabajar con tal o cual parte de sí mismos en la medida en que esas partes constituyen la materia principal de su comportamiento moral. El "modo de sujeción", por otro lado, hace alusión a la manera en que los individuos entablan relación con unas determinadas reglas y se reconocen interpelados para ponerlas en práctica. El "trabajo ético" se refiere a lo que cada individuo hace consigo mismo para intentar transformarse en sujeto moral de su conducta. La "teleología del sujeto moral", por último, hace referencia al fin moral o modo de ser al que tienden las acciones de un individuo. Para una exposición detallada de este método de estudio de lo moral véase Foucault ([1984] 2003, 26-33).
} 
A partir de esta descomposición analítica del fenómeno moral, Foucault estudia la ética antigua y arriba a la conclusión de que en la experiencia grecolatina de lo moral existe la prerrogativa de hacer de la propia vida y del propio cuerpo una obra de arte. Para Foucault, la Antigüedad está, en efecto, marcada por una "una búsqueda obstinada de cierto estilo de existencia" (Foucault, [1984] 2010a, 1018-1019) en la que el cuerpo es objeto de una serie de maniobras éticas que involucran el acicalamiento y la indumentaria. En el último de sus seminarios del Collège de France Foucault se refiere en este mismo sentido a la posibilidad de conceptualizar el cuerpo como locus de un cierto virtuosismo o de una cierta crítica bajo la forma del estilo. Vista a través del prisma de la ética antigua, la crítica kantiana asume así un nuevo cariz: "la crítica será el arte de la inservidumbre voluntaria, el de la indocilidad reflexiva" (Foucault, [1990] 1995, 8). De lo que se trata, por ende, es de entender la labor ética del sujeto sobre su propio cuerpo como una labor a la vez ética y estética cuyo fin es convertir la propia existencia en una obra de arte crítica y portadora de verdad (nótese la evidente similitud de este punto del enfoque foucaultiano con la perspectiva de Merleau-Ponty). No obstante, como mostraré a continuación, no se trata de una verdad entendida por fuera de la vida, sino al contrario, de una verdad que surge de ella.

Para efectos de explicar esta última cuestión, Foucault introduce el concepto de "aleturgia". La "aleturgia", según Foucault, designa un tipo de producción corporal (tanto verbal como no verbal) en la que el cuerpo (el autor se refiere especialmente al cuerpo del cínico) deviene la "plástica misma de la verdad, [pues existe] una relación no sólo de conformidad de conducta, sino de conformidad física, de conformidad, en cierto modo, corporal entre el cínico y la verdad" ([2009] 2010a, 320). Mediante este ejemplo histórico, Foucault relaciona el cuerpo estilizado con la crítica: si la "aleturgia" es una cierta teatralización de la verdad, el cuerpo virtuoso es el que se encarga de hacer entrar dicha verdad en escena mediante una expresión plástica -aunque no restrictivamente plástica- que despliega una crítica política. "Verdad" se refiere en este contexto, justamente, a una operación vinculada con la crítica tal y como Foucault la entiende a partir de Kant; es decir, como el despliegue de un ethos que se afianza en una ontología 
histórica del presente. La verdad, por tanto, ya no designa acá un sentido impuesto al cuerpo como ocurría en las disciplinas. Se trata, por el contrario, de una verdad que surge de un trabajo crítico con el cuerpo, y de una oposición al poder, de una estilística de la existencia que busca oponer a los discursos de poder, su verdad ocluida. En este contexto, el estilo se presenta como una instancia de autoproducción corporal en el que la crítica permite al sujeto entablar un tipo de relación consigo mismo marcada por su oposición al poder. En otras palabras, el estilo aparece acá no ya como un ejercicio de significación de un sujeto previamente constituido -como ocurría en los análisis de la Escuela de Birmingham-, sino más bien como una práctica subjetivante, es decir, como una instancia de emergencia de subjetividad crítica.

En El coraje de la verdad ([2009] 2010a) Foucault introduce una segunda categoría igualmente pertinente en el contexto de la relación entre estilo y crítica. Me refiero al concepto griego de parrhesía. La parrhesía, al igual que la "aleturgia", tiene que ver con la tesis foucaultiana según la cual la verdad de la crítica es un acto mediante el cual, quien dice la verdad, la produce en el acto mismo de la enunciación. De este modo, el parrhesiasta es aquel que, al presentarse a sí mismo como poseedor de un decir veraz y al confrontar a los demás con su palabra, su cuerpo, su aspecto y su modo de vida, despliega una verdad que coincide con el acto corporal de su enunciación. En esta medida, la parrhesía es definida por Foucault, en sentido amplio, como un hablar franco o verdadero (Foucault, [2008] 2010, 59). Sin embargo, cuando el filósofo sigue el itinerario de la preocupación antigua por el decir verdadero señala que la parrhesía involucra desde un uso cívico ([2009] 2010a) y una utilización de este mismo concepto en el marco de la relación entre el individuo y su director de conciencia ([2001] 2009), hasta el uso propiamente crítico que el cinismo atribuyó a dicha noción ([2009] 2010a). Es dentro de esta última concepción filosófica donde la parrhesía surge como consecuencia de un modo de vida filosófico (bios philosophikós). En la parrhesía, entendida como acto enmarcado dentro de una vida filosófica, la verdad es algo que el sujeto dice de sí mismo (y no ya, como en el biopoder, algo que se dice sobre el sujeto), a partir de un trabajo ético realizado por medio de una serie de técnicas que lo hacen dar con verdades situadas: verdades sobre los individuos y las situaciones en las que están inmersos. Así, el 
parrhesiasta establece un modo de veridicción completamente particular: no se trata, la suya, de una verdad sobre el ser o la naturaleza; tampoco de una verdad profética o de una verdad entendida como capacidad de ejecución de un oficio. La verdad del parrhesiasta es una que surge más bien como consecuencia de un ethos creador. En esta medida, el cuerpo crítico o virtuoso es aquel que despliega un ethos confrontador que emerge de la propia vida. El estilo, desde esta perspectiva, deviene un modo de dar forma al cuerpo a partir de una crítica confrontativa que surge del trabajo ético de sí.

En El uso de los placeres ([1984] 2003) y La inquietud de sí ([1984] 2004) Foucault, por otra parte, proporciona algunos ejemplos de prácticas de estilo como las recién descritas en una relación estrecha con las prendas. Así, el filósofo se refiere, v. gr., a la esposa que según Jenofonte sabe que "la ropa (...) tiene una propiedad y una elegancia que la distinguen" ([1984] 2003, 151), por lo cual se viste haciendo patente su autodominio y su capacidad de gobernar a otros. También el filósofo hace alusión al enfrentamiento durante la época helenística entre una aristocracia empeñada en "fijar su identidad del lado de su estatuto (...) por medio de todo un conjunto de signos y de marcas que corresponden a la actitud corporal" y quienes tratan de "constituirse y de reconocerse como sujeto[s] de [su]s propias acciones, no a través de un sistema de signos que marquen el poder sobre los demás, sino a través de una relación tan independiente como sea posible del estatuto y de sus formas exteriores" ([1984] 2004, 83). De mismo modo, Foucault se refiere al Antonino referido por Marco Aurelio, quien a través del uso moderado "de la ropa, del dormir y los muchachos" ([1984] 2004, 83) buscaba entablar un tipo de relación consigo mismo que le proporcionara serenidad. Se trata de ejemplos en los que se trasluce la dimensión estilística involucrada en los procesos de subjetivación: mediante un trabajo ético sobre sí mismos, estos personajes dan cuenta de la posibilidad histórica de trabajar con el propio cuerpo vestido de modo que este despliegue un ethos capaz de algo más que simplemente atenerse a las normas corporales. No obstante, como mostraré en el próximo capítulo, no se trata de casos referidos exclusivamente a la Antigüedad: el estilo no constituye en sentido alguno un ejercicio exclusivo de una época en particular, sino un tipo de relación ética que es posible detectar 
en varios contextos históricos -véase al respecto Foucault ([1983] 2013, 146-147) así como también Castro (2011, 145-146)-.

Dentro de la concepción foucaultiana de la ética, por lo tanto, el estilo aparece ligado, por un lado, a un éthos cuestionador y crítico, y por otro, a los modos de trabajar el cuerpo por ejemplo mediante el vestido- en aras de que despliegue dicho éthos. La estilística de la existencia foucaultiana está ligada, en este sentido, a un trabajo del individuo sobre su propio cuerpo cuyo fin es convertir la vida en una obra de arte. Este trabajo sin embargo, no lo realiza un sujeto dado con anterioridad al gesto estilístico; por el contrario, es el propio gesto estilístico el que permite a los cuerpos críticos hacerse con una subjetividad. Es esta misma línea teórica la que, como mostraré a continuación, Judith Butler desarrolla en vinculación con su teoría sobre la performatividad. Mediante la aproximación de Butler, sin embargo, el estilo acabará no únicamente emparentado con la crítica y el trabajo de sí, sino también con la negociación de los parámetros ontológicos que determinan lo que se considera como cuerpo y lo que no.

\subsection{La performatividad butleriana y el estilo: sobre la posibilidad de ensanchar los parámetros de inteligibilidad corpórea}

Siguiendo la perspectiva foucaultiana Judith Butler relaciona desde su propio punto de vista el estilo con la crítica corporal. Para Butler, como lo he mencionado antes, las identidades surgen como resultado de procedimientos de poder que otorgan una estabilidad ficcional a una serie de actuaciones performativas. Es en virtud de esa inestabilidad constituva del sujeto que Butler considera posible la irrupción de una crítica corporal de los parámetros ontológicos que rigen la existencia social.

Como lo señalé en el capítulo 2, Butler sostiene que las subjetividades esencialistas

surgen de operaciones políticas y ontológicas que pretenden asignar al cuerpo y a la psique una estabilidad, la cual, en realidad, se construye a través de una modelación performativa del cuerpo sostenida a lo largo del tiempo. Los cuerpos generizados, desde 
esta perspectiva, citan performativamente las normas, y es a partir de dicha citación que las mismas se materializan (Butler, [1993] 2008, 38). No obstante que el performativo posee una dimensión en principio retórica u ontológica, los cuerpos, en efecto, se construyen de un modo performativo en virtud de que la materialidad de los mismos está vinculada a las grillas de inteligibilidad que los tornan legibles. Toda vez que esa materialización de las normas depende de una reiteración temporal cuyo escenario es el cuerpo, Butler habla, por tanto, de la performatividad como una labor con un cierto contenido estilístico.

Partiendo de una relectura beauvoireana de la fenomenología de Merleau-Ponty, Butler señala en este sentido que el cuerpo generizado constituye "una identidad instituida por una repetición estilizada de actos [stylized repetitions of acts]" ([1990] 1998, 297). Para Butler, al igual que para Foucault, los procesos de poder que involucran al cuerpo no acaban nunca de disciplinarlo por completo. En otras palabras, como lo afirma la autora, "las historias no capturan el cuerpo al cual se refieren" (Butler, [2005] 2009, 59). Por lo demás, así como en el plano ontológico los discursos no alcanzan a aprehender con plenitud al sujeto al cual interpelan, del mismo modo los cuerpos no siempre son clasificables dentro de las grillas de inteligibilidad que los dotan de su estatuto. No se trata, de hecho, de dos procesos independientes: las normas que reclaman un tipo de subjetividad determinada exigen e implican una cierta morfología corporal. Para Butler, el quid del asunto estriba en que, no obstante el hecho de que las normas que rigen la materialización generan identificaciones esencializantes, dichas identificaciones son siempre denunciables en su accidentalidad. Paradójicamente, es el propio cuerpo el que se encarga, al asumir morfologías no disciplinadas, de evidenciar dicha accidentalidad. Así, si bien la articulación de una ontología política que determina lo que resulta legible como cuerpo constituye una operación que busca instituir una cierta estabilidad so pena de castigo, la operación inversa, consistente en develar el carácter contingente de dicha articulación, también se despliega a través del cuerpo.

De esta manera, el concepto de abyección propuesto por Kristeva es traído a colación por Butler para dar cuenta del modo en que las subjetividades críticas reoperan en las normas 
que regulan la vida corporal. Como se sabe, para Kristeva lo abyecto hace referencia a aquello que es expulsado del yo para que dicho yo sea capaz de constituirse. No obstante, según la autora, lo abyecto no deja jamás de acosar la identidad que se forja a partir de esa exclusión; lo abyecto, en este sentido, es "aquello que perturba una identidad, un sistema, un orden[,] aquello que no respeta los límites, los lugares, las reglas” (Kristeva, [1980] 2006, 11). Butler, interpretando a Kristeva, señala que los cuerpos abyectos son portadores de una crítica al poder social. Para Butler, la

[...] amenaza y [el] rechazo que suscitan [los cuerpos abyectos] no [necesariamente los limita a] una oposición permanente a las normas sociales condenada al pathos del eterno fracaso, sino [que] más bien [esa amenaza y ese rechazo constituyen el terreno en el cual se hace posible] la lucha por rearticular los términos mismos de la legitimidad simbólica y la inteligibilidad (Butler, [1993] 2008, 20-21).

En este sentido, la relación entre las normas y los cuerpos no responde dentro del esquema posestructuralista de Butler a una dialéctica de la cooptación como la presente en Simmel o la Escuela de Birmingham. Los cuerpos abyectos no son cooptados de manera completa por la normas en tanto estas se afirman sobre la base de la repetición performativa. En torno a las normas y las prácticas corporales que pretenden desafiarlas hay, pues, una disputa permanente por la hegemonía y no una lucha encaminada a resolverse en una síntesis abarcadora. Butler, de hecho, opone a las lecturas totalizadoras de Hegel una lectura de dicho autor que privilegia la negatividad y la incompletad introducida por el deseo (Butler, [1987] 2012). En esta medida, los cuerpos abyectos se caracterizan por su acecho crítico de la norma; el potencial crítico y la indocilidad de dichos cuerpos radica, pues, no únicamente en su oposición a la normalidad, sino también en su capacidad de trastocar las propias grillas de inteligibilidad corpóreas (Butler, [1993] 2008, 21).

La subversión performativa, en esta medida, no constituye una estrategia meramente defensiva. El performativo no se agota en un disenso corporeizado con respecto a las normas, sino que también se trata de un dispositivo estilístico que habilita al sujeto para combatir esas normas ensanchándolas. Esa dimensión activa del performativo para 
Butler, de hecho, central en relación con el tema del estilo. En efecto, si las normas subsisten sobre la base de su reiteración y los cuerpos son los encargados de llevar a cabo dicha reiteración, en el desacatamiento de las mismas hay en juego un ensanchamiento estilizado de los parámetros ontológicos que rigen lo materializable. El estilo, según Butler, es por tanto un modo de trabajar el cuerpo a través del cual se posiciona al mismo en relación con las normas (Butler,[1990] 1998, 300). Para la autora, en esta medida, los estilos no necesariamente son subversivos: la obediencia a las normativas corporales se encarnan igualmente a la manera de un estilo. No obstante, los estilos pueden ser portadores de la crítica precisamente cuando echan mano de la performatividad como un modo de evidenciar la arbitrariedad de las normas. Para Butler la crítica constituye, en esta medida, un parámetro ético a partir del cual la repetición estilizada de los actos puede llegar a trastocar las normas que rigen la vida corporal (Butler, [1993] 2008, 272275).

En la vida social, sin embargo, (pero también en la historia, como habrá oportunidad de constatar en el capítulo siguiente) la faceta reactiva y la faceta creativa de la crítica se confunden: mostrar la contingencia de la norma con el propio cuerpo implica ya, según Butler, en algún sentido comprometer dicha norma -o "doblarla", como lo diría Deleuze ([1986] 1999, 160)-. En este sentido es que Butler se refiere a una "desorganización capacitadora" (Butler, [1993] 2008, 49), a saber: según la autora agitar los parámetros que hacen inteligibles los cuerpos implica ejercer un poder que confunde para reorganizar.

El cuestionamiento de las normas corporales, no obstante, no tiene lugar a partir de un mero antojo de distinción. No se trata (o en todo caso no se trata únicamente) de un divertimento dirigido a mostrar las arbitrariedades de las normas corporales: las subversiones en las que piensa Butler, según ella misma lo indica, están animadas, por el contrario, por deseos de reconocimiento sostenidos en el tiempo -y no por ninguna interioridad esencializada- . En este sentido es que discrepar con la normas que rigen la vida corporal implica un cierto nivel de crítica: se trata de una forma de indocilidad en la que ciertos cuerpos, paradójicamente no reconocidos como tales, reivindican para sí su 
estatuto de cuerpos (Butler, [2002] 2011). Los cuerpos abyectos, por tanto, no buscan sencillamente ir en contra de las modas u otras normas corporales por desavenencias con una forma: se trata, por el contrario, de cuerpos deseantes que reclaman ser registrados por unas normas que, no obstante, se niegan a reconocerles.

Butler, a partir de su lectura de Hegel, subraya precisamente esa relación estratégica que la repetición estilizada de los actos posee con el tema del reconocimiento. $\mathrm{Si}$, como lo señalé en el capítulo anterior, el reconocimiento designa para Butler el drama sostenido por los sujetos deseantes en su afán de afirmarse como autónomos a pesar de la alienación constitutiva que experimentan debido a la existencia de los otros (Butler, [1987] 2012, 93), la dimensión corporal involucrada en los procesos de reconocimiento es innegable. Como lo indica Femenías, el reconocimiento en los trabajos tempranos de Butler parecía designar, ante todo, un problema ontológico/retórico que dejaba de lado la dimensión propiamente material de dicho fenómeno (Femenías, 2007, 120). En razón de esa limitación, la filósofa norteamericana intenta en sus trabajos posteriores dar cuenta de cómo en el problema del reconocimiento están en juego criterios definitorios respecto de los cuáles se define qué cuerpos importan. En los procesos de reconocimiento, por lo tanto, hay una disputa material estilizada alrededor de los parámetros que, paradójicamente, rigen lo materializable. En este sentido, si como lo indica Femenías los procesos formativos de conciencia incorporan "una articulación entre lo material y lo formal" (Femenías, 2007, 120), las luchas estilizadas por el reconocimiento, involucran el cuerpo y su presentación como soportes materiales.

Por otro lado, siendo que para Butler los estilos se producen en el marco del drama del reconocimiento, la labor de acecho por parte de esos cuerpos en relación con las normas que intentan capturarlos no se realiza de una forma voluntarista. Partiendo de MerleauPonty, Butler sitúa, en cambio, los procesos performativos en el marco del ejercicio de una libertad situada. Para la autora, en efecto, el "estilo [style] nunca se auto-estiliza [selfstyled] totalmente, porque los estilos vivos tienen historia, y esta historia condiciona y limita las posibilidades" (Butler, [1990] 1998, 300). Al igual que Merleau-Ponty, Butler como también Foucault- considera que el estilo despliega una libertad limitada. De este 
modo, la filósofa no circunscribe el ejercicio de la crítica a una voluntad individualista: los estilos, según Butler, son en realidad ejercicios públicos - por efecto de su despliegue en el marco de la vida social-, temporales -dada su dimensión performativa- y colectivos -toda vez que un estilo individual está destinado a perder toda su fuerza política- (Butler, [1990] 2007, 273). Para Butler, así, el estilo no es un divertimento singular, sino una estrategia en la que algunos colectivos se juegan la posibilidad del reconocimiento.

Contrariamente a lo aseverado por los autores de la Escuela de Birmingham, para Butler la capacidad limitada de los estilos no surge, por otra parte, de las dinámicas consumistas, sino a partir de condicionamientos históricos más amplios. Las rupturas del estilo, en esta medida, requieren para Butler, tal y como ya lo había señalado Foucault, de una labor estratégica que se asiente en la historia. En otras palabras, los actos corporales estilizados obtienen su eficacia crítica del carácter situado de su aplicación. Para Butler, en esta medida, no basta con que los estilos corporales subversivos se deriven del trabajo que el sujeto realiza consigo mismo: para que la crítica sea eficaz en términos emancipatorios, ese trabajo debe incluir, además, una estrategia colectiva que permita su despliegue público. De este modo, a la dimensión ética y estética de la estilística de la existencia foucaultiana, Butler añade una dimensión eminentemente política: los estilos, efectivamente, si quieren trastocar verdaderamente las normas corporales, deben inscribirse en empresas colectivas que los soporten.

Mediante la irrupción de la dimensión performativa Butler establece, siguiendo tanto a Merleau-Ponty como a Foucault, una comprensión no esencialista del estilo. Para la autora, en efecto, el estilo se inscribe en el marco del asunto del reconocimiento de un sujeto cuyo drama consiste, precisamente, en no ser registrado como tal. En esta medida, las elaboraciones butlerianas permiten ubicar el estilo por fuera del ámbito del consumo e inscribirlo dentro de un desafío ético y político más amplio, a saber: el de cómo ensanchar los parámetros a partir de los cuales se determina cuáles son los cuerpos que importan. 


\subsection{Cuerpo, vestimenta, performatividad y crítica: hacia una teoría del estilo}

A partir de las posiciones precedentes se abre un espectro de posibilidades en lo tocante a las potencialidades subversivas del estilo y de una utilización políticamente contestataria de la vestimenta. En concreto, los autores abordados a lo largo del presente capítulo permiten ligar el tema del estilo con el cuerpo, la vestimenta, la crítica y la performatividad. Esos ligámenes resultan pertinentes en la medida en que muestran posibles relaciones éticas y políticas entre el cuerpo y el vestido allende las formas disciplinarias y los mecanismos de control biopolítico estudiados en la segunda parte de este trabajo. Mediante las tesis examinadas en el presente capítulo, así, el estilo aparece como un fenómeno distinguible de la moda. ${ }^{36}$ En razón de ello, en este apartado ensayaré una síntesis articuladora de algunos de los rasgos atribuidos por los autores estudiados en los apartados anteriores. En concreto, destacaré la utilidad de pensar los estilos vestimentarios en vinculación con el cuerpo (vía Merleau-Ponty), la emancipación política (vía Escuela de Birmingham), la crítica (vía Foucault) y, por último, la performatividad (vía Judith Butler).

Partiendo de Merleau-Ponty, el estilo se presenta, en primer lugar, como un fenómeno fundamentalmente corporal. El estilo, desde esta perspectiva, implica ciertamente un tipo de empleo del cuerpo en el que este establece diversas relaciones con el mundo. En esa medida, los ejercicios de estilo ponen en juego la posibilidad de un ejercicio situado de la libertad. Lo corporal, en relación con el estilo, aparece entonces simultáneamente como un campo lleno de posibilidades y como un ámbito en el que surgen múltiples condicionamientos. De hecho, complementando las tesis merleau-pontyanas con la perspectiva de Foucault y Butler, puede decirse que no hay un cuerpo por fuera de sus negociaciones con el mundo (es decir que los cuerpos siempre se remiten de uno u otro modo a normas y modos de ser que pretenden formarlo). Desde este punto de vista, el desfase entre la interpelación del poder y la respuesta del sujeto a dicha interpelación ofrece a los cuerpos una zona de indeterminación. Dicha zona de indeterminación, por

\footnotetext{
${ }^{36}$ También Echavarren distingue el estilo de la moda: "los estilos combaten el camaleonismo de la moda, su tedio consumista, creando una composición consistente, la contraseña de un modo de ser" $(2010,38)$.
} 
otra parte, al poner en juego criterios específicos sobre lo que es materializable y lo que no, implica, tal y como lo señala Butler, una disputa por y con el cuerpo. El hecho de que la formación ética del sujeto dependa de la interpelación de un poder que lo habilita no quiere decir, por tanto, que el cuerpo no pueda asumir una morfología alternativa al citar la norma vestimentaria de un modo inesperado. Esa citación alternativa es, de hecho, la que según Butler caracteriza los estilos críticos (Butler, [2000] 2011). Los estilos críticos consisten, en esta medida, en formas de lidiar con las normas corporales que a su vez intentan repercutir en ellas.

La filósofa francesa Catherine Malabou -estudiosa de Hegel, Heidegger y Derridaseñala en esta misma dirección que si "lo plástico" designa simultáneamente aquello susceptible de cambiar de forma y aquello capaz de dar forma, la subjetividad posee entonces una dimensión plástica. Según Malabou, en esta medida, en tanto receptiva y dadora de forma, la subjetividad "nunca es pasiva (...) sino una instancia plástica" (Malabou, 2010, 91). Mi opinión siguiendo a los autores estudiados en este capítulo es que mediante el estilo, esta dimensión plástica de la subjetividad otorga al cuerpo posibilidades rupturales. Así, considero que tal y como lo indica la teórica del vestido Susan Kaiser "preocuparse por las apariencias [minding appearances] es un proceso que puede ser usado para articular e incluso producir reflexividad y subjetividad" (Kaiser, 2001, 92; traducción propia). Si los cuerpos se componen, tal y como lo señalan Foucault y Butler a partir de Merleau-Ponty, a través de un trabajo ético continuado en correspondencia con unas ciertas normas vestimentarias y a través de unas ciertas prendas, los cuerpos críticos, asimismo, se despliegan echando mano de esos instrumentos. Justamente a esto se refiere Foucault cuando a partir de Kant plantea una estética de la existencia: se trata de establecer en torno a las normas un modo de sujeción alternativo en el que el cuerpo y el comportamiento se trabajen estética y éticamente adecuándose a unas prerrogativas que uno mismo ha elegido (Foucault, [1984] 2006, 87). ${ }^{37}$ Los estilos, leídos desde este prisma, resultan por lo tanto fenómenos corporales

\footnotetext{
${ }^{37}$ En un sentido similar Jean Luc Nancy señala que referirse al cuerpo estético constituye una "simple tautología" (Nancy, [2000] 2010, 29).
} 
que se erigen en relación con las normativas sociales en general y con las normativas vestimentarias en particular.

En segundo término considero que el estilo, tal y como lo señala la Escuela de Birmingham, designa asimismo un modo de relación política con la indumentaria. En este sentido, mi opinión es que es válido hablar de estilos propiamente vestimentarios (aunque nunca exclusivamente vestimentarios) toda vez que los ejercicios estilísticos involucran procedimientos en los que el cuerpo, como lo diría Merleau-Ponty, se "anexa" prendas para así ganar capacidades y posibilidades de acción. Tal y como lo señala Clarke, los estilos abarcan, en tal medida, procedimientos de selección y combinación de elementos indumentarios. Las prendas, desde esta perspectiva, pueden considerarse elementos técnicos para la subversión. Toda vez que, además, las prendas se in/corporan dentro de estilos que abarcan visiones de mundo y formas de vida, puede decirse que los estilos son capaces de dotar a las prendas de un contenido que por sí mismas no poseen. Por otra parte, siendo que, como lo señala Foucault, los procedimientos estilísticos se dan a través de un trabajo ético del sujeto consigo mismo, las prendas podrían entenderse asimismo como dispositivos técnicos de autogestión corporal. Así como en las disciplinas las prendas constituyen recursos técnicos de control corporal, en el estilo las prendas son utilizadas críticamente como técnicas de sí estilizadoras de la existencia y del aspecto. En este sentido, considero siguiendo a Foucault que las prendas pueden entenderse como instrumentos capaces de insuflar formas críticas al cuerpo; formas que, paradójicamente, no son independientes de la propia gestualidad crítica. Así, si bien en los ejemplos propios de la Antigüedad proporcionados por Foucault el estilo aparece conceptualizado mayoritariamente en términos de austeridad, existe - tal y como lo mostraré en el próximo capítulo- un espectro amplio de posibles usos críticos de la vestimenta allende la sencillez en el vestir. Desde esta perspectiva, las prendas, en su dimensión de objetos, revelan, en efecto, nuevas posibilidades: en tanto insumo técnico, la prenda contribuye ciertamente al disciplinamiento, pero del mismo modo, puede llegar a coadyuvar (y de hecho coadyuva, como se verá en el próximo capítulo) a que los sujetos lleven a cabo prácticas de libertad, es decir, prácticas en las que se ejercita una cierta reflexividad crítica -sobre la noción foucaultiana de prácticas de libertad véase Foucault ([1984] 
2010a, 1028-1029)-. En este sentido, tal y como lo señala adecuadamente Echavarren a partir de su examen de la noción de fetiche, la prenda puede llegar a articularse con el cuerpo no solo para hacerlo más dócil, sino también para dotarlo de nuevas funciones. Para Echavarren "el fetiche vale antes que nada como imagen o estímulo sensible", razón por la cual "es un agregado a su portador" $(2010,27)$. El autor propone comprender, de esta manera, "zapatos, pelo, cintas, joyas, modo de andar [y] gesticulación" (Echavarren, $2010,27)$ como fetiches que podrían potenciar los cuerpos. No obstante, antes que referirme al fetiche (con su inevitable resonancia psicoanalítica) prefiero pensar la prenda a partir de Foucault como un insumo técnico, debido a la connotación creativa y despatologizada de esta última expresión. Las técnicas de sí, según Foucault, son aquellas capaces de

[...] permitir a los individuos efectuar, por cuenta propia o con la ayuda de otros, cierto número de operaciones sobre su cuerpo y su alma, pensamientos, conducta o cualquier forma de ser, obteniendo así una transformación de sí mismos con el fin de alcanzar cierto estado de felicidad (Foucault, [1998] 2008, 48).

Las prendas, en tanto técnicas de sí, devienen por lo tanto instrumentos del estilo. Comprender la prenda como insumo técnico y el estilo como una técnica de sí permite pensar, por tanto, en la posibilidad de que "la preocupación por las apariencias [minding appearances] se conviert[a] en un vehículo visual para negociar e ingresar a espacios intersubjetivos y discursivos" (Kaiser, 2001, 81; traducción propia). No obstante, cabe recordar que, como lo señalan los autores de la Escuela de Birmingham, los estilos no se agotan en las prendas, razón por la cual hay que pensar en la relación entre aquel y estas como una relación instrumental. Los estilos, así, no tienen porqué comprometerse a un empleo perenne de una determinada prenda o conjunto de prendas, por la sencilla razón de que los mismos desbordan su dimensión propiamente indumentaria y hacen parte, como lo diría Foucault, de modos de vida. Considero, por lo tanto, que las prendas constituyen insumos técnicos a partir de los cuales es posible llevar a cabo ejercicios estilísticos, si bien dichos ejercicios no se agotan en su veta indumentaria. 
En tercer lugar, me parece igualmente pertinente la vinculación del estilo con la crítica. Si las tensiones entre la moda y el estilo aluden a los distintos procesos de subjetivación susceptibles de llevarse a cabo en relación con la indumentaria, la vinculación entre crítica y estilo permite el establecimiento de un criterio a partir del cual emprender la construcción de anatomías indóciles. Contrariamente a lo señalado por Clarke, sostengo en este sentido que en el ámbito del vestido la dilucidación del criterio definitorio de lo transformador debe remitirse al grado de eficacia crítica de un estilo dado. Si la denuncia de la "solución mágica" de la Escuela de Birmingham consistía en señalar que los colectivos juveniles intentan resolver en los espacios de ocio unas asimetrías que en verdad provienen del ámbito de la producción económica, un posible abordaje alternativo, por lo tanto, podría consistir en poner el acento, a partir de Foucault y Butler, en la relación crítica de los estilos con las normas sociales, especialmente con aquellas vinculadas al cuerpo y al asunto del reconocimiento. En otras palabras, si bien la desavenencia en relación con una moda dada no constituye por sí misma una forma de estilo, la inscripción de esa desavenencia en un marco crítico tal y como lo entiende Foucault, podría dotar ese mismo gesto de una dimensión estilística.

En esta medida, si bien entendidos en el marco de las sociedades de consumo los estilos son de hecho cooptables, comprendidos como formas de crítica corporal los estilos son capaces, tal y como lo señala Butler, de ensanchar críticamente los parámetros de legibilidad. En el estilo no se trata, por lo tanto, de una mera disidencia estética sublimatoria de unos poderes que en verdad están teniendo lugar en otro sitio, sino de una rebelión corporal que apunta al plano de la ontología y de los parámetros que determinan quién cuenta como sujeto. En este sentido, considero, interpretando a Foucault y a Butler, que las disidencias estilísticas alcanzan a desviar la norma cuando, en términos generales, se acompañan de la crítica. Así, como lo señala Foucault a partir de su interpretación de Kant, al asentarse en un cuestionamiento del modo en que se ejerce el gobierno sobre los cuerpos, la crítica es capaz de poner en cuestión los límites de la subjetividad tal y como esta es construye epocalmente. La crítica, en esta medida, augura una amplia aplicabilidad para el estilo: la crítica estilística, de hecho, constituye un ejercicio siempre situado y mutable, tal y como lo sugiere Merleau-Ponty. En otras palabras, la crítica 
estilística, al irrumpir siempre situacionalmente, puede atacar una diversa gama de dispositivos de poder. De hecho, allí donde el biopoder vestimentario se aplica, existen las condiciones de posibilidad para llevar a cabo críticas de estilo. En esta medida, como lo señala la teórica cultural Susan Keiser, "el estilo [es] una estrategia creativa y crítica para negociar nuevas verdades y subjetividades" (Keiser, 2001, 83; traducción propia).

En cuarto lugar, me parece adecuado ver en el estilo, partiendo de Butler, un tipo de crítica corporal que se despliega a través del tiempo. Toda vez que según la pensadora estadounidense los estilos corporales cuestionan las normas a través de una serie de actuaciones performativas disonantes, los estilos son conceptualizables como recursos útiles en la búsqueda histórica de reconocimiento. La articulación de estilos por parte de los cuerpos abyectos involucra, en esta medida, reclamos de visibilización en relación con las normas sociales. Así, el problema del reconocimiento, en relación con la vida corporal, ofrece la posibilidad de realizar un trabajo crítico con el propio cuerpo que se despegue de la norma y la cuestione. Los estilos aluden justamente a esa posibilidad de in/corporar la crítica a través de la citación: citar una norma vestimentaria implica reafirmarla, aunque en dicha reafirmación sea posible un desplazamiento que troque los propios efectos deseados por la norma y genere efectos inesperados -véase al respecto Butler, ([1993] 2008, 181) y ([1997a] 2004, 88)-.

Sin embargo, tal y como lo advierten los teóricos de la Escuela de Birmingham, no hay que olvidar que la capacidad ruptural de un estilo depende de un cierto empeño político de resignificación: no toda variación estilística rompe con una cierta moda dada. Ello introduce un desafío propiamente histórico para los estilos: ¿cómo introducir variaciones dentro del propio aspecto para que un estilo no pierda su eficacia? Butler señala en este sentido que es menester determinar "qué es lo que hace que algunos tipos de repetición paródica sean verdaderamente trastornadores, realmente desasosegantes, y qué repeticiones pueden domesticarse y volver a ponerse en circulación como instrumentos de hegemonía cultural". (Butler, 2007, 270-271). En este sentido, mi propuesta al referir el asunto del estilo al campo del reconocimiento pasa por eludir el problema del voluntarismo y por inscribir la crítica estilística en contextos siempre situados. En esta 
medida, si como lo señala la teórica cultural feminista Susan Keiser la ropa es condición necesaria para la subjetividad (Keiser, 2010, 82), mi opinión es que aquellas formas/sujeto que aspiren a ser reconocidas por el poder no pueden menospreciar la riqueza instrumental que las prendas reportan en tanto soportes materiales del reconocimiento. Así, si ciertas discriminaciones tienen lugar a partir de la presentación corporal, la subversión vestimentaria tendría entonces que pasar por desplegar su crítica a partir de estilos corporales situados. Así lo sugiere Butler cuando señala que la crítica de las normas debe incluir no solo un análisis de cómo la presentación corporal genera estereotipos en relación con las capacidades de cada quien, sino también el modo en que la presentación corporal puede ensanchar los parámetros de lo legible (Butler, 2000, 56).

En este sentido, me parece pertinente insistir en que el ejercicio crítico no surge de una voluntad individual, a la manera de una decisión soberana. Deleuze aclara, en ese sentido, que sujeto no tiene porqué designar restrictivamente a una persona, y que subjetivación tampoco alude a algo que en sentido estricto le ocurra a alguien (Deleuze, [1986] 1999, 160). En esta medida, los procesos de subjetivación estilística no constituyen esfuerzos singulares o individuales: por el contrario, los estilos tienen tanto mayor eficacia crítica cuanto más se despliegue a través de un colectivo. Butler, como ya he indicado, señala que los ejercicios de crítica corporal surgen a partir de un espesor histórico y político en el que se asientan. $\mathrm{Al}$ referirse a los estilos corporales, la autora sugiere, en efecto, que es necesario que esos estilos se sigan de (no en un sentido temporal de sucesión sino en el sentido ontológico de que respondan a) una crítica política colectiva. Los cuerpos estilizados requieren, pues, de insumos ontológicos alternativos con base en los cuales formarse, aunque, en rigor, esos insumos no preexisten a los cuerpos sino que despliegan "con" y "en" ellos. Si la materialización del cuerpo depende de la relación entre este y las verdades históricas en relación con las cuales se forma, el estilo consiste en poner al cuerpo en relación con otras verdades no instituidas ( $\mathrm{y}$, paradójicamente, no necesariamente dadas con anterioridad al propio ejercicio crítico). No obstante, la eficacia de ese desplazamiento está directamente relacionada con la fuerza con la cual se lleva a cabo: el estilo, en mi opinión, es capaz de romper o de cuestionar normas cuando es puesto en escena a través de acciones colectivas. Por lo tanto, la efectividad de un estilo 
está directamente relacionado con su capacidad de provocar algo más que disidencias singulares. En esta medida, por cierto, considero que la relación entre el estilo y la moda, si bien en principio es una relación de oposición, pensada en el marco de los reclamos de reconocimiento puede llegar a trascender su antagonismo: el hecho de que una práctica en principio minoritaria se instituya como moda, puede traer consigo, a la larga, el reconocimiento de cuerpos otrora considerados abyectos. En cuarto lugar, por lo tanto, en tanto forma de articulación de un reclamo por el reconocimiento, los estilos in/corporan una dimensión temporal que permite, mediante la performatividad, el cuestionamiento crítico y situado de las normas.

Recapitulando, considero partiendo de Merleau-Ponty, que el estilo en primer término se encuentra ligado a cuerpos en situación; en tensión con las determinaciones del mundo, el estilo hace irrumpir, por tanto, modos y significaciones, gestualidades y pliegues. En segundo término, considero que el estilo se encuentra vinculado, según lo he indicado a partir de la Escuela de Birmingham, a un uso contrahegemónico de la indumentaria. Las prendas, en tal sentido, se revelan como insumos socialmente disponibles para un uso político. Contrariamente a lo aseverado por los autores de dicha Escuela, sin embargo, dicho uso, a mi juicio, desborda el ámbito semiótico y abarca algo más que un problema de consumo. En tercera instancia, tal y como lo señala Foucault a partir de su concepción sobre la estilística de la existencia, considero que los estilos involucran un uso subjetivante de las prendas que se inscribe dentro del contexto del trabajo crítico del sujeto consigo mismo. Por último, como lo señala Butler, me parece que ese trabajo crítico se despliega a lo largo del tiempo, en razón de lo cual cabe pensar el estilo antes como una labor performativa que se desarrolla temporalmente que como una instancia fundacional de una subjetividad esencializada. El estilo, en esta medida, constituye a mi juicio un ejercicio político continuado y colectivo, normalmente referido al problema del reconocimiento.

A partir de una lectura complementaria de estas tesis, por lo tanto, considero el estilo un fenómeno distinguible de la moda fundamentalmente caracterizado por su vocación crítica, su dimensión corporal, su uso estratégico de la vestimenta y su carácter 
performativo. El estilo, desde esta perspectiva, permite entonces pensar en un uso de la prenda allende el disciplinamiento. No obstante, toda vez que dicho disciplinamiento, como he indicado en los capítulos 3 y 4 , se ancla fundamentalmente en el binarismo de género, considero pertinente, por último, analizar de qué modo la crítica estilística podría estar vinculada a la problematización ética y política del dualismo sexual.

\subsection{Los estilos de género}

Ciertamente, como lo he indicado ya, el género posee un papel organizador de las prácticas de poder que tienen lugar en torno a la moda. Por ende, indagar a propósito de la relación que el estilo establece con respecto al género implica considerar un uso crítico de la prenda en relación con una zona neurálgica del poder vestimentario. En otras palabras: si la moda es una práctica de biopoder que produce fundamentalmente cuerpos generizados, la pregunta es de qué manera las prendas que instituyen las "verdades" de género podrían llegar a contribuir a su crítica. Quisiera concluir este capítulo, por lo tanto, dando un cariz de género a las reflexiones precedentes sobre el estilo.

La relación entre las tecnologías productoras del género y la crítica no es ajena al feminismo. Diversas autoras, de hecho, han intentado pensar desde un punto de vista feminista las técnicas de sí y su potencial transformador de las relaciones de género. En su ensayo La tecnología de género, por ejemplo, Teresa de Lauretis señala que

[...] el género no es una propiedad de los cuerpos o algo originalmente existente en los cuerpos humanos, sino el conjunto de efectos producidos en los cuerpos, los comportamientos y las relaciones sociales, o en palabras de Foucault, por el despliegue de una tecnología política compleja (de Lauretis, [1989] 1996, 8).

Para la autora, en virtud de que existen tecnologías de producción del género es posible volcar esas mismas tecnologías en contra del esencialismo. Según de Lauretis, en esta medida, "la construcción del género es también afectada por su deconstrucción; es decir, 
por cualquier discurso, feminista u otro, que pudiera dejarla de lado como una tergiversación ideológica" (de Lauretis, [1989] 1996, 9).

Las tecnologías de género se inscriben, de este modo, dentro de la producción política del género, la cual "es tanto el producto como el proceso de su representación" (de Lauretis, [1989] 1996, 11). En otras palabras, para la teórica italiana, las técnicas que dotan de coherencia al género son empleables también para develar su contingencia. De Lauretis proporciona algunos buenos ejemplos de usos feministas de las tecnologías de género (el cine y los discursos, por ejemplo) pero no incluye dentro de ese repertorio de tecnologías al vestido.

En el pensamiento de Butler este mismo esquema reaparece relacionado con las prendas y el estilo. Butler, como ya he señalado, considera que los estilos están vinculados de forma compleja con el binarismo sexual (Butler, [1991] 2000, 104). Para la autora, la crítica estilística involucra, ciertamente, una crítica a la identidad tal y como esta se forja en el marco del binarismo de género. En esta medida, según Butler, si bien los estilos pueden reforzar el binarismo, igualmente pueden avocarse a su deconstrucción.

La conceptualización butleriana de la performatividad está asimismo relacionada con la pretensión de denunciar el carácter coercitivo del binarismo sexual. En la medida en que el performativo, como lo he indicado antes, se encuentra vinculado a una repetición estilizada de actos que introduce la posibilidad de un fallo en la normativa binaria, los estilos pueden llegar a servirse de esta dimensión performativa para mostrar la arbitrariedad de las normas que rigen la vida del cuerpo sexuado.

Así, en su discusión a propósito de la violencia intrínseca a la diagnosis de género, Butler lleva a cabo una crítica a propósito de la idea de que las prendas pertenecen "originalmente" a uno solo de los géneros. Para la autora, en el uso no dicotómico de las prendas, de hecho, 
[...] hay un cierto imaginario en juego, una capacidad de transfigurar una prenda en otra a través de un proceso de improvisación y sustitución; [se trata] de una práctica de destreza que difícilmente se podría nombrar, de una forma simple, como el mero acto de conformarse con una norma. Algo está haciendo hecho, algo se está haciendo de otra cosa, se está intentando algo. (Butler, [2004] 2006, 142).

Para Butler es concebible, en este sentido, un empleo crítico de las prendas en aras de crear realidades corporales allende el binarismo sexual. La vestimenta, en tanto recurso tecnológico, permite ciertamente vislumbrar la posibilidad de convertir el aspecto del cuerpo sexuado en algo distinto a aquello que se espera que sea. Las prendas, en tanto dispositivos estilísticos hacen posible, por lo tanto, un trabajo ético sobre el propio cuerpo capaz de variarlo en su dimensión generizada. El cuerpo se convierte, de esta manera, en un soporte material de la crítica al binarismo sexual.

Esta utilización de la prenda como una tecnología subversiva de género permite, pues, pensar el estilo como un enclave de la crítica al binarismo. En tanto recursos críticos, las prendas posibilitan, en esta medida, desplegar bajo la forma del estilo diversas verdades corporales alternativas al binarismo esencialista.

Por otra parte, en el caso de los estilos de género -como ya lo he señalado antes en relación con el estilo en general- los esfuerzos resignificadores pueden adoptar múltiples gestualidades y formas. En otras palabras, no hay un solo modo de adoptar estilos críticos de género, sino que cada estilo debe encontrar la manera de subvertir las normas que critica. De ahí que los estilos de género no privilegien la identificación por sobre la desidentificación -ni viceversa-. Sus recursos, por el contrario, varían según la situación opresiva de turno y abarcan, por ejemplo, tanto la parodia como la apropiación estetizada del espacio público. Del mismo modo, pueden apelar a la ambigüedad, la exageración, la introducción de discontinuidades entre la apariencia y el comportamiento o entre la apariencia y el comportamiento sexual y erótico, la invención de nuevos placeres visuales y corporales, la deconstrucción de criterios normalizadores y la potenciación prostética del cuerpo entre muchas otras tácticas más (en el capítulo siguiente mostraré algunas de estas estrategias tal y como se han desplegado en coyunturas históricas particulares). 
Lo definitorio de las técnicas estilísticas de género es, por tanto, su talante crítico con respecto al binarismo sexual. No obstante, si como lo señala Butler el género ha funcionado históricamente como criterio rector de lo humano (Butler, [1993] 2008, 32 33), entonces la crítica de género deviene de un modo general una crítica al cierre del significante "humano". Toda vez que, como he argumentado antes, el cuerpo humano se ha pensado históricamente como un cuerpo sexuado por antonomasia, los estilos de género, en efecto, contienen el germen para una crítica radical de la subjetividad y la normalización del cuerpo tal y como esos fenómenos se despliegan alrededor de la moda. En la medida en que la crítica de las técnicas estilísticas de género apuntan a ensanchar el espacio de la definición de lo humano, considero, por lo tanto, que los estilos de género poseen un potencial particular para irradiar su crítica a otras esferas y así atacar un punto sensible del poder vestimentario.

En otras palabras, la particular relevancia que en mi opinión poseen los estilos de género viene dada por su capacidad de forzar el reconocimiento de los cuerpos no calificados como humanos, o peor aún, no calificados como cuerpos, según el sentido normativo del término. De este modo, las técnicas estilísticas de género se refieren inicialmente al género por cuanto este constituye el enclave metafísico por antonomasia de la antropología filosófica occidental, pero no se refieren restrictivamente a él: su horizonte, de hecho, es el de la inclusividad radical. Más aún, sus posibilidades de éxito pasan por su capacidad de facilitar interferencias con las más variadas formas de resistencia. De ahí que en las próximas páginas prestaré atención a los ejercicios de estilo vinculados al género, aún cuando ese no sea el único itinerario teórico posible en lo tocante al estudio del estilo.

En síntesis, a partir de las argumentaciones anteriores he pretendido mostrar que la moda no es la única institución orientada a regir las relaciones entre la subjetividad y las prendas. También el estilo, en tanto forma de trabajar el propio cuerpo, presenta un modo de poner en relación el cuerpo y las prendas que lo (con)forman. En el límite, podría decirse que ningún cuerpo puede ser trabajado (es decir, mantenido con vida, adornado, 
curado, transformado, etc.) sin mantener una cierta relación con la verdad -entendida esta en un sentido foucaultiano-. Lo propio del estilo, en esta medida, es ofrecer al cuerpo una verdad crítica para que este pueda establecer una relación alternativa con las normas vestimentarias que lo habilitan. Por otra parte, dado que el género se proyecta como un enclave central del biopoder vestimentario, los estilos de género constituyen una interesante opción crítica en la medida en que su impulso epistemo/ontológico es capaz de derribar los presupuestos metafísicos de la antropología filosófica dominante. En otras palabras, los estilos de género, como mostraré en el próximo capítulo, contienen el germen para desplegar una crítica radical de la subjetividad normalizada, sobre todo si se toma en cuenta que dicha subjetividad, tal y como se ha desplegado históricamente, tiene en el binarismo esencialista su principal punto de referencia. En tanto gestualidad subversiva, por lo tanto, el estilo es un ejercicio deconstruccionista. Pero, en tanto práctica política de reconocimiento, el estilo puede dirigir sus ataques a diversas formas de esencialismo allende el ámbito de género. En este sentido, el estilo, atento a los vacíos de las normas, trama subversiones en los pliegues del poder y asume la forma de una ética. En el siguiente capítulo discutiré algunas de las manifestaciones históricas de esa ética. Para ello pasaré revista a ciertas expresiones colectivas de estilos contrahegemónicos y analizaré sus estrategias, aciertos y limitaciones. 


\section{Capítulo 6. Dandismo y feminismo: dos ejercicios críticos de estilo}

Si tal y como lo indiqué antes, los estilos asumen múltiples formas y variantes según el tipo de crítica que busquen desplegar, analizar un estilo particular implica pensar un conjunto abierto y mutable de gestos corporales, uno de cuyos instrumentos fundamentales es la vestimenta. Un estilo, vale la pena insistir en ello, no es un conjunto predefinido de reglas indumentarias o morales a seguir, sino más bien un tipo de histriónica y un ethos vestimentario críticos que se despliegan contextualmente. Por ese motivo, analizar un estilo determinado involucra no solo hacer un recuento de las prácticas vestimentarias de un determinado grupo social, sino también descifrar el contenido crítico de dichas prácticas. En otras palabras, analizar un estilo significa reparar en el despliegue de una ética corporal crítica y no simplemente decodificar una semiótica.

En tal sentido, mi objetivo en este capítulo no consiste en modo alguno en trazar la historia de los estilos críticos (tarea que merecería una investigación aparte), sino en cartografiar de manera tentativa dos matrices estilísticas particularmente relevantes tanto a la luz de las críticas a la moda que he realizado en los primeros capítulos de este trabajo, como de la teoría del estilo que he propuesto en el capítulo anterior; me refiero al feminismo y al dandismo. ${ }^{38}$ Particularmente me interesa analizar dichos ejercicios en su dimensión corporal, "aletúrgica” (véase el capítulo anterior), más que en su dimensión propiamente textual (análisis este último que también sería posible, dado que los estilos en cuestión cuentan con una suerte de canon: en el caso del dandismo me refiero a todo un conjunto de textos literarios producido por dandis, mientras que en el caso del estilo feminista a la teoría feminista propiamente dicha). En otras palabras, en las páginas que

\footnotetext{
${ }^{38}$ Algunos autores conservan la letra " $y$ " del inglés a la hora de utilizar las nociones "dandy" y "dandysmo" en castellano. Por mi parte, utilizo las formas castellanizadas "dandi" y "dandismo" tal y como aparecen en la mayoría de las ocasiones tanto en los diccionarios como en las traducciones de libros dedicados a la temática.
} 
siguen me interesa analizar estos estilos tal y como se han presentado bajo la forma de ethos o modos de ser corporales.

En cuestiones de estilo, de hecho, múltiples itinerarios teóricos son posibles. Esto, no obstante, no se ha traducido en un espectro de investigaciones demasiado amplio. De hecho, mientras que, para muchos estudiosos, las etnografías provenientes de la sociología y la antropología tienden a limitarse a ejercicios estructuralistas que buscan subsumir los desacatos estilísticos dentro del problema de la clase y analizar la dimensión semiótica de las diferentes subculturas estudiadas -dejando en un segundo plano el cuerpo- ${ }^{39}$ la filosofía, por su parte, no se interesa demasiado en estas cuestiones -una excepción es el trabajo de Roberto Echavarren ya mencionado, Arte andrógino: estilo vs moda, en el que el crítico uruguayo realiza una genealogía del mutante o andrógino en tanto manifestación moderna de estilo (Echavarren, 2010, 79-123); más adelante retomaré algunas de las tesis del autor- .

En todo caso, múltiples disidencias sociales son susceptibles de ser analizadas en términos de estilo. En el recorrido que deseo realizar en este capítulo me interesa centrarme en dos estilos que de uno u otro modo han cuestionado mediante el vestido la normalización de género. $\mathrm{Si}$, como he señalado antes, es cierto que el género -en tanto mecanismo de subjetivación- y la moda -en tanto conjunto de técnicas de poder- poseen una relación de mutua dependencia, los ejercicios críticos que han tenido en el binarismo sexual su blanco probablemente sean los que mejor expresen las posibilidades transformadoras del estilo. Por ello me centraré en dos formas de crítica -dandismo y feminismo- que, como se verá, poseen, a mi juicio, varios puntos de partida similares, pero cuyos principales denominadores comunes son la utilización políticamente estratégica del vestido y la preocupación por deconstruir algunos de los mandatos de género normalizadores del cuerpo. Ambos estilos, sin embargo, ponen el acento en diferentes aspectos de la crítica, por lo que también cabe hablar de los mismos como variantes estratégicas de estilo, es decir, como posibles gestualidades críticas susceptibles

\footnotetext{
${ }^{39}$ Véase Hall y Jefferson ([1975] 2000), Feixa (1999) y Reguillo (2000), así como la crítica a esos enfoques desarrollada en el capítulo anterior.
} 
de ser reproducidas, traducidas, interpretadas, adaptadas, reformuladas, trastocadas o enmendadas.

En suma, a través del análisis filosófico de estas dos formas de crítica corporal y de las gestualidades que les son propias mi intención es mostrar hasta qué punto las artimañas de la moda dependen de un acatamiento social que, en tanto posee un carácter performativo, es develable en su contingencia y, por lo tanto, fisurable.

\subsection{El estilo dandi}

Un dandi, según el historiador y ensayista británico Thomas Carlyle,

[...] es un hombre que lleva trajes: un hombre cuyo estado, oficio y existencia consisten en llevar trajes. Todas las facultades de su alma, de su espíritu, de su bolsillo y de su persona están heroicamente consagradas a este único fin: llevar los trajes de manera que sienten bien; de suerte que, así como otros se visten para vivir, él vive para vestirse. [Así, el dandi] es un inspirado del traje, un poeta del traje ([1835]) 1945, 291).

El propio Carlyle, sin embargo, señala que el dandismo es también "una modificación apropiada a [su] época [del] Culto de sí mismo" ([1835]) 1945, 294). En la primera sección de este capítulo deseo explorar esta doble veta del dandismo, a saber, su dimensión propiamente vestimentaria así como su vocación ética. Toda vez que en el dandismo estas dos dimensiones tienden a fundirse y a estar referidas una a la otra, pretendo mostrar el modo en que esa articulación se plasma bajo la forma de un estilo. Para estos efectos, analizaré, en primer lugar, la actitud crítica del dandi. Dado que la ética dandi, en efecto, se encuentra marcada por una cierta predisposición crítica, en el primer apartado discuto la manera en que esa predisposición se plasma en un tipo de actitud. En segundo lugar, intento analizar el sustrato epistemológico de dicha actitud o lo que Camus ha denominado la "rebelión metafísica" del dandi. Para ello, analizo el contenido metafísico, ético y político de la crítica dandi a la normalidad burguesa. En tercer lugar, discuto el uso dantista de la prenda, es decir, la relación espiritual que el 
dandi establece con la indumentaria y el modo en que esta opera a la manera de un recurso de subjetivación al interior de la ética dantista. Por último, doy cuenta de algunas de las limitaciones políticas del dandismo, específicamente las referidas a su excesivo culto a la singularidad y a su acriticidad con respecto al tema de las mujeres (miopía que llega hasta el punto de reducir el dandismo a un estilo exclusivo de varones). Mediante el desarrollo de estos puntos, mi intención, por lo tanto, es examinar el dandismo como la expresión histórica de un estilo vestimentario, es decir, como una forma estilística de emplear la prenda para crear un ethos crítico.

\subsubsection{El cuerpo dandi: vestimenta y actitud}

El dandismo, como ya he indicado con Carlyle, no se agota en una disidencia vestimentaria. El estilo dandi, de hecho, constituye una ética en el sentido foucaultiano del término; es decir, una forma de atenerse a un conjunto de lineamientos (estéticos, políticos, sexuales, filosóficos, etc.) que operan a la manera de criterios subjetivantes. Los dandis, en tal medida, si bien otorgan una importancia estratégica a la indumentaria, lo hacen en función de las virtudes que la misma provee en tanto elemento crítico. Así, si bien el dandismo puede ser leído en términos de una reacción de clase de una aristocracia venida a menos -como lo sostiene, entre otros autores, Walter Benjamin ([1974] 2012)-, también constituye una rebelión ética que incluye una interrogación metafísica sobre el estatuto del cuerpo y una crítica social a la normalidad burguesa. Es esta última faceta estilística del dandi la que me interesa poner de relieve acá en conexión con el uso dantista de la indumentaria.

En el contexto de una indagación a propósito de los estilos vestimentarios, no hay duda de que el dandismo constituye un momento fundamental. Mientras que algunos autores no llevan la historia de las rebeliones vestimentarias más allá de la segunda mitad del siglo XX -por ejemplo Rivière (1977, 131-136)-, otros, de hecho, consideran que las disidencias a nivel indumentario, al menos en su versión moderna, arrancan con el dandismo a partir del siglo XIX -véase, v. gr. Wilson $(2003,180)$-. Por mi parte, 
considero que esa historia podría remontarse bastante más atrás pues, como indiqué en el capítulo anterior, Foucault encuentra modos de sujeción alternativos a las normas vestimentarias (es decir, maneras alternativas de vincularse con una determinada regla indumentaria y de reconocerse interpelado para ponerla en práctica) ya en la Antigüedad. ${ }^{40}$ No obstante, más allá de si deba situarse o no en el origen de una genealogía de los ejercicios de estilo, lo cierto es que el dandismo es uno de los episodios clave en la historia de los estilos vestimentarios toda vez que la relación entre crítica e indumentaria es particularmente explícita dentro de la ética dandi.

Ya el propio desafío de situar geográfica e historiográficamente el dandismo dice algo acerca de la preeminencia que el dandi otorga a lo estilístico por sobre la moda. ${ }^{41} \mathrm{Si}$ bien el dandismo suele ubicarse en el marco del despliegue del capitalismo europeo y caracterizarse como una reacción aristocrática a las costumbres burguesas de los siglos XVIII y XIX -véase al respecto el análisis de Benjamin ([1974] 2012, 175)-, hay que decir que la circunscripción histórico-política del dandismo es, en efecto, bastante más compleja de elaborar. En su reconstrucción histórica de la rebelión, Camus, por ejemplo, remonta la estirpe del dandi hasta la figura bíblica de Caín ([1951] 2008, 22-84), mientras que el investigador y escritor chileno Juan Pablo Sutherland considera que el dandismo excede los límites europeos y habla de un "desembarco [dandi] en América Latina" (2011, 20). El teórico literario Dorde Cuvardic, por su parte, señala cómo algunos personajes latinoamericanos como Domingo Sarmiento adscriben, dentro de algunos de sus escritos, al dandismo (Cuvardic, 2009, 24), al tiempo que el propio Baudelaire indica que "el dandismo es una institución vaga (...); muy general, puesto que Chateaubriand la ha encontrado en las selvas y junto a los lagos del Nuevo Mundo" ([1862] 1995, 113). Esta dispersión geográfica y cronológica muestra cómo el núcleo del dandismo, lejos de consistir en una pertenencia a una época o región específicas, o incluso en unas prácticas vestimentarias determinadas, se define, sobre todo, por un tipo de actitud.

\footnotetext{
${ }^{40}$ Véase Foucault ([1984] 2003, 151 y [1984] 2004, 83). Por otra parte, véase también mi artículo Las artimañas de la moda: la ética colonial/imperial y sus vínculos con el vestido moderno (2009), donde tematizo algunas de las disputas ocurridas en torno al cuerpo vestido en el contexto de la invasión de América.

${ }^{41}$ A propósito de dicha preeminencia véase Echavarren (2010, 32-34), así como Barthes ([1962], 2003, 408).
} 
La actitud dandi, de hecho, ha sido puesta de relieve en varias ocasiones. Camus, por ejemplo, señala cómo la tarea del dandi "no consistirá solamente en crear un mundo, ni en exaltar la belleza por sí sola, sino también en definir una actitud" (Camus, [1951] 2008, 73). También Foucault, en su caracterización del ethos moderno antes aludida, indica que "la actitud voluntaria de modernidad [consiste en] tomarse a sí mismo como objeto de una elaboración compleja y dura" (Foucault, [1984] 2012c, 983) y añade que dicha actitud es propia del dandismo.

Sin embargo, la obra del dandi y escritor decimonónico Jules Barbey D`Aurevilly, Del dandismo y de George Brummel ([1845] 2008), quizá sea la que describe con mayor precisión la actitud crítica del dandi. En lo que se proponía como una semblanza de George Brummel, el dandi por antonomasia, ${ }^{42}$ el escritor francés $-y$ dandi también élBarbey D`Aurevilly señala cómo el dandismo

[...] es casi tan difícil de describir como de definir. Las personas que sólo ven las cosas por su lado más pequeño [agrega], imaginaron que el Dandismo era, por sobre todo, el arte del vestir, una dictadura feliz y audaz en cuestiones de acicalamiento y elegancia exterior. Sin lugar a dudas, también es eso; pero es mucho más. El Dandismo es toda una manera de ser, y no lo es solo por el lado de lo materialmente visible ([1845] 2008, 22).

La actitud dandi, por tanto, consiste en un modo de vestir y utilizar el cuerpo, pero no se agota en ello. De hecho, esa dimensión "materialmente visible" de la crítica dandi, tal y como la denomina D`Aurevilly, depende en verdad de una disposición crítica hacia las convenciones. Ello, por cierto, diferencia al dandi del excéntrico, pues mientras que aquel hace depender su aspecto de una disposición crítica, este último, en cambio, moldea su apariencia con base en el solo narcisismo (lo cual no quiere decir que el dandi no pueda ser excéntrico: de hecho muchas veces lo es; no obstante, dado que lo propio del estilo es efectuar una crítica situada, el dandi puede optar asimismo por formas de crítica corporal

\footnotetext{
${ }^{42}$ Brummel fue un personaje inglés de finales del siglo XVIII y principios del XIX. Ha sido considerado, en efecto, como el arquetipo del dandi. Se trata de una especie de eminencia de su época cuyos méritos dependieron exclusivamente de su actitud de desacato a las normas y de sus costumbres vestimentarias. Por fuera de su forma de vestir y de la fama que le granjeó inclusive entre la realeza, no hay, de hecho, mucho más que agregar a su biografía.
} 
que no pasen, necesariamente, por el excentricismo y que sean más eficaces para efectos de realizar una determinada crítica. Volveré sobre esta cuestión del sentido de la oportunidad del dandi más adelante). El dandismo opone, pues, tanto a las costumbres de la burguesía en ascendencia como a las de la vieja aristocracia, una subjetividad del tedio y la provocación. Así lo apunta Barbey D`Aurevilly: "una de la [las] principales características [del dandismo] es la de producir siempre el imprevisto, aquello que el espíritu acostumbrado al yugo de las reglas no puede preveer" ([1945] 2008, 24). Sartre, comentando el dandismo de Baudelaire, señala igualmente que en estos personajes coexiste la pretensión de "agradar y desagradar a la vez; el menor gesto es para el público" (Sartre, [1947], 1968, 127). También Camus plantea que "para el [dandi] estar solo equivale a no ser nada" (Camus [1951] 2008, 72). Este ethos de la provocación, esta actitud y esta propensión a desplegar públicamente con el cuerpo la crítica es, de hecho, lo constitutivo del dandismo.

Un ejemplo puede resultar particularmente ilustrativo al respecto. Se dice de Brummel que su elegancia despertaba la admiración y simpatía de la realeza de su época. Como parte de la altivez dandi, sin embargo, esto no generaba en Brummel más que indiferencia. En cierta ocasión, como resultado de esa actitud de hastío, Brummel llega incluso a burlarse públicamente de la gordura del Príncipe de Gales. Virginia Woolf, en su Beau Brummel ([1930] 2007), texto de homenaje al personaje en cuestión, escribe a propósito de dicho episodio:

[...] había humillado al propio Regente con su sutil “¿Quién es su amigo el gordo?", y su método era similar con la gente menos importante que lo trataba con desdén o que le aburría (...) Tal era su estilo, chispeante, burlón, rayano en la insolencia, lindando con el sinsentido, pero siempre rico en algún equilibrio (Woolf, [1930] 2007, §3). ${ }^{43}$

Esa actitud desafiante que hacía a Brummel burlarse de la falta de autocontrol de la realeza constituye, tal como lo apunta Virginia Woolf, algo más que una insolencia poco premeditada. El dandismo, en tanto ethos, exige de hecho que este tipo de predisposición confrontativa surja de cierta inclinación rebelde. El dandi es un provocador, y los

${ }^{43}$ La anécdota también se encuentra referida en D`Aurevilly ([1945] 2008, 54). 
personajes históricos que encarnan el dandismo varían en sus formas de acicalamiento e inclusive en sus portes, pero no en lo tocante a ese talante insolente.

Dicho talante, de hecho, hace parte de una antigua oposición de la historia ética vinculada al tema del estilo. Foucault, al contrastar el pensamiento político platónico y el bios philoshopikós del cínico señala, en efecto, que

[...] a lo largo de toda la historia del pensamiento occidental vamos a reencontrar (...) dos polaridades: el discurso filosófico [dirigido] al alma del príncipe (...) o el discurso verdadero de la filosofía [pronunciado] en la plaza pública, como desafío, como enfrentamiento, como irrisión, como crítica con respecto a la acción del príncipe y a la acción política" (Foucault, [2008] 2010, 300-301).

Según Foucault, de hecho, esa polaridad se encuentra condensada en otra anécdota (cuya similitud con de Brummel es, por cierto, manifiesta). Se trata del episodio en el cual Diógenes el Cínico se encuentra lavando una lechuga y Platón le espeta que si fuese más cortés con Dionisio -el entonces tirano de Siracusa- entonces no estaría obligado a lavarse su lechuga, a lo que Diógenes replica que si Platón estuviera acostumbrado a lavar su lechuga no habría sido esclavo de Dionisio -véase al respecto Foucault ([2008] 2010, 300-301)-. Brummel, como Diógenes, se inscribe por lo tanto dentro de esa estirpe de desafío y crítica al poder político. El dandismo, más en general, se ubica igualmente en el marco de esa polaridad descrita por Foucault del lado del crítico cínico. El dandi, de hecho, es lo que siguiendo a Foucault podría denominarse un crítico de plaza pública: un confrontador.

¿Pero de dónde extrae el dandi el sustrato epistemológico/ontológico de esa actitud crítica? Esta dimensión "aletúrgica" del dandismo (por hacer uso de esa noción ya descrita en el capítulo anterior) se basa de hecho en una ética entendida en un sentido foucaultiano -es decir, como un campo práctico y reflexivo en el interior del cual el individuo se constituye a sí mismo como sujeto moral (Foucault, [1984] 2003, 26-33)-. En el próximo apartado de este capítulo ahondaré en el contenido filosófico de la ética dandista. Por lo pronto, me interesa subrayar cómo todo el despliegue gestual del dandi surge de un ethos disidente y cuestionador de la moral hegemónica, especialmente en lo 
referido a su concepto de normalidad corporal y a su sentido de lo políticamente correcto. El repertorio "aletúrgico" del dandi incluye, entonces, una serie de ademanes que quieren hacer irrumpir socialmente "verdades" críticas. Me refiero a la tantas veces comentada afectación del dandi, a su vanidad, a su modo indiferente y a su obsesión con la elegancia y la indumentaria. En todo esos casos, de lo que se trata, en efecto, es de suscitar una reacción y de hacer irrumpir en la realidad una visión de mundo que difiere de la hipocresía burguesa y de la altivez aristócrata heredada por sangre (para el dandi, en efecto, la única altivez que vale es la que surge de la propia elegancia y del propio cuidado, esto es: la forjada a partir del trabajo consigo mismo). El dandismo, así, es una ética que esculpe el cuerpo como un modo de rechazar los mandatos corporales epocales dirigidos a la normalización del cuerpo masculino (no obstante la miopía dandi con respecto al modo en que esa normalización opera también sobre los cuerpos de las mujeres; volveré sobre el tema más adelante).

El despliegue público del cuerpo estilizado del dandi, no obstante, no debe confundirse con una simple traducción corporal de una ideología. El cuerpo dandi no transcribe una política, sino que por el contrario la inscribe: la construcción del propio cuerpo es concebida en el dandismo como una forma de hacer política, de hacer irrumpir en el ojo público unas posturas críticas que se tienen por verdades. El exhibicionismo dandi, así, constituye una forma de "militancia corporal", en el sentido foucaultiano de dicha expresión -véase Foucault ([2009] 2010a, 196-200)-. Dentro de la sensibilidad política del dandi jamás se escinde, en efecto, la crítica de la actitud corporal: la propia ascesis corporal, como veremos, es de hecho concebida como un ejercicio crítico. En este sentido, la rebelión dandi posee el objetivo de invertir la desvalorización del cuerpo -en particular del cuerpo masculino- y elogiar el "parecer" por sobre el "ser"; en otras palabras, a través de su crítica el dandismo aspira, en última instancia, a privilegiar lo sensible por sobre las esencias. Esta revuelta metafísica, de la cual me ocuparé a continuación es, de hecho, esencial para comprender el dandismo en cuanto estilo. 


\subsubsection{La rebelión estilística del dandi}

Tal y como señalé en el capítulo anterior, los cuerpos indóciles utilizan elementos estilísticos para desplegar morfologías críticas. En el caso del dandismo esta interacción entre el cuerpo y los núcleos críticos que lo in/forman responde a lo que Camus denomina la rebelión metafísica del dandi. "La rebelión metafísica es el movimiento por el cual un hombre [sic] se alza contra su situación y la creación entera. Es metafísica porque discute los fines del hombre [sic] y la creación" (Camus, [1951] 2008, 35). Para Camus, en esta medida, la rebelión dandi no se agota en una disidencia en el aspecto, sino que incluye una crítica a la sociedad. Dicha crítica, en el caso del ethos romántico del cual el dandi participa, tiene que ver ante todo con un desafío ante la ley moral y las costumbres aristocráticas, así como con un disenso en relación con los ideales productivistas y los modos masculinos de "ser". De igual manera, el dandismo despliega una crítica corporal en relación con la naturaleza y sostiene la preeminencia del arte y el acicalamiento por sobre el aspecto natural (me detendré en relación con este tema en el próximo apartado). El dandi, en tanto rebelde, dota su vida, en efecto, de unos modos y un talante que quieren desafiar tanto algunas convenciones metafísicas y morales de su época como algunas más referidas a las apariencias.

En opinión de Camus la rebelión metafísica del dandismo hace parte de una cierta rebeldía transhistórica. Según su criterio, el dandi, en tanto rebelde, responde en efecto a un aspecto de la naturaleza humana: "el análisis de la rebelión conduce (...) a la sospecha de que hay una naturaleza humana (...). ¿Porqué rebelarse si no hay en uno nada permanente que conservar?" (Camus, [1951] 2008, 26). Según el autor la rebelión dandi, por tanto, se ampara en una rebelión natural intrínseca al ser humano que no obstante que conoce de variantes, permanece a la manera de un núcleo moral. Sin embargo, el propio Camus concede una especificidad histórica a la crítica dandi. Para Camus, en efecto, el dandi se opone mediante la parodia a los valores morales y a la idea de una existencia acomodada y conformista, tal y como esta se instaló en la cultura aristocrática del siglo XIX (Camus, [1951] 2008, 72). Sutherland indica, asimismo, que el dandismo emerge como parte de un disconformidad hacia los ideales de vida aristocráticos así como de un 
deseo de hacer de la propia vida y el propio cuerpo obras de arte allende los ideales productivistas que comenzaban a ganar terreno para entonces (Sutherland, 2011, 16-18).

Las observaciones del especialista en estética Daniel Salvatore y de la teórica del arte española Gloria G. Durán señalan, en esta misma dirección, que el dandismo posee un núcleo duro de críticas referido a la moral mayoritaria y a las convenciones de la sociedad burguesa del siglo XIX. Según Salvatore, la ética dandi, de hecho, tiene su fundamento en el nihilismo, entendido por este autor con Deleuze como una negatividad activa y no como una simple negación pasiva (Salvatore, [2008] 2009, 98-99). En su Filosofia del dandismo ([2008] 2009), Salvatore sostiene, en efecto, que el dandismo emplea la misma sensibilidad filosófica desarrollada en la obra de Nietzsche y Kierkegaard, especialmente en lo referido a la pretensión de ambos autores de poner dentro de un continuum las dimensiones estética, ética y metafísica, con lo cual la crítica se vuelca no únicamente en relación con temas morales sino también estéticos, políticos y ontológicos. Para Salvatore el dandismo, en tanto actitud filosófica, recoge, en efecto, tanto el antiplatonismo nietzscheano -me refiero específicamente a la crítica nietzscheana al idealismo de Platón- como la propuesta del filósofo alemán de una transfiguración de los valores y de una revalorización del cuerpo. Asimismo, según Salvatore, el dandismo tiene su fundamento en la postura kierkeegardeana de una articulación ontológica entre lo estético, lo ético y lo espiritual. Para Salvatore, en efecto, el dandismo pone en práctica en clave laica el ideal kierkeegardiano de una articulación entre los tres estadios de la vida propios del devenir cristiano: el estético, el ético y el religioso. A partir del vínculo entre la filosofías de Nietzsche y Kierkegaard, la crítica dantista se caracteriza según Salvattore tanto por su ética nihilista y su oposición a la moral burguesa (rasgo que el dandismo debería a su vena nietzscheana) como por su comprensión unificada de lo estético -esto es, de lo referido al aspecto-, lo ético -a saber, lo relativo al comportamiento- y lo espiritual -es decir, lo relacionado con una visión de mundo(postura que el dandismo habría tomado de Kierkegaard). A partir de este planteamiento, Salvatore concluye que el dandismo se ampara en una metafísica en la cual coexisten dos rasgos primordiales: una vocación por la crítica a la moral y una afirmación del valor del cuerpo -masculino, cabe agregar- en tanto instancia de esa crítica. Así, el dandismo 
plantearía no únicamente una oposición a los idealismos afianzados en constructos supraterrenales, sino también una defensa del valor del cuerpo y de su belleza en el marco de la aspiración de hacer de la propia vida una obra de arte. El dandismo, por lo tanto, manifiesta una disconformidad con respecto al menosprecio del cuerpo así como con respecto a la moral idealista que se sigue de ese rechazo; su rebelión metafísica vendría dada, pues, por esos dos puntos de partida político/espistemológicos.

Gloria G. Durán interpreta el dandismo en esta misma dirección. Para ella, el dandi es una suerte de "rebelde intelectual" (Durán, 2010, 19). En su opinión, el trabajo ético que el dandi realiza con su propio cuerpo al acicalarse en busca de perfección se soporta en un rechazo a los ideales productivistas, así como en una "estética de la singularidad y la negación" (Durán, 2010, 14). En este sentido, el dandi, como lo apunta Echavarren, "en vez de producir para el patrón, para el sistema, se produce a sí mismo" (Echavarren, 2010, 31) -sobre este asunto véase también Sartre ([1947] 1968, 113)-. Si para inicios del siglo XIX la formalidad en el vestir se erige como sinónimo del igualitarismo democrático, el dandi aparece según Durán justamente como un personaje que utilizará su cuerpo como objeto de creación artística para oponer a esos ideales homogeneizantes un tipo de elegancia que introduce la diferencia en el aspecto como forma de rebelión. Pero ya no se trata de la diferencia tal y como la introducen las modas, sino de una diferencia portadora de disenso político. Para Durán, el dandi se rebela especialmente a

[...] cuatro grandes polaridades sobre las que se ha estructurado la normalidad burguesa: la polaridad masculino-femenino, que concibe un género estancado y clausurado biológicamente; la polaridad sujeto-objeto, que genera un yo único e idéntico; la polaridad que diferencia tajantemente lo digno y lo indigno de ser considerado como arte; y, finalmente, la que separa al "artista" de aquel que, supuestamente, no lo es (Durán, 2010, 28-29).

Pese a cierto esquematismo en el análisis de Durán, rescato de su análisis la distinción que establece entre los distintos flancos de acción propios de la crítica dandi. Según la autora, en efecto, el dandismo desborda una simple gestualidad de clase propia de una aristocracia en decadencia: el dandi emplea su cuerpo, por el contrario, como un enclave para el cuestionamiento de dicotomías metafísicas. En tal sentido, el dandismo se 
presenta para esta autora como un ejercicio estilístico a partir del cual el cuerpo es utilizado como un recurso para la disidencia en relación con las normas que rigen no solo la vida corporal, sino otras instituciones culturales como el género o las convenciones referidas al ámbito estético.

A partir de las tesis de Salvatore y de Durán es dable reconocer el cariz históricamente determinado de la rebelión metafísica de los dandis. En efecto, siguiendo a estos autores, el dandismo aparece como una ética de la negatividad y como un ejercicio de libertad que, aún enraizándose en las reivindicaciones de una cierta clase social -la burguesía-, incluyen un ethos disidente en relación con algunas de las convenciones propias de esa misma clase (especialmente aquellas referidas a los ideales productivistas y a los estereotipos de masculinidad). El estilo dandi implica, por lo tanto, una politización del aspecto y una interrogación a propósito de la relación entre las apariencias y las esencias -de ahí que quepa sostener, como lo hace Camus, que el dandi inaugura una estética que sienta las bases para ulteriores experiencias de rebeldía que involucran el cuerpo (Camus, [1951] 2008, 75)-. En esta medida, el dandi no afirma una naturaleza sino que, antes bien, afirma la necesidad de reformar la naturaleza (véase apartado siguiente). En otras palabras, la ética del dandi rechaza tanto ciertos aspectos de la moral dominante - v. gr. las referidas al trabajo y a los estereotipos de masculinidad-como el relegamiento al que dichas prerrogativas morales someten al cuerpo. El estilo dandi, por tanto, no necesariamente busca articular una deontología (de ahí el carácter variante de las prescripciones del dandismo a lo largo de su historia), sino que su norte ético, por el contrario, consiste en cuidar del cuerpo y en hacer de ese cuido -el cual, por lo demás, puede revestir diversas formas-, una vía para disenso crítico. La rebelión dandi, en esta medida, pasa por in/formar al cuerpo a partir de criterios espirituales opuestos a los ideales productivistas decimonónicos.

Tal y como me encargaré de mostrar en el próximo apartado, el dandi, en efecto, encarna una crítica de oposición: su horizonte moral consiste, ciertamente, en resistir la morfología que los ideales laborómanos establecen como obligatoria. Otra figura asociada al dandismo como Balzac afirmaba en este sentido que "la economía de 
movimiento es una manera de convertir el andar en noble y garboso [pues] la lentitud bien entendida del andar anuncia a un hombre que dispone de tiempo para sí, para el ocio" ([1833] 1998, 53). En otras palabras, mientras que los sistemas económicos reclaman cuerpos masculinos eficientes y aptos para el trabajo, el dandi se autoconstituye a partir de un cuerpo que resulta económicamente inútil en la medida de su improductividad. Mientras la normalización de los cuerpos masculinos durante el siglo XIX exigían una anatomía robusta y apta para el trabajo, el dandi afirma con su cuerpo la ociosidad y la lentitud como valores. El cuerpo dandi es, de hecho, el reverso o la negación del cuerpo obrero - de ahí que Echavarren se refiera al estilo dandi como un ejercicio de "desclasamiento" (Echavarren, 2010, 31), es decir, como una forma de renegar de a los ideales de la propia clase--. Su ética es, pues, una ética negativa, es decir, una que encarna los valores opuestos a la masculinidad burguesa y su culto hacia el trabajo (aunque se impone la necesidad de señalar que el dandi lleva a cabo esa rebelión contra el ideal del trabajo toda vez que no está confinado, como el obrero, a realizarlo). En esta línea Elizabeth Wilson se refiere al dandismo en términos de "estilo oposicional": el dandismo constituye una forma de enfrentamiento y disenso en relación con las ideas y los gustos de una mayoría considerada conformista (Wilson, 2003, 180). Es decir que se trata no de un estilo que busque agradar o conseguir adeptos, sino de uno que aspira a escandalizar y a introducir la diferencia allí donde reina lo normal. El dandi, en efecto, no cesa de producir escándalo desacatando las normas aceptadas por todos los demás.

Este carácter negativo de su ética es crucial para comprender el dandismo como una forma de rebelión y no como un disenso restringido al ámbito de la apariencia. El dandismo, de hecho, no busca ser seguido, ni busca popularizar una forma de vestir (rasgo que redunda, como veremos, en cierto culto a una rebeldía estrictamente singular); por el contrario, su objetivo crítico lo conforman los parámetros morales de época y la homologación conformista del aspecto en la que estos redundan. Camus señala en este sentido que el dandi "es por función un opositor[:] no puede asentarse sino oponiéndose" ([1951] 2008, 71). El carácter contestatario del estilo dandi, por lo tanto, obedece a una rebelión en relación con los parámetros que dictan cómo deben verse y moverse los cuerpos masculinos. En tal sentido, se pregunta Salvatore: “¿ese culto [dandi] del parecer 
(...): ¿no será acaso, sobre todo, en el fondo, una manera estética (...) de hacer desaparecer el ser mismo?" (Salvatore, [[2008] 2009, 166). La rebelión del dandi, en efecto, rechaza la subordinación del cuerpo a los ideales de la moral mayoritaria.

El estilo dandi, así, se despliega a través de una actuación que utiliza el propio cuerpo para afirmar su importancia; el estilo dantista despliega, en esta medida, una rebeldía que apunta a una crítica ontológica de los ideales formativos del cuerpo masculino, pero dicha rebeldía, de hecho, no es anterior a su despliegue corporal. La crítica del dandi, por tanto, no es solo una falla en el orden de las apariencias, sino un cuestionamiento, desde el propio aspecto, de los parámetros que normalizan los cuerpos.

\subsubsection{Los dispositivos dandis: las prendas como insumos estilísticos}

No obstante esa relación de repudio en relación con los mandatos corporales referidos a la masculinidad, la productividad y la manera normal de conducirse y de lucir, el dandi no cesa de reconocer la existencia de las normas. Su relación con las mismas es, en efecto, una relación tirante, agonística ( $\mathrm{y}$, como veremos, hasta cierto punto performativa). Para el dandi, de hecho, no se trata de desconocer la norma; se trata, por el contrario, de combatirla; el dandi es "un estudioso [de la] norma para tergiversarla en su totalidad" (Durán, 2010, 28). En otras palabras, el dandi despliega su gestualidad escandalosa e incómoda toda vez que maneja en detalle las convenciones sociales, que conoce las prohibiciones y que maneja el sentido social de lo correcto. De ahí que, como señalaba antes, los dispositivos vestimentarios del dandi no sean siempre los mismos. ${ }^{44}$ De la sobriedad de la indumentaria de Brummel hasta el excéntrico cabello teñido de verde de Baudelaire hay, de hecho, toda una gama de estrategias vestimentarias asociadas al dandismo.

\footnotetext{
${ }^{44}$ El dandismo, en tanto estilo, cuenta, grosso modo, con dos grandes tipos de dispositivos: los textuales (me refiero a obras literarias) y los indumentarios. En ambos casos el dandi busca hacer de las cosas (ya sean estas libros o prendas) pensamientos objetivados (véase respecto de este punto Sartre, [1947] 1968, 86). Sin embargo, debido a la naturaleza temática de mi investigación, acá me concentraré únicamente en los dispositivos vestimentarios.
} 
¿Qué hay, pues, en común, entre esta gama de estrategias vestimentarias de los que echa mano el dandi? ¿Cómo es que el dandi puede echar mano del excentricismo tanto como de la sobriedad en el aspecto? En primer término lo que da unidad a dichos dispositivos es su dependencia de la crítica. El dandi elige las prendas no por simple adhesión o capricho estéticos, sino porque las mismas insuflan formas críticas al propio cuerpo. En tal sentido, el dandi selecciona provisoriamente sus prendas con base a la clase de crítica que busca realizar. Así, por ejemplo, el tipo de estética corporal crítica que un dandi como Brummel desplegó en Inglaterra puede perfectamente diferir de la de un dandi francés como Baudelaire, en la medida en que las normas sociales que uno y otro personaje enfrentó difieren entre sí.

Tomemos por caso la crítica dandi al ideal laborómano a la que hice alusión más arriba. Dicha crítica, en efecto, requerirá de estéticas corporales distintas según el momento histórico del capitalismo del que se trate. Sutherland señala al respecto cómo mientras que en el caso de Brummel parecía más efectiva la adhesión a una elegancia y un porte bellos en la medida de la ociosidad que evocaban, "la crítica capitalista de Baudelaire [en cambio] será crucial para dibujar el nacimiento de un nuevo dandismo, más ideológico e intelectual que el ejercido por Brummel" (Sutherland, 2011, 18). Mientras el dandismo de Brummel pudo, pues, contentarse con ser "una expresión inteligente, estetizante y graciosa que reflejó cierto malestar ante el surgimiento de la burguesía inglesa" (Sutherland, 2011, 16), Baudelaire optó por un look más marginal que buscaba oponerse a la subjetividad del paseante propia del ciudadano de la gran metrópolis francesa. Dicho look baudelaireano podría interpretarse, por lo tanto, no como una simple incapacidad para encantar, como lo plantea Walter Benjamin ([1974] 2012, 175), sino como una estrategia para incrementar la especificidad de la crítica dandi en contraposición a una subjetividad flâneur de la que Brummel, por el momento histórico que le correspondió vivir, no necesitó distanciarse (teñirse el cabello de verde o poseer unos modos extravagantes como los de Baudelaire no son, de hecho, gestos propios de un flâneur, el cual prefiere observar a ser observado). La prenda pomposa, pero no obstante sobria a la que era propenso Brummel, o la afectación henchida de marginalidad preferida por Baudelaire, atienden, pues, a un mismo objetivo crítico - el de acusar la uniformidad 
complaciente inducida por la moral dominante-, mas las prendas para llevar a cabo dicha empresa difieren: mientras Brummel se diferencia por la vía del arreglo y la elegancia, Baudelaire prefiere efectuar su crítica a través de la rareza. En otras palabras, lo común a ambas formas de crítica es el disenso corporal que involucran mas no el modo en que dicho disenso se lleva a cabo. Cada dandi de la historia, por otra parte, incluirá los dispositivos vestimentarios que le parezcan más eficientes para tales efectos (piénsese en la extravagancia de Wilde o en el propio Barbey D`Aurevilly y su aspecto desaliñado), introduciendo así matices significativos en el estilo dandi. Pero lo que permanecerá a lo largo del tiempo a pesar de estas variantes es esa profunda ligazón entre los dispositivos indumentarios y la crítica. En primer lugar, por tanto, los dispositivos vestimentarios del dandi se caracterizan por su puesta en escena, siempre mediante el cuerpo vestido, de críticas situadas.

En segunda instancia, el estilo dandi echa mano de dispositivos indumentarios como parte de un conjunto de "ejercicios espirituales" o bien como parte de una particular forma de ascetismo -sobre el ascetismo dandi véase Camus ([1951] 2008, 71)-. En este sentido, como lo apuntala el filósofo Daniel Salvatore, el dandismo -el autor se refiere especialmente al baudelaireano, aunque creo posible hacer coextensible su comentario al dandismo en general- lleva a cabo "una puesta en relieve de la dimensión espiritual del aseo y [el] acicalamiento" (Salvatore, [2008] 2009, 163) -el cual, como acabo de señalar, no debe confundirse con simple limpieza sino que debe entenderse como una disposición a prestar atención al aspecto; en otras palabras, el acicalamiento del dandi pueden perfectamente estar al servicio de una apariencia desaliñada o marginal- . Según este autor, dicha dimensión se basa en una suerte de monismo: el dandi, mediante el acicalamiento, pone en práctica la premisa de una unidad constitutiva entre el espíritu y el cuerpo (Salvatore, [2008] 2009, 174). El dandi cuida de sí en un sentido foucaultiano; esto es, lleva a cabo una serie de operaciones de acicalamiento corporal (maquillaje, peinados o arreglo en la corbata) cuyo objetivo es proyectarse en el espacio público como alguien que gobierna de sí mismo. La atención referida al aspecto o más precisamente al look deviene así ejercicio subjetivante; se trata de un ejercicio de estilo a través del cual el dandi no solo vigila su aspecto sino que intenta producirse a través de él. El aspecto, 
en esta medida, se convierte en un ámbito material para el ensayo, en materia prima inestable con la cual es dable experimentar.

Este trabajo del dandi sobre sí mismo constituye, según Salvatore, el corazón mismo del dandismo. Así es como aparece en repetidas ocasiones, en el interior del estilo dandi, toma fuerza la idea (luego retomada por las vanguardias artísticas de la modernidad, particularmente por el dadaísmo) del cuerpo como obra de arte viviente. ${ }^{45}$ Las prendas juegan en este sentido un papel fundamental. De hecho, prenda y cuerpo, en consonancia con ese monismo de cuerpo y alma al que hacía alusión más atrás, conforman una unidad. Así, no es la prenda la que hace al estilo, sino que el estilo constituye una forma de in/corporar la prenda: "¡No es un atuendo que camina solo! [exclama Barbey D`Aurevilly] por el contrario, es una cierta manera de portarlo lo que crea el dandismo. Se puede ser dandi con un traje arrugado" ([1845] 2008, 22). En la misma línea que su antecesor dandi, Baudelaire señala que "las modas, si se las quiere gozar plenamente, no deben ser consideradas como cosas muertas; sería como admirar los harapos suspendidos, flojos e inertes como la piel de San Bartolomeo, en el armario de un prendero. Hay que figurárselas vivas" ([1862] 1995, 123-124). Así, pues, la prenda provee al dandi un insumo para la transformación de su cuerpo; pero a la vez, al ser in/corporada, la prenda altera las posibilidades de ese mismo cuerpo y le provee nuevas "funciones". El dandismo, en este sentido, desmiente el lugar común de la prenda como simple elemento semiótico. El cuerpo vestido, en efecto, no es para el dandi una máquina significante como lo creía Barthes (véase al respecto el apartado 1.4.), sino una especie de elemento "anexable" (tal y como lo diría Merleau-Ponty) que le otorga al cuerpo nuevas posibilidades. Esto es: la cuestión respecto del cuerpo vestido para el dandi no es qué significan las prendas, sino cómo funcionan, cuál es su eficacia crítica. A la luz del dandismo se podría decir, de hecho, que lo verdaderamente relevante a propósito del

\footnotetext{
${ }^{45}$ Este tema del cuerpo como obra de arte es objeto de un explícito interés en una de las novelas clásicas dentro de la tradición dandi: El retrato de Dorian Grey ([1890] 1999), de Oscar Wilde. Sobre la relación, por otra parte, entre el surrealismo y la vestimenta, véase Moda y surrealismo (2001), donde François Baudot analiza el modo en que dicha vanguardia echó mano de las prendas como materia prima para sus trabajos artísticos. Sobre los derroteros de esta concepción de la obra de arte como fuente de crítica en el caso de las posvanguardias véase el trabajo del teórico argentino José Amícola (2000).
} 
vestido, al menos en su faceta política, es qué consecuencias tiene a nivel social su uso y no qué significados comunica una determinada prenda.

Dado que el cuerpo del dandi aspira siempre a la exhibición, la prenda también es empleada a la manera de un dispositivo performativo. En esta línea, Gloria Durán advierte cómo los dandis "transformarán cada gesto cotidiano en una expresión de su artisticidad promoviendo cierta protohistoria de la performance" (Durán, 2010, 22). La proyección en el espacio público de una crítica política corporal está mediada, por lo tanto, por un impulso creador que hace parte de una búsqueda de perfección espiritual. En tal sentido, como lo señala Gloria Durán, el dandi "logrará (...) con su performatividad cotidiana definir (...) un modo de exhibicionismo que cita la norma para ponerla 'patas arriba"' (Durán, 2010, 29). En suma, una segunda característica del dispositivo vestimentario dandi es su inscripción dentro de un conjunto de operaciones ascéticas cuyo objetivo es la conversión del propio cuerpo en obra de arte para su ulterior exhibición pública.

En tercer lugar, en el estilo dandi la indumentaria y los accesorios se utilizan como parte de una crítica al ideal del cuerpo como entidad natural. En el espíritu de las observaciones que realicé en el capítulo 2 de este trabajo en relación con el carácter eminentemente social de la corporalidad, para el dandismo el cuerpo es una superficie de intervención permanente y no una superficie biológicamente determinada. Esto queda particularmente claro en el elogio del maquillaje realizado por Baudelaire en su obra $E l$ pintor en la vida moderna ([1862] 1995). Para Baudelaire, mientras "el crimen es originariamente natural (...) la virtud, por el contrario, es artificial" ([1862] 1995, 122). Esta pertenencia de la ética al ámbito de lo artificial o, para decirlo con lenguaje contemporáneo, esa visión construccionista de lo moral, desemboca en una visión sumamente particular acerca del artificio corporal y de la importancia del maquillaje. Según Baudelaire, el dandi debe apelar al atavío toda vez que es necesario reformar la naturaleza y terminar con la idea de que esta constituye un factor determinante de lo social. La prenda, por tanto, no se limita a adornar, sino que por el contrario constituye un insumo técnico que se funde con el cuerpo para dotarlo de una artificialidad que lo 
faculta para realizar el cometido de superar críticamente la naturaleza. La indumentaria y el acicalamiento se revelan, en este sentido, como instrumentos para la crítica a la visión medieval del maquillaje según la cual la excesiva vanidad es una forma de renegar de la propia constitución y de los propios rasgos asignados por Dios -véase Salvatore ([2008] 2009, 165)-. Sin embargo, en último término, hacia lo que se dirige la argumentación baudelaireana es a realizar una apología de la autogestión corporal. La dicotomía, tal y como la dibuja Baudelaire, no consiste en optar ya sea por la vanidad, ya sea por permitirle al cuerpo que asuma la morfología que se le presume connatural; más bien, para el poeta, la dicotomía que abre el maquillaje consiste en oponer la postura de quien por un lado abandona su cuerpo (es decir, quien lo deja ser conforme a su naturaleza), y la de quien, por otro lado, asume la tarea de gestionarlo. En tal sentido, el estilo dandi dista de ver en la prenda un elemento de consumo: de lo que se trata para dicha figura, más bien, es de entender el cuerpo como el sitio de una batalla y la prenda como una arma para llevarla a cabo. Foucault señala al respecto cómo en El pintor en la vida moderna ([1862] 1995) el héroe baudeleaireano, lejos de asumir la actitud observadora del flâneur, prefiere la actitud de quien "a la hora en que el mundo entero abraza el sueño, (...) se pone a trabajar y lo transfigura” (Foucault, [1984] 2010c, 982-983, subrayado mío). El dandi, pues, es un transfigurador del mundo y de su propio cuerpo, y así como el artista arquetípico para Baudelaire es el pintor que no se contenta con imitar el mundo en su arte sino aquel que busca transformarlo, asimismo el dandi es aquel que altera su cuerpo por medio del maquillaje. En tercer término, por lo tanto, el maquillaje y el adorno constituyen para el dandi insumos estilísticos para combatir la alienación corporal introducida por la naturaleza. El atavío del dandi, por tanto, es un instrumento que lo faculta para la autogestión corporal.

Estos tres elementos (la propensión a un uso estratégico -en tanto situado- de la prenda, la visión de la ropa como elemento técnico que hace parte de un ascetismo transformador del propio cuerpo en obra de arte y, por último, el elogio de las prendas y el maquillaje como forma de autogestión corporal) reflejan el papel que el dispositivo vestimentario ocupa dentro del estilo dandi. Como es manifiesto, el dandismo se aleja de aquel uso disciplinado del vestido que describí en la segunda parte de este trabajo. El dandi, en 
suma, dista de ser una víctima pasiva de la moda; dentro de su ethos la ropa constituye un insumo de la crítica y no un dispositivo que enviste unilateralmente el cuerpo.

\subsubsection{Los límites del estilo dandi: el culto a la singularidad y el asunto de las mujeres}

Aunque algunos autores tienen interés en considerar el dandismo como una tradición no exclusivamente conformada por varones, lo cierto del caso es que los dandis históricamente se han identificado como tales. Particularmente la ya mencionada Gloria G. Durán, en su Dandysmo (sic) y contragénero (2010), argumenta que si lo propio del dandismo es una actitud autocreadora y una forma de crítica a los ideales normalizadores del cuerpo, entonces es factible indagar la historia en busca de mujeres dandis. En concreto, Durán señala que en el período de entreguerras surgen una serie de personajes (como las escritoras Elsa Von Freytag-Loringhoven y Djuna Barnes, o las artistas plásticas Florine Stettheimer y Romaine Brooks) cuyas biografías podrían ser reconstruidas a partir del dandismo como clave interpretativa.

Ciertamente, como ya lo he indicado, el dandismo es una tradición abierta, que admite negociaciones respecto de su sentido y de sus características, por lo cual la tesis de Durán no resulta inviable. No obstante, considero que visto dentro de una perspectiva histórica más vale pensar en los disensos corporales de los que habla esa autora como formas de estilo feministas, toda vez que dichas mujeres manifiestan con sus gestos antes una voluntad de crítica a la desigualdad sexual y las jerarquías que se siguen de la misma, que un deseo de adherirse al dandismo.

Lo que sí es cierto es que en el dandismo existe una interrogación a propósito de lo que Gabriela Castellanos define como "generolectos", es decir, el tipo de gestos que se consideran apropiados según la previa asignación de una identidad y orientación sexuales 
(Castellanos, 2006, 27-35). ${ }^{46}$ Los dandis, de hecho, son tachados a menudo de afeminados y/o afectados. Su gestualidad no calza con el tipo de ademanes que le corresponderían a un varón según los cánones sociales. En ese sentido, Durán detalla cómo el dandi, al autoimponerse un estilo disidente, enfrenta

[...] tanto al "dispositivo de masculinización" como al "dispositivo de feminización". El centro de la diana de todo el sistema del dandysmo [sic] no será otro que el orden burgués, la distinción misma de la apropiada feminidad y la apropiada masculinidad es uno de los pilares básicos del orden burgués. ¿Cómo no comenzar derrocándolo? $(2010,49)$.

Los dandis, ciertamente, confunden con su gestualidad. Como parte de su estilo provocador asumen ademanes no ajustados a las expectativas sociales respecto de lo masculino. En tal sentido, Barbey D 'Aurevilly describe a los dandis como

[...] naturalezas dobles y múltiples, de un sexo intelectualmente indeciso, en los que la gracia es aún más gracia en la fuerza y en los que la fuerza también se encuentra en la gracia, andróginos de la Historia, no ya de la fábula, y de quienes Alcibíades fue el ejemplo más bello en la más bella de las naciones ([1845] 2008, 70).

Sartre, por su parte, menciona en varias ocasiones la deliberada actitud provocadora de Baudelaire al pasearse públicamente evitando de puntillas los charcos y el barro, luciendo guantes rosados y haciendo gala de toda una coquetería y una vanidad que su época solo podía asociar a las mujeres (Sartre, [1947] 1968, 122-124). Brummel, por su parte, si bien más acorde con la imagen de la masculinidad de su período histórico, también renegó de instituciones típicamente asociadas a lo masculino, como por ejemplo el ejército, al que repudiaba por su uso del uniforme, y del que finalmente desertó alegando que no deseaba alejarse del Príncipe de Gales (D`Aurevilly, [1845] 2008, 41) -el mismo al que más tarde dirigiría las burlas a las que hice alusión con anterioridad-. La bisexualidad de algunos dandis como Oscar Wilde, también puede ser considerada en esta clave de desacato al disciplinamiento del género y a la normalización del cuerpo y la sexualidad.

\footnotetext{
${ }^{46}$ Sobre la noción de "generolectos" y la forma en que estos han sido objeto de normalización a través de la moda véase el tercer capítulo de este trabajo.
} 
Pero tanto esas rupturas dandistas en relación con la normalización de la sexualidad como el aspecto hasta cierto punto andrógino del dandismo al que se refiere D`Aurevilly no se deben sobredimensionar (el tema de lo andrógino será objeto de atención en el capítulo siguiente). De hecho, existe en el dandismo una misoginia difícil de negar. Al lado de esa propensión a oponerse a lo que en esta investigación he llamado disciplinamiento vestimentario, en el dandismo coexiste una tendencia a conservar una serie de ideologemas relacionados con el género, a saber: una serie de constructos no problematizados que funcionan a la manera de un telón de fondo conformado por significados y prejuicios sedimentados. ${ }^{47}$ Así, por ejemplo, Baudelaire habla de la mujer como un "bello animal" ([1862] 1995, 118) y Barbey D`Aurevilly se extiende en sus consideraciones respecto de cómo el modelo de cortejo propio del dandismo incluye un repertorio de acciones de desprecio e indiferencia hacia la mujer enamorada ([1845] 2008)71-91). Por otra parte, Sartre señala que aún cuando el dandismo incluye una cierta apropiación de rasgos femeninos, no es claro que esa apropiación de la feminidad sea en clave crítica. Para Sartre, la feminidad imaginada por los dandis es la propia de la mujer ociosa y burguesa: cuando el dandismo considera deseable incorporar la feminidad dentro de su conjunto de gestos lo hace porque identifica estereotipadamente a la mujer con la tendencia a ataviarse para el resto y con la predisposición a depender de la opinión de los demás (Sartre, [1947], 1968, 127). ${ }^{48}$ Del mismo modo, Benjamin observa que aún el ideal heroico de la mujer lesbiana propio de algunos de los poemas de Baudelaire es presentado por dicho autor como una conjugación del ideal masculino, entendido como belleza decidida y fuerte, con la animalidad propia, según el poeta, del género femenino (Benjamin, [1974] 2012, 169-170). En otras palabras, los dandis parecieran ciertamente críticos respecto de la normalización del cuerpo masculino (en razón de lo cual adoptan para sí "generolectos" femeninos), pero no parecieran demasiado dispuestos a ser igualmente críticos con el disciplinamiento de los cuerpos clasificados como femeninos. En síntesis: el estilo dandi, pese a su tendencia crítica respecto de la masculinidad decimonónica, conserva núcleos binaristas jerarquizados y jerarquizantes.

\footnotetext{
${ }^{47}$ Sobre la noción de ideologema en el universo del análisis textual -del cual proviene originalmentevéase Kristeva ([1969] 2001, 148).

${ }^{48}$ A propósito del modo en que el estilo feminista retoma críticamente ese imaginario del cuerpo femenino como un cuerpo dispuesto para su contemplación masculina, véase el apartado 6.2.5.
} 
El dandi, en ese sentido, cuestiona el disciplinamiento de género, pero su cuestionamiento tiene un alcance limitado. Hay, en definitiva, un interés por mezclar los géneros y una cierta atracción por la androginia, pero no se llega a interrogar directamente el género en tanto matriz de individuación. El dandi mezcla los géneros, mas no aspira a criticar la propia matriz generizante que los hace posibles. En otras palabras, al centrarse en la crítica a uno solo de los polos propios del binarismo sexual -el masculino-, el dandi no considera la posibilidad de una crítica al binarismo en sí. El dandi, en suma, quiere escapar a la normalidad, confronta con su crítica las morfologías disciplinadas, pero en su relación con el núcleo dicotómico de género que las origina se combinan el rechazo a los dispositivos de masculinización y la conservación de ciertos elementos del binarismo sexual con carga patriarcal.

Esta acriticidad dandi respecto de la forma en que la moda disciplina el cuerpo femenino y la idealización dandi de "lo" femenino no es, sin embargo, la única frontera crítica de este estilo. El potencial disruptivo del dandismo posee, de hecho, otro rasgo problemático que le pareciera igualmente consustancial. Me refiero a su exagerado culto a la singularidad. Si bien, como lo señala Roberto Echavarren, la eficacia política del dandismo se deriva, en parte, de esa propensión a introducir la singularidad allí donde la moda intenta homologar (Echavarren, 2010, 32-33), lo cierto del caso es que esa fidelidad a lo diferente también redundó, en ciertos casos, en inoperancia política. Si el gesto ético por excelencia del dandi consiste en estilizar el propio cuerpo individual dándole unos rasgos completamente particulares y dotándolo de una actitud única frente a la masa, entonces el dandi pareciera condenado a concebirse a sí mismo como un sujeto solitario. Contrariamente a lo señalado por Barthes, para quien el fracaso del dandismo se encuentra determinado por la capacidad de la moda de imponerle al dandi la serialidad allí donde este pretendía hacer reinar lo singular (Barthes, [1962], 2003, 408), considero que los alcances críticos del dandismo se vieron limitados por las propias incapacidades del dandismo para erigirse como alternativa colectivo. El carácter eminentemente negativo de la ética dandi al que ya he hecho alusión no es, de hecho, incompatible con la articulación de un sujeto colectivo. Por el contrario, como lo indiqué en el capítulo 
anterior, el contenido de una crítica opositiva tiene tanto más fuerza cuanto más consigue imponerse en el espacio público, lo cual, por lo demás, está directamente relacionado con la posibilidad de trascender la disidencia estrictamente individual. El estilo dandi, pues, sin duda posee una cierta eficacia a la hora de cuestionar las normas corporales masculinas, pero el carácter localizado de esa crítica deja por fuera el binarismo sexual en tanto matriz de individuación que produce también cuerpos femeninos disciplinados.

Esto resulta paradójico cuando se repara en el carácter abiertamente estratégico del dandismo y en su maleabilidad a la hora de pasar de una forma de crítica vestimentaria a otra (por ejemplo del excentricismo a la simplicidad, o bien de esta a la elegancia). Precisamente porque el dandismo conoce de estrategia resulta extraña esa dificultad para generar una comunidad crítica. Sin embargo, existe un cierto consenso en torno al hecho de que esa dificultad existió.

Walter Benjamin, por ejemplo, muestra cómo en Baudelaire convive lo que el autor alemán denomina con Marx una "metafísica de la provocación" (es decir una propensión casi visceral a hacer parte de cualquier revuelta -se trata, grosso modo, de lo mismo que acá he denominado la actitud crítica dandi-) con esa heroicidad solitaria que encuentra dificultad en establecer vínculos sociales con otras formas de rebeldía (Benjamin, [1974] 2012, 174). El dandi, sin duda, tiene ancestros y con suerte quizá tenga sucesores, pero en raras ocasiones tiene contemporáneos. A lo sumo posee simpatía hacia otros marginales como los "bandidos y los fuera de la ley" (Salvatore, [2008] 2009, 146), pero más allá de esa identificación esporádica con otras expresiones de anomalía, el ethos dandi pareciera renuente al establecimiento de vínculos.

De hecho, el dandi conserva siempre una renuencia a fundirse con la multitud; aún más: ese pareciera ser el núcleo central de su actitud. Esto queda en evidencia en la posición de Baudelaire frente a las multitudes subrayada por Benjamin y expresada a través de la diferencia entre el dandi y el flâneur. Mientras que este último, en efecto, opta por vagar por la ciudad y confundirse con las multitudes, aquel conserva una distancia crítica irrenunciable en relación con estas. Para Baudelaire, sostiene Benjamin, "ya no existía 
(...) el brillo de esa multitud movida por sí misma, animada en sí misma, que embelesaba al flâneur (...). Baudelaire lucha contra la multitud; lo hace con la cólera impotente de aquel que lucha contra la lluvia o el viento" (Benjamin, [1974] 2012, 240-241). Toda vez que el flâneur va en busca de lo nuevo y el dandi en cambio no cree en el progreso, este último personaje renuncia a articular sus críticas colectivamente, con lo cual su disidencia singular pierde algo de su eficacia estratégica.

El autor que quizá ha reparado en este asunto con mayor agudeza es Jean Paul Sartre. En su libro sobre Baudelaire, Sartre explica cómo la disidencia baudelaireana se resuelve en "una integración (...) mítica en una sociedad que sea como una réplica de la aristocracia desaparecida (...). Esta sociedad discreta, formada en su mayor parte por difuntos y niños por nacer, es completamente satisfactoria para el artista" (Sartre, [1947], 1968, 127), en la medida en que allí la acción común aparece como innecesaria, resultado de la pertenencia hasta cierto punto arbitraria a una estirpe que, como indiqué al inicio de este capítulo, es ciertamente difusa. En tal sentido, para Sartre el dandismo, en tanto colectivo, está conformado por una comunidad de muertos. He aquí, pues, una segunda limitación crítica del dandismo: allí donde el dandi individual alcanza lucidez crítica topa con un exagerado culto a la singularidad que no le permite articular una disidencia de carácter colectivo de la cual bien podría haber obtenido una mayor fuerza política. De tal modo que, como concluye Sartre, "este solitario que teme a la sociedad solucionó la cuestión de las relaciones sociales imaginando mágicas formas de participación entre seres aislados, la mayoría de los cuales están muertos” (Sartre, [1947], 1968, 121).

Aún con estas limitaciones señaladas como propias del dandismo no se trata, sin embargo, de decretar la validez o invalidez de dicho estilo. Me parece, de hecho, que si se repara en el carácter abierto de los estilos, es decir, en su condición de repertorio gestual siempre permeable al cambio, calificar un ejercicio crítico como legítimo o ilegítimo implica evaluar un cierre que en verdad no ha tenido lugar. Según creo, resulta más provechoso, en cambio, realizar un balance crítico que permita comprender los diferentes ejercicios estilísticos en toda su complejidad y con todo y sus pugnas y paradojas internas. De hecho, creo que los límites críticos que he señalado como propios 
del dandismo son de hecho enfrentados a la manera de desafíos por el estilo feminista. Los estilos, en esta medida, no tienen porqué enfrentar la normalización del cuerpo en solitario. Eso, en parte, es lo que intentaré mostrar a continuación.

\subsection{El estilo feminista}

En esta sección analizaré una segunda expresión histórica de estilo. Me refiero al feminismo. Siendo que, como mostraré, el feminismo trasciende sus expresiones teóricas y posee, en tanto movimiento político, un carácter "aletúrgico", intentaré pensar la dimensión estilística propia de los movimientos de mujeres. Dado que una reconstrucción del estilo feminista como un todo desbordaría los límites de este estudio, me ocuparé sobre todo de algunos episodios históricos en los que la implementación de vestimenta es particularmente manifiesto. En primera instancia, por tanto, discutiré la validez de pensar el feminismo, allende su dimensión teórica, como una forma de estilo. Para ello, intentaré mostrar la viabilidad de una interpretación histórica del feminismo en el que el cuerpo y su uso crítico ocupen un lugar central. En el segundo apartado, intentaré destacar algunas de las características centrales del estilo feminista. Especialmente me centraré en el vínculo del estilo feminista con la cuestión del reconocimiento y del ensanchamiento de los parámetros de reconocibilidad, en el escándalo como forma de visibilización de las problemáticas de las mujeres y en la recurrencia feminista a las prendas como un modo de acceder a ciertos espacios reservados para los varones. Por otra parte, en el tercer apartado procederé a leer como formas de estilo algunas de las luchas históricas de las mujeres en búsqueda de ampliar su rango de movimiento. Dentro de esa línea, interpretaré los movimientos reformistas del traje así como la apropiación feminista de la indumentaria deportiva como ejercicios históricos de estilo. En cuarto lugar analizaré, a través del ejemplo del movimiento sufragista, los ejercicios de estilo feministas vinculados a la búsqueda de reconocimiento y a la apropiación del espacio público. Por último, discutiré el contenido estilístico involucrado en el rechazo feminista de las técnicas de embellecimiento, tal y como estas se conciben desde los regímenes de disciplinamiento vestimentario. Se trata, por lo tanto, de leer el feminismo como una ética 
del cuerpo y como un modo de militancia parrhesiástica en el que las jerarquías de género son puestas en entredicho. En otras palabras, mediante el examen del feminismo como una forma de estilo, me interesa destacar el ethos crítico propio de los movimientos de mujeres.

\subsubsection{El feminismo en cuanto estilo}

Sin duda, analizar el feminismo en términos de estilo indumentario no solo no constituye un procedimiento teórico común, sino que además se trata de un procedimiento que involucra distintas épocas y corrientes. En la bibliografía dedicada a la vestimenta, la relación entre el feminismo y la moda suele caracterizarse, de hecho, de forma un poco apresurada como una relación hostil (al respecto véase Wilson, 2003, 229-230). No obstante, tal y como lo señala Butler a partir de su crítica a la visión del género como una esencia, "los cuerpos con género son (...) 'estilos de la carne' ['styles of the flesh']. El género es un estilo corporal [a corporeal style], un acto, por así decirlo" (Butler, [1990] 2007, 271). Entender el género como algo que se hace con el cuerpo (como señalé en el capítulo anterior, no sin una serie de condicionantes sociales que vienen dados por la historia y la cultura) implica entender asimismo el feminismo como una forma de interrogar críticamente el modo en que cada época define ese hacer. En tal sentido, Butler deja entrever que el feminismo plantea modos alternativos de entender y vivir el género; los horizontes críticos del feminismo abarcan, pues, en su opinión, maneras estilizadas de ocupar la categoría mujeres.

Mi tesis, partiendo de Butler, es que dentro de esas maneras alternativas de hacer el género las prendas tienen un lugar relevante. En otras palabras, si el género es algo que se hace con el cuerpo, y si, como lo señalé en el segundo capítulo, cuerpo y vestimenta conforman una unidad indisoluble, la crítica de género, por lo tanto, puede involucrar elementos de estilo. Si bien Butler conceptualiza ese cruce entre el estilo y el género (Butler, [1990] 2007), hay que advertir que tal cruce no ha sido incorporado en demasiadas ocasiones en las teorizaciones más recientes sobre moda (una excepción la 
constituyen los análisis de la teórica australiana Wendy Parkins, de los cuales me ocuparé más adelante). Antes bien, como decía supra, existe cierta tendencia a perfilar la relación entre el feminismo y la indumentaria estilizante como una relación hostil.

Esta visión según la cual el feminismo posee una postura de sistemática enemistad hacia el vestido involucra al menos dos confusiones. Por un lado, implica asumir que el feminismo rechaza por igual una utilización crítica de la indumentaria que una utilización disciplinada de la misma. Por otro, supone partir del feminismo entendido de forma restrictiva como el conjunto de reflexiones teoréticas sobre las desigualdades de género, excluyendo así de dicha categoría las luchas sociales que buscan revertir esas desigualdades. En este apartado deseo revisar esos dos malentendidos en aras de allanar el camino para comprender el feminismo como un ejercicio crítico de estilo.

En primer lugar cabe señalar que la teoría feminista no posee una visión monolítica sobre el vestido. Mientras que textos de autoras feministas clásicas como Virginia Woolf o Simone de Beauvoir contienen ciertamente algunos señalamientos críticos sobre el impacto de la vestimenta en la construcción social de los géneros -véase por ejemplo Woolf ([1938] 1999, 33-39) y Beauvoir ([1949] 1987, 812-814)-, otras autoras contemporáneas consideran la vestimenta como un instrumento útil dentro de la causa feminista -así, por ejemplo, en el caso de teóricas que retomaré más adelante como la historiadora francesa feminista Christine Bard o la ya mencionada Wendy Parkins-. De todas maneras, como lo señala Elizabeth Wilson, las posiciones hostiles hacia la moda dentro del feminismo tienen que ver antes con una crítica al modo en que la industria de la moda ha generado estereotipos relacionados con la belleza y ha construido el cuerpo femenino como objeto de comercio sexual, que con una hostilidad hacia las prendas propiamente dichas (Wilson, 2003, 230).

En el capítulo anterior, por otra parte, he argumentado que varias teorizaciones feministas podrían ser leídas, mediante un ligero desplazamiento interpretativo, como especulaciones sobre la cuestión del estilo en conexión con las problemáticas de las mujeres. En una palabra, considero que si el feminismo ha mantenido una postura de 
sospecha hacia la indumentaria, esa posición ha estado dirigida antes a la utilización disciplinante de la misma, que a la vestimenta en cuanto tal. De hecho, los movimientos de mujeres, como tendré posibilidad de mostrar más adelante, han llevado a cabo, cuando lo han juzgado conveniente, ejercicios críticos de estilo como parte de su repertorio de acciones políticas.

Esto nos lleva al segundo malentendido al que hice referencia antes. Me refiero a la propensión a escindir la militancia feminista de la producción teórica feminista. ${ }^{49}$ A la hora de analizar el vínculo entre la moda y el feminismo, esa propensión redunda en un simplificado esquema en el cual la vestimenta pareciera un tema sin importancia para el feminismo. En ese esquema (véase a manera de ejemplo Monneyron, [2005] 2006, 7479), la relación entre moda y feminismo se restringe unilateralmente al examen de los escasos textos feministas que abordan dicha relación, desconociéndose, o relegándose a un segundo plano, las abundantes apropiaciones estratégicas que las mujeres han llevado a cabo de ciertos dispositivos vestimentarios. No obstante, si se comprende el feminismo como un aparato crítico destinado tanto a deconstruir como a combatir mediante una cierta praxis los mecanismos a través de los cuales se configuran, perpetúan y sostienen las desigualdades de género, no hay duda de que esa supuesta desconfianza del feminismo hacia la indumentaria se vuelve cuando menos una premisa improbable. Desde los movimientos sufragistas y hasta los movimientos reformistas del vestido, varias agrupaciones feminista, como mostraré en los siguientes apartados, han comprendido históricamente el carácter estratégico de la vestimenta en tanto dispositivo de gobierno de los cuerpos de las mujeres y han librado, por ende, batallas en ese campo en búsqueda de autonomía corporal.

Frente a las artimañas de la moda, pues, distintos movimientos feministas no se han contentado con atacarlas, sino que han hecho uso de las propias prendas como un mecanismo de contestación. Si, como lo señala Wendy Parkins, no hay agencia feminista sin cuerpo -y si ese cuerpo, como lo señala la propia autora, es de por sí un cuerpo

\footnotetext{
${ }^{49}$ Una sugerente reflexión sobre el modo en que se entrelazan la teoría y la práctica feministas puede verse en Butler ([1990] 2007, 19-20).
} 
vestido $(2009,60-62)$ - creo, pues, que cabe entender el feminismo no solo como una teoría sino también, a la manera de Butler, como un estilo, es decir, como una praxis política que incluye ejercicios de crítica corporal. Puesto que dentro de la amplia agenda feminista los movimientos de mujeres han incluido históricamente una reflexión a propósito del carácter político de la vida privada, y en consecuencia han integrado dentro de sus reivindicaciones el derecho a autogestionar sus cuerpos, creo que es viable, pues, analizar el modo en que estos elementos críticos han sido desplegados a través de estilos indumentarios. En consecuencia, consideraré a continuación algunos episodios históricos de las luchas de mujeres a partir de la noción de estilo.

\subsubsection{El cuerpo vestido como herramienta crítica: algunas características del estilo feminista}

Al igual que en el caso del estilo dandi, los estilos feministas no son monolíticos ni se agotan en conjuntos de reglas vestimentarias. Por el contrario, los movimientos feministas han dejado en claro que poseen un gran sentido de la oportunidad, desplegando tácticas que han abarcado gestualidades diversas según el momento histórico del que se trate. En este sentido, la variabilidad de los ejercicios críticos de estilo propios del feminismo obedece al carácter siempre situado de sus lecturas políticas. Los estilos feministas, en otras palabras, mutan con la historia.

No obstante ese carácter cambiante del estilo feminista, algunos rasgos podrían destacarse como propios del mismo. En primer lugar, dentro de dicho estilo - con todo y las múltiples versiones que este ha conocido a lo largo de la historia- existe una preocupación por el propio cuerpo y por el modo en que sobre él se despliegan tácticas en aras de domeñarlo. Esto es: dentro del estilo feminista, tal y como lo señalé antes, existe una conciencia del carácter político de la vestimenta y de sus usos disciplinantes. A sabiendas de que la vestimenta se utiliza no solo para inscribir los cuerpos dentro de grillas de inteligibilidad binarias, sino además como un modo de rechazar ciertas morfologías corporales como impropias (véase el tercer capítulo de este trabajo), un 
primer rasgo del estilo feminista es su tendencia a reaccionar críticamente a estas operaciones mediante acciones colectivas. Mientras que el estilo dandi es propenso, como ya lo he señalado, a rendir un exagerado tributo a la singularidad, los ejercicios de estilo feministas, en cambio, tienden a desplegar sus acciones colectivamente. No obstante que el acicalamiento pareciera a primera vista un acto privado, la utilización politizada que del mismo han hecho en ciertos momentos de la historia las mujeres como colectivo dista de restringirse a esa esfera de lo privado: el atavío ha representado para las feministas, de hecho, un recurso para la politización del propio cuerpo a la hora de presentarlo en público. Este carácter colectivista del estilo feminista, implica, además, que los gestos estilísticos feministas muchas veces se dan de forma transversal en la historia. Me refiero al hecho de que un mismo núcleo estilístico o una misma reivindicación crítica pueden pervivir en el tiempo más allá de las mujeres que los impulsaron inicialmente (razón por la cual en el análisis que desarrollaré en las páginas siguientes no seguiré un orden estrictamente cronológico). Así, mientras los ejercicios de estilo dandis eran llevados a cabo por individuos aislados que no perduraron en el tiempo, el estilo feminista tiende a organizar acciones más bien conjuntas que atraviesan la historia transversalmente. Esto no implica, sin embargo, que los estilos feministas estén comprometidos necesariamente con el binarismo de género. De hecho, como veremos, el estilo feminista abarca tanto gestualidades subjetivantes (esto es, que buscan producir identidad) como desubjetivantes (es decir, gestualidades que procuran desmarcarse de identificaciones normalizadas), ${ }^{50}$ por lo que cabe pensar en la feminidad propia del estilo feminista como un rasgo inestable o en todo caso sometido a variaciones históricas.

Un segundo rasgo del estilo feminista viene dado por su recurrencia al escándalo como modo de visibilizar las problemáticas de los cuerpos clasificados como femeninos. Toda vez que la crítica tal y como la conceptualicé en el capítulo anterior consiste, en parte, en hacer irrumpir lo impropio como un modo de develar el carácter contingente de las normas, el estilo feminista abarca técnicas corporales que producen un tipo de corporalidad femenina que atenta contra los paradigmas normalizadores que dictan qué es

\footnotetext{
${ }^{50}$ Sobre el concepto de identificación véase De Lauretis ([1989] 1996, 20-21); sobre el concepto de desidentificación véase Preciado (2007, 122-126). Sobre la viabilidad estratégica de combinar tácticas identificatorias y desidentificatorias, véase Preciado (2005, 161-163).
} 
un cuerpo de mujer. El escándalo es un recurso que reclama reconocimiento. Así, el estilo feminista incluye una amplia gama de dispositivos estilísticos de género que buscan corroer los arquetipos epocales de feminidad y compeler a los discursos hegemónicos a negociar respecto del sentido otorgado a la categoría "mujeres" -sobre el carácter táctico que la categoría "mujeres" detenta para el feminismo véase Butler ([1993], 2008, 55)-. Por otra parte, el escándalo y la ironía en tanto métodos de provocación requieren, para ser eficaces, de una cierta teatralización o puesta en público. El estilo feminista, por ello, es también un modo crítico de conducirse en sociedad: un modo contestatario de encarnar la feminidad. Pero toda vez que la crítica feminista ataca la dicotomía publico/privado, el estilo feminista incluye, además, un ensanchamiento, mediante el uso del cuerpo, de la noción de lo público. Wendy Parkins señala al respecto cómo el cuerpo político entendido según la época como la representación material ora del Estado ora de lo comunitario- al no haber estado exento de una cierta generización, se ha visto obligado a cobijar cada vez más, como resultado de una buena cantidad de luchas feministas, a las mujeres como parte de sí (Parkins, 2002a, 3). En tal sentido, la recurrencia al escándalo constituye un ejercicio de estilo feminista que posiciona en el dominio común la interrogante de cuáles son las exclusiones que pone en juego nociones como lo público, lo universal o la ciudadanía.

Finalmente, un tercer rasgo de la actitud crítica feminista viene dado por su rechazo a las constricciones de carácter motriz que restan a los cuerpos clasificados como femeninos la posibilidad de la igualdad. Como he señalado antes, uno de los mecanismos disciplinarios más recurrentes en la historia de la moda consiste precisamente en confinar el cuerpo de las mujeres a la inmovilidad. En esta medida, el estilo y la actitud feministas han reclamado para sí a lo largo de distintas épocas la posibilidad de un cuerpo capaz de moverse con mayor holgura. Si el estilo dandi pasa por una cierta reeducación de las propias maneras y por una pose hasta cierto punto afectada, el estilo feminista podría caracterizarse por un porte que busca la movilidad y la desenvoltura (de ahí la dificultad de pensar las insurrecciones de mujeres como ejercicios de estilo dandis: lo propio del estilo feminista pareciera antes la desenvoltura que la constricción del dandi). En tal sentido, varias de las revueltas vestimentarias por parte de las mujeres involucran la 
apropiación de dispositivos vestimentarios que las facultan para desplazarse y llevar a cabo acciones socialmente reservadas -disciplinamiento vestimentario de por mediopara el género masculino. En este sentido, los estilos feministas suelen buscar formas de dotar al propio organismo de prendas que posibiliten la igualdad con respecto a los cuerpos clasificados como masculinos. Se trata, tal y como lo conceptualicé en el capítulo anterior, de una in/corporación de la crítica, es decir, de una forma de trabajar el propio cuerpo para insuflarle un ethos contestatario en relación con lo instituido. Por tanto, los ejercicios críticos de estilo feministas constituyen, del mismo modo que los ejercicios críticos del dandi, formas de militancia corporal. En múltiples casos -y en los apartados siguientes mencionaré varios de ellos- las críticas feministas a los dispositivos vestimentarios que disciplinan el género no solo pasan, en efecto, por una teorización de porqué conviene que se amplíe el rango de movimiento para los cuerpos clasificados como femeninos, o de porqué es justo que dichos cuerpos puedan realizar actividades socialmente reservadas a los cuerpos clasificados como varoniles, sino que además consisten en una puesta en práctica de esas críticas. Así, el estilo feminista muestra cómo algunas constricciones consideradas naturales o intrínsecas al cuerpo femenino son en realidad el resultado de imposiciones innecesarias y violentas.

Estas características de la crítica feminista -a saber: la preocupación por generar desacatos estilísticos de carácter colectivo que ensanchen los parámetros de reconocibilidad, la recurrencia al escándalo como modo de visibilizar algunas problemáticas de las mujeres y la utilización de prendas que amplían el rango de movimiento como modo acceder a ciertos espacios reservados a los varones- comportan un estilo toda vez que involucran premisas éticas de autogestión corporal y modos de presentar el cuerpo para hacer irrumpir socialmente verdades alternativas a las hegemónicas. En esta medida, la pregunta para el feminismo en cuanto estilo es "de qué manera las formas o los artículos de vestir (...) pueden convertirse en sí mismos en sitios para la lucha política, cómo pueden ser usados de diversas maneras para impugnar el poder" (Parkins, 2010a, 2; traducción propia). 
En los apartados siguientes pretendo mostrar precisamente la manera en que ese desafío ha sido asumido por diferentes grupos de mujeres. Los casos elegidos, vale la pena señalarlo, solamente son indicativos. En otras palabras, muchos otros episodios de la historia de la moda y de la historia del feminismo podrían ser interpretados desde el punto de vista que acá propongo. Por ende, me limitaré a comentar aquellas expresiones que, además de estar documentadas, apelan a componentes estilísticos de manera más evidente. De este modo, mi interés es perfilar el estilo feminista como una forma de autogobierno corporal ejercido en el espacio público que impugna el disciplinamiento vestimentario, pero que hecha mano, en el mismo movimiento, de la prenda como un insumo útil para la crítica.

\subsubsection{De los esfuerzos reformistas a las mujeres deportistas: en busca de un estilo con movimiento}

Un primer conjunto de ejercicios críticos feministas surge de la conciencia del tratamiento diferenciado que socialmente se lleva a cabo mediante el vestido $-\mathrm{y}$ otros dispositivos más- de los cuerpos clasificados como femeninos en contraste con los cuerpos clasificados como masculinos, así como de las consecuencias que dicho tratamiento diferenciado producen en lo tocante a la libertad de movimiento. En su dimensión estilística estas revueltas reclaman la posibilidad para las mujeres de dotarse a sí mismas de una morfología y unas maneras más desenvueltas.

Es sabido que existen regímenes cinéticos diferenciales según los sexos desde la Antigüedad. Platón ilustra el asunto en La República, donde pese a que defiende la posibilidad y deseabilidad de que las mujeres lleven a cabo las mismas actividades que los varones, se habla de esa posibilidad como algo hasta cierto punto ridículo y risible según las convenciones de la época (República, 451c-457d). Esa misma sensibilidad que asocia el movimiento femenino con el ridículo se despliega a lo largo de la historia tomando diversas formas y articulándose con diferentes instituciones. Dentro de este contexto, el enemigo emblemático de las luchas estilizadas feministas ha sido el corsé. 
Como lo señalé en el tercer capítulo, en efecto, el corsé fue desde el Renacimiento e inclusive hasta el siglo XIX la principal prenda disciplinadora del cuerpo femenino. En oposición al corsé, por tanto, se articularon una serie de ejercicios de estilo mediante los cuales las mujeres rechazaron el uso, en nombre tanto de razones morales y de salud como de carácter estético - pluralidad de argumentos que habla, de nuevo, del carácter eminentemente estratégico de estas revueltas de estilo feminista-, de las prendas que las limitaban en sus movimientos. Esas críticas implicaban asumir, por contrapartida a las anatomías disciplinadas y docilizantes difundidas por las modas, una morfología y unas prendas alternativas. Los ejercicios estilísticos seguidos de esas críticas, los cuales en realidad tuvieron lugar a lo largo de toda la historia del corsé, probablemente encontraron en los movimientos reformistas del traje de mitades del siglo XIX su expresión más acabada.

Dichos movimientos recogen, en efecto, la lucha histórica de las mujeres por dotarse a sí mismas de un cuerpo alternativo al cuerpo constreñido impuesto por las prácticas disciplinarias. Así, tal y como lo indica Elizabeth Wilson, los grupos feministas que proponían reformas en la vestimenta estaban asociados, desde sus inicios, con políticas progresistas que poseían una visión politizada del cuerpo (Wilson, 2003, 208). Varios historiadores e historiadoras del vestido -en cuenta por ejemplo Laver ([1982] 2008, 182), Wilson (2003, 208-227) y Bard ([2010] 2012, 98-105)- coinciden en lo tocante al hecho de que la más importante agrupación reformista surgió en Estados Unidos en 1851 con Amelia Bloomer a la cabeza. Heredando una serie de impugnaciones críticas que habían realizado mujeres en relación con el atuendo al menos desde el siglo XVIII, Bloomer desata, en efecto, una reacción en cadena a partir de su intento de

inducir a las mujeres a adoptar su traje sensato [pero] no por ello menos femenino. Se trataba de una versión simplificada del corpiño de moda y una falda bastante ancha que llegaba por debajo de la rodilla, aunque, debajo de ésta, se podían ver unos pantalones holgados que llegaban hasta el final de los tobillos (Laver, [1982] 2008, 182)

Es este último elemento, el pantalón, lo que resulta más escandaloso para la mentalidad del siglo XIX. La recurrencia a ese elemento indumentario, en efecto, significaba 
habilitar al cuerpo femenino para que realizara una serie de acciones que históricamente le habían sido vedadas a las mujeres. La politización del pantalón por parte del feminismo del siglo XIX -pues efectivamente se trata de una politización crítica de esa prenda lo que está en juego, dado que como lo señala Bard "no hay nada liberador en sí mismo en el pantalón" ([2010] 2012, 96)- constituye un ejercicio de estilo con todas las de ley. El estilo feminista, de hecho, recurre al pantalón a la manera de un insumo técnico para la resignificación de "lo" femenino. Detrás de la apropiación del pantalón por parte de las mujeres existe, en efecto, toda una politización de la vestimenta y de la generización políticamente interesada que ella induce. Bloomer y sus compañeras reclaman ciertamente el derecho al pantalón como parte de una reivindicación más amplia que incluía el derecho a renegar de la anatomía constreñida que las prendas de la época buscaban imponer. El contraataque de parte de los discursos higienistas y normalizadores, como lo señala Christine Bard, repara en ello: se alega que el pantalón implica un ataque al caballero victoriano y un intento de usurpación de prendas por definición masculinas. De hecho, la reacción es tan virulenta que entre 1852 y 1856 el feminismo hace una pausa en relación con la cuestión del traje. No obstante en 1856 se retoma el tema y ya para finales del siglo XIX las mujeres de ciertas clases sociales y en ciertas zonas del mundo occidental comienzan a utilizar el pantalón sistemáticamente. ${ }^{51}$

La adopción permanente del pantalón significó el abandono definitivo del corsé. En el marco de los combates reformistas las mujeres alegaron razones de toda índole: religiosas, prácticas, estéticas, biológicas y médicas. Todos esos alegatos, sin embargo, coincidían en reivindicar el derecho a establecer una relación con el propio cuerpo distinta a la impuesta por las costumbres vestimentarias al uso. Lo que estaba en juego no era sino la disputa en torno al criterio de racionalidad al cual debía atender el cuerpo, y con ello, el tipo de aptitudes físico - morales que le correspondían a este.

Por otra parte, cabe recordar que el rechazo del corsé y la adopción del pantalón se consiguen mediante acciones corporales de conjunto. ${ }^{52} \mathrm{~A}$ menudo, durante la segunda

\footnotetext{
${ }^{51}$ Estos últimos datos históricos se encuentran consignados en Bard ([2010] 2012, 98-105).

${ }^{52}$ Ampliaré lo referido a la cuestión de la apropiación del espacio público por parte de los colectivos de mujeres en el próximo apartado.
} 
mitad del siglo XIX grupos de mujeres se presentan en público desacatando el mandato vestimentario de no usar pantalón y por ello son blanco de ataques por parte de varones escandalizados y preocupados por conservar sus privilegios. Esta politización del vestido despliega, por cierto, una estrategia estilística muy propia del feminismo. Contrariamente al dandismo, en el cual la difusión masiva de una tendencia vestimentaria era percibida como un atentado contra la originalidad, el estilo feminista no es renuente a la difusión masiva de sus atuendos críticos. De hecho, la reivindicación de una anatomía femenina más desenvuelta y autónoma es objeto de una politización inclusive a través de las revistas de moda. ${ }^{53}$ En la medida en que el feminismo lucha por la consecución de libertades y no por una reafirmación de la propia singularidad, el hecho de que una práctica vestimentaria liberadora sea acogida masivamente no es sinónimo de fracaso como lo sería para el dandi. Por el contrario, el estilo feminista se aprovecha de los mecanismos de difusión masivos para ensanchar los parámetros a partir de los cuales las épocas definen los arquetipos de feminidad. En tal sentido, el estilo feminista, al menos en su versión reformista, no necesariamente siente animadversión hacia la popularización de una determinada prenda; por el contrario, dado que dicho estilo busca desatar rebeldías en el marco de un continuum histórico y acumular fuerza para una causa política, el hecho de que se consiga extender el uso de una prenda mediante la difusión de una tendencia vestimentaria se interpreta como una conquista parcial dentro de un conjunto de batallas por librar en aras de ganar una autonomía cada vez mayor. Dentro de la sensibilidad política del estilo feminista, de hecho, ninguna batalla se considera del todo concluida. Desde este punto de vista, la opinión de Benjamin según la cual algunas libertades vestimentarias conseguidas por las mujeres en el siglo XIX se dan automáticamente por efecto de una necesidad del capitalismo de integrar a las mujeres como parte de la fuerza de trabajo -véase Benjamin ([1974] 2012,171-172)- resulta reductiva e implica, además, una invisibilización del efecto que tuvieron las luchas de ciertos colectivos feministas. Que esas conquistas hayan sido integradas dentro de un marco capitalista no debe interpretarse, en mi opinión, como señal de su fracaso, sino de

\footnotetext{
${ }^{53}$ En la Argentina del siglo XIX, por ejemplo, las revistas de moda inclusive llegaron a servir como plataforma para la reivindicación de la igualdad y para la crítica a la idealización del cuerpo femenino propio de la moda en período de Juan Manuel Rosas. Véase al respecto Root (2002).
} 
que las mismas constituyeron avances parciales, en razón de lo cual es necesario continuar abriendo nuevos espacios para la libertad corporal de las mujeres.

De hecho, el estilo feminista retoma durante el siglo $\mathrm{XX}$, aunque en un campo enteramente diferente, las luchas reformistas del siglo XIX. Me refiero al campo del deporte. ${ }^{54}$ Allí, de nuevo, se trata de una revuelta vestimentaria con rasgos de estilo. Pese a que el acceso de las mujeres al mundo del deporte suele presentarse únicamente como la consecución de un derecho, en realidad, dicha consecución es fruto de una batalla cultural estilística -sobre todo si se toma en cuenta que el primer boom de este tipo de indumentaria se da a finales del siglo XIX con deportes practicados al aire libre como el ciclismo, lo cual involucraba la presentación pública de un cuerpo femenino ataviado de forma escandalosa (Laver, [1969] 1982, 210)-. Para la historiadora feminista Christine Bard, en este sentido, "las prendas deportivas son las aliadas objetivas del movimiento de emancipación de las mujeres" (Bard, [2010] 2012, 161). La propia Bard ofrece ejemplos de mujeres que, como Violette Morris, accedieron al mundo del deporte durante el siglo XIX desplegando un estilo corporal que suscitó el escándalo de sus contemporáneos (Bard, [2010] 2012, 205-228).

Lo que la prenda deportiva, en tanto dispositivo estilístico de género proporciona al feminismo en ese tránsito entre siglos es, pues, la posibilidad de modificar profundamente la trama conformada por lo que en el capítulo cuarto denominé los dispositivos interaccional, ceremonial y espacial. En otras palabras, la prenda, en tanto insumo técnico, posibilita un cuestionamiento feminista del control biopolítico sobre los cuerpos clasificados como femeninos - de hecho, en el texto platónico antes referido, el acceso de las mujeres a la gimnasia se considera un hecho político de la misma relevancia que el acceso a la educación o las artes: para Platón el aumento de las aptitudes físicas redunda, en efecto, en la consolidación de un cierto estatuto político (República, 451c457d)-.

\footnotetext{
${ }^{54}$ Sobre la revolución inducida a partir de la introducción de la indumentaria deportiva en la vida cotidiana, consúltese Yonnet ([1985] 2005, 256-263).
} 
Un nuevo estilo de encarnar la feminidad y de desplegarla en el ámbito urbano se abre entonces paso a partir de estos ejercicios críticos; en él, la agilidad y la destreza, el dinamismo y la resolución a la hora de moverse se enfrentan a la anatomía femenina sometida por las disciplinas. Se trata de una disputa pública en la que el disciplinamiento vestimentario, el cual confina a las mujeres a la inmovilidad, encuentra su cuestionamiento crítico en el propio cuerpo de las mujeres emancipadas. Hay en juego, pues, dos regímenes de gestión corporal: de un lado, una biopolítica patriarcal que busca perpetuar el confinamiento del cuerpo femenino a la inmovilidad, y de otro, un ethos rebelde que reclama movilidad para las mujeres y que despliega esa rebeldía en espacios públicos.

Desde los proyectos reformistas del vestido a la apropiación feminista de la indumentaria deportiva hay, por tanto, todo un espectro de batallas estilísticas. Los estilos feministas se revelan en tal sentido como tipos de gestualidades que rechazan los modos gráciles supuestamente intrínsecos a la feminidad para reivindicar, desde el propio cuerpo, una feminidad alternativa. Pese a lo variopinto de los argumentos esgrimidos por parte de las mujeres que desplegaron estos ejercicios críticos de estilo, persiste, en efecto, un núcleo duro de cuestionamiento a la naturalización de ciertos roles y al control biopolítico de los cuerpos femeninos. En tal sentido, los esfuerzos feministas por sacudir los cuerpos de las gramáticas que se les suponen intrínsecas incluían una ética en el sentido foucaultiano de esa categoría; las mujeres que se rebelaban contra dichas gramáticas lo hacían, en efecto, desde sus propios cuerpos, a través de un trabajo continuado que proporcionaba formas críticas a los mismos.

\subsubsection{Las luchas feministas por el reconocimiento y el estilo como elemento de protesta: el ejemplo sufragista}

Un segundo conjunto de ejercicios críticos feministas ha estado dirigido a cuestionar los parámetros ontológicos a partir de los cuales se regula el acceso diferenciado según el género a ciertas instituciones y derechos. Estas luchas feministas ciertamente poseen una 
dimensión propiamente jurídica, pero es igualmente cierto que las mismas han contenido un repertorio de acciones corporales estilizadas que bien vale la pena analizar en el contexto de esta investigación, sobre todo tomando en cuenta que en ellas la vestimenta ha tenido un rol importante aunque hasta cierto punto desatendido por los teóricos de la moda.

En su versión moderna dichos ejercicios críticos tienen la pretensión de garantizar el acceso de las mujeres a ciertos ámbitos - como la ciudadanía o el trabajo remunerado- de los cuales han sido históricamente marginadas. Pero en última instancia, y vistos dentro una perspectiva histórica amplia, estos ejercicios poseen el objetivo más abarcador de cuestionar los conceptos a partir de los cuales se generan procedimientos de exclusión y violencia -no solo discursivos, sino también materiales- en contra de los cuerpos clasificados como femeninos. De ahí la importancia que en estos ejercicios estilísticos ocupa el vestido: se trata de postular el propio cuerpo como soporte del reconocimiento, al tiempo que se presentan públicamente tipos de subjetividad que comprometen a la ontología social dominante a reconocer sus exclusiones.

Las luchas sufragistas constituyen un hito histórico susceptible de ser analizado dentro de este segundo conjunto de gestualidades estilísticas feministas que intento caracterizar. En ellas, en efecto, la utilización crítica del vestido se inscribe dentro de una larga tradición de un uso estilizante de las prendas como método de visibilización de reivindicaciones políticas. Los sans-culotte de la Francia revolucionaria, por ejemplo, ya habían utilizado la indumentaria como medio de identificación colectivo y como elemento de contraste en relación con la élite burguesa a la cual se oponían. La expresión sans-culotte, como se sabe, significa literalmente "sin calzones" y se utilizaba inicialmente para designar a las clases francesas más desposeídas de finales del siglo XVIII, haciendo alusión al hecho de que las mismas carecían de los medios para hacerse con prendas tales como los calzones, de las cuales dependía la respetabilidad y honorabilidad sociales (Wrigley, 2002). Tal y como lo señala el historiador del arte Richard Wrigley, sin embargo, tal expresión es objeto de una resignificación por parte de las clases populares: la noción sans-culotte pasa de ser un insulto dirigido a aquellos con aspecto andrajoso y desaliñado a ser un 
lugar para la identificación colectiva -"sin calzones", de hecho, comienza a significar paulatinamente sin los calzones de la aristocracia, es decir, pasa a referirse a aquellos cuyo estilo corporal difiere del de los poderosos (Wrigley, 2000)-. Se trata de un procedimiento similar al descrito por Judith Butler en su obra Lenguaje, poder $e$ identidad ([1997] 2004) cuyo objetivo es convertir la ofensa en un lugar para la agencia. No obstante, para los sans-culottes no se trataba de una cuestión únicamente semántica. Tal concepto, de hecho, al pasar a designar a sectores sociales cada vez más amplios agrupados bajo los ideales de la Revolución, comienza a exigir de quienes deseaban ser cobijados por tal categoría la puesta en marcha de un cierto trabajo con el propio cuerpo y el atuendo. Identificarse como sans-culotte implicaba, pues, un compromiso con un cierto estilo corporal así como la adopción de unas determinadas prendas -específicamente pantalones, "carmañolas" (es decir, un tipo especial de chaqueta corta) y gorros de lana de color rojos (Bard, [2010] 2012, 30)-. ${ }^{55}$

Pero mientras que tal modo de vestir se convertía en el estilo revolucionario por definición, dicho estilo era vedado a las mujeres. En efecto, "cuando la más radical de las agrupaciones políticas de mujeres, la Sociedad de Republicanas Revolucionarias, trata de imponer el uso del gorro rojo [entre sus militantes,] son ridiculizadas en sus esfuerzos" (Parkins, 2002a, 6; traducción propia). La Revolución termina con las leyes suntuarias pero establece un nuevo procedimiento de exclusión vestimentaria. A partir del triunfo de la Revolución, de hecho, se busca imponer un nuevo atuendo patriótico exclusivo de los cuerpos clasificados como masculinos, con lo cual, lo que había empezado como un estilo indumentario popular, acaba en un régimen vestimentario con tintes disciplinarios. Dentro de ese nuevo orden, los cuerpos masculinos gozarán de una mayor legitimidad:

[...] en el nuevo cuerpo social, con la nación redefinida, los hombres obtienen el reconocimiento del derecho natural a la vestimenta. El cuerpo masculino está cargado, pues, de un significado político bastante prodigioso (...). El cuerpo femenino y el infantil, menos determinados, son portadores de otro imaginario más discretamente político, el de la inocencia, de la virtud, simbolizada por el blanco (Bard, [2010] 2012, 33-34).

\footnotetext{
${ }^{55}$ Otro tanto ocurrió en Argentina en el caso de los descamisados del primer peronismo, los cuales generaban identificación colectiva mediante el descubrimiento del torso.
} 
Tras este episodio histórico, el estilo feminista radicaliza este tipo de utilización crítica de la indumentaria utilizada durante la Revolución. Mientras que en el caso de los sansculottes la prenda se empleaba como recurso crítico en la medida en que involucraba una actitud transformadora y resignificante, así como la posibilidad de producir subjetividades colectivas, el estilo feminista añadirá un elemento más: la premisa de que además de esas funciones las prendas podrían ser útiles como instrumentos a la hora de buscar una inclusividad política radical.

De ahí que los movimientos sufragistas utilizaran la prenda como insumo crítico a la hora de cuestionar las nociones de ciudadanía y universalidad. Es dicha noción, de hecho, la que se sitúa en el centro de las polémicas sufragistas. Toda vez que, como lo señalan las teóricas australianas Moira Gatens y Alison Mackinnon, "el concepto de ciudadanía y de ciudadano es inestable e históricamente contingente" $(1998,7)$, pero también, cabe agregar, un concepto que provee el acceso a instituciones y derechos, las sufragistas desarrollan un estilo corporal en el que se despliegan múltiples estrategias en busca de la consecución del estatus de ciudadanas. Así, por ejemplo, las sufragistas llevan a cabo ejercicios de estilo como la adscripción política a través de los elementos cromáticos de sus atuendos, la incorporación de elementos vestimentarios para generar escándalo y el cuestionamiento del propio sentido de "lo" femenino. La militante sufragista, en efecto, se caracteriza por la utilización de ciertos colores -en el caso británico, por ejemplo, el verde, el púrpura y el blanco (Parkins, 2002a)-, pero antes que de una adscripción pasiva a una norma vestimentaria, para las sufragistas de lo que se trataba mediante su adhesión a esos recursos cromáticos era de emerger como actoras políticas y de cuestionar, así, los parámetros de legibilidad de lo femenino a partir de los cuales eran percibidas.

Wendy Parkins señala al respecto cómo esa aparición de grupos numerosos de mujeres en al ámbito público ataviadas de manera similar producía un escenario hasta cierto punto espectacular: 
[...] la experiencia (...) de los espectáculos sufragistas -miles de mujeres marchando en formación alrededor de las calles de Londres- no solo dotó lo público de un nuevo sentido (incluyendo a las mujeres como sujetos políticos) ni se limitó a articular un nuevo tipo de demanda (por la emancipación), sino que también construyó a la sujeto sufragista como una agente política encarnada (Parkins, 2002b, 102; traducción propia).

Se trata, por tanto, dentro del estilo feminista, de llevar a cabo un tipo de ejercicio en el que, mediante el atuendo, se despliegue un ethos colectivo rebelde que desafíe las convenciones jurídicas y sociales de época que disciplinan el cuerpo de las mujeres.

En esta gestualidad, por cierto, se da un doble movimiento que implica desmarcarse de una identidad previamente asignada - la de la feminidad entendida de forma pasiva y dócil- y de identificarse con un nuevo tipo de subjetividad emergente que se produce mediante las actuaciones rebeldes en el espacio público. Parkins señala al respecto cómo en el caso británico "a través del uso de la moda y de colores específicos, las sufragistas se forjan una identidad colectiva en espacios públicos de la ciudad y se introducen a sí mismas y su causa dentro de la esfera de la comunicación política" (Parkins, 2002b, 99). Tomando en cuenta, pues, que la comunidad política no es algo dado, la gestualidad corporal de las sufragistas involucraba un reclamo respecto de su exclusión de dicho ámbito. La militancia sufragista pasaba, pues, por asumir un estilo corporal crítico de reclamo en contra de la desigualdad. El vestido se conceptualiza políticamente como un mecanismo pertinente -entre otros- para cuestionar la manera en que lo común se sostiene sobre la base de ciertas exclusiones constitutivas. En tal sentido, para las sufragistas "el vestido no era una distracción trivial de su campaña sino que por el contrario constituía una expresión del compromiso con la causa y una parte integral de su identificación y su actuación [performance] como sufragistas" (Parkins, 2002b, 102; traducción propia).

Wendy Parkins hace inventario de los múltiples accesorios utilizados por las sufragistas a manera de insumos técnicos: joyería, insignias, botones, lazos, bufandas y pañuelos (Parkins, 2002b, 102). El estilo feminista del movimiento sufragista incluso echa mano de algunos de esos elementos a la manera de un disfraz -sobre las apropiaciones 
feministas de los disfraces y las máscaras como herramientas críticas véase Tseëlon (2001)-. Al respecto, Parkins señala cómo ciertos atuendos permitían a las militantes sufragistas evadir la policía (cambiándose el aspecto en pleno acto de protesta para no lucir acorde con las descripciones a partir de las cuales eran buscadas), llevar a cabo actos subversivos como el lanzamiento de piedras (usando cierto tipo de sombreros cuyas anchas alas las descartaban como sospechosas debido a que se presumía que una mujer elegante no podía ser culpable de lanzar piedras) o bien atraer o desviar la atención durante las manifestaciones según resultara conveniente (Parkins, 2002b, 107-121). Ese conocimiento de los códigos vestimentarios y la capacidad correspondiente de poner en marcha una utilización estratégica de los mismos da cuenta del uso eminentemente politizante de las prendas de parte de las militantes sufragistas. Lejos de una simple función ornamental, pues, las sufragistas dotaban a sus prendas de un estatuto emancipador que potenciaba sus reivindicaciones colectivas.

Utilizaciones semejantes de las prendas han tenido lugar en diversas ocasiones, asimismo, a lo largo del siglo XX. El uso político que las sufragistas han llevado a cabo de ciertas prendas, de hecho, constituye solamente uno entre múltiples casos analizables de este tipo de gestualidad crítica destinada a reclamar públicamente reconocimiento (aunque dentro de una perspectiva histórica ciertamente se trata de un caso importante por las repercusiones que tuvo). El caso argentino de las Madres y Abuelas de la Plaza de Mayo y su utilización del pañuelo blanco como recurso para la identificación colectiva y como elemento material de empoderamiento en la escena pública, por ejemplo, podría ser analizado igualmente como un caso de agenciamiento que echa mano de las prendas como recursos para la crítica. Del mismo modo, las quemas públicas de sostenes como modo de protesta en contra del sexismo podrían interpretarse en esta línea. ${ }^{56}$

Más allá de los ejemplos, sin embargo, lo que me interesa destacar acá es cómo dentro del uso políticamente estratégico que los movimientos de mujeres han hecho del dispositivo vestimentario se perfila una modalidad crítica en la que la prenda constituye

\footnotetext{
${ }^{56}$ Sobre el tema de la quema de sostenes y la manipulación mediática de la que ha sido objeto dicha práctica véase Wilson $(2003,230)$.
} 
un elemento gestor de identidad colectiva y un mecanismo para irrumpir en la escena pública exigiendo reconocimiento a través del estilo. Las prendas aparecen, en este sentido, no ya como dispositivos disciplinantes sino como mecanismos que permiten la identificación momentánea y la articulación de reivindicaciones situadas usualmente relacionadas con el reconocimiento y la consecución de derechos. Así, no obstante la pluralidad de manifestaciones históricas de este tipo de gestualidad crítica feminista, lo cierto es que las mismas ponen en marcha un tipo de ejercicio estilístico en el que la crítica, de nuevo, dota al cuerpo de una morfología alternativa.

\subsubsection{El rechazo de las técnicas de embellecimiento como ejercicio de estilo}

Un último tipo de ejercicio crítico de estilo feminista se relaciona con el rechazo de los ideales de belleza y con el repudio del disciplinamiento del cuerpo femenino que se realiza a partir de los mismos. Se trata de una serie de mecanismos estilísticos de resistencia mediante los cuales se vuelve posible trabajar el propio cuerpo de una manera alternativa a la propuesta por la moda. El acicalamiento, en tal sentido, se convierte en un recurso técnico mediante el cual el trabajo de las mujeres sobre sus propios cuerpos deviene elemento crítico de unas normas que, por contrapartida, buscan disciplinar esos mismos cuerpos a la medida del deseo masculino. En esta faceta, el estilo feminista se torna mecanismo de desidentificación -es decir, instancia de desafiliación respecto de las características supuestamente constitutivas del aspecto femenino- convirtiendo el atuendo y el cuerpo en fuentes críticas de los procesos normalizadores.

El rechazo de las técnicas de embellecimiento y la renuencia a construir el propio cuerpo como objeto de contemplación para la mirada masculina constituyen, de hecho, pautas críticas que han alimentado históricamente el estilo feminista. En Tres guineas, la ya mencionada obra de Virginia Woolf, la autora reflexiona en torno a este asunto. Woolf caracteriza la oposición femenina al atavío excesivo como una forma de crítica a los mandatos masculinos y plantea la sobriedad en el atuendo como una estrategia para objetar lo que en el capítulo tres de esta investigación he denominado dispositivo 
ceremonial (a saber, el conjunto de prescripciones mediante las cuales se determina el modo en que los cuerpos deben actuar socialmente a partir del atuendo que llevan). Así, según Woolf, mientras que algunos de sus contemporáneos varones consideraban que el atavío femenino debía ser fastuoso como una forma de compensar una supuesta inferioridad biológica de las mujeres, lo cierto es que eran los propios varones de la época los que hacían gala de los más ostentosos, y a juicio de Woolf ridículos, atuendos.

En efecto, para la autora, las mujeres establecen una especie de resistencia corporal en relación con esos mandatos que dictan un excesivo arreglo en el vestir (Woolf, [1938] 1999, 37). Si el vestido lujoso es planteado por la sensibilidad de su época como una forma accesible para las mujeres de compensar supuestas inferioridades y, en suma, como la forma adecuada de "ser" mujer, Woolf destaca, por su parte, la posibilidad para las mujeres de recurrir a la austeridad vestimentaria como un modo de desatender esos mandatos. El estilo austero planteado por Woolf prescinde de las prendas lujosas no debido a una aversión al adorno en cuanto tal, sino precisamente a que dichas prendas establecen estereotipos sociales y limitan las posibilidades corporales de las mujeres (Woolf, [1939] 1999, 200).

El desacato feminista del lujo descrito por Woolf constituye un ejercicio de estilo pues no se agota en la preferencia de un modo de vestir por sobre otro, sino que implica una politización crítica de la propia forma de vestir como un modo de develar las implicaciones disciplinarias involucradas en una adecuación irreflexiva a las normas vestimentarias al uso. ${ }^{57}$ La austeridad vestimentaria enarbolada por Woolf aparece como una forma de resistencia a los roles sociales que la moda intenta imponer a las mujeres. Se trata acá, al igual que en el dandismo, de realizar una suerte de ascesis politizada mediante la cual el propio cuerpo se trabaja a partir de un principio ético crítico para rebelarse, en este caso, en contra de la norma que determina qué es un cuerpo bello. La austeridad aparece entonces dentro de este contexto como una posibilidad estratégica, es decir, como una opción para el despliegue del éthos crítico feminista.

\footnotetext{
${ }^{57}$ La filósofa y politóloga uruguaya Laura Gioscia lee en una clave similar la renuencia de algunas mujeres actuales a someterse a los ideales de delgadez impulsados por la moda; véase Gioscia (2008, 85-86).
} 
Es posible decir otro tanto con respecto a ciertas tendencias vestimentarias asumidas de forma masiva por las mujeres durante el siglo XX. Los diseños de Coco Channel, por ejemplo, revolucionaron el mundo de la Alta Costura con una serie de trajes cuya simpleza -contrastante con el gusto masculino de la época "por el adorno, la elegancia del diseño y el mimo en la elección de sombreros" (Gavarrón, 1982 216) - recuerda a ese llamado woolfiano a la sobriedad. Channel, en efecto, disputa a su época el contenido de la noción de belleza femenina oponiendo con sus diseños "las prendas de punto, [los] trajes de sastre y vestidos, y [las] chaquetas y marineras que evoca[ba]n (...) simplicidad, [al] exceso de feminidad -es decir, a la exageración en la ornamentación y la sexualización en el vestir-" (Bard, [2010] 2012, 232). De nuevo, la propagación masiva de una tendencia vestimentaria aparece acá no rivalizando con el estilo, sino como un mecanismo difusor del mismo. El trabajo de Channel, de hecho, es el resultado, en el mundo de la Alta Costura, de toda una serie de intentos feministas por revertir los efectos del disciplinamiento vestimentario y por resignificar las nociones de feminidad y belleza así como la relación entre ambas.

El rechazo de los ideales involucrados en las técnicas de embellecimiento supone además, como lo señalé antes, la renuencia a asumir una anatomía diseñada en la medida del goce de la mirada masculina. La moda, como indiqué en los capítulos 3 y 4, establece, de hecho, un tipo de dinámica social en el que una serie de movimientos y rituales sociales están en función de un régimen de control heterocéntrico de la sexualidad. Las teorías sobre la moda legitiman, por cierto, dicha dinámica. Para Simmel, por ejemplo,

[...] la historia de las mujeres muestra que su vida exterior e interior, individual y colectivamente, ofrece tal monotonía, nivelación y homogeneidad, que necesitan entregarse más vivamente a la moda, donde todo es cambio y mutación, para añadir a su vida algún atractivo. Y esto no solo para encontrar ellas mejor sabor a la existencia, sino también para que los demás las encuentren a ellas más sabrosas $(2008,86)$.

Rechazar los ideales normalizadores de belleza involucra, por tanto, desarticular este grotesco imaginario patriarcal a partir del cual los cuerpos femeninos se alienan en 
función de su ofrecimiento a la mirada masculina y de la regulación de sus interacciones sociales. Este ejercicio crítico propio del estilo feminista, consistente en desacatar voluntaria y sistemáticamente los ideales de belleza, vuelve, de hecho, la mirada masculina en contra de sí misma: la deconstrucción en y con el propio cuerpo de los estereotipos de belleza desnuda los roles sociales que se sostienen performativamente a partir de su repetición social. Al desatender la prerrogativa de acicalarse en función de la mirada masculina, el estilo feminista evidencia el carácter contingente de esa mirada y le devuelve una imagen distorsionada de las esencias de género.

Así, rechazar -o bien tergiversar, parodiar, o exagerar- las técnicas dirigidas a embellecer el cuerpo supone también rechazar el control social y erótico que se sigue a partir de ellas. El estilo feminista evidencia que el atavío no tiene porqué consistir para las mujeres en una técnica de embellecimiento del propio cuerpo para su exposición a la mirada masculina; esa, de hecho, es solo una de las posibles relaciones entre vestimenta, género y deseo. En esta medida, el estilo feminista involucra la legitimación de diversas vías para el deseo y el cuestionamiento del paradigma heterocéntrico en tanto eje normalizador del deseo. El estilo feminista cuestiona, en esta media, el deseo heterocéntrico como modelo único. La crítica feminista abre así la posibilidad de una gestión del propio cuerpo no destinado a la otredad, y en esa medida, evita el cierre de la categoría "mujer".

La sobriedad propuesta por Woolf o la simplicidad defendida por Channel, sin embargo, son solo manifestaciones históricas de una actitud crítica que perfectamente puede elegir el camino del escándalo: de lo que se trata, finalmente, no es de la sobriedad en cuanto tal, sino de deconstruir el modo en que los ideales sobre la belleza femenina crean un cuerpo dócil dispuesto pasivamente para su contemplación. En pocas palabras, si la coquetería y el maquillaje, tal y como los pensaba Simmel, tienen como objeto construir un cuerpo femenino para ser mirado -véase especialmente su Filosofía de la coquetería ([1909] 2008)-, la gestión de un cuerpo que rechaza ataviarse según dictan las normas estéticas de una determinada época involucra un cuestionamiento del núcleo mismo que define, en una determinada época, en qué consiste la feminidad. 
En síntesis, considero que dentro de los ejercicios críticos del estilo feminista figuran los desacatos de los ideales de belleza, en la medida en que dichos desacatos pretenden cuestionar, a través del trabajo ético con el propio cuerpo, el sentido mismo de "lo" femenino. En tanto ejercicio crítico de estilo, pues, este rechazo de los ideales de belleza no se agota en una mera desavenencia con una forma de vestir; por el contrario, es la propia crítica al ideal de belleza lo que in/forma el cuerpo estilizado feminista.

Al igual que en el caso del dandismo, sin embargo, cabe señalar que estilo feminista se ocupa de deconstruir críticamente uno solo de los dos polos del binarismo de género: el polo femenino. En efecto, y debido a la naturaleza del movimiento feminista, las interrogaciones críticas dentro de este estilo se dirigen fundamentalmente a la deconstrucción del disciplinamiento de género dirigido a los cuerpos clasificados como femeninos. Si bien es cierto el estilo feminista tiene un horizonte crítico que permea la organización social como un todo y que alcanza a cuestionar indirectamente el disciplinamiento vestimentario también en relación con los cuerpos clasificados como masculinos, parece claro que el feminismo precisa de la noción "mujeres", al menos como base para la construcción de agenciamientos colectivos. Si bien dicha categoría, como he intentado mostrar, opera en el estilo feminista como una suerte de instancia conceptual para las luchas sociales y no necesariamente como una esencia estable, lo cierto es que las estrategias estilísticas del feminismo tienen un flanco de lucha definido (y es de hecho deseable que así sea) en el disciplinamiento vestimentario dirigido en contra de los cuerpos femeninos.

Esto no necesariamente constituye una limitación, sino más bien una elección estratégica. De ahí, justamente, que otra posible veta crítica podría estar dirigida a cuestionar el propio núcleo binarista de los géneros que motoriza el disciplinamiento vestimentario. En el próximo capítulo me dedicaré a analizar la androginia como una deriva estilística capaz de acometer precisamente tal cuestionamiento. 


\section{Capítulo 7. Brotes estilísticos andróginos: a propósito de la posibilidad de un estilo allende el género}

En las páginas anteriores he pretendido mostrar que el género constituye un enclave central dentro del conjunto de mecanismos de poder que intentan disciplinar el cuerpo mediante el vestido. Según lo he planteado anteriormente, a partir de una relación performativa con la diferencia sexual, la moda echa a andar una serie de estrategias a través de las cuales la vestimenta se erige como un mecanismo de gobierno de los cuerpos, las subjetividades y la vida colectiva. En suma, la moda, tal y como la he comprendido a lo largo de este trabajo, tiene en la dicotomía sexual un núcleo estructurante. Inclusive los estilos analizados en el capítulo anterior, aún cuando procuran horadar la antropología filosófica subyacente al binarismo sexual, tienden a ser críticos ora de los dispositivos de masculinización, ora de los mecanismos de feminización, pero no de la propia matriz a partir de la cual se engendra la división entre lo femenino y lo masculino. En otras palabras, al no enfilar sus protestas contra el núcleo dicotómico en sí, estos estilos mantienen cierto binarismo sexual en la base de sus críticas -cierto que con grados y matices según sea la expresión estilística de la que se trate-. Ello, como ya he señalado antes, no necesariamente constituye una insuficiencia, en la medida en que las gestualidades estilísticas no se ven disminuidas por la heterogeneidad: por el contrario, la multiplicidad de opciones emancipatorias robustece las posibilidades de la crítica. Por otro lado, debilitar alguno de los opuestos de una polaridad ontológica implica en cierto modo un debilitamiento de la polaridad en sí.

En todo caso, dichos estilos, al evidenciar a través de la vestimenta el carácter contingente de la masculinidad y la feminidad abren el camino para formular interrogantes adicionales relacionadas con las posibilidades y alcances de la crítica estilística. En efecto, a partir de las críticas dandista y feminista se vuelve viable la pregunta de si un estilo podría apuntar a desestabilizar la propia matriz dicotómica de género. En otras palabras, los estilos anteriormente estudiados posicionan la pregunta de 
si algún ejercicio crítico podría eventualmente apuntar contra el binarismo sexual mismo. Responder dicha pregunta no equivale a arribar a un punto en el que la moda desaparezca como mecanismo de dominación, pues como señaló en reiteradas ocasiones Foucault, no existe un grado cero del poder en el que este cese por completo. ${ }^{58}$ Por el contrario, abordar esas interrogantes supone pensar los límites de la moda tal y como se ha desplegado históricamente en Occidente. En otras palabras, analizar estas cuestiones implica colocarse en un umbral en el que la moda, en tanto dispositivo de poder, se ve interrogada en sus rasgos constitutivos.

La posibilidad de trascender el binarismo sexual ha sido objeto de preocupación tanto en un nivel práctico como en el plano discursivo. En otras palabras, la posibilidad de superar la polaridad masculino/femenino, en el sentido de volver tal dicotomía ontológicamente irrelevante, ha conocido tanto versiones históricas (a través de un conjunto de expresiones que enfatizan la combinatoria de elementos de ambos sexos) como versiones teoréticas basadas en la naturaleza metafísica de tal dicotomía (me refiero no solo a discursos filosóficos que se ocupan de dicha cuestión sino también a relatos míticos que abordan la temática). En este capítulo mi intención es conceptualizar de qué manera esas múltiples expresiones han desembocado (pero también podrían llegar a desembocar) en una androginia entendida como enclave vestimentario de la crítica. Por ende, me interesa mostrar hasta qué punto la androginia podría desbordar el registro de lo propiamente mítico para ser analizado en términos de estilo.

A diferencia del análisis que realicé alrededor de los ejercicios estilísticos del capítulo anterior, en este caso pretendo, por tanto, analizar una tentativa estilística -la androginiaaún no desarrollada en toda su potencialidad. Para ello describiré, en primera instancia, la androginia mítica, es decir, la irrupción de la figura del andrógino dentro de un contexto alegórico (paradigmáticamente expuesto en el Banquete platónico) que no obstante se vincula metafóricamente con los cuerpos y la sexualidad. En el segundo apartado, discutiré la recepción freudiana de la androginia platónica, y el modo en que el psicólogo

\footnotetext{
${ }^{58}$ Ese carácter irreductible del poder, específicamente en relación con la vida corporal, es puesto de relieve en la entrevista Poder-Cuerpo (Foucault, [1975] 1992, 112-113).
} 
vienés utiliza la figura del andrógino dentro de su teoría de los instintos para intentar explicar el funcionamiento del deseo sexual. Dado, sin embargo, que dicha recepción freudiana -no obstante que ofrece la posibilidad de pensar en una androginia más vinculada a los cuerpos "reales" y a la historia- restringe al andrógino al ámbito anatómico/genital, procederé, en el tercer apartado, a mostrar la presencia de la androginia en la historia de la cultura allende lo planteado por Freud. En función de ello, realizaré algunas precisiones conceptuales referidas a las diferencias entre el andrógino y otras figuras limítrofes como la de el/la travesti y el hermafrodita, poniendo el acento en el modo en que la androginia se erige como una forma de estilo crítico antes que como una condición genital (hermafroditismo) o una inversión de los roles masculinos y femeninos (travestismo). Seguidamente analizaré, en el cuarto apartado, el potencial crítico de la androginia en tanto ideal metafísico y político. Especialmente a partir de las tesis de la feminista canadiense Shulamith Firestone, presentaré la androginia como una suerte de enclave crítico corporal especialmente dirigido contra el binarismo esencialista y las jerarquías que se siguen de dicho binarismo. Posteriormente, discutiré algunas manifestaciones estilísticas andróginas, o más precisamente, pasaré revista de ciertos usos profanos de las prendas desde las expresiones antiguas protoandrógina en algunos rituales y experiencias culturales, hasta la aparición de elementos andróginos en lo unisex, en la estética camp y en algunos otros fenómenos culturales contemporáneos como los estudiados por el crítico uruguayo Roberto Echavarren. Por último, concluiré haciendo referencia al tema -discutido por algunos teóricos y teóricas-, de una posible relación del andrógino con el tema de lo cibernético.

Mi intención, en última instancia, consiste entonces en abordar la androginia como un ideal inicialmente metafísico que no obstante ha derivado en algunas apropiaciones estilísticas con una cierta dimensión utópica. La androginia, así, será conceptualizada no solo en términos de una simbólica, sino también como un criterio ético capaz de nutrir ejercicios críticos que apelan al aspecto y al trabajo con el cuerpo. 


\subsection{La androginia mítica}

El andrógino aparece con un cierto grado de resonancia especialmente a partir de la filosofía platónica. Si bien, como lo señalan los comentadores, la androginia aparece en corpus platónico de un modo ciertamente periférico, o al menos al servicio de otras tesis consideradas más centrales -véase al respecto, por ejemplo, la opinión de Rowe (1998, 34)- lo cierto es que la filosofía platónica establece un punto de referencia en lo relacionado a la androginia.

No obstante, el andrógino platónico no es el primero de la historia. En su obra El mito del andrógino ([1980 2001) el filósofo francés Jean Libis señala al respecto que la androginia platónica tiene un antecedente inmediato en el pensamiento de Empédocles (Libis, [1980] 2001, 78). Freud, por su parte, indica asimismo que probablemente Platón habría sido influenciado por libros hinduistas del siglo VII a.c en los que se habla de un ser maravilloso formado por una parte masculina y una femenina a partir de cuya división se crean los seres sexuados (Freud, [1920] 2013, 2538). El historiador de la filosofía antigua W.K.C. Guthrie coincide con estas perspectivas, y agrega que el tema de la androginia podría haber aparecido en la filosofía de Platón debido no solo a la influencia de ciertos relatos mitológicos, sino también por motivo de la presencia de lo andrógino dentro de algunas explicaciones propias de la filosofía natural de la época (Guthrie, [1962] 1990, 369-370). En todo caso, el relato que Platón pone en boca de Aristófanes en el Banquete se impone como un texto fundacional en lo referido a la cuestión andrógina. Según dicho relato

[...] nuestra antigua naturaleza no era la misma de ahora, sino diferente. En primer lugar, tres eran los sexos de las personas, no dos, como ahora, masculino y femenino, sino que había, además, un tercero que participaba de estos dos, cuyo nombre sobrevive todavía, aunque él mismo ha desaparecido. El andrógino, en efecto, era entonces una sola cosa en cuanto a forma y nombre, que participaba de uno y de otro, de lo masculino y de lo femenino, pero que ahora no es sino un nombre que yace en la ignominia (Banquete, 189d-189e). 
Como se sabe, Platón se sirve de esta narración para, a partir de ella, dar cuenta de forma alegórica del deseo sexual y aún de la propia estructura morfológica del cuerpo (órganos sexuales incluidos). Según el Aristófanes platónico, Zeus castiga la pretensión de estos seres compuestos de dos brazos y dos piernas de querer subir a los cielos para asemejarse a los dioses, en razón de lo cual les corta en dos mitades. De esas dos mitades, según el relato platónico, surgen precisamente el cuerpo masculino y femenino. También a partir de esa escisión originaria es que aparece el deseo erótico: las mitades cortadas, en efecto, se buscan una a la otra en aras de restituir su composición originaria y es en razón de ello, prosigue Aristófanes, que algunas mitades masculinas buscan mitades femeninas (en el caso de los seres originalmente andróginos), mientras que otras mitades buscan cuerpos de su propio sexo, toda vez que originalmente estaban unidas a ellas. De este modo, el mito descrito por Aristófanes aparece como un intento de explicar no solo las dinámicas genéricas de atracción sexual sino también el propio origen del deseo erótico, entendido como reunión o restitución de una idealidad perdida.

Coño señalé antes, en el contexto del conjunto del texto platónico en cuestión la fábula aristofánica se ha leído en la mayoría de ocasiones como el retrato de un momento degradado del ascenso ontológico hasta el verdadero Eros (un Eros que, como se sabe, está relacionado para Platón con el conocimiento de las ideas y de la belleza en sí). Rowe, por ejemplo, indica que la descripción fenomenológica que Aristófanes realiza de Eros en el Banquete se limita a allanar el camino para el ulterior discurso que Sócrates realiza inspirado en Diótima (Rowe, 1998, 34). Incluso los comentadores discuten hasta qué punto el discurso aristofánico no posee una naturaleza cómica, apelando al dato de que el mito andrógino es puesto en el diálogo en cuestión en boca del que fuera uno de los más conocidos comediantes antiguos. ${ }^{59}$

Sin embargo, otros autores arriesgan la interpretación de que el pasaje platónico en el que se alude a lo andrógino posee una especial resonancia pese a su lugar marginal dentro de la organización general del texto. Jean Libis aventura en este sentido la tesis de que aún cuando tras la disertación aristofánica, el relato platónico "nos arrastra (...) más allá de

${ }^{59}$ Véase al respecto Guthrie ([1962] 1990, 370) y Rowe $(1998,34)$. 
los artificios seductores de la sola sensualidad del cuerpo, (...) la fábula relatada por Aristófanes constituye (...) un momento esencial del conjunto del relato" (Libis, [1980] 2001, 15). ${ }^{60}$ Para el comentarista francés, en efecto,

[...] la seducción que dicha fábula ejerce sobre el lector tiene una especie de virtud hipnótica, hasta el punto de que a veces la intervención del poeta cómico aparece como el centro de gravedad del libro, a espaldas sin duda de la intención específica de Platón (Libis, [1980] 2001, 15).

De hecho, la influencia del texto que Platón pone en boca de Aristófanes permea la mayoría de los discursos posteriores que aluden a la figura del andrógino. Libis se refiere en este sentido a una "plasticidad del esquema de la androginia" (Libis, [1980] 2001, 15). El mito andrógino, desde esta perspectiva, posee resonancias no solo en el ámbito de las cosmogonías, las religiones y el gnosticismo, sino también en el campo literario y científico. ${ }^{61}$ De todas maneras, resulta claro que la recepción del imaginario andrógino en todos estos registros no se da de una manera idéntica y que la androginia, en tanto núcleo cultural, desborda ampliamente la androginia platónica propiamente dicha.

Jean Libis señala a este respecto que es posible distinguir tres grandes focos de afluencia del mito andrógino más allá de Platón. Por un lado, existiría una matriz de corte cosmológico/teológico que bebería de la simbólica andrógina. En este frente se contarían los múltiples relatos divinizantes del andrógino que replicarían la imagen platónica de este ser como uno que aspira a asimilarse a los dioses o bien que posee una cierta gracia sobrehumana. Asimismo, dentro de este registro se encuentran explicaciones sobre el origen del universo en las cuales tienen lugar fusiones e hibridaciones de elementos masculinos con elementos femeninos. Dentro de este primer gran grupo, en el cual abundan asimismo relatos sobre la caída o la pérdida de un estado ideal en el pasado, Libis incluye la tradición hermética, el neoplatonismo, el gnosticismo y otras variantes místicas, e incluso habla con Mircea Eliade de una "vocación universalista del esquema

\footnotetext{
${ }^{60}$ Sobre las exégesis históricas del Banquete y su menosprecio del momento andrógino de dicho texto véase Libis ([1980] 2001, 208).

${ }^{61}$ Idéntica opinión expresa el filósofo y escritor costarricense Jorge Jiménez, quien encuentra la impronta del relato andrógino platónico en matrices tan disímiles como el psicoanálisis, la literatura y plástica decimonónicas, el imaginario cristiano y la literatura beat (Jiménez, 1996).
} 
andrógino" (Libis, [1980] 2001, 68). En segundo término, el autor señala una presencia del imaginario andrógino en el marco de explicaciones antropológicas. En tal sentido, la figura del andrógino emerge como una suerte de Gran Antepasado o un Ser Primordial pretérito. Aquí la separación de los sexos aparece como un hecho traumático evocando la intervención "quirúrgica" de Apolo en el Banquete al separar los seres duales originarios entre los cuales figuraba el andrógino. Libis incluye dentro de este segundo espectro de discursos relacionados con la androginia una serie de relatos mitológicos provenientes de Malí y de la zona escandinava -entre otros- que hablan de un Hombre (sic) Primordial. Por último, el teórico francés se refiere a una androginia que podría denominarse sociológica. Se trata de una serie de manifestaciones rituales y de explicaciones científicas en las cuales el andrógino adquiere una cierta plausibilidad empírica o algún grado de comprobabilidad histórica, esto es, experiencias en las cuales la androginia se manifiesta ya fuere como transgresión a través de cuerpos concretos o como elemento susceptible de ser hallado en la realidad a partir de marcos científicos o etnográficos.

Sin duda, estos tres planos se encuentran a menudo superpuestos, y es corriente que una misma manifestación andrógina exprese o sintetice elementos de varios de ellos o de la totalidad de los mismos. En todo caso, como lo señala la arriesgada interpretación de Libis, pese a este carácter caleidoscópico de la mitología androginia, no debe olvidarse su connotación persistentemente sexual y su impulso transgresor ([1980] 2001, 207). El andrógino, de hecho, remite al binarismo sexual en términos de un orden que no es estrictamente único ni necesario:

[...] acumulando los sexos, o más bien anulándolos con mucha frecuencia al superarlos en una sutil síntesis, el arquetipo andrógino, ¿no implica fundamentalmente el deseo de negar la diferencia de los sexos (...) y de abolir al mismo tiempo el drama ontológico que a partir de allí se desarrolla? Desde esta perspectiva, ¿no habría que considerar que el mito andrógino es, en su esencia fundamental, como el negativo de la sexualidad? (Libis, [1980] 2001, 203).

Es precisamente esa veta negativa del andrógino -o su dimensión "ontológicamente escandalosa", como la llama en otro momento de su obra Libis ([1980] 2001, 22)- la que quisiera poner más adelante en relación con los cuerpos y el tema del vestido. A partir 
de esta voluntad de quebrantamiento de la mitología andrógina en relación con el esencialismo y sus sexos estancos, me interesa mostrar, precisamente, que la androginia, al devenir estilo indumentario, es capaz de desplegar con y a través del cuerpo, una crítica política. Pero primero habrá que dar cuenta del modo polémico en que la androginia se trenza con explicaciones sobre la sexualidad por fuera del registro mítico para alcanzar a expresarse como una androginia acaso más empírica, para lo cual será necesario, a continuación, centrar la atención momentáneamente en la recepción freudiana del mito platónico.

\subsection{De la disposición perversa polimórfica a la sustancia viva escindida: los avatares de la androginia platónica en el psicoanálisis freudiano}

Con Freud, el andrógino platónico se asienta con una mayor intensidad en el cuerpo. ${ }^{62}$ Esto es: el andrógino platónico gana en Freud una mayor densidad ontológica al devenir supuesta condición real, aunque pretérita, de los cuerpos. No obstante, como mostraré, se trata de una encarnación no exenta de problema ni completamente divorciada del mito.

El interés de parte del psicoanálisis en el mito platónico del andrógino se pone en evidencia a través de varios pasajes del corpus freudiano. En primera instancia, Freud se ocupa del mito platónico en su célebre texto de 1905 intitulado Tres ensayos para una teoría sexual. Dicho texto, avocado a construir una teoría sexual que explicara tanto la constitución de la sexualidad normal como las correspondientes desviaciones de la misma, sostiene, como se sabe, la hipótesis de que el carácter sexuado de los infantes contiene en ciernes $-\mathrm{y}$ por lo tanto determina- la sexualidad adulta. Para Freud, la negación teórica del carácter sexuado del cuerpo infantil proyecta oscuridad en torno a la dilucidación de las dinámicas sexuales adultas así como en torno a la explicación de cómo el ser humano deviene sujeto deseante -dejaré de lado acá las pertinentes críticas de teóricos como Deleuze y Guattari, Foucault e Irigaray (entre otros) respecto del modo

\footnotetext{
${ }^{62}$ Para una comparación general de las posiciones platónica y freudiana así como de las distintas versiones históricas a propósito de las similitudes y diferencias entre dichas posiciones, véase Marí (2001, 239-286). El autor, sin embargo, no toma la androginia como un eje de su análisis.
} 
en que Freud finge limitarse a describir el cuerpo sexuado del niño cuando, en realidad, prescribe una cierta utilización de dicho cuerpo así como una sexualidad normalizada; véase al respecto especialmente Deleuze y Guattari ([1972] 1985, 79), Foucault ([1999] 2002, 245-268) e Irigaray ([1974] 1978, 24-145), así como mis propios comentarios sobre las limitaciones de la concepción psicoanalítica del cuerpo en los capítulos 1 y 3-. En este contexto, Freud se refiere a un "instinto sexual", el cual funcionaría en relación con el deseo erótico del mismo modo que el instinto de nutrición opera en relación con el hambre (Freud, [1905] 2013, 1172). Este instinto, el cual Freud denomina libido, carece sin embargo de una explicación en términos de su génesis. A saber: según Freud, la opinión popular se limita a ver en el deseo sexual un proceso que se constituye en la madurez, sin tener en cuenta que la libido es connatural a lo humano desde su propia gestación. Así, la disposición libidinal de los individuos responde simultáneamente a una predisposición biológica que, no obstante, se ve moldeada en distintos grados por la cultura según sea la interpretación que se haga de la letra freudiana -en diversas ocasiones se ha señalado, de hecho, el modo en que los Tres ensayos para una teoría sexual conjugan observaciones biologicistas con visiones construccionistas sobre lo sexual, con una propensión bastante mayor hacia las interpretaciones biologicistas, al menos si nos atenemos a la opinión de la perspectiva posestruturalista que he empleado a lo largo de este trabajo; véase a manera de ejemplo de este tipo de interpretaciones Butler ([1990] 2007 88-89)-.

En todo caso, lo que me interesa subrayar es el rol que la androginia pasa a ocupar en el contexto de esta reflexión freudiana. Si la androginia platónica se movía todavía dentro de un magma discursivo aún marcado por el mito, para Freud, en cambio, la configuración anatómica andrógina se erige como hipótesis verosímil en lo tocante a la configuración real de los cuerpos. Pero si la androginia constituye el punto de partida de la vida sexuada de lo individuos, ¿cómo es que de esa disposición inicial se derivan los sexos? 
Dada la envergadura de la pregunta, así como la pretensión freudiana de cientificidad, el mito platónico emergerá en la teoría freudiana revestido de una cierta plausibilidad epistémica:

[...] en lo que se refiere a la "ampliación" del concepto de sexualidad, impuesta por el análisis de los niños y de los denominados perversos, recordaré a cuantos contemplan desdeñosamente el psicoanálisis desde su encumbrado punto de vista cuán estrechamente coincide la sexualidad ampliada del psicoanálisis con el Eros divino de Platón (Freud, [1905] 2013, 1171).

La relación de Freud con el Eros platónico es entonces, primero, una relación de filiación. No obstante, como señalaba antes, se trata también de una lectura que intenta ver en la androginia un estado corporal real del ser humano. De este modo, en su descripción del recorrido que sigue el cuerpo sexuado del niño hasta llegar a constituirse en el cuerpo del adulto, tiene lugar dentro del texto freudiano una expresa similitud con el esquema platónico. Freud, en efecto, hace derivar el deseo sexual de un cuerpo originario asexuado con ciertos rasgos andróginos. ${ }^{63}$ Se trata de lo que el psicólogo vienés denomina la "disposición perversa polimórfica" (Freud, [1905] 2013, 1205). A saber: según Freud, en el niño, en su más temprana edad, tiene lugar una suerte de disposición multiforme para el placer, capaz de seguir innumerables trayectorias sin un objeto definido.

Ahora bien, lo que resulta significativo para los efectos de la presente investigación es el hecho de que el niño perverso polimórfico carezca de un sexo definido. Para Freud, el niño, pese a poseer una propensión al placer, carece, ciertamente, de caracteres definitivamente masculinos o femeninos. No es sino hasta después de lo que Freud denomina la fase sádico-anal, con la consecución de un objeto de deseo sexual y posteriormente con la pubertad, que el sujeto se hace con uno de los sexos y que, por ende, consolida una identidad psíquica sexuada (por lo demás, de claros rasgos normativos: se trata de una heterosexualidad restringida al coito, genitocéntrica y dirigida unilateralmente a la consecución del orgasmo masculino y la procreación; allende esta configuración Freud habla, de hecho, de "anormalidades" e "inversiones"). El perverso

${ }^{63}$ Para un enfoque crítico de este punto de la argumentación freudiana véase Hocquenghem $(2009,73)$. 
polimórfico, en suma, es un ser sin un sexo todavía debidamente constituido: el clítoris y el pene -nótese desde ya el carácter genitalizante de lectura freudiana de Platón- están aún insuficientemente indiferenciados (aunque, como lo señala atinadamente Irigaray, la concepción freudiana del clítoris como un pequeño pene ya supone un nivel de diferenciación ontológica entre el cuerpo del niño y el de la niña y una concepción misógina de dicha diferencia; véase mi comentario al respecto en el apartado 2.4).

De este modo, al desplazar el tema de la androginia desde el registro mítico hasta el registro psicoanalítico, Freud hace del andrógino platónico un niño polimórficamente perverso: el cuerpo sexuado del niño polimórfico es, en efecto, el equivalente del andrógino platónico; ambas figuras, por otra parte, cumplen la función de explicar la génesis del cuerpo sexuado y el deseo. De idéntica manera que en el relato del Aristófanes platónico, la cópula aparecerá así igualmente ligada, según el psicólogo vienés, al deseo de restituir un estado primigenio previo a la separación. Pero mientras en el caso de Platón dicha separación tenía lugar por efecto de la intervención de los dioses, en el caso de Freud, en cambio, el trauma de la escisión tiene lugar, en primera instancia, con el nacimiento y la correspondiente salida del útero, y en segunda, con la separación del pecho materno.

Los derroteros del deseo freudiano se encuentran así marcados por su lectura de Platón. En síntesis, Freud considera que en la constitución polimórficamente perversa del infante se encuentran potencialmente las distintas trayectorias posibles en relación con la elección del objeto de deseo. Del mismo modo que el andrógino platónico explica el porqué de la atracción hacia uno u otro sexo, el esquema freudiano, por otra parte, pretende explicar por intermedio de un esquema regresivo el modo en que la homosexualidad, la bisexualidad y la heterosexualidad se siguen de la disposición inicialmente polimórfica del niño.

En un ensayo posterior titulado Más allá del principio del placer ([1920] 2013), Freud vuelve al tema de la androginia platónica desde un punto de vista ligeramente distinto aunque ciertamente complementario con el anterior. En este segundo escrito, el psicólogo 
aborda de nuevo el problema del origen del principio del placer, pero esta vez interrogándose a propósito de si existe algún factor que incida en la vida anímica más allá de dicho principio o si, por el contrario, el mismo explica la totalidad de la vida psíquica del individuo. No obstante, en lugar de centrarse en el cuerpo sexuado, en este caso Freud intenta abordar la problemática en cuestión desde un punto de vista orgánico. Esto es: según este ensayo, el instinto no está ya únicamente ligado al deseo sexual, sino que, por el contrario, dicha noción designa "una tendencia propia de lo orgánico vivo a la reconstrucción de un estado anterior" (Freud, [1920] 2013, 2525). Lo que antes era propiedad de los cuerpos en tanto y en cuanto estos experimentan placer erótico, ahora deviene también propiedad asexuada de la materia orgánica. La libido, por lo tanto, aparece en este contexto ligada a la sobrevivencia y a la posición antagónica que ocupa el instinto de vida en relación con el instinto de muerte.

En todo caso, la pregunta que Freud pretende contestar a partir del mito platónico en esta segunda obra es qué explica la génesis de Eros, considerado este último concepto en su dimensión metabiológica, es decir, como fuerza que hace a la materia tender a su autoconservación. En otras palabras, lo andrógino aparece acá en un registro si se quiere más metafísico (evocando levemente las antiguas cosmogonías andróginas), para explicar el modo en que Eros reúne lo separado, engendrando así lo vivo. La androginia originaria funciona en tal sentido a la manera de una hipótesis verosímil (aunque Freud no deja de notar, no sin algún grado de incómodo nerviosismo, que se trata de un mito) para explicar la repetición orgánica de los comienzos de la vida humana. El Eros platónico, releído por Freud, opera ahora como un principio metafísico que restituye a la materia su estructura primigenia. El Eros, así, resulta una respuesta de la sustancia viva animada a las separaciones que el entorno natural provoca. De ahí que Freud hable de un “instituto de reunión” (Freud, [1920] 2013, 2538): el placer es aquello que, al igual que en el mito platónico, mueve a los amantes (¡y a la materia misma!) a reunir lo separado. Señala el autor:

[...] es tan poco lo que la ciencia nos dice sobre la génesis de la sexualidad, que puede compararse este problema con unas profundísimas tinieblas, en las que no ha penetrado aún el rayo de luz de un hipótesis. En otro sector, completamente 
distinto, hallamos una de tales hipótesis, pero tan fantástica -más bien un mito que una explicación científica-, que no me atrevería a reproducirla aquí si no llenase precisamente una condición a cuyo cumplimiento aspiramos (...). Me refiero, naturalmente, a la teoría que Platón hace desarrollar a Aristófanes en el Symposion (Freud, [1920] 2013, 2537).

Freud vuelve a introducir, de este modo, la androginia mítica platónica dentro de un discurso que reclama para sí el estatuto de ciencia. La androginia se convierte, así, en algo más que una hipótesis sobre el origen del deseo, y deriva en una suerte de cosmogonía metabiológica que intenta dar cuenta del comportamiento de la materia. Tras transcribir el pasaje aristofánico del texto platónico, Freud, en efecto, plantea a partir del mismo una serie de preguntas:

[...] ¿Deberemos acaso, siguiendo a los filósofos poetas, arriesgar la hipótesis de que la substancia viva sufrió al ser animada una fragmentación en pequeñas partículas, que desde entonces aspiran a reunirse de nuevo por medio de los instintos sexuales? ¿Y que estos instintos, en los cuales se continúa la afinidad química de la materia inanimada, van venciendo poco a poco, pasando primero por el reino de los protozoarios, aquellas dificultades que a esta tendencia opone lo circundante, cargado de excitaciones que pone en peligro la vida y los obligan a la formación de una capa cortical protectora? ¿Y que -por último- tales fragmentos de sustancia viva alcanzan de este modo la multicelularidad y transfieren, en fin, en gran concentración el instinto de reunión a las células germinativas? (Freud, [1920] 2013, 2538).

Naturalmente, frente a la envergadura epistemológica y a las consecuencias metafísicas de tales preguntas, Freud vacila en adherir sin condiciones a la explicación platónica. No obstante, lo cierto es que mediante este giro, el polimórfico perverso deviene sustancia viva: la androginia platónica ha recorrido un trayecto dentro del corpus freudiano del ámbito de la anatomía sexuada al campo de la materia y la vida celular (no sin guardar, no obstante, una relación con el tema del placer y de lo erótico). Los dos ensayos, sin embargo, recurren a la androginia platónica insertándola dentro de un contexto epistemológico distinto y asignándole ahora el estatuto de hipótesis plausible.

Ambas versiones freudianas del mito platónico resultan, por ende, pertinentes para los efectos de esta investigación. En primer lugar, por el hecho de que Freud busca exiliar la 
androginia del registro mítico. Con Freud, en efecto, la androginia deviene característica de los cuerpos y la materia, y no ya únicamente constructo mitológico. Mediante su lectura de la androginia en un contexto sexológico primero, y metabiológico después, Freud instala la androginia en el cuerpo y la despega, asimismo -aunque ciertamente no del todo-, del ámbito de la fábula. Aquí, sin duda, la androginia está lejos de designar un estilo o un ethos corporal -sobre todo, como argumentaré, debido a su equívoca reducción a una condición genital-, pero sin duda se trata de un procedimiento teórico importante en relación con mi objetivo de este capítulo, en la medida en que Freud acerca la androginia a la vida corporal y a la posibilidad de pensar distintas configuraciones allende el binarismo sexual. En segundo lugar, Freud acentúa la conexión platónica entre la androginia, el binarismo sexual y la configuración del deseo. Esta relación, como podrá advertirse, es de suyo significativa en términos de concebir la androginia como una expresión estilística: si los cuerpos andróginos, como lo plantea Jean Libis, dan cuenta de "una inquietud arcaica del hombre (sic) respecto de su condición sexual" (Libis, [1980] 2001, 254), la androginia podría leerse, no ya como un estado primigenio capaz de soldar metafórica y mitológicamente a los sujetos con un sexo y una orientación sexual específicos, sino de introducir un cortocircuito (o explosión, como lo diría Shulamith Firestone) dentro de dicho continuum (operación para la que el victorianismo de Freud constituía, sin duda, todavía un obstáculo insuperable). En otras palabras, si para Freud, el sexo queda fijado al cuerpo a partir del abandono de una androginia primigenia, ello posibilita formular la interrogante de qué ocurriría si esa androginia persistiera a la manera de un núcleo pertinaz que insiste en perfilar las actuales configuraciones del cuerpo y el deseo como configuraciones aleatorias o contingentes (véase al respecto el apartado siguiente). De hecho, la hipótesis andrógina obliga a Freud, pese a sus insistentes referencias patologizantes de la homosexualidad, sus marcados sesgos masculinistas y su pertinaz vocación normativa, a admitir el carácter hasta cierto punto abierto en el proceso de construcción de la diferencia sexual y de la elección de objeto(s) de deseo. Desde este punto de vista, la androginia aparece, entonces, como una forma corporal que sería capaz de abrir zonas de indeterminación libidinal, de desarticular dispositivos de normalización y de poner en entredicho la necesariedad del binarismo sexual. En una palabra: la androginia irrumpe, aún dentro de marcos discursivos que 
pretender asignarle un orden a los cuerpos y al deseo, como un elemento de desestabilización, o al menos como una puerta tras la cual se adivinan otros placeres y cuerpos posibles. No obstante, para analizar esa posibilidad en toda su dimensión, es preciso ir más allá de la recepción genitalizada que Freud realiza de Platón, y examinar la androginia en tanto fenómeno corporal propiamente estilístico. En otras palabras, es menester pasar del cuerpo polimórficamente perverso del niño y de la materia orgánica reunida por Eros, a una androginia más cercana al cuerpo vestido.

\subsection{La androginia y la crítica a los géneros}

A partir de Freud, la androginia quiere entonces rebasar el discurso mítico para entrar en la esfera del cuerpo humano "real". Pero mediante ese mismo movimiento, la androginia pareciera acabar reducida a un tipo de configuración anatómica caracterizada por la indeterminación genital. Si el perverso polimórfico es para Freud un cuerpo todavía no acabadamente sexuado (pero que para alivio del victorianismo del autor llegará a estarlo en etapas posteriores) la recepción freudiana de Platón pareciera por lo tanto estar marcada por una circunscripción de la androginia al ámbito de los órganos sexuales. La androginia, para Freud, remite a los cuerpos y a la materia, pero todavía no al estilo ni a la disrupción.

En esta línea, Freud hace referencia en sus Tres ensayos para una teoría sexual al tema del hermafroditismo, poniendo en un mismo plano androginia y hermafroditismo (operación que, por mi parte, rechazaré: me detendré, de hecho, a establecer las

diferencias entre uno y otro concepto más adelante en este mismo apartado). "La ciencia conoce -señala el fundador del psicoanálisis- casos en los que los caracteres sexuales aparecen borrosos, dificultando la determinación del sexo ya en el terreno anatómico. Los genitales de estos sujetos de sexo indeterminado reúnen caracteres masculinos y femeninos (hermafroditismo)" (Freud, [1905] 2013, 1176). No obstante, la condición hermafrodita no es, según Freud, enteramente ajena al individuo común: “en ningún individuo masculino o femenino, normalmente desarrollado, dejan de encontrarse huellas 
del aparato genital del sexo contrario", por lo cual, prosigue el autor, "cabe hablar de una disposición bisexual originaria, que en el curso de la evolución se ha ido orientando hacia la monosexualidad" (Freud, [1905] 2013, 1176). Así, la androginia corporal platónica, devenida en Freud en la figura del niño polimórfico perverso, pareciera confundirse asimismo con la figura del hermafrodita. ${ }^{64} \mathrm{El}$ andrógino se ha abierto campo en el discurso sobre los cuerpos, pero a condición de que su carácter sexualmente indeterminado se restringa a su condición genital.

En realidad, Freud se encarga de insertar la androginia platónica dentro del discurso biomédico y sexológico dominante en su época. La idea de que la androginia es reductible a la condición genital de un hermafroditismo solo difusamente conectado con la psique convierte la condición andrógina en una de relativamente fácil domesticación. En otras palabras, si la androginia acaba subsumida dentro de un estado inicial de hermafroditismo diluido posteriormente a lo largo de la evolución del "individuo normal", el andrógino freudiano pareciera inofensivo en relación a un binarismo que no solo constituye su trascendencia, sino que también lo rebaja a la condición de portento médico. La operación es, en cierto sentido, analogable al procedimiento platónico, toda vez que en ambos casos se hace derivar la polaridad masculino/femenino de una androginia originaria para ulteriormente asignar a uno de los sexos una superioridad sobre su opuesto - no debe olvidarse, por ejemplo, que las mitades masculinas que buscan su mitad masculina tras la escisión perpetrada por Zeus son calificados por Platón en su relato como audaces, valientes y aptos para la vida política, mientras las mitades femeninas que buscan su mitad femenina son aludidas por Platón sencillamente como lesbianas (Banquete, 191e-192b)-.

Siguiendo al historiador del sexo Thomas Laqueur, podría decirse, de hecho, que tanto Platón como Freud incorporan la figura del andrógino para más tarde acabar ajustando dicha figura a los parámetros de género de sus propias épocas, los cuales se corresponden, grosso modo, con las dos concepciones históricamente dominantes en lo

\footnotetext{
${ }^{64}$ Es menester señalar a este respecto que, en el niño polimórfico perverso, clítoris y vagina no se encuentran aún diferenciados, por lo que cabe hablar de una cierta asimilación entre dicha figura y la del cuerpo bisexuado originario
} 
que respecta a las explicaciones sobre la diferencia sexual. Según Laqueur, en efecto, la relación entre cuerpo y género habría estado marcada históricamente hablando por dos modelos: el del sexo único y el de los dos sexos. Por modelo de sexo único Laqueur entiende no un universo discursivo y cultural desinteresado en las diferencias de género, sino, por el contrario, uno donde esas diferencias se juegan en un ámbito metafísico -a partir de oposiciones maniqueas entre por ejemplo frío/caliente o racional/irracional- que solo ulteriormente se proyectan en el cuerpo. En otras palabras, en el modelo unisexo las diferencias no parten del cuerpo sino que solo se reflejan en él, motivo por el cual las disimilitudes entre los cuerpos masculinos y femeninos son solo de grado -por supuesto, el autor observa el hecho de que ese continuum entre la anatomía femenina y la masculina no estaba exenta de jerarquizaciones: al interior de dicho continuum, por el contrario, existía una clara jerarquía de lo masculino sobre lo femenino, al punto de que los órganos de las mujeres se consideraban inversiones de los del varón; en consecuencia, dichos órganos eran designados con las mismas palabras utilizadas para hacer referencia a las partes masculinas: Galeno, por ejemplo, concebía las mujeres como varones “doblados hacia adentro" (Laqueur, [1990] 1994, 56)-. En una palabra: la diferencia anatómica entre los sexos constituía, dentro del modelo unisexo, un epifenómeno, mientras que la verdadera fuente de distinción entre lo masculino y lo femenino procedía de un orden cósmico.

El modelo de los dos sexos, en cambio, afirma una diferencia sexual que ya no se inscribe en un eje vertical con indefinidas gradaciones como en el caso del sexo único, sino más bien en un eje horizontal dicotómico anclado en el cuerpo y sus órganos. Se trata, en otras palabras, de la diferencia sexual tal y como se concibe actualmente dentro de los discursos biomédicos. En opinión de Laqueur, dada la coexistencia histórica de estos dos esquemas, es plausible sostener que el sexo no precede al género (Laqueur, [1990] 1994, 397-413) -en razón de lo cual, como he sostenido a lo largo de la presente investigación, dispositivos como el vestido resultan de una centralidad fundamental-. Para el autor, históricamente hablando, de hecho, 
[...] casi todo lo que se desea decir sobre el sexo -como quiera que se entienda este- ya ha sido reivindicado para el género. El sexo, tanto en el mundo de un sexo como [en] el de dos sexos, depende de su situación; solo puede explicarse dentro del contexto de las batallas en torno al género y el poder (Laqueur, [1990] 1994, 33).

Volviendo a las concepciones platónica y freudiana de la androginia, pareciera, siguiendo a Laqueur, que ambas pactan con el binarismo desde el mismo momento de su gestación teórica. Vistas desde la perspectiva de Laqueur, en efecto, una y otra androginia parecieran del todo compatibles con las políticas de género dominantes en cada una de sus épocas, si bien en uno y otro caso la introducción de la figura del andrógino incorpora consecuencias tan imprevistas como políticamente interesantes -en el caso de Platón, por ejemplo, el relato aristofánico es el único de toda la literatura ática en reconocer la existencia de la homosexualidad femenina, mientras que en el caso de Freud, el elemento andrógino abre un portillo para pensar la heterosexualidad como algo no menos natural que la homosexualidad (Freud, [1905] 2013, 1178)-. Así, según Laqueur, mientras que dentro del relato platónico, la androginia, inscrita inequívocamente en el modelo unisexual, hace referencia a una explicación mitológica acerca del origen común de lo masculino y lo femenino (Laqueur, [1990] 1994, 105), la androginia freudiana hace parte, en cambio, de un esfuerzo moderno por instalar en el cuerpo, y especialmente en los genitales, el origen de las diferencias entre los sexos (Laqueur, [1990] 1994, 397). En uno y otro caso, por lo tanto, se introduce la androginia sin un ánimo de polemización en relación con los parámetros epocales de género. La androginia platónica, así, subraya el origen común de los sexos y la raigambre más bien cósmica de la diferencia entre ellos, mientras que Freud enfatiza las diferencias genitales. No obstante, desde la perspectiva de Laqueur, ambos autores inscriben la figura del andrógino dentro de modelos en los que lo femenino acaba siendo subordinado luego de la pérdida de la androginia primigenia.

En mi opinión, esta absorción de la figura del andrógino dentro de las distintas formas de binarismo sexual descritas por Laqueur ocurre toda vez que se trata de androginias todavía desligadas del tema del estilo. Según creo, en efecto, la androginia no tiene porqué quedar reducida a un giro retórico o alegórico -como en la filosofía platónica- ni a su dimensión genital -como lo quiere Freud-. De hecho, creo necesario perfilar la 
androginia, en tanto despliegue de una forma corporal no binaria, como una condición separada de lo anatómico. En este sentido, me parece que Freud comete un error al asimilar la androginia al hermafroditismo. En efecto, mientras que la androginia designa, a mi modo de ver, un modo de trabajar el cuerpo que intenta borrar las huellas del disciplinamiento de género, el hermafrodita, en cambio, obtiene su especificidad directamente de la forma de sus órganos sexuales. En el propio discurso médico, proclive a mezclar parcialmente ambos fenómenos (probablemente en virtud del hecho de que de esa forma la androginia deviene más fácilmente legible como síntoma) se deslizan, de hecho, algunas diferencias. Efectivamente, mientras que el andrógino es definido por un texto de consulta médico actual como una "persona que tiene algunas características de ambos sexos [y en la que] el papel social, la conducta, la personalidad y el aspecto son un reflejo de la individualidad y no están determinados por el sexo" (Gispert, 1997, 61), el hermafroditismo, en cambio, es definido en esa misma fuente como un "trastorno raro en el que coexiste en la misma persona tejido ovárico y tejido testicular [y que] se debe a una anomalía cromosómica" (Gispert, 1997, 655). Otro texto médico define asimismo al andrógino como un "seudohermafrodita (...) que no representa caracteres sexuales definidos" (Venes, [2005] 2007, 72), mientras que el hermafrodita propiamente dicho es definido como un "sujeto que posee características genitales y sexuales de ambos sexos" (Venes, [2005] 2007, 72). El plano etimológico provee asimismo elementos para recortar

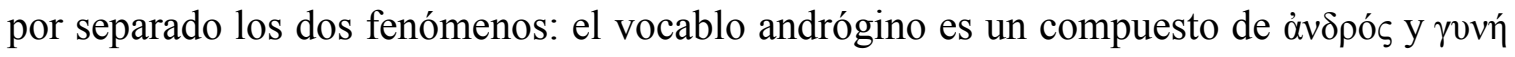
haciendo manifiesta la mezcla y la superposición de elementos masculinos y femeninos en general (Corominas, 1961, 50), mientras que la noción de hermafrodita hace referencia, como se sabe, a Hermafroditos, personaje de la mitología griega cuya ambigüedad sexual se arraigaba más fuertemente en la anatomía (Corominas, 1961, 312). En una palabra: la androginia no es reductible al ámbito genital como lo quiere Freud, en la medida en que ella remite al cuerpo vestido como soporte de sentido y como enclave decodificador de conductas y roles sociales. ${ }^{65}$

\footnotetext{
65 Jiménez también considera la androginia -en tanto fenómeno político y estético- como una manifestación irreductible al hermafroditismo -más ligado a la biología y la anatomía-. Véase Jiménez (1996, 227-229).
} 
Mediante esta distinción se hace más clara la relación de la androginia con el tema del presente escrito. A mi modo de ver (aunque en este punto sigo la perspectiva de Echavarren), la androginia se encuentra vinculada, en efecto, con la posibilidad de emplear críticamente el cuerpo y las prendas en relación con las normativas vestimentarias regulatorias del género. En este sentido, lo andrógino deviene estilo y remite de forma directa al ámbito de la indumentaria. En términos generales, creo que puede hablarse de estilo andrógino cuando la vestimenta se emplea para poner en evidencia el carácter arbitrario -y según Echavarren, anacrónico- del dimorfismo sexual. Al contrario del mito andrógino platónico y del hermafrodita y el polimórfico perverso freudiano, el estilo andrógino, en este sentido, no se refiere a la restitución de una idealidad perdida, sino más bien el inevitable fracaso al que está condenada toda idealización de la diferencia sexual. En el estilo andrógino la presentación y el aspecto se utilizan, por tanto, como instancias de superación de la anatomía: frente a la medicalización genitocéntrica a la que pareciera condenado el hermafrodita, el andrógino condensa, mediante la yuxtaposición de prendas, la posibilidad de una estilización de lo ambiguo, lo indeterminado y lo inclasificable. En tal sentido, cabe pensar el estilo andrógino no en un sentido de reunión o de un cese de las diferencias, sino como un enclave estilístico para la crítica ontológica de las jerarquías que se siguen de dichas diferencias (ampliaré las características del estilo andrógino más adelante).

El estilo andrógino, en este sentido, tampoco debe confundirse con el travestismo (otra forma de estilo igualmente sugerente y rica políticamente hablando). Si en el travestismo también tienen lugar ejercicios de estilo ligados fundamentalmente a la parodia de los géneros, ${ }^{66}$ en el estilo andrógino, como lo señala Echavarren, hay en juego un ejercicio crítico distinto, en la medida en que se trata de un manifestación política que no solo parodia los géneros sino que está -o quiere estar- más allá de los mismos (Echavarren, 2010, 63-64). En una palabra, si en el travestismo estudiado por Butler hay en juego una suerte de fractalización de los sexos, en el estilo andrógino, tal y como lo concibo en este trabajo, está en juego la posibilidad de emplear una táctica política en la cual eliminar las diferencias sexuales equivale a eliminar la jerarquización que se sigue de ellas (véase el

${ }^{66}$ Véase por ejemplo el análisis de Butler en esta dirección ([1990] 2007, 267-275). 
apartado siguiente). Se trata, como lo sintetiza adecuadamente la teórica feminista del derecho Frances Olsen, de una diferencia entre, por un lado, la "estrategia que rechaza la jerarquización y acepta la sexualización de los dualismos (...) y, por otro, la estrategia de la 'androginia', que rechaza la propia estructura de los dualismos" (Olsen, [1990] 2013, 7). A saber: mientras que en las estrategias paródicas lo que se intenta es asumir el dualismo sexual mediante un gesto crítico que los torna risibles, el esquema andrógino busca hacer del binarismo de los sexos una realidad difusa y hasta cierto punto innecesaria.

Creo necesario insistir, sin embargo, en que no se trataría de pensar la androginia como un grado cero del poder, sino de pensar el estilo andrógino como un forma de utilización política del cuerpo en el que las diferencias de género y las jerarquías que se siguen de dichas diferencias, se revelen solubles -en el doble sentido del vocablo, es decir, en el sentido de que se tornen susceptibles de resolución y susceptibles de ser deshechas-. Precisamente en aras de conceptualizar adecuadamente ese potencial crítico del estilo andrógino, a continuación me detendré a analizar las consideraciones que Shulamith Firestone realiza en torno de las posibilidades subversivas de la androginia en tanto enclave crítico/metafísico de la diferencia sexual para, posteriormente, analizar algunas expresiones históricas de androginia a partir de dichas consideraciones.

\subsection{La dimensión política de la androginia: la ontología andrógina como enclave de la crítica}

A partir de las distinciones establecidas en el apartado anterior la androginia resulta susceptible de ser leída desde un costado político. En mi opinión, la androginia podía interpretarse, ciertamente, como un fenómeno estilístico, esto es, como un ethos corporal en el que las normas vestimentarias son puestas en entredicho mediante una estética y una ética corporal en las que tienen lugar ejercicios situados de libertad. Pero en términos de plantear la androginia como forma de estilo es necesario aclarar conceptualmente en qué sentido lo andrógino puede entenderse como una fuente o matriz ética para la crítica. 
La androginia, en tanto factor explicativo de un orden ontológico primigenio ha tenido desde siempre, según Jean Libis, dos funciones discursivas. Por un lado, explicar el origen temporal y ontológico del mundo. Pero por otro, el imaginario andrógino constituye igualmente una puesta en evidencia de que aún la más rígida concepción binaria de los sexos requiere de una justificación o explicación de su génesis -véase Libis ([1980] 2001, 254)-. El ideal andrógino, en esta medida, viene a constituir una suerte de falla -en el sentido geológico del término, es decir, en el sentido de un quiebre tectónico en el que tiene lugar una escisión- dentro de la ontología binaria de los sexos. La androginia, en efecto, apunta a poner de manifiesto que bajo la metafísica binaria de los sexos subyace un resto de caos corporal y sexual que no acaba de ser organizado de forma completamente exitosa por el discurso del dimorfismo sexual. Jean Libis señala en este sentido que la androginia

[...] nos enfrenta con una especie de escándalo ontológico (...) porque el "hombre [sic]-mujer" no es solamente el lugar de una paradoja sexual, sino también el símbolo privilegiado de la imposible yuxtaposición de los contrarios, desafío para la razón y a la vez sueño eternamente frustrado de una pacificación general, de una reabsorción de todas las oposiciones bipolares, de todas las contradicciones que gravan la condición humana (Libis, [1980] 2001, 22).

La feminista canadiense Shulamith Firestone se refiere en sus propios términos a esta problemática. Firestone, quien en su obra La dialéctica del sexo ([1973] 1976) pretende mostrar las viabilidad y necesariedad teórica y política de una revolución feminista que suprima las divisiones de clase, sexuales y etarias, señala que lo andrógino incluye un cuestionamiento metafísico al binarismo sexual, así como una interrogación política a propósito de las jerarquizaciones que se siguen a partir de dicho binarismo. Para Firestone, ciertamente, el dualismo sexual posee un carácter estratégico en la estructuración de la cultura. Según la autora, la totalidad de lo social se organiza, de hecho, con base en el dualismo sexual. En tal sentido, Firestone utiliza el ideal andrógino como ancla para una crítica de los soportes metafísicos a partir de los cuales se organiza el poder social. 
En opinión de la autora, si bien la diferencia sexual encuentra su fundamento en una cierta composición biológica, no debe confundirse lo biológico con lo humano. ${ }^{67}$ "Lo natural -apunta Firestone- no es necesariamente valor 'humano"' (Firestone, [1973] 1976, 19). En tal medida, "las diferencias genitales entre los seres humanos deberían pasar a ser culturalmente neutras" (Firestone [1973] 1976, 20). Esta apuesta por una trascendencia de lo natural - en franca afinidad, por cierto, con la crítica baudelaireana del maquillaje descrita en el capítulo anterior- implica para Firestone una destrucción con la tiranía de la familia biológica y una puesta en entredicho de la división social del trabajo. En otras palabras, a partir de su propuesta de una trascendencia metafísico/política de la diferencia sexual, la autora invierte el esquema freudiano para plantear lo andrógino no ya como un punto de partida sino como un punto de llegada, y se refiere, en tal sentido, a una "pansexualidad sin trabas -la 'perversidad polimórfica' de Freud- [que sería capaz de reemplazar] a la hetero/homo/bisexualidad" (Firestone, [1973] 1976, 20-21).

Lo andrógino, en esta medida, aparece como una especie de apertura respecto de la naturaleza y del binarismo sexual. Inscribiéndose en la tradición feminista de politización de lo personal, Firestone sostiene que la crítica de la estructura dimórfica implica una praxis transformadora de las estructuras de poder, así como la creación de una cultura política horizontal en la que las diferencias biológicas y genitales se conviertan en características ontológicamente irrelevantes. En tal sentido, si el andrógino freudiano cedía al principio de realidad mediante su adaptación a las políticas sexuales dominantes, la androginia postulada por Firestone aparece más bien ligada a una crítica de esas mismas políticas.

Dentro de la lectura firestoniana de Freud, la familia y la vida sexual adulta aparecen, de hecho, como un enmascaramiento de relaciones de poder (Firestone, [1973], 1976, 6478). En ese sentido, el ideal andrógino funciona en la teoría de Firestone a la manera de un elemento problematizador de dichas relaciones:

\footnotetext{
${ }^{67}$ Por lo demás, como lo señalan desde sus respectivas posiciones Foucault y Laqueur, la propia dimensión biológica del ser humano es de por sí inevitablemente organizada por una discursividad social que la enuncia y organiza.
} 
[...] si damos por sentado que, al nacer, el impulso sexual no se encuentra precisado ni tampoco diferenciado del conjunto de la personalidad (la "perversidad polimórfica" de Freud); si, como hemos visto, solo se diferencia en respuesta al tabú del incesto; si, además, este tabú tan solo es necesario para la preservación de la familia, resultará que, en el caso de que eliminemos a esta última, destruiremos también todas las rerpresiones que conducen a la sexualidad hacia realizaciones específicas" ([1973] 1976, 77-78).

Lo andrógino, dentro de este esquema, reaparece entonces no ya como una condición más o menos vinculada a la cuestión fisiológica como en la teoría de Freud, sino como una fuente crítica del ordenamiento social sexuado y de sus concomitantes instituciones y relaciones de poder (la autora piensa especialmente en la familia y en la reproducción social de jerarquías sexuadas con base en el cuido de los niños y la tenencia de la propiedad). En tal sentido, Firestone hace énfasis en cómo una crítica al género binario podría llegar a generar una crisis total de la cultura. Al no contentarse con eliminar los privilegios masculinos y aspirar a cuestionar el propio eje a partir del cual se engendran dichos privilegios, una transformación de estas características debilitaría, en opinión de Firestone, zonas neurálgicas del orden social que dependen de dicho eje, como por ejemplo las políticas de reproducción, el poder en la familia, la cuestión del cuidado de los niños, enfermos y ancianos y, en suma, lo que podríamos llamar a partir de Foucault el núcleo duro del bipoder. La crítica andrógina, tal y como la esboza Firestone, pasa entonces por un cuestionamiento de la organización social y del poder ejercido sobre los cuerpos con base en las marcas de género.

Es interesante, por otra parte, el hecho de que Firestone preste atención en diversas instancias de su obra anteriormente citada al tema del aspecto y la presentación corporal. Aún cuando Firestone otorga, como señalaré en al apartado final de este capítulo, una relevancia especial al tema de la ciencia y de la posibilidad que esta ofrece de trascender la naturaleza, la autora alude igualmente al modo en que los ideales de belleza y la uniformización de la apariencia contribuyen a generar prácticas jerarquizantes en relación con los cuerpos (véanse las críticas feministas referidas a este asunto en el capítulo anterior). Así, dado que la uniformación en la vestimenta femenina redunda en un mayor control de los cuerpos de las mujeres (Firestone, [1973] 1976, 77-78), el ideal andrógino 
podría leerse igualmente vinculado en el pensamiento de Firestone con un borramiento de las marcas de género -la autora, por lo demás, establece un vínculo similar entre aspecto y dominación corporal cuando analiza el papel de la vestimenta en la desigualdad etaria; véase Firestone ([1973] 1976, 101-103)-. En todo caso, resulta claro que para Firestone la posibilidad de una crítica andrógina no está exenta de cierto revestimiento estético, toda vez que según la autora el ideal andrógino involucra precisamente una combinatoria de elementos tecnológicos -esto es, críticos de la naturaleza y la biología- con elementos propios de la "modalidad estética" -es decir, aquella que se dirige a la "búsqueda de lo ideal, realizada con un medio artificial" (Firestone, [1973] 1976, 219)-. Firerstone, en tal medida, se refiere a lo andrógino en vinculación con la necesidad de crear "estilos de vida" allende el binarismo ([1973] 1976, 284-301), a saber: la androginia, dentro de su esquema, es capaz de asumir una cierta presencia cultural no excenta de características estéticas.

Un cuestionamiento andrógino del binarismo, así, apuntaría no únicamente a revocar críticamente el dualismo sexual, sino también las líneas transversales que atraviezan las distintas formas de poder tal y como estas se instituyen a partir de la gestión estetizada de la diferencia sexual. De esta manera, según lo apunta Firestone a tono con la época en la cual se produjo su libro,

[...] la próxima revolución cultural nos traerá la reintegración del varón (...) con la hembra (...), a fin de crear una cultura andrógina que se remonte por encima de ambas corrientes e incluso por encima de la suma de sus integraciones. Más que una unión, deberá ser una abolición de las propias categorías culturales, una cancelación mutua -una explosión de la materia con la antimateria, que finalice con el estallido de la cultura misma (Firestone, [1973] 1976, 238).

No obstante, queda todavía por descifrar de qué manera estas críticas andróginas podrían desembocar en praxis estilísticas ligadas directamente con la indumentaria y con un uso contrahegemónico de las prendas. En tal sentido, resulta necesario pasar revista por las distintas apropiaciones andróginas de la vestimenta a lo largo de la historia, de modo que sea posible no solo detectar cómo la crítica andrógina se despliega por fuera de los discursos, sino también cartografiar un porvenir para el estilo andrógino. 


\subsection{En busca de un linaje: elementos para el rastreo histórico del estilo andrógino}

Así como la androginia mítica ha sido fuente de diversas versiones justificatorias del binarismo de género, el estilo andrógino se podría caracterizar, por otra parte, por su adopción de una pluralidad de formas que cuestionan ese mismo binarismo. Dentro de este tipo de aproximación, como ya he señalado, lo andrógino se despega de lo anatómico, en el sentido de que remite a una estilización politizada del cuerpo, y en la medida en que involucra antes una manera de conducirse que una constitución biológica dada. En este último sentido, lo andrógino aparece ligado a un tipo de trabajo sobre el cuerpo capaz de cuestionar el núcleo dicotómico de género a partir del cual tienen lugar las prácticas de disciplinamiento corporal propias de la moda. Lo andrógino, conceptualizado en tanto estilo vestimentario, designa entonces un modo de ataviarse y de lucir el cuerpo cuyo rasgo constitutivo viene dado por la ambigüedad respecto de las roles sexuales tal y como estas se conceptualizan a partir del binarismo de género.

Roberto Echavarren considera que el estilo andrógino surge, en tal medida, como resultado de la muerte de Dios y del sujeto. De forma sentenciosa, Echavarren considera que "hoy podría aventurarse [que] el hombre [sic] y la mujer han muerto" (Echavarren, 2010, 53). Para el crítico uruguayo, el andrógino debería leerse, en efecto, a través del prisma nietzscheano/foucaultiano de la muerte de las esencias. En este sentido, Echavarren señala que así como se ha declarado la defunción del sujeto en tanto constructo ideal que soporta una serie de creencias y consabidos metafísicos, tendría que declararse igualmente la muerte de los géneros, en tanto paradigmas ontológicos a partir de los cuales se despliegan técnicas de poder sobre los cuerpos. Asimismo, la homosexualidad, en tanto identidad esencializada tendría que someterse a una interrogación crítica:

[...] el homosexual ha durado cien años. El hombre, como su heredero de un Dios muerto, ha vivido un período equivalente. Su norma, sus desviaciones y sus patologías, es lo que las ciencias humanas han procurado construir en poco más de un siglo. El homosexual, como patología del hombre, y el hombre como canon, 
naturaleza, identidad, se revelan como dos nociones provisorias y simétricas. Su carrera resulta homóloga. Se disuelven juntas (Echavarren, 2010, 64).

El exacto reverso de esa disolución no es para Echavarren otra cosa que el andrógino. La androginia estilizada es, por tanto, según este autor, una manifestación cultural en la que el cuerpo se construye como una suerte de artificio que pone en evidencia los límites vacilantes de las esencias masculina y femenina, así como también las esencias heterosexual y homosexual. Si la androginia, en su registro mítico, aparece como fundamento de la dicotomía sexual y como matriz a partir de la cual se engendran unos géneros metafísicamente heterogéneos e irreductibles el uno para con el otro, los ejercicios de estilo andróginos, por otra parte, objetan esa matriz dicotómica haciéndola vacilar y mostrándola en toda su ambigüedad y vaguedad ontológica. De este modo, lo que a tono con el capítulo 5 del presente trabajo podría denominarse la androginia ética designa, frente a la androginia mítica, una posibilidad estilística que desafía las gramáticas corporales hegemónicas, antes que un mero constructo simbólico. Tal y como lo señala Echavarren, lo andrógino, entonces, “en lo que tiene que ver con el estilo, nunca es un objeto en sí, sino más bien un campo de permutaciones irreverentes” $(2010,50)$.

En mi opinión, la androginia tiene que ver, pues, más con un cierto uso de la ambigüedad indumentaria que con una estética corporal en la que prive la intercambiabilidad de los sexos. En otras palabras, la androginia no busca equiparar la masculinidad y la feminidad, sino mostrar la contingencia de esos dos polos en tanto mecanismos de subjetivación. Laqueur se refiere en este sentido a la posibilidad abierta por Foucault de pensar en un trabajo de sí que no se refiera a ninguno de los géneros, sino simplemente a lo humano (Lauquer, [1990] 1994, 37). ${ }^{68}$ La crítica del andrógino consiste, en tal sentido, en reclamar el estatuto de sujeto al tiempo que se rechaza una de las características supuestamente constitutivas de la subjetividad, es decir, la pertenencia exclusiva a uno solo de los sexo-géneros.

\footnotetext{
${ }^{68}$ Sobre este punto véase asimismo el análisis del historiador y teórico literario David Halperlin en su libro San Foucault (Halperlin, [1995] 2007, 110-113).
} 
Según mi lectura de Firestone, el estilo andrógino parte, así, de la dicotomía sexual y las instituciones que le son concomitantes como formaciones histórica y ontológicamente contingentes. Dentro de mi perspectiva, sin embargo, ello ocurre no ya en busca de una unidad venidera, sino de abrir históricamente la posibilidad de morfologías allende el género. Mientras que el mito andrógino, por tanto, tiene en el monismo sexual su punto de partida y en el dualismo sexual su punto de llegada, podría decirse que el estilo andrógino lleva a cabo una inversión de dicho esquema partiendo del dualismo sexual como hecho cultural y promulgando su necesaria destrucción ontológica por efecto de un progresivo evaporamiento que no lleva, en sentido estricto, a una unidad, sino a la crítica de las jerarquías. Partiendo de Firestone y Echavarren, considero, por lo tanto, que al combinar críticamente en el propio cuerpo lo femenino y lo masculino, el estilo andrógino disuelve hasta tal punto la especificidad de cada género que podría acabar perturbando el núcleo binario sexual mismo en tanto basamento de la estructuración social, y por lo tanto, la eficacia y legitimidad que dicho núcleo confiere a una serie de instituciones y prácticas culturales.

No obstante, hasta nuestro presente histórico los ejercicios de estilo andrógino, contrariamente a lo ocurrido con el dandismo o el feminismo, parecieran ser más bien manifestaciones aisladas o "brotes" que expresiones de un movimiento cultural. El dandismo, por ejemplo, con todo y el culto a la singularidad que le es propio, alcanzó sin embargo a dibujar un núcleo cultural que lo contiene; el feminismo, por su parte, no solo constituye ya de por sí un movimiento social, sino que también es una de las más poderosas y sugestivas corrientes críticas de la modernidad. La androginia, en cambio, carece hasta el presente de programa; su agenda política, en cierto sentido, se encuentra todavía en ciernes. Creo impropio, en esta línea, hablar de la androginia como un estilo propiamente dicho. Considero, por el contrario, que se trata más bien de una tentativa estilística -o de un conjunto de brotes de estilo-, no obstante promisoria. Quisiera, pues, en el próximo apartado, trazar un provisorio linaje andrógino entendido este en términos de estilo. A saber: quisiera cartografiar tentativamente lo que podría denominarse los brotes histórico/filosóficos del estilo andrógino o las manifestaciones a partir de las cuales podría concebirse, teóricamente hablando, un porvenir para el estilo andrógino. 


\subsection{Los distintos estadios de un estilo profano: algunos brotes de estilo andrógino}

En mi opinión, los primeros brotes de estilo andrógino podrían ubicarse, siguiendo a Jean Libis, a partir de vetustos usos rituales de las prendas en las cuales se buscaba confundir y mezclar los géneros. ${ }^{69}$ Libis habla de rituales de este tipo en la Antigüedad clásica y señala que en ellos se estilaba el cambio y la mixtura de ropas femeninas y masculinas, como parte de una "articulación mito/rito" (Libis, [1980] 2001, 109). A través de referencias vinculadas a trabajos etnográficos y de historia de la religión, el autor francés hace alusión a prácticas de diversas culturas en las que se establecían combinatorias indumentarias para evocar supuestas cualidades bisexuales de dioses andróginos. En esta línea, Libis se refiere también a rituales de paso en los cuales tenían lugar expresiones andróginas en momentos de tránsito de una etapa hacia otra-como por ejemplo la mezcla de vestidos masculinos y femeninos en ocasión del pasaje de la vida infantil a la vida adulta, o el afeite de la cabeza en las mujeres y la implementación de vestidos masculinos en varones durante las ceremonias matrimoniales (Libis, [1980] 2001, 108-113)-. Se trata más bien de androginias episódicas, usualmente relacionadas con elementos taumatúrgicos y socialmente organizadas como instancias específicas fuera de las cuales lo andrógino se veía penalizado. Según Libis, en estos casos "la práctica ritualizada del disfraz intersexual, cargada de connotaciones andróginas, está inscrita en una serie de procesos de tipo mágico" en las que habría en juego no únicamente un tipo de "identificación totémica" sino también "una especie de disolución simbólica del principio de individuación" ([1980] 2001, 109). Aún así, es esta todavía una especie de prehistoria del estilo andrógino, en la medida en que lo que está en juego es una protoandroginia, si bien hasta cierto punto transgresora, debidamente codificada por el rito y la referencia mítica y confundida todavía con la bisexualidad y el travestismo.

\footnotetext{
${ }^{69}$ Me restrinjo acá, debido a la naturaleza temática de mi investigación, a expresiones estilísticas referidas al cuerpo, aunque, como es sabido, el mundo del arte ha explotado la figura del andrógino desde épocas remotas. Un recorrido medianamente pormenorizado de los derroteros de la androginia en la historia del arte europeo -aunque se trata de un recorrido que parte de ciertos supuestos metafísicos sobre el sexo cuestionables según la perspectiva que he utilizado en el presente trabajo-, puede verse en Paglia ([1994] 2006).
} 
Existe, asimismo, documentación referida a épocas posteriores con cierto grado de distensión respecto de las normativas vestimentarias. En ellas habrían tenido lugar una cierta circulación de prendas y elementos de ornato de ambos sexos en individuos que se encargarían de combinar las mismas con cierto nivel de autonomía: mujeres enfiladas en el ejército, varones afeminados, personas que transitan de un sexo a otro. Ciertamente no se trata aún de una androginia propiamente dicha dado que en este tipo de fenómenos pesa aún la eficacia del poder vestimentario. De todas maneras podemos ubicar aquí casos como los referidos por Foucault ([1980] 2007), Laqueur ([1990] 1994, 234-236) y Bard ([2010] 2012, 68) en los que, con distintos niveles de tolerancia, se abre el paso a utilizaciones andróginas de las prendas. Se trata, insisto, de episodios en los que lo andrógino, si bien ya no se confunde con el mito, tiende a mezclarse con prácticas de travestismo - en las que persiste la polaridad de los géneros- y a estar aún plegada a políticas regulatorias de la anatomía. Por lo demás, existe toda una codificación con respecto a los usos de esas prendas y a los umbrales respecto de lo permitido y lo prohibido. En sentido estricto, por lo tanto, tampoco se trata de expresiones estilísticas andróginas propiamente dichas, sino de episodios que conforman una suerte de prehistoria del estilo andrógino.

En cambio, un tercer momento de la estirpe andrógina, ahora sí fundacional, se da de la mano de la implementación de lo unisex. La irrupción de lo unisex, por el contexto político en el que se gesta y por el ligamen con la muerte de los géneros que involucra, puede ciertamente considerarse, en contraste con los episodios anteriormente comentados, como un primer hito histórico de la androginia. Surgido en el contexto de las luchas contraculturales y sociales de los $60-\mathrm{y}$ en gran medida como resultado de los ejercicios críticos de estilo analizados en el capítulo anterior- lo unisex surge, en efecto, como una expresión del ideal andrógino cuyo valor como tendencia vestimentaria fue fundamental en la medida en que abrió la posibilidad de encarnar los géneros de manera menos rígida o acartonada. Como lo señalan los especialistas en moda Marie-Thèsése Basse y Olivier Burgelin, lo unisex "marca una ruptura simbólica, una nueva era en el vestir en la que (...) el dimorfismo sexual en la ropa aparece como una posibilidad, no como una estricta obligación" (citado en Bard, [2010] 2012, 253-264). En otras palabras, 
lo unisex constituye una especie de momento fundacional del estilo andrógino, toda vez que surge de un contexto sociopolítico en el que los polos del dimorfismo sexual comenzaban a ponerse en entredicho. Lo unisex quiere, en efecto, no solo reducir la brecha entre los sexos sino también mostrar el propio hecho de que dicha brecha es sociohistóricamente movediza.

Sin embargo, lo unisex constituye más una de las posibilidades de lo andrógino que su versión definitiva. De hecho, lo unisex aparece antes como un fenómeno de diseño de modas que suscita adscripciones que como la manifestación de una ética en el sentido foucaultiano. En este sentido, si bien lo unisex es, por derecho propio, uno de los aspectos emergentes andróginos con mayor visibilidad histórica, en rigor habría que señalar que dicha tendencia está lejos de desplegar todas las aristas de la crítica andrógina. En efecto, tomando en cuenta que lo unisex aparece en un primer momento de debilitamiento de la hegemonía del binarismo de género, más vale pensar en lo unisex como una primera manifestación de androginia que como su expresión más acabada. De hecho, puede proporcionarse un elemento diferenciador entre ambas matrices: mientras lo unisex designa un tipo de indumentaria que puede ser usada indiferentemente por cuerpos clasificados como varoniles o femeninos manteniendo no obstante la diferencia entre ambos polos, lo andrógino, en su veta más bien utópica, cuestiona el propio núcleo diferenciador de lo varonil y lo femenino. La androginia es capaz de alteraciones sumamente abarcativas (en cuenta la mezcla imprevisible, la reconfiguración, la disolución, la confrontación, y la hibridación de elementos masculinos y femeninos); lo unisex, en cambio, se centra sobre todo en potabilizar algunos rasgos vestimentarios comunes de los sexos para integrarlos en un todo estetizado y susceptible de mercantilización.

Lo camp, en cambio, podría interpretarse como una radicalización de la androginia propia de las tendencias unisex. En un sentido general, la sensibilidad camp designa desde el célebre ensayo de la escritora estadounidense Susan Sontag dedicado a la temática, "aquella que está abierta a un doble sentido en que las cosas pueden ser tomadas" (Sontag, [2007] 2012, 358). A partir de esta conceptualización sobre lo camp, Sontag 
ofrece, en efecto, algunos elementos a partir de los cuales es posible pensar en el estilo andrógino como una forma de crítica corporal ligada a la indumentaria. Si bien para Sontag lo camp no es reductible a lo andrógino -ni viceversa-, existen ciertas zonas donde ambas derivas estilísticas se traslapan. Así, mientras que el camp hace referencia a una amplia gama de objetos, tendencias artísticas, obras de arte y maneras de ser y comportarse caracterizadas por la ambigüedad, lo andrógino refiere a la ambigüedad específicamente sexual tal y como se despliega socialmente a través de los cuerpos estilizados. Para Sontag, en esta medida, “el andrógino es ciertamente una de las mejores imágenes de la sensibilidad camp" (Sontag, [2007] 2012, 356), aunque dicha sensibilidad ciertamente exceda lo propiamente corporal.

Lo camp, en su dimensión andrógina, esto es, en su dimensión propiamente corporal, refiere entonces según Sontag a un doble sentido y a un uso crítico de la ambigüedad. El estilo andrógino es para esta autora una forma de hacer prevalecer la indeterminación y lo confuso mediante una estética impresa sobre el propio cuerpo. La figura del andrógino, en efecto, aparece relacionada en opinión de Sontag con la ambigüedad sexual y el artificio. Esta dimensión artificial atribuida por Sontag a lo andrógino resulta fundamental en el contexto de un análisis estilístico toda vez que permite remitir dicho concepto a una serie de operaciones éticas llevadas a cabo con y sobre el propio cuerpo. La vinculación llevada a cabo por Sontag entre la androginia y la artificialidad permite, así, sustraer a aquella definitivamente del ámbito de lo mítico y de lo anatómico para hacerla ingresar en un terreno ético y político. En este sentido, si pensamos la androginia como manifestación estilística ligada al artificio y no ya como condición biológica, la prenda aparece como un insumo técnico capaz de dotar al cuerpo de unas inusitadas formas que, si bien parten de los convencionalismos de género, tantean una combinatoria de los mismos que quiere trascenderlos.

No obstante, como lo señala el crítico y teórico literario José Amícola, lo camp posee una significación estética y política no siempre advertida en toda su profundidad por Susan Sontag. A partir de su sugerente relectura de Sontag, Amícola señala en este sentido que lo camp, en lo que tiene que ver con lo andrógino, se revela como una gestualidad 
teatralizante que ironiza respecto de las esencias de género pero también respecto de su polarización. Para Amícola, en efecto, una de las dimensiones del camp es su resignificación de las oposiciones de género. En otras palabras, el camp constituye para este autor un ejercicio de apropiación estilística abiertamente inscrita en el contexto de los esfuerzos por volver anacrónicos los géneros: "el camp [señala Amícola interpretando a Jameson] da (...) entidad a la más delirante de las integraciones al mercado, imponiéndole a éste sus propios términos de juego" $(2000,47)$. En tal sentido, "una de las características del camp [es] el gusto por el ser impropio de las cosas y por lo andrógino" (Amícola, 2000, 66). Según Amícola el camp "implica [además] una fuerte ironía autorial, por donde se manifiesta con mayor fuerza el lugar desde donde se emite la enunciación" (Amícola, 2000, 50). En términos de mi conceptualización de estilo del capítulo 5, este elemento del camp resulta de suyo relevante pues, contrariamente a lo unisex, la androginia camp resalta un rasgo constitutivo del estilo, a saber, su dimensión aletúrgica. A partir del esquema de Amícola, ciertamente, todo el circuito de comunicación emisor-mensaje-receptor se ve alterado: lo camp reclama para sí una reconfiguración de los contratos de lectura a partir de los cuales se percibe el cuerpo generizado. El camp, así, varía los códigos de recepción y las propias lógicas enunciativas, en la medida en que, a la manera del ethos crítico descrito por Foucault, el andrógino camp toma la palabra, en lugar de esperar por ella.

Para Amícola, por otra parte, la androginia-pastiche de la estética camp re-visita el cuerpo femenino para alterar sus atributos y volver irrisoria la idealización fantasmática de lo femenino que se lleva a cabo a partir del binarismo heterocéntrico. La androginia camp, en esta medida, constituye una suerte de mascarada que juega a evidenciar el carácter arbitrario de las identidades y la posibilidad de una subjetividad que ya no sea, sino que se atreva a devenir (Amícola, 2000, 84). Amícola cree así que la androginia camp, puede irradiar su crítica por fuera de los circuitos discursivos de los cuales emerge -a saber, los movimientos gays posesentistas- para convertirse en:

un emblema de lucha de los cambios en la concepción de la sexualidad, en tanto lo que parece ahora evidente es que el poder se ha apoyado en la separación neta 
de los dos sexos biológicos con la intención de imponer al uno sobre el otro (Amícola, 2000, 86).

Echavarren, por otra parte, plantea un último grupo de brotes andróginos. Se trata de expresiones contemporáneas ligadas a la música y al mundo de las subculturas. En esta línea, Echavarren explora los elementos andróginos de figuras del espectáculo como Prince y Michael Jackson, entre otros. Se trata de expresiones andróginas con un talante abiertamente espectacular y en franca sintonía con el despliegue de la cultura de la imagen propia de nuestros días. Dada su conceptualización del estilo como un ejercicio de disenso singular que pone el acento en un acoso de la ley universal, Echavarren se refiere a estos brotes mediáticos de androginia, de hecho, en términos de estilos heroicos (Echavarren, 2010, 96). En suma: Echavarren lee el cuerpo del rock como un cuerpo andrógino. No obstante, a sabiendas de que se trata de formas de estilo más bien localizadas, el autor también presta atención a algunos colectivos contemporáneos en los que se encuentran latentes ciertos elementos andróginos. En particular, Echavarren hace referencia a cierta desnaturalización del aspecto presente en la contracultura punk -en contraste con el naturalismo hippie- así como a algunas expresiones recientes tales como el emo. ${ }^{70}$ Echavarren, así, estudia estos fenómenos dando cuenta de la influencia de la estética andrógina dentro de los nuevos circuitos de circulación mediática, haciendo énfasis en el modo en que una nueva iconografía andrógina ha ganado terreno cultural a partir de ellos.

Como se ve, el caso de la androginia se diferencia de los estilos vestimentarios estudiados en el capítulo anterior en virtud de su talante menos constituido o acaso más incipiente. De ahí que he preferido referirme a las manifestaciones andróginas aludidas en este apartado en términos de brotes estilísticos en lugar de referirme a la androginia como un estilo propiamente dicho. Sin embargo, dada la dependencia histórica del estilo andrógino con respecto a ciertas coyunturas sociales y políticas vinculadas a las críticas de género llevadas a cabo a partir de la segunda mitad del siglo pasado, considero que vale la analizar, para terminar, las posibilidades futuras del estilo andrógino. Especialmente me

\footnotetext{
${ }^{70} \mathrm{El}$ autor define lo emo como un tipo de estética corporal, ligada a un género musical derivado del punk y surgido a mediados de los años ochenta, en la que aparece una cierta actitud y unos cuantos patrones estéticos ligados con la desexualización del aspecto (Echavarren, 2010, 111-118).
} 
refiero a la posibilidad de vincular la androginia con algunas configuraciones actuales asociadas a los cambios tecnológicos y su impacto en los cuerpos.

\subsection{A manera de epílogo: las nuevas posibilidades del estilo andrógino}

En opinión de Walter Benjamin, la moda "está en conflicto con lo orgánico", es decir: la moda "acopla el cuerpo vivo al mundo inorgánico" ([1974] 21012). Pero mientras Benjamin veía en dicho fenómeno una expresión de cierto fetichismo mercantil y un culto perverso hacia lo no-vivo, en estos últimos capítulos he querido pensar un uso estilístico de la indumentaria que emplee esa tensión entre la prenda y la naturaleza (tensión, caber recordarlo, de carácter estrictamente analítico pues, como indiqué en el segundo capítulo, la prenda y el cuerpo conforman una unidad fenomenológica) de una forma productiva en términos críticos.

Si pensar en lo humano como un significante abierto provee el marco teórico necesario para dibujar nuevas formas de libertad, -tal y como lo sugirió Foucault en Las palabras y las cosas a través de la imagen de la muerte del sujeto ([1966] 2002,398)- la posibilidad de emplear lo inorgánico para disolver las fronteras de lo humano aparece como una operación deseable dentro del contexto de las críticas corporales que he venido esbozando. A la vez, permite subrayar la distancia entre la androginia, considerada como estilo, de la condición anatómica del hermafrodita y su raigambre biologicista. En el caso andrógino, el suplemento técnico aparece, de hecho, como un insumo ético que permite precisamente transformar el aspecto del cuerpo en aras de borrar las marcas del dualismo de género, así como de modificar otros rasgos igualmente explicados en términos biológicos. La noción de técnica tal y como la he venido empleando hasta ahora -es decir como un tipo de acción ética que comprende el atavío y que se encuentra destinada al trabajo de uno sobre sí mismo- tiene un cierto parentesco, en este sentido ,con la noción de tecnología tal y como se entiende dicho concepto a partir de Galileo. Foucault, de hecho, considera que ambas formas de técnica, las que se dirigen hacia uno mismo y las que permiten la producción y manipulación de cosas, constituyen -junto a las técnicas de 
producción de signos y las técnicas de poder- formas de la razón práctica. En otras palabras, partiendo de Foucault, es posible afirmar la distinción entre técnica de sí y tecnología, asumiendo simultáneamente la existencia de una zona común entre ambas ([1988] 2008, 48). En el caso de lo andrógino, este esquema permite indagar acerca de las posibilidades de pensar ejercicios de estilo que integren dentro de los procedimientos de acicalamiento y atavío las tecnologías desarrolladas por la ciencia.

Diversas reflexiones tienden, de hecho, a converger a propósito de las posibilidades que los distintos desarrollos tecnocientíficos ofrecen al estilo andrógino. Shulamith Firestone, por ejemplo, subraya la centralidad de la tecnología en el marco de la creación de una cultura andrógina. Para Firestone, como lo señalé supra, lo andrógino aparece fundamentalmente emparentado con la tecnología en el sentido de que esta última representa una vía no solo para trascender vetustas jerarquías consolidadas debido a su raigambre "natural" -aunque, como he argumentado en distintas instancias de este trabajo, dicha naturaleza no existe por fuera de una discursividad social que la enuncia y administra-, sino también como un medio para trascender la propia concepción de humanidad tal y como esta se ha desarrollado en el marco del despliegue del capitalismo patriarcal occidental. Según Firestone, los insumos provistos por la ciencia moderna son capaces, en la medida en que alteran los procesos reproductivos y los ciclos biológicos mismos, de posibilitar una cultura andrógina en la cual la totalidad de lo viviente podría llegar a organizarse sin tener en cuenta la diferencia de género.

Pero Firestone deja de lado el problema de cómo podrían llegar a participar los cuerpos concretos en una transformación de esas características. En su análisis sobre la figura del cyborg, en cambio, Donna Haraway subraya la centralidad estratégica del cuerpo dentro de los nuevos órdenes establecidos por los desarrollos tecnocientíficos. Haraway define al cyborg como "un organismo cibernético, un híbrido de máquina y organismo, una criatura de realidad social y también de ficción" (Haraway, [1991] 2995, 254). En esta línea, la autora plantea el cuerpo cyborg, de hecho, como "una criatura en un mundo posgenérico" ([1991] 1995, 255) y ve en la corporalidad andrógina del cyborg una capaz de "restaura[r] algo del hermoso barroquismo reproductor de los helechos invertebrados 
(magníficos profilácticos contra la heterosexualidad)" ([1991] 1995, 254). Haraway, retomando críticamente el feminismo que Firestone contribuyó a delinear, propone así al cyborg "como un esfuerzo por contribuir a la cultura y a la teoría feminista socialista de una manera posmoderna, no naturalista, y dentro de la tradición utópica de imaginar un mundo sin géneros" ([1991] 1995, 254) ${ }^{71}$ Contrariamente a Firestone, Haraway sostiene que una revuelta andrógina como la del cyborg no encaminaría la cultura al reestablecimiento de una unidad perdida a la manera de una "simbiosis preedípica" ([1991] 1995, 254), sino que por el contrario se trataría de una revuelta en la que los cuerpos romperían con la propia idea de un origen para afirmar su carácter irreductiblemente sociohistórico. Se trataría de un acabamiento de lo humano, si por humano entendemos restrictivamente, como lo hacen a menudo los discursos hegemónicos, aquellos organismos susceptibles de ser clasificados como pertenecientes a uno de los dos "sexos verdaderos" - como los llama irónicamente Foucault ([1980] 2007)-. El cyborg, en tanto posibilidad utópica del cuerpo andrógino, aparece por lo tanto como una posibilidad de trascender la biología mediante el estilo y como un tipo de cuerpo que, al integrar la tecnología en el corazón de lo viviente, acaba con la frontera de los sexos, así como con la dicotomía naturaleza/cultura.

Echavarren, por su parte, habla también del estilo andrógino como uno en el cual priva una experiencia "posnatural" del cuerpo; en tal sentido, dicho autor se refiere al estilo andrógino como una forma de corporalidad mutante $(2010,64)$. Lo andrógino, para Echavarren, constituye una forma de estilizar los cuerpos allende los géneros $\mathrm{y}$, por lo tanto, la androginia involucra, también para este autor, la posibilidad de llevar el cuerpo más allá de sus confines -o al menos de aquellos confines que trazan en nuestra cultura el umbral de lo humano-. Según Echavarren, en tal sentido, a partir de la muerte del hombre y la mujer lo que emerge es la figura del andrógino-mutante: el estilo andrógino, así, se presenta como un tipo de ethos corporal que trasciende los géneros y que busca relativizar el sexo en tanto elemento sine qua non de la condición humana. La dimensión

\footnotetext{
${ }^{71}$ Cabe señalar, al menos brevemente, que no hay contradicción alguna -como podría pensar algún lector desprevenido- entre afirmar una postura feminista y promulgar simultáneamente la deseabilidad de un mundo sin géneros. Dicho mundo, de hecho, solo podría construirse desde una perspectiva feminista toda vez que el binarismo de género se sostiene sobre la base de su necesariedad para el funcionamiento de las lógicas patriarcales.
} 
mutante del andrógino, por tanto, viene dada por esa característica suya de apelar a lo tecnológico en el marco de una búsqueda de trascendencia de la biología.

Lo que intento mostrar a partir de esta relación entre androginia y tecnología, finalmente, es que los cuerpos, particularmente en el contexto sociopolítico actual, podrían contribuir a borrar la frontera entre los géneros al tiempo que se diluye la frontera entre lo artificial y la naturaleza. En la actual época, dominada por lo cibernético, lo andrógino representa, por ende, no solo la posibilidad de un acabamiento de lo natural -entendido como reducto culturalmente virgen- sino también del fin de los géneros -entendidos precisamente como naturaleza dicotómica y jerarquizante-. Siguiendo a los autores mencionados, en efecto, la hibridación del cuerpo con la tecnología podría llegar a producir un quiebre definitivo con la idea de un cuerpo natural, y por lo tanto, con el concepto del humano sexuado. En última instancia, lo que el estilo andrógino postularía dentro de esta veta, hasta cierto punto utópica, es un cuestionamiento radical con respecto a las exclusiones puestas en marcha por el concepto de "lo" humano. Si el cuerpo humano, como ya he señalado, no siempre resulta reconocible dentro de los parámetros de inteligibilidad sociales, entonces los ejercicios de estilo andróginos constituyen formas de cuestionamiento corporal a las coordenadas ontológicas que rigen lo que resulta legible como cuerpo. Desde esta perspectiva, la androginia podría utilizar la superficie del organismo como instancia crítica "posnatural” crítica de los esencialismos biologicistas. Se trataría de aprovechar una coyuntura en la que, como lo apunta Vigarello priva "la idea de un cuerpo susceptible de transformaciones infinitas" ([1999] 2006, 437).

Dado que el andrógino se encuentra en una posición liminar, podría pensarse, entonces, que el estilo andrógino funciona a la manera de una prevención contra los cierres del significante humano. Si la androginia se caracteriza por la adopción de perfiles estilísticos cambiantes (y no por la promulgación de un tercer género a la manera de una integración de lo femenino en lo masculino) que, sin embargo, poseen el denominador común de escapar a un núcleo antropológico instituyente como lo es el binarismo de género, cabe pensar en el estilo andrógino como una suerte de ethos no esencialista. Así, pues, quisiera concluir señalando que la advertencia andrógina en contra de las 
exclusiones esencialistas podría llegar a articularse a la manera de una ética (siempre en un sentido foucaultiano y no en el sentido restringido de una mera adhesión a unos códigos morales previamente definidos). Retomando la concepción del cuerpo andrógino como un cuerpo allende los géneros y la naturaleza, la androginia aparece entonces como una forma de estilo vestimentario/tecnológico que anuncia un cierto porvenir. El tecnorganismo andrógino construye performativamente un cuerpo que hace vacilar la idea de un origen, así como de un destino derivado de ese origen. El estilo andrógino, pues, es capaz de interrogar las taxonomías binarias y naturalistas en la misma medida que es capaz de evitar las reificaciones mediante la crítica corporal. En otras palabras, se trataría de pensar lo andrógino como un estilo corporal que postula la posibilidad ontológica de una existencia allende el género.

En lo tocante a la relación entre tecnología y técnica vestimentaria la androginia aparece, pues, como una deriva estilística capaz de generar una serie de recodificaciones a partir de las cuales el cuerpo podría llegar a resistir múltiples sintaxis sin por ello ser descartado ontológicamente como un no-cuerpo. Sin embargo, no se trataría, en mi opinión, de pensar la androginia como un modelo de subversión, sino de ver en la opción andrógina una estrategia ética que, en la medida en que indaga por los supuestos antropológicos que rigen la vida corporal, es capaz de presentar nuevas formas de pensar esa misma vida corporal. Si como lo señala Foucault, la ética no se limita al acatamiento de una serie de prescripciones de conducta sino que abarca también una ascética, el cuerpo vestido del andrógino se presenta como un cuerpo crítico que interroga no solo los supuestos dicotómicos de la antropología filosófica dominante, sino también varios de los supuestos de las filosofías de la moda estudiados al inicio del presente trabajo.

Sin embargo, no debe olvidarse que el estilo andrógino, como todo estilo, obtiene su eficacia última no solo en la medida de su capacidad de inventiva, sino en virtud de que es motorizado por una necesidad de reconocimiento. En tal sentido, como lo apunta Butler, cabe recordar que 
si nuevos modos de subjetividad pueden ser posibles [a partir de la irrupción de nuevos tipos de cuerpos], ello no se deduce del hecho de que haya individuos con capacidades especialmente creativas. Tales modos de subjetividad se generan cuando las condiciones limitantes de que estamos conformados demuestran ser maleables y reproducibles, y cuando cierto yo arriesga su inteligibilidad y su reconocibilidad en un envite por exponer y explicar las maneras inhumanas en que "lo humano" sigue haciéndose y deshaciéndose (Butler, [2005] 2009, 180).

El cuerpo estilizado del andrógino, pues, constituye una expresión de los límites de nuestros parámetros sociales para reconocer las diversas expresiones de "lo" humano: la radical eticidad de sus contornos, en efecto, ensancha los límites de lo que consideramos posible. 


\section{Conclusiones}

He comenzado refiriéndome a la moda y he terminado discurriendo sobre las posibilidades del cuerpo. El itinerario recorrido, más allá de sus finalidades expositivas, resulta indicativo: hablar sobre la moda es ya estar hablando sobre el cuerpo, así como también es cierto lo inverso. En efecto, si prenda y cuerpo, tal y como lo advierte Merleau-Ponty, conforman una unidad fenomenológica, pareciera imperativo, a la hora de abordar el problema del vestido, reflexionar en torno de lo corporal.

No obstante, como lo mostré en la primera parte de este trabajo, dichos análisis sobre el cuerpo no siempre encuentran su lugar al interior de los discursos teóricos sobre la moda. De hecho, tal y como argumenté en el capítulo 1, la mayoría de estudios sobre moda se centran en el problema de la difusión y de la imitación, desplegando así una serie de supuestos en relación con la dimensión propiamente corporal involucrada en el empleo de la indumentaria. Este proceder metodológico, el cual he presentado siguiendo a Foucault en términos de la conformación de una episteme en torno de la moda, se encuentra presente en análisis variopintos e inclusive aparentemente opuestos. Así, tanto en análisis sociológicos, como en esquemas semiológicos y psicológicos, alrededor de la moda se sedimenta un consabido según el cual lo central en torno a la problemática del vestido es el modo en que se expanden las tendencias. La moda, de esta manera, queda circunscrita dentro del problema del consumo y de una serie de cuestiones aledañas que orbitan en torno de dicha problemática. El cuerpo, por otra parte, permanece a la manera de un núcleo no problematizado pero que no obstante tiene una serie de efectos discursivos dentro de la comprensión social de la moda.

La ausencia de una reflexión en torno al cuerpo en las teorías sobre el vestido, no se da, en este sentido, a la manera de un silencio. El cuerpo, dentro de dichas teorías, es por el contrario continuamente evocado. Las filosofías de la moda no se detienen a conceptualizar el cuerpo porque lo consideran un reducto natural que se opone al carácter eminentemente sociocultural de la moda, pero eso no quiere decir que ese cuerpo 
entendido como naturaleza no tenga una función en el orden del discurso y la política. De hecho, mediante esta asimilación del cuerpo a la naturaleza y de la vestimenta a la cultura es que la moda, según lo he sostenido en el capítulo 2, despliega sus argucias. La moda, en tanto práctica de poder contribuye así a producir unos cuerpos que finge limitarse a ornamentar. En efecto, a través de algunas metáforas que evocan a la naturaleza y a las luchas evolutivas de la especie, lo corporal aparece como una superficie anterior a lo social que la cultura viene recubrir mediante el vestido. La desnudez, asimilada a la naturaleza, surge así como un constructo que legitima la manipulación cultural del cuerpo.

No obstante, la premisa de la desnudez como naturaleza resulta problemática, toda vez que la naturaleza del cuerpo requiere en sí misma de una enunciación cultural. En esa medida, tal y como lo señala Agamben, la desnudez constituye un dispositivo discursivo. Desde esta perspectiva, la desnudez carece de consistencia ontológica y los límites del cuerpo devienen bastante más lábiles que lo supuesto por el sentido común; las sintaxis corporales, asimismo, se develan como artificios gestionados socialmente. De esta forma, las distintas teorías de la moda estudiadas en la primera parte de este escrito resultan hasta cierto punto truculentas: tras sus afanes explicatorios respecto del origen de los vestidos, del simbolismo de los mismos, o de las dinámicas de consumo a partir de las cuales se difunden las tendencias, los teóricos del vestido -con excepción de Bourdieu, quien como lo he señalado ya se ocupa del tema, si bien preocupado por explicar sobre todo la lógica de los consumos culturales- parecieran no advertir la dimensión problemática del cuerpo y el hecho de que este y las prendas establecen una indisoluble unidad fenomenológica.

Interrogar la moda en busca de lo corporal, por tanto, ha implicado en la presente investigación dos operaciones distintas aunque ciertamente análogas e inseparables una de la otra. Por un lado, ha sido necesario pensar el lugar del cuerpo dentro de unas teorías que ciertamente parecían presuponerlo (capítulos 1 y 2). Pero por otro, se ha impuesto la necesidad de vincular ese silencio aparente con las relaciones de hecho que tienen el cuerpo y la vestimenta en la vida social (capítulos 3 y 4). A partir de estas dos 
indagaciones la relación entre cuerpo y vestimenta se ha revelado como una relación de suyo problemática. De hecho, lo que parecía ser en primera instancia una especie de faltante teórico, resultó a la postre una omisión funcional a la moda en tanto institución de la cual irradian relaciones de poder. A saber: el cuerpo presupuesto de los discursos teóricos de la moda forma parte de una episteme dentro de la cual la moda funciona como un enclave de diversos dispositivos de poder.

Dichos dispositivos fueron los que ocuparon mi atención en la segunda parte del trabajo (capítulos 3 y 4). Si la moda no se limita a cubrir los cuerpos sino que contribuye a producirlos performativamente, en definitiva, la vestimenta ejerce un poder. Según mi interpretación foucaultiana de la moda, dicho poder se despliega fundamentalmente en dos planos. Por una parte, la moda en/viste los cuerpos individuales a la manera de una disciplina -es el tema del capítulo 3-. En este plano, el atavío se presenta como un mecanismo microfísico que ejerce presiones, tornea morfologías y configura organismos. Por otra parte, la moda opera como un recurso de gobierno de las poblaciones en su relación con el espacio -tema en torno al cual gira el capítulo 4-. Es decir: la moda posee un costado biopolítico a partir del cual se modulan capacidades de acción -procedimiento al cual denominé dispositivo ceremonial-, se restringen y permiten accesos -a lo cual llamé dispositivo espacial-y se administran interacciones -procedimiento que designé con la categoría de dispositivo interaccional-. Estos dos planos en los cuales la moda pone a funcionar sus artimañas -el plano disciplinario discutido en el capítulo 3 y el biopolítico abordado en el capítulo 4- poseen, sin duda, diversos grados de complementariedad y se tensionan, refuerzan y articulan de diversos modos según las épocas. No obstante, un denominador común de ambas formas de poder a lo largo de la historia es su apelación al género.

Al examinar el cuerpo "natural" presupuesto por los teóricos de la moda, en efecto, resultó que se trataba de un cuerpo sexuado de antemano. Esto es: el cuerpo que las modas supuestamente se limitaban a cubrir parecía estar caracterizado a priori como un cuerpo con género. A la hora de pensar las relaciones de poder involucradas en la moda, la relación entre la vestimenta y el binarismo sexual cobró así de nuevo protagonismo en 
la presente investigación: tanto la dimensión disciplinaria como la dimensión biopolítica propias de la moda se revelaron, de hecho, como mecanismos dependientes $-\mathrm{y}$ simultáneamente productores- del binarismo sexual. La moda, en tanto disciplina, establece como objeto primario la producción de los géneros -géneros que, valga recordarlo, no se producen únicamente mediante el vestido-, mientras que la biopolítica vestimentaria, por su parte, regula interacciones, tránsitos y acciones con base en ese mismo género que el vestido produce performativamente. Si bien es cierto el vestido no es el único dispositivo destinado a la producción de los géneros (pues como lo señala Butler estos son construidos mediante toda una maquinaria social que abarca discursos, prácticas y artilugios materiales de diversa índole), también es cierto que la indumentaria se mantiene a lo largo de las épocas como un importante recurso material de gobierno y como un dispositivo sumamente eficaz debido al alto grado de naturalización con el que se portan socialmente los vestidos.

En razón de lo anterior, a la hora de analizar las grietas de la moda en tanto mecanismo de poder en la tercera y última parte del presente trabajo, el binarismo de género no podía sino ocupar, de nuevo, un lugar destacado. En otras palabras, dado que la moda disciplina los cuerpos en una clave genérica y que, a partir de la dicotomía de los géneros surgen otras formas de poder vestimentario, al analizar las posibilidades subversivas de la ropa opté por centrarme en la crítica al binarismo sexual. De esta forma, si por moda entendí a lo largo de este estudio el conjunto de relaciones de poder desplegado en torno al cuerpo -a lo cual me he referido en el título de este trabajo con la expresión "artimañas de la moda"-, el estilo apareció en la tercera parte de mi investigación como una posibilidad crítica a partir de la cual el cuerpo podría ser capaz de desviar las normativas vestimentarias. Ese desplazamiento de un uso disciplinado del vestido -lo que en términos generales designé en mi trabajo con el nombre de moda- a una utilización más crítica del mismo -a la cual hice referencia en términos de estilo- estaría marcado, según he argumentado, por un trabajo ético y político sobre y con el propio cuerpo que cuestiona las políticas regulatorias del aspecto y la presentación corporal. En particular, y dado el sitio estratégico que según mi trabajo el género ocupa en relación con el poder vestimentario, los estilos estudiados en la última parte de la presente investigación 
involucran una relación con el vestido y el propio cuerpo en la que el género y las política regulatorias del mismo son puestas en entredicho. Así, si la moda, en tanto mecanismo de poder, apunta a soldar los cuerpos con los sexos, y a derivar de allí una serie de comportamientos y actitudes sociales -en cuenta las relacionadas con la sexualidad y el deseo-, el estilo, tal y como lo definí en el capítulo 5, plantea formas de cuestionar y/o eclosionar esa continuidad entre cuerpo, género, sexualidad y comportamiento moral. El estilo, en este sentido, se presenta como una oportunidad para establecer modos de relacionamiento alternativos a partir del propio cuerpo, y por lo tanto, como una posibilidad a la hora de realizar ejercicios de subjetivación -0 , en su defecto, de desubjetivación- que no se limiten a desacatar las normas vestimentarias, sino que alcancen a poner dichas mismas normas en cuestión.

En el capítulo 6 intenté interpretar en esta línea algunos ejercicios de estilo. Así, el dandismo apareció en este nuevo contexto de lectura no ya únicamente como un movimiento literario o como una revuelta de clase (aunque ciertamente el dandismo es también esas dos cosas), sino como una forma de crítica vinculada al cuestionamiento de la masculinidad -especialmente la decimonónica- y como un trabajo ético pensado en tanto forma "aletúrgica" de emplear la vestimenta. Del mismo modo, quise interpretar el feminismo, allende su naturaleza teórica, como un ejercicio de crítica corporal relacionado al empoderamiento y a la crítica de las políticas regulatorias del cuerpo femenino. En el capítulo 7, por último, realicé un procedimiento teórico ligeramente diferente en torno al fenómeno andrógino. Si dandismo y feminismo constituyen dos matrices estilísticas históricamente detectables y altamente configuradas, la androginia en cambio constituye una suerte de estilo en ciernes cuyas huellas históricas parecieran más difusas. Por ello, me aboqué a conceptualizar la androginia allende su dimensión mítica para pensarla en relación con una crítica vestimentaria no ya de uno u otro polo del binarismo sexual, sino del núcleo binario mismo. Lo que habría en juego tras estos brotes estilísticos andróginos sería, pues, la posibilidad de un empleo estilizado de las prendas más allá de la dicotomía de los sexos. En tal sentido, la androginia vendría a ser una especie de enclave estilístico rico en términos de un porvenir. 
La indagación a propósito de la dimensión corporal propia de la moda, me ha llevado, por lo tanto, a tematizar una forma de poder hasta cierto punto inadvertida (me refiero al biopoder vestimentario), así como a analizar las posibilidades éticas y políticas de un uso crítico de la vestimenta (reflexión que he articulado en torno a la noción de estilo). Se trata de un recorrido en el que si bien he querido mostrar cierta vocación disciplinaria de la moda, no he querido cerrar el paso a la posibilidad de un uso políticamente abierto de la indumentaria. De hecho, como lo señala Foucault, toda disputa política en torno al cuerpo debería pensarse como indefinida, dadas las múltiples apropiaciones posibles de las cuales son susceptibles las normas en general y las normas corporales en particular (Foucault, [1975] 1992, 112-113). En tal sentido, si el vestido es un dispositivo de gobierno de los cuerpos y los placeres, no está de más una actitud políticamente atenta a las posibilidades que dicho dispositivo ofrece en términos de la crítica. Mostrar esta compleja relación del vestido con el cuerpo y el poder -relación que es al mismo tiempo de sujeción y de habilitación-, así como detectar el modo en que esa relación ha quedado subordinada teóricamente hablando dentro una tradición de estudios sobre el vestido unilateralmente interesada en el problema de la difusión de la tendencias ha sido, en última instancia, el objetivo de mi investigación. En otras palabras, este trabajo ha querido confrontar un enfoque tradicional sobre el fenómeno del vestido en aras de iluminar algunos de sus costados problemáticos menos visitados.

No obstante, otro interés subyace al objetivo recién descrito: se trata de mostrar hasta qué punto una serie de relaciones de violencia tienen lugar alrededor de los cuerpos con género, especialmente de aquellos que no se atienen a las normas, o bien de aquellos para los cuales las normas no fueron pensados. En efecto, si los géneros son resultado de una serie de dispositivos de poder que, como la moda, pretenden marcar las capacidades y posibilidades de acción y movimiento del cuerpo, esto es, si los géneros surgen como resultado de clasificaciones ontológicas con consecuencias sociales, entonces el problema de la vestimenta es algo más que un fenómeno frívolo asociado con el encantamiento y el gusto por el despilfarro. En torno a la moda, desde esta perspectiva, se llevan a cabo, por el contrario, una serie de ejercicios de violencia física y simbólica que se encuentran bien disimulados por efecto de unas teorías clásicas ciertamente miopes con respecto a las 
consecuencias culturales del fenómeno en cuestión (especialmente para aquellas consecuencias que atañen a las mujeres o a otros cuerpos socialmente marcados para su discriminación). El disciplinamiento de género involucrado en la moda, desde esta perspectiva, aparece soslayado en la mayor parte de la teoría toda vez que se trata de miradas que no padecen dicho disciplinamiento, o aún más, que ni siquiera se interesan en registrarlo. Por mi parte, considero con Laqueur que "el hecho de que el dolor y la injusticia tengan género y correspondan a signos corporales (...) confiere importancia a una consideración sobre la construcción del sexo" ([1990], 1994, 41). En este caso, dicha construcción, ligada teóricamente al tema de la indumentaria, pretende, así, volver políticamente relevante una práctica de violencia que, debido a su presencia cotidiana, pasa la mayor parte del tiempo inadvertida. Pero no se trataría solo de decodificar el poder vestimentario con todo y sus efectos en el cuerpo, sino también de evidenciar que dicho poder, dado su carácter contingente, está plagado de zonas en las que las insurrecciones corporales son de hecho posibles. 


\section{Bibliografía}

About, I y Denis, V. ([2010] 2011). Historia de la identificación de las personas (Trad. A. Herrera). Barcelona: Ariel.

Agamben, G. ([1999] 2011). Desnudez (Trads. M. Ruvituso y M. T. D’Meza). Buenos Aires: Adriana Hidalgo.

Amícola, J. (2000). Camp y posvanguardia. Manifestaciones culturales de un siglo fenecido. Buenos Aires: Paidós.

Bach, A.M., Femenías, M.L. y Roulet, M. (1994). Las apariencias engañan: metáforas filosóficas. En M.I. Santa Cruz, A.M. Bach, M.L. Femenías, A. Gianella y M. Roulet (Comps.) Mujeres y filosofía (II). Teoría filosófica de género (pp. 184193). Buenos Aires: Centro Editor de América Latina.

Balzac, H. ([1830] 1998). Fisiología del vestir (Trad. P. Brines). En Dime cómo andas, te drogas, vistes y comes... y te diré quién eres (pp. 125-144). Barcelona: Tusquets. . ([1833] 1998). Teoría del andar (Trad. P. Brines). En Dime cómo andas, te drogas, vistes y comes... y te diré quién eres (pp. 11-87). Barcelona: Tusquets.

Bard, C. ([2010] 2012). Historia política del pantalón (Trad. N. Viver). Buenos Aires: Tusquets.

Barthes, R. ([1957] 2003). Historia y sociología del vestido (Trad. C. Roche). En El sistema de la moda y otros escritos (pp. 11-346). Barcelona: Paidós. . ([1959] 2003). "Lenguaje y vestido" (Trad. C. Roche). En El sistema de la moda y otros escritos (pp. 363-374). Barcelona: Paidós. . ([1960] 2003). “El azul está de moda este año”. Notas sobre la investigación de las unidades significantes en el vestido de moda (Trad. C. Roche). En El sistema de la moda y otros escritos (pp. 379-395). Barcelona: Paidós. . ([1962] 2003). El dandismo y la moda (Trad. C. Roche). En El sistema de la moda y otros escritos (pp. 403-408). Barcelona: Paidós. . ([1967] 2003a). El sistema de la moda (Trad. C. Roche). En El sistema de la moda y otros escritos (pp. 11-346). Barcelona: Paidós. 
. ([1967] 2003b). Sobre El sistema de la moda (Trad. C. Roche). En El sistema de la moda y otros escritos (pp. 427-432). Barcelona: Paidós.

Baudelaire, Ch. ([1862] 1995). El pintor en la vida moderna (Trad. A. Saavedra). Murcia: Arquilectura.

Baudot, F. (2001). Moda y surrealismo (Trad. P. Manchot). Madrid: H Kliczkowski.

Baudrillard, J. ([1968] 2007). El sistema de los objetos (Trad. F. González Aramburu). México D.F.: Siglo XXI. . ([1976] 1980). El intercambio simbólico y la muerte (Trad. C. Rada). Caracas:

Monte Ávila Editores.

Beauvoir, S. ([1949] 1987). El segundo sexo. Buenos Aires: Siglo Veinte.

Becker, H. ([1963] 2012). Outsiders: hacia una sociología de la desviación (Trad. J. Arrambide). Buenos Aires: Siglo XXI.

Benjamin, W. ([1974] 2012). El París de Baudelaire (Trad. M. Dimópulos). Buenos Aires: Eterna Cadencia.

Berman, M. ([1982] 1988). Todo lo sólido se desvanece en el aire (Trad. A. Morales). Buenos Aires: Siglo XXI.

Bordo, S. (1993). Unbearable Weight. Feminism, Western Culture, and the body. Berkeley: Universitiy of California Press.

Bourdieu, P. ([1979] 2012). La distinción. Criterio y bases sociales del gusto (Trad. M. del C. Ruiz). Madrid: Taurus. . (2011). El sentido social del gusto (Trad. A.B. Gutiérrez). Buenos Aires: Siglo XXI.

Butler, J. ([1986] 1998). Sexo y género en El segundo sexo de Simone de Beauvoir (Trad. L. Zadorojny). Revista Mora, $N^{\circ} 4$, pp. 10-21. . ([1987] 2012). Sujetos del deseo. Reflexiones hegelianas en la Francia del siglo XX (Trad. E. Luján). Buenos Aires: Amorrortu. . ([1990] 1998). Actos performativos y constitución del género: un ensayo sobre fenomenología feminista (Trad. M. Lourties). Debate feminista, \#18, 296-314. . ([1990] 2007). El género en disputa. El feminismo y la subversión de la identidad (Trad. M. A. Muñoz). Barcelona: Paidós. 
. ([1991] 2000). Imitación e insubordinación de género (Trad. T.M.U). Revista de Occidente, \#235, 85-109.

- ([1993] 2008). Cuerpos que importan: sobre los límites materiales y discursivos del "sexo" (Trad. A. Bixio). Buenos Aires: Paidós.

. ([1997] 2004). Lenguaje, poder e identidad (Trad. J. Sáez y B. Preciado).

Madrid: Síntesis.

. (2000). Appearances Aside. California Law Review, 88, pp 55-63.

. ([2002] 2011). ¿Qué es la crítica? Un ensayo sobre la virtud de Foucault

(Trad. M. Expósito). EIPCP web site. Disponible en: http://eipcp.net/ transversal/0806/butler/es

. ([2004] 2006). Deshacer el género (Trad. P. Soley). Barcelona: Paidós.

- ([2005] 2009). Dar cuenta de sí mismo. Violencia ética y responsabilidad (Trad. H. Pons). Buenos Aires: Amorrortu.

Butler, J., Laclau, E. y Žižek, S. ([2000] 2011). Contingencia, hegemonía, universalidad (Trad. C. Sardoy y G. Homs) . Buenos Aires: Fondo de Cultura Económica.

Cagnolati, Beatriz y Femenías, María Luisa. (Comps.) (2010). Simone de Beauvoir, las encrucijadas de "el otro sexo". La Plata: Editorial de la Universidad Nacional de La Plata.

Calderón J.G. (2004). Roth-Williams, principios y objetivos. Ortodoncia actual, pp. 6-10.

Calefato, P. (2001). El cuerpo vestido, los sentidos y la escritura: entre la moda y el cine. DeSignis, 1, 213-224.

. (2007). Mass moda. Actas del Curso Traje, identidad y sujeto en el arte contemporáneo. Madrid, 10 de enero al 7 de febrero, pp. 32-37.

Camus, A. ([1951] 2008). El hombre rebelde (Trad. L. Echávarri). Buenos Aires: Losada.

Carlyle, T. ([1835) 1945). Sartor Resartus (Trad. J. Ojeda). Buenos Aires: Emecé.

Castellanos, G. (2006). Sexo, género y feminismos: tres categorías en pugna. Cali: Universidad del Valle.

Castro, E. (2011). Diccionario Foucault: temas, conceptos y autores. Buenos Aires: Siglo XXI.

Clarke, J. (2006). Style. En S. Hall y T. Jefferson (Eds.) Resistance through Rituals: Youth subcultures in post-war Britian (pp. 147-161). New York: Routledge. 
Clarke, Hall, Jefferson y Roberts. (2006). Subcultures, cultures and class. En S. Hall y T. Jefferson (Eds.) Resistance through Rituals: Youth subcultures in post-war Britian (pp. 3-59). New York: Routledge.

Córdoba, M. (2010) La cirugía estética en la prensa gráfica: entre la información y la seducción. DeSignis, 16, 58-66.

Corominas, J. (1961). Breve diccionario etimológico de la lengua castellana. Madrid: Gredos.

Corrigan, P. y Frith, S. (2006). The Politics of Youth Culture. En S. Hall y T Jefferson Resistance through Rituals: Youth subcultures in post-war Britian (pp. 195-204). New York: Routledge.

Cuvardic, D. (2009). La reflexión sobre el flâneur y la flanerie en los escritores modernistas latinoamericanos. Káñina, XXXIII (1), 21-35.

Darwin, Ch. ([1859] 2010). On the Origin of Species by Means of Natural Selection. Inglaterra: Cricket House Books.

D'Aurevilly, J. B. ([1845] 2008). Del dandismo y de George Brummell (Trad. J. Salvetti). Buenos Aires: Selecciones de Amadeo Mandarino.

De Lauretis, T. ([1989] 1996). La tecnología del género. Mora, $n^{\circ}$ 2, p. 8.

Deleuze, G. y Guattari, F. ([1972] 1985). El antiedipo. Capitalismo y esquizofrenia (Trad. F. Monge). Barcelona: Paidós.

Deleuze, G. ([1986] 1999). La vida como obra de arte (Trad. J. L. Pardo). En Conversaciones (153-164). Valencia: Pretextos.

- ([1990] 1999). Post-scriptum sobre las sociedades de control. En Conversaciones (Trad. J. L. Pardo). Valencia: Pretextos.

Durán, G. (2010). Dandysmo y contragénero. Murcia: Centro de Documentación y Estudios Avanzados de Arte Contemporáneo.

Echavarren, R. (2010). Arte andrógino: estilo vs moda. Montevideo: HUM.

Elias, N. ([1979] 2012). El proceso de la civilización (Trad. R. García). México: Fondo de Cultura Económica.

Entwistle, J. ([2000] 2002). El cuerpo y la moda: una visión sociológica (Trad. A. Sánchez). Barcelona: Paidós. 
Erner, G. ([2005] 2010). Víctimas de la moda. Cómo se crea, porqué la seguimos (Trad. I. Urrea y M. Camps). Barcelona: Gustavo Gili.

Esposito, R. ([2004] 2011). Bíos. Biopolítica y filosofia (Trad. C. Molinari). Buenos Aires: Amorrortu.

Feixa, C. (1999). De jóvenes, bandas y tribus. Antropología de la juventud. Barcelona: Ariel.

Femenías, M.L. (1999). La metáfora en Aristóteles. Buenos Aires: Subsecretaría de Publicaciones de la Facultad de Filosofía y Letras de la Universidad de Buenos Aires. . (2001). Condensación y analogía: dos claves en la metáfora aristotélica. En H. Berinstáin (Comp.), El horizonte interdisciplinario de la retórica (pp. 65-78). México: UNAM. . (2003). Judith Butler: introducción a su lectura. Buenos Aires: Catálogos. . (2007). El género del multiculturalismo. Bernal: Universidad Nacional de Quilmes.

. (2012). Sobre sujeto y género: re-lecturas feministas desde Beauvoir a Butler. Rosario: Prohistoria.

Firestone, S. ([1973] 1976). La dialéctica del sexo (Trad. R. Ribé). Barcelona: Kairós.

Flügel, J.C. ([1930] 1964). Psicología del vestido (Trad. A. Kornblit). Buenos Aires: Paidós.

Foucault, M. ([1963] 2008). El nacimiento de la clínica (Trad. F. Perujo). Buenos Aires: Siglo XXI. . ([1964a] 2010). Historia de la locura en la época clásica (1er tomo, Trad. J. J. Utrilla). Buenos Aires: Fondo de cultura Económica. . ([1964b] 2010). Historia de la locura en la época clásica (2do tomo, Trad. J. J. Utrilla). Buenos Aires: Fondo de cultura Económica. - ([1966] 2002). Las palabras y las cosas (Trad. E. C. Frost). Buenos Aires: Siglo XXI. . ([1969] 2007). La arqueología del saber (Trad. A. Garzón). México: Siglo XXI. 
. ([1971] 1992). Nietzsche, la genealogía, la historia. En Microfisica del poder (Trad. F. Álvarez y J. Varela) (pp. 7 -32). Madrid: Las Ediciones de la Piqueta.

. ([1975] 1992). Poder-cuerpo (Trad. J. Varela y F. Álvarez-Uría). Madrid:

Ediciones La Piqueta.

.([1975] 2008). Vigilar y castigar (Trad. A. Garzón). Buenos Aires: Fondo de Cultura Económica.

. ([1976] 2005). La voluntad de saber. Historia de la sexualidad, volumen 1. (Trad. U. Guiñazú). México: Siglo XXI.

. ([1977] 1991). El juego de Michel Foucault. En Saber y verdad (Trad. J. Varela y F. Álvarez-Uría) (127-162). Madrid: Ediciones La Piqueta.

- ([1978] 2010). La evolución del concepto de individuo peligroso en la psiquiatría legal del siglo XIX. En Obras esenciales (Trad. A. Gabilondo) (719738). Barcelona: Paidós.

. ([1980] 2007). Herculine Barbin llamada Alexina B (Trad. A. Serrano y A. Canellas). Madrid: Talasa.

- ([1983] 2013). Acerca de la genealogía de la ética: un panorama del trabajo en curso. En La inquietud por la verdad: escritos sobre la sexualidad y el sujeto (Trad. H. Pons). Buenos Aires: Siglo XXI.

. ([1984] 2003). El uso de los placeres (Trad. M. Soler). México: Siglo XXI. . ([1984] 2004). La inquietud de sí (Trad. T. Segovia). México: Siglo XXI.

- ([1984] 2010a). La ética del cuidado de sí como práctica de la libertad. En Obras esenciales (Trad. A. Gabilondo) (pp. 1017-1026). Barcelona: Paidós.

. ([1984] 2010b). El retorno de la moral. En Obras esenciales (Trad. A. Gabilondo) (pp. 1027-1046). Barcelona: Paidós.

. ([1984] 2010c). ¿Qué es la ilustración? En Obras esenciales (Trad. A. Gabilondo) (pp. 975-990). Barcelona: Paidós.

. ([1988] 2008). Tecnologías del yo. En Tecnologías del yo y otros textos afines (Trad. M. Allendesalzar). Buenos Aires: Paidós.

. ([1990] 1995). ¿Qué es la crítica? [crítica y Aufklärung] (Trad. J. de la Higuera). Daimon: Revista de Filosofia de la Universidad de Murcia, No 11, 526. 
. ([1994] 2010). Espacios diferentes (Trad. V. Goldstein). En M. Foucault, El cuerpo utópico. Las Heterotopías (63-83). Buenos Aires: Nueva Visión.

. ([1997] 2010). Defender la sociedad (Trad. H. Pons). Buenos Aires: Fondo de Cultura Económica.

- ([1999] 2002). Los anormales (Trad. H. Pons). Buenos Aires: Fondo de Cultura Económica.

. ([2001] 2009). La hermenéutica del sujeto (Trad. H. Pons). Buenos Aires: Fondo de Cultura Económica.

. ([2003] 2008). El poder psiquiátrico (Trad. H. Pons). Buenos Aires: Fondo de Cultura Económica.

. ([2004] 2010). El nacimiento de la biopolítica (Trad. H. Pons). Buenos Aires: Fondo de Cultura Económica.

. ([2004] 2009). Seguridad, territorio y población (Trad. H. Pons). Buenos Aires: Fondo de Cultura Económica.

. ([2008] 2009). Una lectura de Kant: introducción a la antropología en sentido pragmático (Trad. A. Dilon). Buenos Aires: Siglo XXI.

. ([2008] 2010). El gobierno de sí y de los otros (Trad. H. Pons). Buenos Aires: Fondo de Cultura Económica.

. ([2009] 2010a). El coraje de la verdad (Trad. H. Pons). Buenos Aires: Fondo de Cultura Económica.

. ([2009] 2010b). El cuerpo utópico (Trad. V. Goldstein). En M. Foucault, El cuerpo utópico. Las Heterotopías (7-18). Buenos Aires: Nueva Visión.

Freud, S. ([1905] 2013). Tres ensayos de teoría sexual (Trad. L. López-Ballesteros). En S. Freud, Obras completas (1169-1237), Vol. XIX. Buenos Aires: Siglo XXI. . ([1920] 2013). Más allá del principio del placer (Trad. L. López-Ballesteros). En S. Freud, Obras completas (2507-2541), Vol. XVIII. Buenos Aires: Siglo XXI.

Gatens, M. y Mackinnon, A. (Eds.). (1998). Gender and institutions. Inglaterra: Cambridge Univeristy Press.

Gavarrón, L (1997). Piel de ángel. Historias de la ropa interior femenina. Barcelona: Tusquets. 
Gioscia, L. (2008). El cuerpo y sus descontentos. En T. Porzecanski (Comp.), El cuerpo y sus espejos. Estudios antropológico-culturales (277-286). Montevideo: Planeta.

Gispert, C. (1997). Diccionario de Medicina Océano Mosby. Barcelona: Océano.

Godart, F. ([2010] 2012). Sociología de la moda (Trad. A. Díaz). Buenos Aires: Edhasa.

Goffman, E. ([1963] 2010). Estigma. La identidad deteriorada (Trad. L. Guinsberg). Buenos Aires: Amorrortu.

Guthrie, W.K.C. ([1962] 1990). Historia de la filosofía griega. Vol. IV. Platón y sus diálogos: primera época (Trads. A. Vallejo y A. Medina). Madrid: Gredos.

Hall, S y Jefferson, T. (2006). Once more Resistance through Rituals. En S. Hall y T Jefferson Resistance through Rituals: Youth subcultures in post-war Britian (pp. i-xxxii). New York: Routledge.

Halperlin, D. ([1995] 2007). San Foucault. Para una hagiografía gay (Trad. Mariano Serrichio). Córdoba: Ediciones literales.

Haraway, D. ([1991] 1995). Ciencia, cyborgs y mujeres. La reinvención de la naturaleza (Trad. M. Talens). Madrid: Cátedra.

Hardt, M y Negri, A. ([2000] 2006). Imperio (Trad. A. Bixio). Buenos Aires: Paidós.

Heath, J y Potter, A. ([2004] 2005). Rebelarse vende. El negocio de la contracultura (Trad. G. Bustelo). Bogotá: Taurus.

Hegel, G.W.F. ([1807] 2009). Fenomenología del espiritu (Trad. W. Roces). Buenos Aires: Fondo de Cultura Económica. . ([1842] 1983). Estética 2 (Trad. A. Llanos). Buenos Aires: Ediciones Siglo Veintiuno.

Hernando, A. (2012). La fantasía de la individualidad. Sobre la construcción sociohistórica del sujeto moderno. Buenos Aires: Katz.

Hocquenghem, G. ([2000] 2009). El deseo homosexual (con Terror anal de Beatriz Preciado) (Trad. G. Huard). España: Merlusina.

Irigaray, L. ([1974] 1978). Speculum. Espéculo de la otra mujer (Trad. A. Baralides). Madrid: Saltés.

Jiménez, J. (1996). De Platón a Michael Jackson. Entresijos del imaginario andrógino. Revista de filosofía de la Universidad de Costa Rica, No XXXIV, 227-236.

Johnson, K., Hegland, J. y Schofield, N. (1999). Survivors of Rape: Functions and 
Implications of Dress in a Context of Coercitive Power. En K. Johnson y S. Lennon (Eds.), Appearance and Power (pp. 11-32). Oxford/Nueva York: Berg.

Kaiser, S. (2001). Minding Appearances: Style, Truth and Subjectivity. En J. Entwistle y E. Wilson (Eds.), Boddy Dressing: Dress, Body, Culture (79-102). Oxford/Nueva York: Berg.

Kant, I. ([1786] 2010). Probable inicio de la historia humana (Trads. R. Rodríguez y C. Roldán). En I Kant, Ideas para una historia universal en clave cosmopolita y otros escritos sobre Filosofía de la Historia [Versión Kindle] (109-123). Extraído de Amazon.com.

. ([1790] 1961). Crítica del juicio (Trad. J. Rovira). Buenos Aires: Losada.

Klein, N. ([2000] 2007). No Logo (Trad. A. Jock1). Barcelona: Paidós.

König, R. ([1958] 1968). Sociología de la moda (Trad. A.M. Uribe). Buenos Aires: Carlos Lohlé.

Kristeva, J. ([1969] 2001). Semiótica 1 (Trad. J.M Arancibia). Madrid: Fundamentos. . ([1980) 2006). Poderes de la perversión (Trad. N. Rosa y V. Ackerman). México: Siglo XXI.

Lakoff y Johnson. ([1980] 1986). Metáforas de la vida cotidiana (Trad. C. González Marín). Madrid: Cátedra.

Laqueur, T. ([1990] 1994). La construcción del sexo. Cuerpo y género desde los griegos hasta Freud (Trad. E. Portela). Madrid: Cátedra.

Laver, J. ([1982] 2008). Breve historia del traje y de la moda (Trad. E. Albizua). Madrid: Cátedra.

Le Breton, D. ([1992] 2011). La sociología del cuerpo. Buenos Aires: Nueva Visión.

Libis, J. ([1980] 2001). El mito del andrógino (Trads. M. Tabuyo y A. López). Madrid: Siruela.

Lipovetsky, G. ([1987] 2009). El imperio de lo efímero (Trad. F. Hernández y C. López). Barcelona: Anagrama.

Lloyd G. E. R. (1968). The Role of Medical and Biological Analogies in Aristotle's Ethics. Phronesis, 13, Vol. 13, No. 1, pp. 68-83.

Lozano, J. (2000). Simmel: la moda, el atractivo formal del límite. Reis, 89, 237-250. 
. (2007). La moda, metrónomo de la cultura. Entrevista a Jorge Lozano por

Pablo Pérez. Punto de vista. Revista de Cultura, XXX, \# 89, 21-26.

Lurie, A. ([1981] 2009). El lenguaje de la moda: una interpretación de las formas de vestir (Trad. F. Inglés). Barcelona: Paidós.

Malabou, C. (2010). La plasticidad en espera (Trad. C. Durán y M. Valdivia). Santiago de Chile: Palinodia.

Marí, E. (2001). El banquete de Platón: el eros, el vino, los discursos. Buenos Aires: Biblos.

Martínez Barreiro, A. (2006). La difusión de la moda en la era de la globalización. Papers, 81, 187-204.

Merchant, C. (2006). The Scientific Revolution and The Death of Nature. Isis, \#97, 513533.

Merleau-Ponty, M. ([1945] 2000). Fenomenología de la percepción (Trad. J Cabanes). Barcelona: Ediciones Península.

Monneyron, F. ([2005] 2006). 50 respuestas sobre la moda (Trad. C. Zelich). Barcelona: Gustavo Gili.

Nancy, J-L. ([2000] 2007). El intruso (Trad. M. Martínez). Buenos Aires: Amorrortu. . ([2000] 2010). Corpus (Trad. P. Bulnes). Madrid: Arena Libros.

Olsen, F. ([1990] 2013). El sexo del derecho (Trad. M. Santoro y C. Courtis). Instituto de Derechos Humanos de la UNLP web site. Disponible en: http://www.derechoshumanos.unlp.edu.ar/assets/files/documentos/el-sexo-delderecho.pdf

Paglia, C. ([1994] 2006). Sexual Personae: arte y decadencia desde Nefertiti a Emily Dickinson (Trad. P. Vázquez). Madrid: Valdemar.

Parkins, W. (2002a). (Ad)dressing Citizens. En W. Parkins (Ed.), Fashioning the Body Politic. Oxford/Nueva York: Berg. . (2002b). "The Epidemic of Purple, White and Green": Fashion and the Suffragette Movement in Britain 1908-1914. En W. Parkins (Ed.), Fashioning the Body Politic. Oxford/Nueva York: Berg. . (2009). Protesting like a Girl: Embodiment, Dissent and Feminist Agency. Feminist Theory 2000; 1; 59, 59-78. 
Pastoureau, M. ([1991] 2005). Las vestiduras del diablo. Breve historia de las rayas en la indumentaria (Trads. M. Oliver y A. Sunyer). Barcelona: Océano.

Pearson, G. y Twohig, J. (2006). Ethnography through the Looking-Glass. En S. Hall y T. Jefferson (Eds.) Resistance through Rituals: Youth subcultures in post-war Britian (pp. 100-105). New York: Routledge.

Platón. ([389 a.C] 1986). Banquete (Trad. M. Martínez). En Platón, Diálogos III (43287). Madrid: Gredos.

Preciado, B. (2008). Testo yonqui. Madrid: Espasa Calpe. . ([2000] 2011). Manifiesto contrasexual (Trad. J. Díaz y C. Meloni). Barcelona: Paidós.

Quijano, A. (2000). Colonialidad del poder y clasificación social. Journal of worldsystems research, vi, 2, summer/fall 2000, 342-386.

Reguillo Cruz, R. (2000). Emergencia de culturas juveniles. Estrategias del desencanto. Buenos Aires: Norma.

Retana, C. (2009). Las artimañas de la moda: la ética colonial/imperial y sus vínculos con el vestido moderno. Revista de Filosofía de la Universidad de Costa Rica, vol. 47, \#122, 87-96.

Rich, A. (1980). Compulsory Heterosexuality and Lesbian Existence. Signs: Journal of Women in Culture and Society, vol. 5, no 41, 631-660.

Rivière, M. (1977). La moda: ¿comunicación o incomunicación?. Barcelona: Gustavo Gili.

Root, R. (2002). Tailoring the Nation: Fashion Writing in Ninetheenth-Century Argentina. En W. Parkins (Ed.), Fashioning the Body Politic. Oxford/Nueva York: Berg.

Rousseau, J. J. ([1762] 2011). Emilio [version E-book]. Buenos Aires: Tecnibook.

Rowe, C. (1998). Il Simposio di Platone. Sankt Augustin: Academia Verlag.

Sabsay, L. (2011). Fronteras sexuales: espacio urbano, cuerpos y ciudadanía. Buenos Aires: Paidós.

Salvatore, D. ([2008] 2009). Filosofía del dandismo (Trad. G. Montes). Buenos Aires: Nueva Visión.

Sartre, J. P. ([1947] 1968). Baudelaire (Trad. A. Bernárdez). Buenos Aires: Losada. 
Saulquin, S. (2008). Historia de la moda argentina. Buenos Aires: Emecé. . (2010). La muerte de la moda, el día después. Buenos Aires: Paidós.

Sauvageot, C. y Menard, R. (2007). Vestidos y peinados en las civilizaciones antiguas. Buenos Aires: Quadrata.

Sibilia, P. (2010). El hombre posorgánico. Cuerpo, subjetividad y tecnologías digitales. Buenos Aires: Fondo de Cultura Económica.

Simmel, G. ([1908] 1998). El problema del estilo. Reis, 84, 319-326. .([1905] 2008). Filosofía de la moda. En De la esencia de la cultura (pp. 71-95). Buenos Aires: Prometeo. . ([1909] 2008). Filosofía de la coquetería. En De la esencia de la cultura (pp. 5371). Buenos Aires: Prometeo.

Simón, G. (2010). Narrativas sobre el cuerpo en semanarios de prensa gráfica. DeSignis, 16, 86-94. Buenos Aires: La Crujía.

Sirimarco, M. (2010). Desfiles, marchas, venias y saludos. El cuerpo como sujeto de conocimiento en la formación policial. En S. Citro (Coord.), Cuerpos plurales: antropología de y desde los cuerpos (189-202). Buenos Aires: Biblos.

Soch, D. (2010). Guaridas, bombas caseras, autolesiones y engaños diversos. Antidisciplina obrera y resistencia corporal en una industria automotriz transnacional. En S. Citro (Coord.), Cuerpos plurales: antropología de y desde los cuerpos (203-217). Buenos Aires: Biblos.

Sontag, S. ([2007] 2012). Notas sobre lo camp. En S. Sontag, Contra la interpretación y otros ensayos (Trads. H. Vásquez y M. Pessarrodona). Buenos Aires: Debolsillo.

Squicciarino, N. ([1986] 1998). El vestido habla: consideraciones psico-sociológicas sobre la indumentaria (Trad. J.L. Aja). Madrid: Cátedra.

Steimberg, O. (2001). Moda y estilo a partir de una frase de Walter Benjamin. DeSignis, 1, 29-39. Barcelona: Gedisa.

Sutherland, J.P. (2011). Cielo Dandy: escrituras y poéticas de estilo en América Latina. Buenos Aires: Eterna Cadencia.

Tseëlon, E. (2001). From Fashion to Masquerade: Towards an Ungendered Paradigm. En J. Entwistle y E. Wilson (Eds.), Boddy Dressing: Dress, Body, Culture (103-120). Oxford/Nueva York: Berg. 
Valdettaro, S. (2010). Más allá de Dolly y Michael Jackson. La moda del tecno-cuerpo: mutantes, clones y cyborgs. DeSignis, 16, 49-57.

Veblen, T. ([1899] 2005). Teoría de la clase ociosa (Trad. V. Herrero). México: Fondo de Cultura Económica.

Venes, D. ([2005] 2007). Diccionario enciclopédico Taber de ciencias de la salud. Madrid: Difusión Avances de Enfermería.

Vigarello, G. ([2001] 2005). Corregir el cuerpo. Historia de un poder pedagógico (Trad. H. Cardoso). Buenos Aires: Nueva Visión. - ([1999] 2006). Lo sano y lo malsano. Historia de las prácticas de la salud desde la Edad Media hasta nuestros días (Trad. A. Martínez). Madrid: Abada Editores.

. ([2004] 2009). Historia de la belleza. El cuerpo y el arte de embellecer desde el Renacimiento hasta nuestros días (Trad. H. Cardoso). Buenos Aires: Nueva Visión.

Volli, U. (2001). ¿Semiótica de la moda, semiótica del vestuario? DeSignis, 1, 57-68.

Weil, S. ([1951] 2010). La condición obrera (Trads. A. Dilon, J. Herrera y A. Jutglar). Buenos Aires: El Cuenco de Plata.

Weitbrecht, H.J. ([1968) 1978). Manual de psiquiatría (Trad. R. Echeverría). Madrid: Gredos.

Weltzien, F. (2005). Masque-ulinities: Changing Dress as a Display of Masculinity in the Superhero Genre. Fashion Theory, Volume 9, Issue 2, 229-250.

Wilde, O. ([1890] 1999). El retrato de Dorian Gray. Madrid: El Mundo.

Wilson, E. (2003). Adorned in dreams. Fashion and Modernity. Londres \& Nueva York: I.B. Tauris. . (2001). Moda y estudios culturales. Elizabeth Wilson entrevistada por Katie Lloyd Thomas y Guillermo Olivera. DeSignis, 1, 285-289.

Woolf, V. ([1930] 2007). Beau Brummel o el arte de hacerse la corbata a la perfección. El Malpensante, \#78. Disponible en: http://www.elmalpensante.com index.php?doc $=$ display . ([1938] 1999). Tres guineas (Trad. A. Bosch). España: Lumen. 
Wrigley, R. (2002). The Formation and Currency of a Vestimentary Stereotype: The Sans-culotte in Revolutionary France. En W. Parkins (Ed.), Fashioning the Body Politic. Oxford/Nueva York: Berg.

Yalom, M. (1997). Historia del pecho (Trad. A. Puigròs). Barcelona: Tusquets.

Yonnet, P. ([1985] 2005). Juegos, modas y masas (Trad. A. L. Bixio). Barcelona: Gedisa. 